
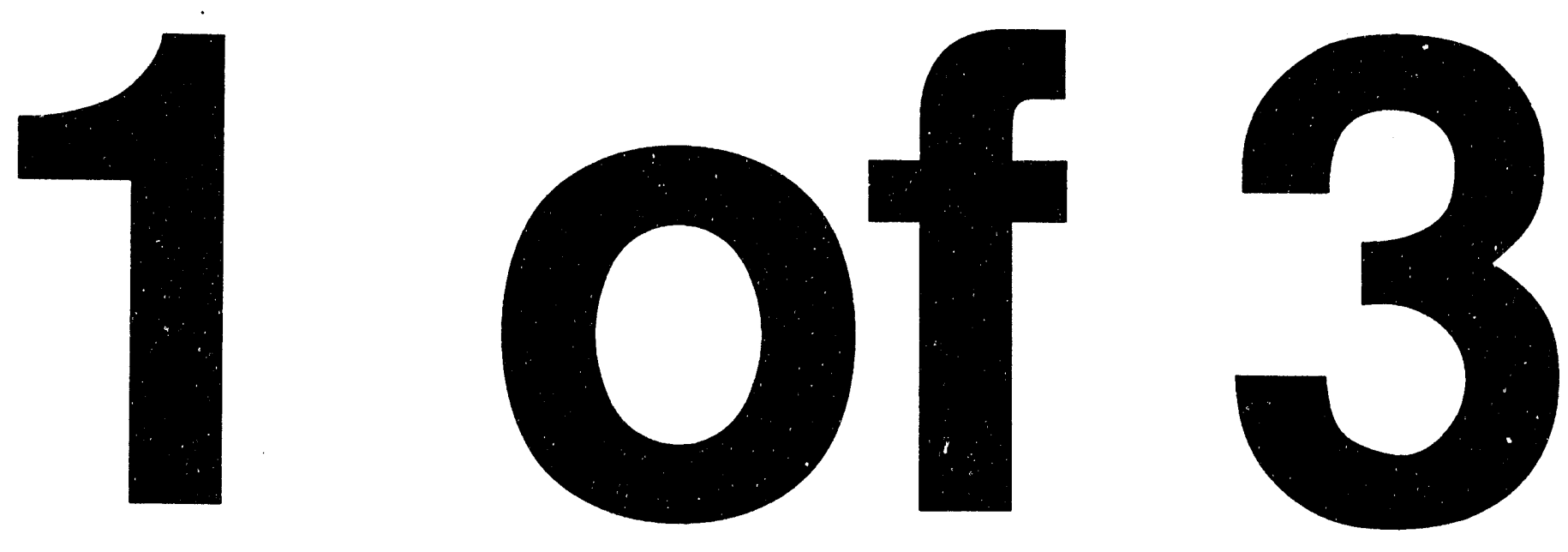


\section{CELLULAR RESPONSES TO ENVIRONMENTAL DNA DAMAGE}

IN HONOR OF THE 7OTH BIRTHDAY

OF DR. RICHARD B. SETLOW

Banff Springs Hotel

Banff, Alberta, Canada

December 1-6, 1991

Conference Co-Chairpersons

Philip C. Hanawalt

Stanford University

Stanford, CA
Malcolm C. Paterson

Cross Cancer Institute

- Edmonton, Alberta, Canada

\section{CONFERENCE SPONSORS}

U. S. Department of Energy

National Center for Toxicological Research Alberta Heritage Foundation for Medical Research

Alberta Cancer Board

ACIC (Canada)

Cross Cancer Institute

Procter \& Gamble Company

Oxigene, Inc.

Merck Sharp \& Dohme Research Laboratories 


\section{CELLULAR RESPONSES TO ENVIRONMENTAL DNA DAMAGE An AACR Special Conference in Cancer Research In Honor of the 70th Birthday of Dr. Richard B. Setlow \\ December 1-6, 1991 \\ Banff Springs Hotel, Banff, Alberta, Canada}

\section{Conference Co-Chairpersons}

\author{
Philip C. Hanawat \\ Stanford University \\ Stanford, CA
}

\author{
Malcolm C. Paterson \\ Cross Cancer Institute \\ Edmonton, Alberta, Canada
}

\section{PROGRAM}

(Locations of all sessions are listed; please note that the room for general sessions changes from the Van Home Ballroom BC to the Altambra Room as of Wechesday, Decomber 4. All meals will be served in the Aberta Dining Room.)
5:30 p.m. to 7:00 p.m.
7.00 p.m. to 0:00 p.m.
DINNER
KEYNOTE ADDRESSES (Van Home Baliroom BC)

Sunday, Decombor 1

Chaipersons: Philip C. Hanawalt, Stanford University, Stanford, CA, and Maloolm C. Paterson, Cross Cancer Institute, Edmonton, Alberta, Canada

Opening Remarks: Majcolm C. Paterson

Pichand B. Sollow, Brookhaven National Laboratory, Upton, NY, "A Personal Historical View of DNA Repair and Where It Might Co."

Bruce N. Ames, University of California, Berkeley, CA, "Understanding the Causes of Aging and Cancer."

0.00 p.m. to 11.00 p.m.

7:00 a.m. to 8:00 a.m.

Monday, Docember 2

BREAKFAST

8:30 a.m. b $11: 30$ a.m. DNA REPAR: BASIC MECHANISUS (Van Home Baliroom BC)

Chaiperson: Lawrence Crossman, Johns Hopkins University, Battimore, MD

Gwendolyn B. Sancar, University of North Carolina, Chapel Hill, NC, DNA Photolyase: A Multifuncwonal Enzyme Encoded by a Damage Inducible Gene."

Bennet Van Houton, University of Vermont, Burlington, VT, "DNA Damage Rocognition and Processing by the Escherichia coli UVRABC Nuclease Complex."

Lawrence Grossman, "The Role of ATP $\Leftrightarrow$ ADP Equilibria in E. Coli Uvr A2B Endonuclease Catalyzed-Reactions."

Errol C. Friecberg, University of Texas Southwestem Medical Center, Dalas, TX, "Nudeotide Excision Repair ir. Eukaryotes: Recent Progress."

Philip C. Hanawalt, Stanford University, Stanford, CA, "Fine Structura of DNA Repair in the Mammalian Cenome."

\begin{abstract}
$11: 45$ a.m. to 1:15 p.m.
4:30 p.m. $06: 30$ p.m.

$6: 30$ p.m. 18.00 p.m.
\end{abstract}

8.00 p.m. v $10: 30$ p.m.

\author{
LUNCH \\ POSTER SESSION A (Presidont's Hell) \\ DINNER \\ BREAKOUT 8ESBONS
}

\section{LEstons (Ven Home Baliroom A)}

Chaiporson: Bea Singer, Ur wersity of Calffomia, Borkeley, CA

Bea Singer, "A Now Human Ropair Protein Rocognizing a Bulky Adduct.

Mutsuo Sekiguchi, Kyushu University, Fukuoka, Japan, "Enzymatic Repair of Oo-Methylouanine and Elimination of 8-Oxopluaninecontrining Nudeotide."

Peter Selow, University of Connecticut, Farmington, CT, "Bacterial Spore Phobchemistry Rovished."

Putus S. Day III, Cross Cancer Instituts, Edmonton, Aberta, Cenada, "Celluter Response to O' Mathylousenine in Mer" Colls."

Picherd J. Roynolds, Los Alamos National Laboratory, Los Alamos, NM, "Induction and Repair or Closety Cpposed, Cyclobutyl Pyrimidine Dimers."

Douglas E. Brash, Yale University School of Mecicine, New Haven, CT, "Exciaion Pepair at the DNA sequence Lovel in the Conome: Why Does Sunlight Induce p5s Mutations in Skin Cancer? 


\section{SYSTEMS (Theatre)}

Cheiperson: John M. Boyle, Christio Hospital and Holt Radium Institute, Manchester, England

Pionald D. Loy, Lovelace Medical Foundation, Abuquarque, NM, "Animal Modols in Photobiology."

Betsy M. Suthertand, Brookheven National Laboratory, Upton, NY, "Strategies for Repair of UV Damage in Human Skin in Situ."

Bary S. Rosenstbin. Mount Sinai School of Modicine, New York. NY, The Induction and Ropair of Solar UV inducod DNA Dameges."

Stuart Lim, University of Calitomia, Berkeley, CA, Perplexing Problems in DNA Repair: How Dose a DNA Damage Binding Protein

Rolato to XP.E? How Does UV Endonuclease IIL. IP Endonuclease I Relate to XP.D, Cyclobutane Dimers, and Ribosomes? Louise Prakash, University of Rochester Modical Linter, Rochester, NY, The Evolutionarily Consenvod RAD6 Protein Mediatos

N-End Dependent Protein Degradation."

\section{WDUCIBLE RESPONSES (Van Home Balroom BC)}

Chaiperson: William L. Carrier, Oak Ridge National Laboratory, Oak Ridge, TN

Bruce Demple, Hanvard University, Cambridge, MA, "Cellular Responses to Oxidative Damage."

Roberta Cottlieb, University of Califomia at San Diego, La Jolla, CA, "AP-1 as a Mociator of the Mammalian UV Response."

Cuy G. Poirier, Laval University Central Hospltal, Sainto-Foy, Quebec, Canada, "Poly(ADP-ribose): A Unique Response in

Eucaryotic Cells to DNA Damage."

Steven G. Sedgwick, National institute for Modical Research, London, England, "Protein Splicing in the Maturation of the recA Gene

Product of Mycobacterium tuberculosis."

Ronald E. Yasbin, University of Maryland, Baltimore, MD, DNA Repair and Regulation among Gram Positive Bacteria: Interactions of Complex Clobal Regulatory Networks."

7.00 a.m. 10 8:30 a.m.

Tuosday, Docombor 3

8:30 a.m. to $11: 30$ a.m.

BREAKFAST

MUTAGENEsis (Van Home Ballroom BC)

Chaiperson: Robert C. von Borstel, University of Aberta, Edmonton, Alberta, Cansda

Graham C. Walker, Massachusetts instiute of Tectnology, Cambridge, MA, Intertwining of Rogulation and Function in Muthonesis."

Barny W. Glickman, University of Victoria, Victoria, British Columbia, Canada, Mutational Specificity and Our View of the Mochanisms of Mutation."

Arthur P. Groliman, State Univorsity of Now York, Stony Brook, NY, "Abasic Sitos and 8-Oxopurines."

Veronica M. Maher, Michigan Stano Univerdity, East Lansing, MI, "Mochanisms of Carcinogen-induced Mutagenesis in Diploid Human Colts: Role of DNA Repair."

Michael M. Soidman, Otsuka Pharmaceutical Company, Rockville, MD, Mochanisms of Uttraviolet Mutagenesis in Human (Xerodorma Pigmentosum) Colls."
11:45 am. to 1:15 p.m.
LUNCH
$4: 00$ p.m. 10 6:30 p.m.
POSTER 8ESSION B (President's Hall)
6:30 p.m. to 8:00 p.m.
DINNER
8.00 p.m. to 10:30 p.m.

\section{BREAKOUT 8EESHONS}

HUMAN POPULATION RESPONSE HETEROGENETY (Van Homo Ballroom A)

Chaiperson: Robert H. Haynes, York University, Toronto, Ontario, Canada

Richerd J. Abertini, University of Vermont, Burtington, VT, The Emerging Picture of Somatic Mutations in Humans."

Daniel W. Nebert, University of Cincinnati Medical Center, Cincinnati, OH, "Dual Role of Drug-metabolizing Enzymes in Cencer?"

Thomas R. Skopek, University of North Carolins, Chapel Hill, NC. Toxicity, Mutagenicity, and Mutational Spectra of

NEthyl-Nnitrosourea in Human Cell Lines with Difforent DNA Repaip Phenotypes."

Micheol A. Bender, Brookheven National Laboratory, Upton, NY, Variation in Cytogenetic Response of Lymphocytes from a Normal Humen Population Sample to Challenge with Verious Mutagens."

\section{ANTAGENOMKC DNA REPAR HETEROGENETY (Van Home Ballroom BC)}

Chvipercon: Vithelm A. Bohr, National Cencer Institute, Bothecda, MD

Viheim A. Bohr, "Cone Specific DNA Popair in Resistent Mammalian Coll Lines."

Micheel J. Smerdon, Washington Stat University, Pullman, WA, Propair Heterogeneity in a Yeast Minichromosome."

Reginald A. Deering, Pennsytvania State Univereity, University Park, PA, "Differential Ropair in Dovelopmentally Regulated Cenes

in Dienostelium discoidoum."

Leon H. F. Mullenders, University of Leiden, Leiden, The Nethertands, "Hierarchies of DNA Repair and Biological Consequences."

Darel J. Hunting, Shertrooke Univercity Contral Hospital, Sherbrooke, Quebec, Canada, Unusual Features of DNA Excision Repair

in XP Group C Colls."

Ceorge J. Kantor, Wrioht Stat University, Dayton, OH, Tdontification of Specific DNA Repair Domains in XP Croup C Colls." 
7.00 a.m. $68: 30 \mathrm{am}$.

$8: 30 \mathrm{em}$. to $11: 30 \mathrm{e.m}$.
Wodnescisy, December 4

BREAKFAST

HUMAN REPAIR GENE CLONING (Alhambra)

Chidiperson: Lerny H. Thompson, Lewrence Livenmore National Laborabory, Livermore, CA

Kyoji Tanaka, Osaka University, Osaka, Japan, "Molecular Analysis of Xeroderma Pigmentosum Group A."

Christine A. Wober, Lewrence Livermore National Laboratory, Livermore, Califomia, "Characterization of ERCC2 and its Correction

of Xoroderma Pigmentosum Group D."

Christine Troelstra, Erasmus University, Rottendam, The Netherlands, "Molecular Analysis of Genes Imvolved in Mammalian ONA Popar."

Cordon F. Whitmore, Ontario Cancer Instituta, Toronto, Ontario, Canada, "UV and X-Ray Sensitive CHO Mutants: Properties and Progress in Cone Cloning."

Pichard A. Gatti, UCLA School of Medicine, Los Angeles, CA, "Ataxia-Telangiectasia: Linkage Evidence for Genetic Heterogeneity." John P. Mumane, University of California, San Francisco, CA, "Cloning and Characterization of a Putative Ataxia-Telangiectasia Cone."
11:45 am. to 1:15 p.m.
LUNCH
3:15 p.m. 10 6:15 p.m.
AGING (Ahambra)

Chaiporsen: Ronald W. Hart, National Conter for Toxicological Research, Jefferson, AR

Ronald W. Hart, "Nutritional Modification of DNA Damage, Repair, Replication, and Expression."

Raymond J. Monnat, Jr., University of Washington, Seatte, WA, "Molecular Analysis of the Wemer Syndrome Mutator Phenotype." John Papaconstantinou, University of Texas Modical Branch, Galveston, TX. The Effect of Aging on the A ute Phase Response:

The Role of Cis- and Trans-acting Factors in Age-related Changes of the Acute Phase Response."

Kunt Randerath, Baylor College of Modicine, Houston, TX, "Endogenous DNA Adducts: Role in Carcinogenesis and Aging?"

Eugenia Wang. Ledy Davis Institute for Modical Posearch, Montreal, Quebec, Canada, "Negative Control of Prulfieration in Senescent Fibroblests."

$6: 30$ p.m. to 7:30 p.m.

$7: 30$ p.m. 1011.00 p.m.
MIXER (Pivoniow)

BANQUET, WILDERNESS NIGHT" PRODUCTION, ROAST, DANCE (Aiberta) Robert H. Haynes, "Roastmastor"

\section{Thureday, Decomber 5}

BREAKFAST

HUMAN GENETIC DISEASE (Ahambra)

8:30 to $11: 30 \mathrm{a.m}$.

Chaiporson: James D. Regan, Oak Pidge National Laboratory, Oak Pidge, TN

demes L German III, The Now York Blood Center, New Yórk, NY, "Clinical-Laboratory Interactions in Imvestigating Collular

Responses to DNA Damage."

James E. Cloever, Uriversity of Calffomia, San Francisco, CA, "How Many Repair-deficient Diseases and How Mamy Cenes?"

Alan R. Lehmann, University of Sussex, Brighton, England, "Rolationships between Xeroderma Pigmentosum, Cockayno's Synctome, and Trichothiodystrophy."

Malcolm C. Paterson, Cross Cancer Instute, Edmonton, Aberta, Canada, "Radiosensitivity in Ataxia-Telangiectasia: A New Explanation Involving Anomalous Signal Transduction."

Lary H. Thompson, Lewrence Lvermore National Laboratory, Lvermore, CA, "Using Rodent Cell Lines and Cenes b Charecterize and Model Human Repair Disorders."
11:45 am. to 1:15 p.m.
6.00 p.m. i $7: 30$ p.m.
LUNCH
DINNER
730 p.m. to 10:30 p.m.
CARCINOOENESIS (Ahambra)

Cheiporson: Curtis C. Harris, Nationst Cancer Instituts, Betheada, MD

I. Bemard Weinstain, Columbia University Colloge of Physicians and Surgeons, New York, NY, "Disondere in Signal Traneduction in Reeponse to Tumor Promoters or DNA Damage."

Curtis C. Harris, "p53 Mutation in Human Cancer."

Poler A. Centti, Swiss Institute for Experimental Cencer Rosearch, Lausanne, Swizerland, "Oxidant Carcinogenesis, Continued." Holene 2. Hill, New Jereoy Medical School, Newark, NJ, The Role of Molanin in the Photo- and Radiobiology of Malignant Molanoma.

Arin Saresin, Instute lor Scientific Research on Cancer, Vilojulf, France, Oncogene Activation in UV-incuced Skin Jumors trom Normd individuats and Xeroderma Pigmencoum Patients and in a Carcinogen-trensformed Xoroderma Pigmentosum Cell Line."

$7.00 \mathrm{am} . \mathrm{to} 0.00 \mathrm{em}$.

Moming times to be ennounced

(firat bus baves at 6:30 am.)
Friday, Decomber 6

BREAKFAST

BUSES LEAVE FOR CALCARY AIRPORT 


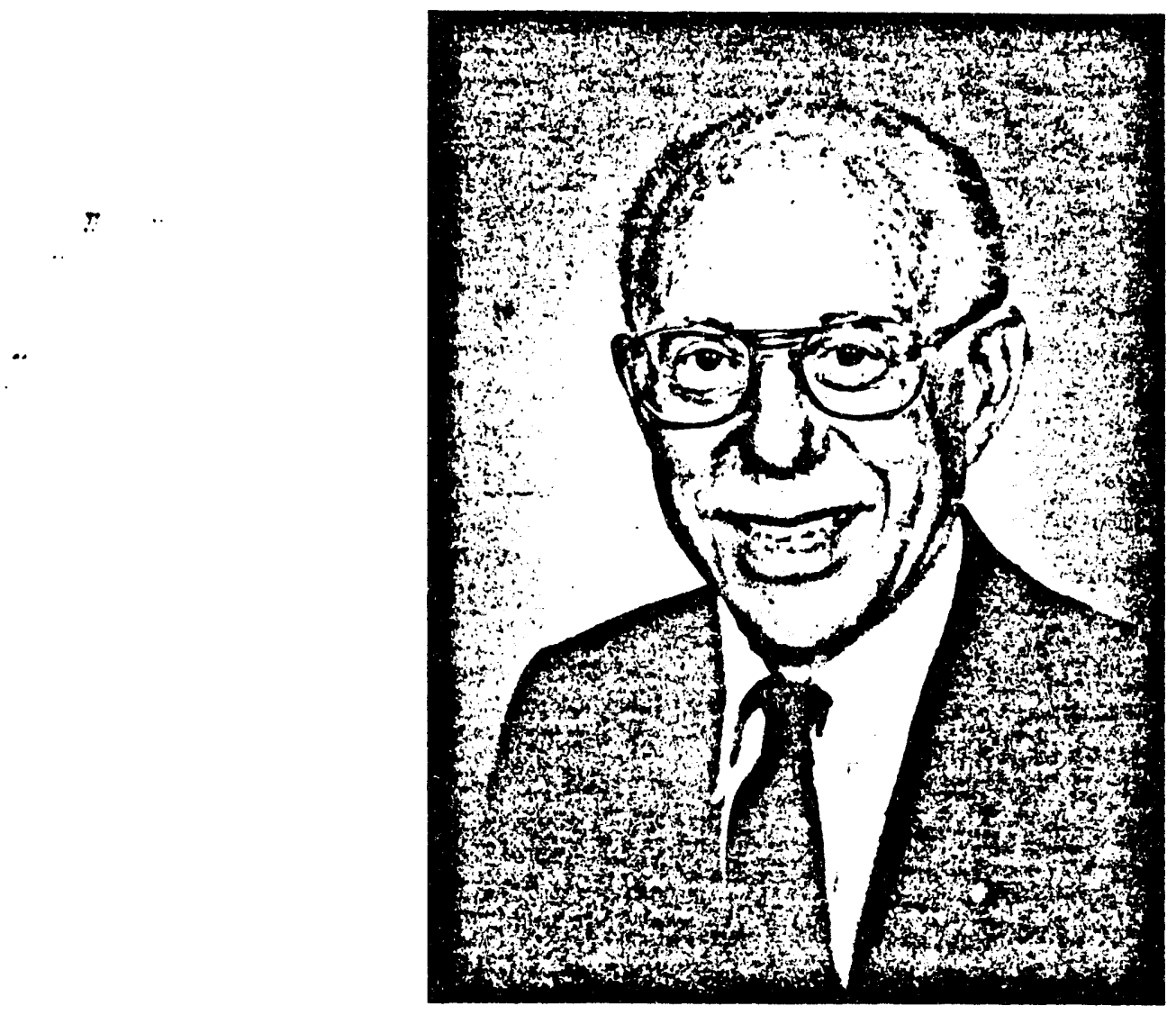

An AACR-sponsored Special Conference in Cancer Research, entitled "Cellular Responses to Environmental DNA Damage," to be held December 1-6, 1991 in Banff, Alberta, Canada, will mark the 70th birthday of Richard B. Setlow, Ph.D. It will provide an opportunity for colleagues and former students to acknowledge his considerable achievements in a long career of leadership in the biology of radiation damage to DNA and repair of this damage.

After receiving an A.B. degree from Swarthmore College in 1941, Dr. Setlow obtained a Ph.D. in physics from Yale in 1947. He continued conducting research and teaching at Yale until 1961, when increasing interest in the biophysics of the effects of radiation on proteins, DNA, and living cells drew him to Oak Ridge National Laboratory Biology Division. Starting as a group leader, he rose to Scientific Director in 1969 and, while holding a professorship of biomedical sciences at the University of Tennessee, he was appointed Director of the University's Graduate School of Biomedical Sciences. In 1974, he joined the Brookhaven National Laboratory as Senior Biophysicist with an adjunct professorship at the Stonybrook campus of the State University of New York. In 1986, he was made Associate Director for Life Sciences.

At Yale, Dr. Setlow undertnok studies on the quantitative direct effects of ionizing and UV radiation on proteins and nucleic acids. Working with colleagues Richard Boyce, Reginald Deering, Philip Hanawalt, and Jane Setlow, he became intrigued by the effects of radiation on viruses, cell division, and macromolecular synthesis. He was induced to move to Oak Ridge where he could spend all of his time on research.

Early in his career, he discovered that thymine dimers in oligo- and polynucleotides and DNA were formed by UV irradiation and, in collaboration with Paul Swenson and William Carrier, that dimers were responsible for profound effects of radiation on DNA synthesis in Escherichia coli. The inhibition was extreme in UV-sensitive mutants and the difference was found to be due to an inability to remove thymine dimers by nucleotide excision repair. Excision repair, a key to radiation resistance, was extended to a variety of biological systems: viruses; microorganisms; and cells in culture.

Among the outstanding accomplishments of his litboratory are the following. He constructed action sp:ctra for UV damage to DNA due to stratospheric ozone depletion by supersonic planes or chlorofluorocarbons. With Ronald Hart, he found that the capacity of cells to repair DNA after UV irradiation was related to the life span of the species tested. To assess the role of thymine dimers in UV-induced tumorigenesis Dr. Setlow, together with Ronald Hart and Avril Woodhead, used as an experimental model a fish species, Poecilia formosa, known as Amazon mollies. This is an isogenic species which has a high level of photoreactivating activity. By irradiating single cell suspensions of thyroid tissue at $254 \mathrm{~nm}$ and subjecting some of these to photoreactivating conditions followed by injection into isogenic recipients, they showed that, while tumors developed by UV radiation alone, 
tumors did not develop after UV radiation followed by photoreactivation.

In experiments now under way at Brookhaven, he is measuring variations in biochemical and cytogenic end points to assess how DNA repair differs among normal human populations and whether repair activity is constant over time. He is also studying another fish model, a hybrid cross of platyfish and swordtails of known genetic composition that is highly susceptible to UV-induced melanoma, to assess the role of melanoma susceptibility genes and tumor suppressor genes in melanoma formation.

Dr. Setlow is a member of the National Academy of Sciences, the American Academy of Arts and Sciences, and numerous professional societies, including the AACR. He was president of the Biophysical Society, 1969-1970; the Fifth International Congress on Photobiology, 1968; and the Comité International de Photobiologie, 1972-1976, and is Honorary President of the 11th International Congress on Photobiology, Kyoto, Japan, to be held September 7-12, 1992. He served, and continues to serve, on a host of National
Research Council Committees; as an advisor to many agencies dealing with photobiology and cancer; and on many editorial boards, including that of Cancer Research. He has received honors from the Radiation Research Society and has been awarded the Finsen Medal at the 8th International Congress on Photobiology, Strasbourg, France, 1980, and the Enrico Fermi Award of the United States Department of Energy, 1988. He has an honorary Doctor of Science degree from York University, Canada, 1985, and is a Fellow of the American Association for the

Advancement of Science, 1988. He is the author or coauthor of 246 papers; readers are referred to the following reviews: Nature (Lond.), 271: 713-717, 1978; Natl. Cancer Inst. Monogr., 60: 249-255, 1982; Human Carcinogenesis, C. C. Harris and H. N. Autrup (eds.), pp. 231-254, 1983; and DNA Damage and Repair, A. Castellani (ed.), pp. 1-9, 1989.

We are indebted to Dr. Setlow for the photograph and information. 


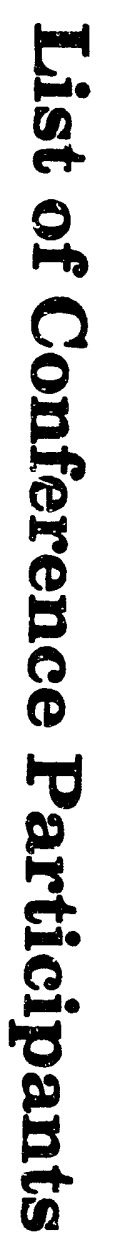


CELLULAR RESPONSES TO ENVIRONMENTAL DNA DAMAGE IIST OF PARTICIPANTS

Dr. Anthony M. Abel

University of Iiverpool

School of Life sciences

Dept. of Genetics s Microbiol.

Donnan Labs.

Iiverpool, Merseyside

$$
\text { L69 } 38 \mathrm{BX} \text { INGLAND }
$$

Dr. Gerald H. Adair

UT M. D. Anderson Cancer Ctr.

Science Park-Research Division

P.0. Box 389

Smithvilie, Texas

78957 USA

Dr. Byungchan Ahn

The Johns Hopkins University

Dept. of Blochemistry

615 N. Wolfe Street

Baltinore, Maryland

21205 USA

Dr. Richard J. Albertini

Univ. of Vermont Coll. of Med.

VRCC Genetics Lab.

32 N. Prospect st.

Burlington, Vermont

O5401 USA

DI. Erancis Ali-Osman

UT M. D. Anderson Cancer Ctr.

Dept. of Exper. Pediatrics

Box 88

1515 Holcombe Blva.

Houston, Texas

77030 USA

Dr. Alan Anderson

Laval University

Cancer Research Center

1'Hotel-Dieu de Quebec

11. cote du Palais

Quebec, Quebec GIR $2 J 6$

CANADA

Dr. Jalme Angulo

CARS, GEMC

Lab. of Enzymology

1 av. de la Terrasse

91198

Gif-sur-Yvette, ERANCE
Dr. Jic J. Ackerman

NIDDK - NIH

Bldg. 10, Room 9D15

Bethesda, Maryland

20892 USA

Dr. Ahmed E. Ahmed

Univ. of Texas Medical Branch

Dept. of Pathology, F05

Galveston, Texas

77550 USA

Dr. Steven A. Akman

City of Hope Hational Med. Ctr.

Department of Medical Oncology

1500 E. Duarte Road

Duarte, California

91010 USA

Dr. Rowyda N. Al-Harithy

King Faisal Hosp. Res. Ctr. Blological and Medical Research P.O. Box 3354

11211

Riyadh,

\section{SAUDI ARABIA}

Dr. Bruce N. Ames

Univ. of California

Div. of Blochem. and Mol. Blo. 401 Barker Hall

Berkeley, California

94720 USA

Dr. Barbara M. Andon

Nickel Produceri Env. Res. Assoc.

Alston Technical Park

100 Capitola Drive, Suite 194

Durham, North Carolina

27713 USA

Dr. Hiroshi Asahina

Osaka University

Inst. for Mol. C Cell Blology

Div. of Cellular Genetics:

1-3 Yamada-oka, sulta

Osaka, 565 JAPAN 
Dr. Katherine A. Atkins

Vanderbilt University

Center in Molecular Toxicology

Dept. of Blochemistry

21st Avenue Garland

Mashville, Tennessee

37232-0146 USA

Dr. Felix J. Baker

Stanford Universtty

Dept. of Blological sciences

Stanford, California

94305-5020 USA

Mr. Saber Bashir

The London Hospital Hed. College

Bone and Joint Research Unit

Ashifield Street

London.

EI 2AD ENGLAND

Dr. Kenneth W. Bayles

Univ. of Maryland Baltimore Co.

Dept. of Blological sei.

5401 Wilkens Avenue

Baltimore, Maryland

21228 USA

Dr. Blake C. Beehler

Roswell Rark Cancer Center

Dept. of Exp. Therapeutics

EI and Cariton streets

Buffalo, New York

14263 USA

Dr. Elisabeth C. Bertrand

CNRS-Inst. of Molecular Biology

15. rue Descartes

67000

strasbourg,

FRANCE

Dr. Ranjana P. Bird

Univ. of Manitoba

Dept. of Foods \& Nutrition

H515 Duff Roblin Bldg.

Hinnipeg, Manitoba R3T $2 \times 2$

CANADA
Dr. W1lliag M. Batrd

Purdue University

Dept. of Medicinal Chemistry

Pharnacy BIdg.

W. Lafayette, Indiana

47967 USA

Dr. Sadayuki Ban

Radiation Effects Research Fndn.

Dept. of Geneties

5-2 Hijiyama Park, Minami-ku

732

Hiroshima,

\section{JAPAN}

Mr. Thomas M. Basile

Chadbourne and Parke

30 Rockefeller plaza, 23rd Floor

Hew York, Hew York

10112 USA

Mr. Jirair $K$. Bedoyan

Michigan State University

Dept. of Blochemistry

Carcinogenesis Lab.

Fee Hall

East Lansing, Mlchigan

48824-1316 USA

Dr. Michael A. Bender

Brookhaven Hational Lab.

Med. Dept.

Assoctated Univ.

Bldg. 490

Upton, New York

11786 USA

Dr. Hilliam L. B1gbee

Lawrence Livernore National Lab.

Blological Dosimetry Group

Blomed. Sc1. DIV. L-452

P.O. Box 5507

Livermore, California

94550 USA

Dr. Vilhelm A. Bohr

NCI, Bethesda, Maryland

Lab. of Mol. Pharm.

Bullding 37, Room 5C-25

Bethesda, Maryland

20892 USA 
Dr. Whynn Bosnich

Cross Cancer Institute

Molecular Genetics and

Carcinogenesis Lab.

11560 University Avenue

Edmonton, Alberta

TEG 122 CANADA

Dr. John M. Boyle

Christie Hosp. Holt Radium Inst.

Paterson Inst. for Cancer Res.

Winslow Road

Manchester.

M20 98X ENGLAKD

Dr. Thomas $P$. Brent

St. Jude Children's Res. Hosp.

Dept. of Pharnacology

332 N. Lauderdale

Memphis, Tennessee :

38101 USA

Dr. Garry W. Buchko

Cross Cancer Institute

Dept. of Radiobiology

11560 University Avenue

Edmonton, Alberta

T6G 122

CANADA

is

Dr. Ross N. Butler

The Queen Elizabeth Hospital

Dept. of Gastroenterology

28 Woodvilie Road

Woodville South, South Australia 5011

AUSTRALIA

Dr. Salvatore J. Caradonna UMDNJ-\$OM

Dept. of Molecular Blology

401 S. Central Plaza

stratford, New Jersey

08084 USA

Ms. Madeleine Carreau

University of Sherbrooke

Dept. of Nuclear Medicine

Faculty of Medicine

300112 th Avenue Horth

Sherbrooke, Quebec

I1H $5 N 4$ CANADA
Dr. Jayne C. Boyer

N.I.E.H.S.

Lab. of Molecular Genetics

P. 0 . Box 12233

B3-01

Res. Triangle Park, North Carolina 27709 USA

Dr. Douglas E. Brash

Yale Untv. School of Med.

Dept. of Therapeutic Rad.

333 Cedar st./HRT 315

New Haven. Connecticut

06510 USA

Dr. Richard J. Bucala

Rockefeller University

1230 York Avenue

BOX 277

New York, New York

10021 USA

Dr. David I. Busbee

Texas A \& University

Dept. of Anatomy and Fub. Health

College of Veterinary Medicine

Div. of Cell Biology

College station, Texas

77843 USA

Dr. Keith Caldecott

Lawrence Livermore National Lab. Biomedical Sciences Div.

P.0. Box 5507

ivermore, Callfornia

94550 USA

Dr. Neal F. Cariello

Univ. of North Carolina

Dept. of Pathology

Campus Box 7095

Chapel Hill, North Carolina

27599 USA

Dr. William L. Carrier

Oak Ridge National Lab.

Biol. Div.

P. O. Box 2009

Oak Ridge, Tennessee

37831-8077 USA 
Dr. Tinothy S. Carter

St. John's University

Dept. of Blological sciences

Grand Central and Vtopia Pkwys.

Jama1ca, Hew York

12439 USA

Dr, Peter A. Cerutt1

Swiss Inst. for Exp. Cancer Res. CH-155-1066

Epalinges/Lausanne,

SWITZERLAND

Dr. David Chen

Los Alamoz National Laboratory

Life sciences Division.

MS -4888

Ior Alamos, New Mexico

87545 USA

Dr. Theodore K. Cho1

Gengharm International. Inc.

2375 Garcia Avenue

Mountain View, California

94043 USA

Dr. James E. Cleaver

Univ. of California

Lab of Radiobiol. E Env. Health LR-102, BOX 0750

San Erancisco, California

94143 USA

Dr. Priscilla K. Cooper

Lawrence Berkeley Laboratory

University of California

Bullding 934

Berkeley, California

94720 USA

Dr. Meenaksh1 D. Dabholkar

Mational Cancer Institute

Hedlcine Branch

Bldg. 10, Room 6N107

Bethesda, Maryland

20892 USA
Dr. Michael R. Carty

University of Cincinnati

Dept. of Environmental Health

Kettering Lab.

3223 Eden Avenue

Cincinnati, Ohio

45267-0056 USA

Dr. Ming J. W. Chang

Chang Gung Medical College

Dept. of Public Health

259 Hen-Hua 1st Road

Tao-Yuan, Taiwan

R. O. C.

Mr. David Cheo

Univ, of Maryland Baltimore Co.

Dept. of Blological sci.

5401 Wilkens Avenue

Baltimore, Maryland

21228 USA

Mr. Fred C. Christians

Stanford Universicy

Dept. of Biological sciences

Stanford, California

94305-5020 USA

Dr. Joelle Collignon

University of Liege

Dept. of Hematology

CHU

$B-4000$

Sart Tilman, Lisge

BELGIUM

Ms. Anita H. Corbett

Vanderbilt University

Dept. of Biochemistry

621 Hight Hall

Nashvilie, Tennessee

37232-0146 USA

Dr. Rufus S. Day

Cross Cancer Institute

11560 University Avenue

Edmonton, Alberta

T6G 122 CANADA 
Dr. Reginald A. Deering

Benn State Univ.

Molecular and Cell Blol.

University Park, Pennsylvania

16802 USA

DI. Serge Desnoyers

Laval Univ. Medical Center

Dept. of Molecular Endocrinology

2705 Laurier Boulevard

ste. Foy, Quebec

GIV 4G2 CANADA

Dr. Grigory Dianov

Imperial Cancer Research Fund Clare Hall Labs.

Blanche Lane, South Mimms

Herts,

EN6 3LD ENGLAND
Dr. Bruce Demple

Harvard School of Public Healeh Lab of Tox.

665 Huntington Avenue

Boston, Massachusets

02115 USA

Ms. Pallavi R. Devchand

Univ. of Calgary

Dept. of Medical Biochenistry

3330 Hospital Dr.. N.W.

Calgary, Alberta

T2N 4N1 CANADA

Dr. Ruth L. Dusenbery

Wayne State University

Dept. of Chemistry

Detroit, Michigan

48202 USA

Dr. Louise M. Enns

Dr. Suzanne Egyhazi

Karolinska Hospital

Dept. of Exp. Oncology

Radiumbemet

S- 10401

Stockholm,

SWBDEN

Dr. Leonard C. Erickson Loyola University Chicago

Section of Hema./Onc., 54/049

2160 South First Avenue

Maywood, Illinois

60153 USA

Dr. Hans-Pietro Eugster

University of Zurich

Swiss Fed. Inst. of Technology

Institute of Toxicology

Schorenstr. 16

schwerzenbach,

$\mathrm{CH}-8603$

SWITZERLAND

Dr. Oskar S. Frankfurt

Cedars Medical Center

Oncology Laboratory

1400 N.W. 12 th Avenue

Miami, Florida

33136 USA
Cross Cancer Institute

Molecular Genetics and

Carcinogenesis Lab.

11560 University Avenue

Edmonton, Alberta

T6G 122 CANADA

Dr. Allen Eskenaz1

Univ. of Maryland Sch. of Med.

Pediatric Hematology/Oncology

22 South Greene Street, Box 123

Baltimore, Maryland

21201 USA

Dr. Michele K. Evans

National Cancer Institute

Lab. of Molecular Pharmacology

Bldg. 37 , Room 5C25

9000 Rockville Pike

Bethesda, Maryland

20892 USA

Dr. Marvin Frazier

U. S. D. O. E. (GTN)

Health Effects and Life sciences

Research Division, ER-72

Washington, District of Columbia 20585 USA 
Dr. Errol C. Friedberg

UT Southwestern Med. Ctr.

Dept. of Path.

5323 Harry Hines Blvd.

Dallas, Texas

75235-9072 USA

Dr. Anrie M. Galloway

Cross Cancer Institute

Molecular Genetics and

Carcinogenesis Lab.

11560 University Avenue

Eduonton, Alberta

T6G 122 CANADA

Dr. Janes W. Gaubstz

Univ. of South Alabama

Dept. of Blochemistry

MSB 2198

Mobile, Alabama

36688 USA

Dr. Stanton I. Gerson

University Hospitals of Cleveland

Ireland Cancer Center

Dept. of Medicine

2074 Abington Road

Cleveland, Oh10

44106 USA

Dr. David J. Gingrich

The Johns Hopkins University

Hygiene/Biochemistry

$615 \mathrm{H}$. Nolfe Street

Baltinore, Maryland

21205 USA

Dr. Roberta Gottlieb

Univ, of California, San Diego

Dept. of Pharmacology, 0636

School of Medicine

9500 G11man Drive

La Jolla, Callfornia

92093 USA

Dr. Lawrence Grossman

The Johns Hopkins Univ.

Dept. of Blochen.

615 N. Wolfe'st.

Baltimure, Maryland

21205 USA
Dr. Patricia E. Gallagher

West Virginia University

Dept. of Blology

Brooks Hall

Morgantown, West Virginia

26506 USA

Dr. Richard A. Gatti

UCLA School of Medicine

Dept. of Path.

Los Angeles, California

90024 USA

Dr. James L. German III

The New York Blood Center

310 E. 67 th Street

New York, New York

10021 USA

Dr. Neil W. Gibson

Oniv. of Southern California

School of Pharmacy

1985 Zonal Ave.

Los Angeles, California

90033 USA

Dr. Barry W. Glicknan

University of Victoria

Dept. of Biololgy

Center for Env. Health

R.R. 2, 9865 W. Saanich Road

Sidney, British Columbia V8L 351

CANADA

Dr. Arthur P. Grollman

State Univ. of New York

BHS T-8, 140

Dept. of Pharm.

Stony Brook, New York

11794-8651 USA

Ms. Leonora J. Groves

West Virginia University

Dept. of Biology

Brooks Hall

Morgantown, West Virginia

26506 USA 
Dr. Yvette Habraken

University of Liege

4 rue des Bruveres

B- 4000

Iiege,

BELGIUM

Dr. Richard $T$. Hamner

Strategene

11099 N. Torrey Pines Road

La Jolla, California

92037 USA

Dr. Johan Hansson

Karolinska Hospital

Dept. of General Oncology

Radiumhemmet

S-10401

stockholn.

SWEDEN

Dr. Linda C. Harris

St. Jude Children's Research Hosp. Dept. of Blochem. Clin. Pharm.

P. 0. Box 318

332 N. Lauderdale

Memphis, Tennessee

38101-0318 USA

نे
Dr. Joshua W. Hanilton

Dartmouth Medical School

Pharmacilegy \& Toxicology Dept. Lyme Roac

Hanover, New Hampshire 03756 USA

Dr. Philip C. Hanawalt

Stanford University

Dept. of Biol. Sci.

Herrin Biol. Lab.

stanford, California

94305-5020 USA

Dr. Curtis C. Harris

National Cancer Institute

Lab. Of Human Carcinogenesis

Bldg. 37, RoOm 2CO1

Bethesda, Maryland

20892 USA

Dr. Ronald W. Hart

Ntl. Ctr. for Tox. Res.

FDA

N. C. T. R. Drive

Jefferson, Arkansas

72079 USA

Dr. Janet Hauser

NICHD, NIH

Bldg. 6, ROOW $1 A 17$

9000 Rockville Pike

Bethesda, Maryland

20892 USA

Dr. Mohammad A. Hedayati

Dr. Robert H. Haynes

York University

Dept. of Biology

North York, Ontario

M3J IP3 CANADA

Dr. Dennis Hellgren

Karolinska Institute

Dept. of Clinical Genetics

S-10401

stockholm.

SWEDEN
Dr. Nancy L. Henderson

DuPont-Merck Pharmaceuticals E328/140C

P.0. Box 80328

Vilmington, Delaware

19880-0328 USA DuPont Experimental station 
Dr. Eric L. Hildebrand

Johns Hopkins University

School of Public Health

Dept. of Biochemistry

615 N. Wolfe Street

Baltimore, Maryland

21229 USA

Dr. Klaus Hochleitner

Univ. of Essen Medical School

Institute of Cell Blology

Hufelandstr. 55

$D-4300$

Essen, 1

GERMANY

Dr. Jennifer J. Hu

Cancer Prevention Research Inst.

36 East 22nd street

New York, New York

10010 USA

Dr. Intisar Husain

Glaxo, Ine.

Five Moore Drive

Res. Triangle Park, North Carolin 27709 USA

Dr. Elaine I. Jacobson

Univ. of North Texas

Texas College of Osteopathic Med.

Dept. of Medicine

3500 Camp Bowie Blvd.

Fort Worth, Texas

$7610^{-} 2690^{\circ}$ USA

Dr. Timothy M. Jenkins

NIDDK-NIH

BIdg. 10, Room 9D15

Bethesda, Maryland

20892 USA

Dr. Timothy J. Jorgensen

Georgetown University

Dept. of Radiation Medicine

3800 Reservoir Road, N.W.

Washington, District of Columbia

20007-2197 USA
Dr. Helene 2 . Hill

New Jersey Med. School

section of Cancer Biol.

Roon MSB-E586

Newark, New Jersey

07103-2714 USA

Dr. Jean-Sebastien Hoffmann

University of Washington

J. Gottstein Mem. Cancer Res. Lab.

Dept. of Pathology, SM-30

Seattle, Washington

98195 USA

Dr. Darel J. Hunting

Sherbrooke Univ. Cent. Hosp.

Dept. of Nuclear Medicine \&

Radiobiology

stoke Road

Sherbrooke, Quebec

J1H 5N4 CANADA

Dr. Christine M. Ireland

Prince of Wales Children's Hospital

Children's Leukemia \& Cancer Res.

Villa 1

High street, Randwick

Sydney, Hew South Wales 2031 AUSTRALIA

Dr. Slegfried Janz

National Cancer Institute

Laboratory of Genetics

Bldg. 37, RoOn 2BO9

Bethesda, Maryland

20892 USA

Mr. Robert E. Johnson

Univ. of Rochester

Dept. of Blophysics

601 Elmwood Ave.

Rochester, New York

14642 USA

Dr. Doug Kalinowsk1

University of Vermont

Dept. of Pathology

Medical Alumni Bldg.

Burlington, Vermont

05405 USA 
Dr. George J. Kantor

Wright state Univ.

Dept. of B10. Sc1.

Dayton, Ohio

45435 USA

Dr. Johanna C. Klein

The Netherlands Cancer Institute

Dept. of Chemical Carcinogenesis

Plesmanlaan 121

$1066 \mathrm{CX}$

Amsterdam,

THE NETHERLANDS

Dr. Yoshinori Kohwi

La Jolla Cancer Research Fndn. 10901 N. Torrey Pines Road

La Jolla, California

92037 USA

Dr. Wolfgang Kusser

University of Victoria

Dept. of Blology

Centre for Env. Health

R.R. 2, 9865 W. Saanich Road

Sidney, British Columbia V8L 351 CAMADA

Dr. Muriel W. Lambert

UMDNJ - New Jersey Medical school

Dept. of Pathology

185 South Orange Avenue

Newark, New Jersey

07103 USA

Dr. Christopher S. Lange

SUNY Health Science Center

Dept. of Radiation oncology

450 Clarkson Avenue, Box 1212

Brooklyn, New York

11203 USA

Dr. Jean J. Latimer

University of California

Lab. of Radiobiology and

Environmental Health

3 rd and Parnassus Avenues

San Francisco, California

94143-0750 USA
Dr. William K. Kaufmann

Univ. of North Carolina

Dept. of Pathology and

Ineberger Comp. Cancer Ctr.

Chapel Hill, North Carolina

27599-7295 USA

Dr. Ulrike Klotz

West Virginia University

Dept. of Blology

Brooks Yall

Morgantown, West Virginia

26505 USA

Dr. Yoke Kow

University of Vermont

Dept. of Microbiology \&

Molecular Genetics

Burlington, Vermont

Q5405 USA

Dr. Jean Lagueux

CHUL Research Center

Molecular Endocrinology Lab.

2705 Laurier Boulevard

ste. Foy, Quebec

$$
\text { GIV } 4 \text { G } 2 \text { CANADA }
$$

Dr. W. Clark Lambert

UMDNJ - New Jersey Medical School

Dept. of Pathology

185 South Orange Avenue

Newark, New Jersey

07102 USA

Dr. Florence Larminat

National Cancer Institute

Lab. of Molecular Pharmacology

Bldg. 37, Room 5C25

9000 Rockville Pike

Bethesda, Maryland

20892 USA

Dr. Christian Laurent

University of Liege

Onc.. Radiobio.. \& Exp. Mut. Lab.

Inst. O Pathology B23

B-4000

sart TIIman, Liege BELGIUM 
Dr. Francoise Laval

Institut Gustave Roussy

39. rue Canille-Desmoulins

94805

villejuif.

ERANCE

Dr. Martin F. Lavin

Queensland Inst. of Medical Res. Bancroft Centre

P.O. Box Royal Brisbane Hosp.

Brisbane, Queensland

4029 AUSTRALIA

Dr. Alan R. Lehmann

University of Sussex

MRC Cell Mutation Unit

Falmer

Brighton,

BN1 9RR BNGLAND

Dr. In Kyoung Iim

UCLA School of Medicine

Dept. of Biological Chemistry

Warren Hall

900 Veteran Ave.

Los Angeles, California

96024-1786 USA

Dr. Stuart M. IInn

Univ. of California

BMB Div.

Barker Hall

Berkeley, California

94720 USA

Dr. Siv Ijungquist

Rarolinska Institute

Inst. of Environmental Medicine

Box 60208

s-10401

stockholm,

SWEDEN

Dr. Erancis J. Lynch

UMDXJ-SOM

Dept. of Molecular Blology

401 s. Central Plaza

Stratford. New Jersey

08084 USA
DI. Jacques Laval

Inst. Gustave Roussy

39. rue Canille-Desmoulins 94805

Villejuif,

\section{FRAYCE}

Dr. Randy J. LegerskI

UT M. D. Anderson Cancer Ctr.

Dept. of Molecular Genetics

1515 Holcombe Blvd.

Houston, Texas

77030 USA

Dr. Ronald D. Ley

Lovelace Med. Fndn.

Div. of Biomed. Res.

2425 Ridgecrest Drive, S.E.

Albuquerque, New Mexico

87108 USA

Ms. Susan E. Lim

The Johns Hopkins University

Dept. of Envrion. Health Sci.

615 N. Wolfe st.

Baltimore, Maryland

21205-2179 USA

Dr. Michel Liuzzi

Bio-Mega, Inc.

Biochensitry Department

2100, rue Cunard

Laval, Quebec

H7S 265

CANADA

Dr. R. Stephen Lloyd

Vanderbilt University

Center in Molecular Toxicology

Dept. of Blochemistry

$21 s t$ Avenue \& Garland

Nashville, Tennessee

37232-0146 USA

Dr. John C. Macaulay

Red Deer Reglonal Hospital

50A Avenue

Red Deer, Alberta

T4R 4E6 CANADA 
Dr. Chia-Miao Mah

Michigan State University

Carcinogenesis Laboratory

B620 W. Fee Hall

E. Lansing, Michigan

48824 USA

Dr. Margaret D. Mamet-Bratley

University of Montreal

Dept. of Biochemistry

C.P. 6128, Succursale A

Montreal, Quebec

H3C $3 \mathrm{~J} 7$ CANADA

Dr. Yoshihiro Matsunoto

state Univ. of New York

Dept. of harmacological sci.

stony Brook, New York

11794 USA

Dr. J. Justin McCornick

Michigan State University

Carcinogenesis Laboratory

B620 W. Fee Hall

East Lansing, Michigan

48824 USA

$\$$

Dr. Karen McLaughlin

University of Glasgow

CRC Dept. of Medical Oncology

Garscube Estate, Switchback Road

Bearsden

Glasgow,

G61 1BD SCOTLAND

Dr. William B. Melchior, Jr.

Nat. Ctr. for Toxicological Res. HET-110

Jefferson, Arkansas

72079 USA

Dr. Razmik Mirzayans

Cross Cancer Institute

Molecular Genetics and

Carcinogenesis Lab.

11560 University Avenue

Edmonton; Alberta

T6G 122

CANADA
Dr. Veronica M. Maher

Michigan State Univ.

West Fee Hall

Carcinogenesis Lab.

East Lansing, Michigan

48824 USA

Dr. Donald S. Masters

Oxigene, Inc.

20 Park Plaza, Suite 447

Boston, Massachusetts

02116 USA

Dr. Judy K. Mayo

The Upjohn Company

Dept. of Investigative Toxicology

301 Henrietta street

Kalamazoo, Michigan

49001 USA

Dr. W. Glenn McGregor

Michigan State University

Carcinogenesis Laboratory

B620 W. Fee Hall

East Lansing, Michigan

48824 USA

Dr. Mary P. McLenigan

NICHD, NIH

Bldg. 6, ROOW 1 A15

9000 Rockville Pike

Bethesda, Maryland

20892 USA

Dr. Raymond E. Meyn

UT M. D. Anderson Cancer Ctr.

Dept. of Exp. Radiotherapy

Box 66

1515 Holcombe Blvd.

Houston, Texas

7700 USA

Dr. Hiroshi Mitani

University of Tokyo

zoological Institute

raculty of science

Hongo 7-3-1, Bunkyo-ku

Tokyo,

$$
113 \text { JAPAN }
$$


Dr. Raynond J. Monnat, Jr.

Univ. of Washington

Dept. of Path.

SM-30

seattle, Washington

98195 USA

Dr. Masaak1 Moriya

state UnIv. of New York

Dept. of Pharmacological sci.

Stony Brook, New York

11794-8651 USA

Dx. Janes P. Mueller

Washington State UnIv.

Dept. of Blochen./Blophys.

Synthesis 670

Pullman. Washington

99164-4660 USA

Dr. Leon H. F. Mullenders

state Univ. of Leiden

Dept. of Rad. Genetics \& Chem.

P. O. Box 9503

Leiden,

$$
2300 \text { RA NETHERLANDS }
$$

Dr. John P. Murnane

Univ. of California

Lab. of Radiobiol. E Env. Health

San Erancisco, California

94143-0750 USA

Dr. Frank Q. H. Ngo

Cleveland Clinic Foundation

Dept. of Radiobiology

One clinic Center

9500 Euclid Avenue

Cleveland, Ohio

44195-5157 USA

Dr. John Papaconstantinou

Univ. of Texas Medical Branch

Dept. of Human Biol. Chem. and Genetics

Basic Sciences Bldg., Room 613

Galveston, Texas

77550 USA
Dr. Carol Wood Moore

City Uni's. of New York Med. School

Dept. o:t Microbiology

Science Bullding, Room 910

i38th St. Convent Ave.

New York, New York

10031 USA

Dr. Dale W. Mosbaugh

Oregon state University

Dept. of Agricultural Chemistry

Corvall1s, Oregon

97331 USA

Dr. Ken L. Mueller

The Johns Hopkins University

School of Hygiene \& Pub. Health

501 N. Wolfe street

Baltimore, Maryland

21205 USA

Dr. Susan J. Muller

UMDNJ-SOM

Dept. of Molecular Blology

401 S. Central Plaza

Stratford, New Jersey

08084 USA

Dr. Daniel $W$. Nebert

Univ. of Cincinnati Med. Ctr.

Lab. of Mol. Toxicology

Kettering Laboratory

3223 Eden Ave.

Cincinnati, Ohio

45267-0056 USA

Dr. Peggy I. Olive

British Columbia Cancer Res. Ctr.

Medical Blophysics Unit

601 W. 10th Ave.

Vancouver, British Columbia

V5Z IL3 CANADA

Ms. Christina Papaparaskeva

University of Surrey

School of Blological sciences.:

Division of Toxicology

Guilford, Surrey

GU2 5XH ENGLAND 
Dr. Craig L. J. Parfett

Health and Welfare Canada

Health Protection Branch

Environmental Health Centre

Tunney's Pasture

ottawa, Ontario

K1A OL2 CANADA

Dr. Ricardo J. Parker

National Cancer Institute

Bldg. 10, Room 6N109

9000 Rockville Pike

Bethesda, Maryland

20892 USA

Dr. Thomas A. Patterson

Du Pont Merck Pharmaceutical Co.

Biotechnology

B.0. Box 80400

Wilmington, Delaware

19880-0400 USA

Dr. Ronald Pero

New York Univ. Medical Ctr.

Dept. of Env. Medicine

PHL -875

550 First Avenue

New York, New York

sis

10016 USA

Dr. Gerd P. Pfeifer

Beckman Research Institute

City of Hope

Dept. of Biology

Duarte, California

91010 USA

Dr. Phillp M. Potter

st. Jude Children's Research Hosp

Dept. of Blochen. \& Clin. Pharm.

P. O. Box 318

$332 \mathrm{~N}$. Lauderdale

Memphis, Tennessee

38101-0318 USA

Dr. Bradley D. Preston

Rutgers University

College of Pharmacy

Lab. for Cancer Research

P.O. Box 789

Piscataway, New Jersey

08855-0789 USA
Mr. Kenneth R. Parker

University of Alberta

Dept. Of Genetics

Edmonton, Alberta

T6G 2E9

CANADA

Dr. Malcolm C. Paterson

Cross Cancer Institute

Mol. Genetics \& Carc. Lab.

11560 Untversity Avenue

Edmonton, Alberta

T6G 122 CANADA

Dr. Antonla Pedrint

Ist. di Genetica Biochimica ed Evoluzionistica C.N.R.

Via Abbiategrasso 207

27100

Pavia,

\section{ITALY}

Dr. Lone Norgard Petersen

University of Copenhagen

Inst. of Pathological Anatomy

Frederik $V^{\prime}$ 's Vej 11

DK 2100

Copenhagen.

DENMARK

Dr. Guy G. Poirier

Imperial Cancer Res. Fund

Clare Hall Lab.

South Mimms, Potters Bar

Herts,

EN6 3LD ENGLAND

Dr. Louise Prakash

Univ. Of Rochester Sch. of Med.

Dept. of Blophys.

601 Elmwood Avenue

Rochester, New York

14642-8408 USA

Dr. Gerald B. Price

MCGill University

McGill Cancer Centre

3655 Drummond street

Montreal, Quebec

H3G 1 Y 6 CANADA 
Mr. Joseph Przybyszewsk1

Roswell Park Cancer Institute

Dept. of Biophysics

EIm and Carlton streets

Buffalo, New York

14263 USA

Dr. Dindial Ranotar

Harvard School of Public Health Molecular Cellular Toxicology 665 Huntington Ave.. Bldg. 1 Boston, Massachusetts 02115 USA

Dr. Erika Randerath

Baylor College of Medicine

Dept. of Pharmacology

1 Baylor Plaza

Houston, Texas

77030 USA

Dr. Aghdass Rasoul1-Nia

Cross Cancer Institute

Molecular Genetics and

Carcinogenesis Lab.

11560 University Avenue

Bdmonton, Alberta

T6G 122

CANADA

Dr. Janes D. Regan

Biol. Div.

Oak Ridge National Lab.

P. O. Box 2009

Oak Ridge, Tennessee

37831-8077 USA

Dr. Craig Robson

Imperial Cancer Research Fund Inst. Of Molecular Medicine

John Radeliffe Hospltal

Headington

oxford.

O\&3 9DU ENGLAND

Dr. Ze'ev A. Ronal

American Health Foundation

Molecular Cárcinogenesis Program One Dana Rd:

Valhalla, New York

10595 USA
Dr. Andre1 Purmal

University of Vermont

Dept. of Mleroblology \&

Molecular Genetics

Burlington, Vermont

05405 USA

Dr. Nicholas J. Rampino

NICHD, MIH

Bldg. 10, Room 6C101

Bethesda, Maryland

20892 USA

Dr. Kurt Randerath

Baylor College of Med.

Dept. of Pharm.

1 Baylor Plaza

Houston, Texas

77030 USA

Dr. Flora Ratpan

MoVA Corporation of Alberta

Health, Safety \& Environment

801 Seventh Avenue, S.W.

Calgary, Alberta

T2P $2 N 6$ CANADA

Dr. Richard J. Reynolds

Los Alamos National Lah.

Life SC1. Div.

Genetics Group

P. O. Box 1663

Los Alamos, Hew Mexico

87545 USA

Dr. Lewis V. Rodriguez

UT M. D. Anderson Cancer Ctr.

Dept. of Molecular Pathology

Box 89

1515 Holcombe Boulevard

Houston, Texas

77030 USA

Dr. Susan M. Rosenberg

Cross Cancer Institute

11560 University Avenue

Edmonton, Alberta

T6G 122 CANADA 
Dr. Barry S. Rosenstein Mount Sinai School of Med. Dept. of Rad. Onc.

Box 1236

One Gustave Levy $P I$.

New York, New York

10029 USA

Dr. Colette J. Rudd

SRI International

Cell Genetics

333 Ravenswood Avenue

Menlo Park, California

94025 USA

Mr. Andrew Ryan

Cancer Research Campaign

Gray Laboratory

P. O. Box 100

Mt. Vernon Hospital:

Northwood, M1ddlesex. HA6 2JR ENGLAND

Dr. Evelyne sage

Curie Institute

sect. of Biology

26 Rue d'UIm

75005

Paris,

PRANCE

Dr. Alain Sarasin

IRSC

Lab. of Mol. Genetics

UPR 42 C.N.R.S.

B. P. Ho. $8-94801$

Villejuif,

94801 FRANCI:

Dr. Robert H. Schlestl

Harvard University

Dept. of Molecular and

Cellular Toxicology

665 Huntington Avenue

Boston. Massachusetts

02115 USA

Dr. Allce I. Schroeder

Washington State University

Program in Genetics and Cell. Biology

Pullman, Washington

99164-4234 USA
Dr. George C. Roush

Cancer Prevention Research Inst. 36 Bast 22nd Street

New York, New York

10010 USA

Dr. W. Dean Rupp

Yale University

Dept. of Therapeutic Radiology

333 Cedar street

P.0. Box 3333

New Haven, Connecticut

06510 USA

Ms. Vera Sadd1

University of victoria

Dept. of Blology

Centre for Env. Health

R.R. 2, 9865 W. Saanich Road

Sidney. British Columbia

V8L 351 CANADA

Dr. Gwen B. Sancar

Univ. of North Carolina

School of Med.

Dept. of Biochen. \& Blophys.

CD 7260

Chapel Hill, Noxth Carolina

27599-2852 USA

Dr. Koki sato

National Inst. of Radiol. Sci. Div. of Radiation Hazards 4-9-1 Anagawa

260

Chiba,

JAPAN

Dr. David Schtld

Lawrence Berkeley Laboratory

Div. of Cell Mol. Biol.

360 Donner Lab.

Berkeley, California

94720 USA

Dr. Stephen G. Sedgwick

National Inst. for Med. Res.;

Genetics Div.

The Ridgeway, Mill Hill

Sondon,

NW7 1AA ENGLAND


Dr, Michael $M$. Seldman

Otsuka Pharmaceutical Company

9900 Medical Center Drive

Molecular B10l.

Rockville. Maryland

20850 USA

Dr. Barbara C. Setlow

Univ. of Connectlcut Health Ctr. Dept: of Blochenistry

Farmington, Connecticut

06032 USA

Dr. Richarci B. Setlow

Brookhaven National Lab.

B101. Dept.

Upton, New York

11973 USA

Dr. Akihiro Shima

University of Tokyo

Lab. of Racilation Blology

200logical Institute

Faculty of science

Tokyo,

113 JAPAA

Dr. B. Singer

University of California

Donner Laboratory

Berkeley, California

94720 USA

Dr. Hichael J. Smerdon

Washington State Univ.

Blochen. / Blophys. Program

Pullman, Washington

99164-4660 USA

Hs. Amanda Snowden

University of Vermont

Dept. of Pathology

Medical Alumil Bldg.

Burlington, Vermont

05405 USÁ
Dr. Mutsuo sekigueht

Kyushu Univ. Faculty of Med.

1st Dept. of Blochen.

Higashi-ku

Fukuoka,

812 JAPAN

Dr. Peter setlon

Univ. of Connecticut Health ctr.

Dept, of Biochen.

Parmington, Connecticut

06032 USA

Dr. Enily Shacter

Mational Cancer Institute

Libloratory of Genetics

Fildg. 37. Roon 2B03

Bethesda, Maryland

20892 USA

Dr. Michael J. Siciliano

UT H. D. Anderson Cancer Ctr.

Dépt. of Molecular Genetics

Box 045

1515 Holconbe Blvd.

Houston, Texas

77030 USA

Dr. Thomas Richard Skopek

Univ. of North Carolina

Dept. of Path.

Campus Box 7095, Bldg. 236

Chapel Hill, North Carolina 27599 USA

Dr. P. Dennis Smith

Wayne State University

Dept. of Blological sciences

Detrolt, Michigan

48202 USA

Dr. Graciela Splvak

Stanford University

Dept. of Blological sciencis

Stanford, California

94305-5020 USA 
Dr. David L. Springer

Batelle Paciflc Northwest Labs. Blology Chenistry Dept.

Box 999 P7-53

Richland, Washington

99352 USA

Dr. Nat L. Sternberg

DuPont-Merck Pharmaceuticals

DuPont Experimental station

5328/148C

Wilmington, Delawar.

19880-0328 IISA

Dr. Alison C. Stewart

Trends in Genetics

68 H1118 Road

Cambridge,

CB2 ILA ENGLAND

Dr. Bernard 3 . Strauss

University of Chicage

Dept. of Mol. Gen. \& Cell Biol.

920 E. 58th St.

Chicago, Illinols

60637 USA

is

Dr. Kevin S. Sweder

Stanford University

Dept. of Blological sciences

Stanford, California

94305-5020 USA

Dr. David E. Szymkowski

Inperial Cancer Research Fund

Blanche Lane

South Mimms, Potters Bar

Herts,

EN6 3LD ENGLAND

Dr. Kiyoj1 Tanaka

Osaka Univ.

Inst. Ior Mol. Cell. Biol.

565

Osaka,

JAPAN
Dr. Margaret J. Stalker

University of Guelph

Dept. of Pathology

Guelph, Ontario

M1F 2W1 CANADA

Dr. Tinna stevnsner

National Cancer Institute

Lab. of Molecular Pharmacology

Bldg. 37, Room 5C25

9000 Rockville Plke

Bethesda, Maryland

20892 USA

Dr. Bernard $W$. Stewart Univ. of New South Wales Children's Leukemla and Cancer Research Unit Prince of Wales Hospital Randwick, New South Wales 2031 AUSTRALIA

Dr. Betsy M. Sutherland Brookhaven National Lab. B101. Dept.

Upton, New York

11973 USA

Dr. James A. Swenberg

Univ. of North Carolina

Env. Sciences and Engineering

Campus Box 7400

Rosenaw Hall

Chapel Hill, North Carolina 27599 USA

Dr. Bonita G. Taffe

Yational Cancer Institute

Lab. of Human Carcinogenesis

Bldg. 37, Roon 2C22

Bethesda, Maryland

20892 USA

Dr. Moon-shong Tang

UT M. D. Anderson Cancer Ctr.

science Park-Research Division

Dept. of Carcinogenesis

P.O. Box 389

Smithville, Texas 78957 USA 
Dr. Grahan Malcola Taylor

St. Mary'B Hospltal

Inwunogenetics Laboratory

Hathersage Road

Marchester.

M13 OJH ENGLAND

Dr. H1111am D. Taylor

Pennsylvania state Univ.

Dapt. of Mol. \& Cell Biology

464 H. Frear Lab

University Park, Pennsylvania

16803 USA

Dr. Brian D. Thrall

Battelle Pacific Northwest Labs.

Biology \& Chemistry Dept:

Box 999 P7-53

Richland, Washington

99352 USA

Ms. Silvia Tornaletti

Ist. di Genetica Blochimica

ed Fvoluzionistica C.N.R.

Via Abbiategrasso 297

27100

Pavia,

ITALY

Dr. Christine Troelstra

Grasmus Undversity

Raculty of Med.

P. O. Box 1738

Rotterdam, 3000 DR NETHERLANDS

Dr. Sibghat Ullah

Cross Cancer Institute

Dept. of Medicine

Mol. Gen. Lab.

Edmonton, Alberta T6G 122 CANADA

Dr. Bennett Van Houten

University of Vermont

Dept. of Path.

Med. Alumn 1 Bldg.

Burlington, Vermont

05405-0367 USA
Dr. Scott T. Taylor

Bristol-Hyers Squibb Co.

Hicro Molecular Blology

E1. 2100

P.0. Box 4000

Princeton, Hew Jersey

08543 USA

Dr. Larry H. Thompson

Lawrence IIvernore Mational Lab.

Bloned. Sci. Div.

P. 0. Box 5507

Iivermore, California

94550 USA

Dr. Thea D. Tlsty

Univ. of North Carolina

vept. of Pathology, CB 7295

Iineberger Can. Res. Ctr.

Chapel Hill, Horth Carolina

27599-7295 USA

Dr. Ilse I. Tribby

Abbott Laboratories

D-9RM, R1B/7

14th street and sherldan Road

North Chicago, Illinois

60064 USA

Mr. Yvon Trottier

Laval University

Cancer Research Center

l'Hotel-Dieu de Quebec

11. cote du Palais

Quebec, Quebec

$$
\text { GIR } 2 J 6 \text { CAMADA }
$$

Dr. Raul C. Urtasun

Cross Cancer Institute

Dept. of Radiation Oncology

11560 University Avenue

Edmonton, Alberta

$$
\text { T6G } 122 \text { CANADA }
$$

Dr. Juhani A. V1lpo

Tanpere University Hospital

Dept. of Clinical Chemistry

$S E-33520$

Tampere.

FINLAND 
Dr. Rob Visse

Leiden University

Gorlaeus Laboratoriea

Lab. of Molecular Genetics 2300 RA

Leiden, $Z$ H

THE NETHERLANDS

Dr. Robert C. von Borstel

University of Alberta

Dept. of Geneties

Edmonton, Alberta

T6G 2E9

CANADA

Dr. Graham Walker

Massachusetts Inst. of Technology

Dept. of Biol.

Bullding 56-621

77 Massachusetts Avenue

Cambridge, Massachusetts

02139 USA

Dr. Susan 8. Wallace

University of Vermont.

Dept. of Microbiology \&

Molecular Genetics

Given Building

Burlington, Vermont

$\$$

05405 USA

Dr. Yenyun Wang

The Upjohn Company

7228-25-4

301 Henrletta street

Kalamazoo, Michigan

49001 USA

Dr. Qingyi Wei

Johns Hopkins School of Hygiene

$615 \mathrm{~N}$. Wolfe street

P.0. Box 301

Baltimore, Maryland

21205 USA

Dr. Randi B. Weiss

West Virginia University

Dept. of Blology

Brooks Hall

Morgantown, West Virginia

26506 USA
Dr. Michaei R. Volkert

Univ. of Massachusetts Med. Sch.

Dept. of Mol. Gen. \& Microblol.

55 Lake Avenue, Morth

Worcester, Massachusetts

01605 USA

Dr. Evelyn Waldstein

Tel Aviv University

Dept. of Blochenistry

Ramat Aviv.

ISRAEL

Dr. Vernon $\mathbf{s}$. Halker

Univ. of North Carolina

Env. Sclences and Englneering

Campus Box 7095

Chapel Hill, North Carolina

27599 USA

Dr. Y. -H. Eugenia Wang

Lady Davis Inst. for Medical Res.

3755 Cote st. Catherine Road

Montreal, Quebec

H3T $1 E 2$ CAAADA

Ms. Yi-Ching Wang

Michigan State University

Carcinogenesis Laboratory

B620 W. Fee Hall

Lansing, Michigan

48824 USA

Dr. I. Bernard Heinstein

Columbia University

College of Physicians \& Surgecns

Health Scl. Ctr. Bldg.

701 W. 168 th st.

New York, Hew York

10032 USA

Dr. Johannes Westendorf

Univ. Medical School of Hamburg

Department of Toxicology

Grindelallee 117

D-2000

llamburg 13, GRRMANY 
Dr. Iinda M. Western

Syva Company

Research Dept.

H/S 2-208

900 Arastradero

Palo Alto, California

94304 USA

Dr. Thoinas A. Winters

Georgetown University

Dept. of Radiation Medicine

3800 Reservoir Road, N.W.

Washington, District of Columbia

20007-2197 USA

Dr. Roger Woodgate

HICHD, HIH

BIdg. 6, Room $1 A 13$

9000 Rockville Pike

Bethesda, Maryland

20892 USA

Dr. Paul W. Wright

West Virginia University

Dept. of B10logy

123 Brooks Hall

Morgantown, West Virginia

26505 USA

Ms. Yang-Ming Yang

American Health Foundation

Molecular Carcinogenesis Prog.

1 Dana Road

Valhalla, Hew York

10595 USh

Dr. Ronald E. Yasbin

Univ. of Maryland

Dept. of Biol. Sel.

5401 Wilkens Avenue

Baltinore, Maryland

21228 USA
Dr. Gordon F. Whituore

Ontario Cancer Institute

500 Sherbourne st.

Toronto, Ontario

M4X 1K9 CANADA

Dr. Gayle E. Woloschak

Argonne Mational Laboratory

B10l. Med. Research Div.

9700 South Cass Avenue

Argonne, Illinois

60439 USA

Dr. Diane M. Worrad

UMDNJ-SOM

Dept. of Molecular Blology

401 S. Central Plaza

stratford, Hew Jersey

08084 USA

Dr. Philip Wu

University of Vermont

College of Medicine

Dept. of Blochenistry

Given Building

Burlington, Vermont

05403 USA

Dr. Zhi-Jie Yang

Cross Cancer Institute

Molecular Genetics and

Carcinogenesis Lab.

11560 University Avenue

Edmonton, Alberta

T6G 122 CANADA

Dr. Fumio Yatagai

Inst. of Physical \& Chem. Research

Riken Institute

2-1 Hirosawa

351-01

Mako, Saltama

JAPAN 


\title{
Cellular Responses to Environmental DNA Damage
}

\author{
Abstracts of Oral Presentations
}




\section{A Personal Historical View of DNA Repair and Where It Might Go}

R. B. Setlow, Biology Department, Brookhaven National Laboratory, Upton, NY 11973

$\therefore \quad$ DNA repair has its origins in many interacting fields-Genetics, Microbiology, Virology, Photobiology, Photochemistry and Radiation Biology-and has strongly influenced research not only in these fields but also in areas such as Chemical, Radiation and Environmental, Mutagenesis and Carcinogenesis, Biological Effects of Stratosphere Ozone Depletion, Risk Assessment and Aging. One should remember that despite the discovery of bacterial transformation in 1944 and photoreactivation in 1949, it was not until the demonstration in 1952 that the genetic material of bacterial viruses was DNA and the publication of the Watson-Crick base-pairing structure of DNA in 1953 that this polymer was finally accepted as the target of most radiation effects on cells and viruses.

I was a member of the Yale Physics Department and in 1950 joined Emest Pollard's Biophysics Group in the Department. I did experiments on the direct action of ionizing radiation on large molecules and subsequently turned my attention to the effects of UV on proteins. It was unexpected to find out that, for many proteins, the sensitivity to inactivation did not parallel the absorption spectrum, but looked more like the absorption spectrum of cystine rather the aromatic amino acids, indicating that photons absorbed in the former were much more efficacious in altering protein structures than those absorbed by the latter. These findings led me to question the logical basis for assuming that action spectra that looked like nucleic acid absorption-such as for cytotoxicity and mutagenicity in microorganisms - really represented effects on DNA or RNA. The logical basis, did exist because we showed that the action spectrum for crosslinking dry DNA paralleled the absorption spectrum. From then on I and my student collaborators focussed attention on UV effects on viruses and microorganisms-division delay, macromolecular synthesis and the effects of substitution of dThd by BrdUrd.

When I went to the Biology Division of the Oak Ridge National Laboratory in 1960, I joined a staff knowledgeable about nucleic acids, genetics and radiation biology from whom I learned a tremendous amount and among whom I found many collaborators. I also leamed about the discovery of thymine dimers by the Dutch-a finding destined to lead to DNA repair. We were able to measure, by absorbance changes, the action spectra for the formation and splitting of dimers and so were able to design a photochemical technique-dimer splitting by short wavelengths following their formation by long ones-that we used to show that dimers were responsible for a large fraction of the UV-inactivation of bacterial transforming DNA and that they interfered with the actions of DNA polymerase and various nucleases. Moreover, our data indicated that cyclobutane dimers were the only significant substrate for yeast photoreactivating enzyme. Hence, cyclobutane dimers were proven lesions, and it was reasonable to examine their fates in wild type E. coli and in radiation sensitive mutants discovered by Ruth Bill in 1958. Dimers inhibited DNA synthesis in both resistant and sensitive strains but resistant cells recovered the ability to make DNA while sensitive cells did not or did 80 very slowly. In sensitive strains the dimers, labeled with ${ }^{3}$ HdThd, remained in DNA, in resistant strains they 
disappeared from DNA but remained in cells, facilitating their detection, as parts of acid-soluble oligonucleotides. It is noteworthy that excision repair-a general error correcting mechanismwas discovered a year after the aberrant DNA synthesis subsequently called repair replication.

Subsequent efforts by others and myself at Oak Ridge showed excision of UV damage in viruses and in mammalian cells and that the extent of excision increase with species life span. We were led to the design of a technique-the photolysis of BrdUrd incorporated during repairthat was used to estimate patch sizes in repaired regions and to show wide variances in UV instigated DNA repair among fibroblast strains. The latter work has been extended at, Brookhaven in collaboration with Japanese scientists, to include, the $x$-ray sensitivities of fibroblast strains from survivors of the Atomic Bombing. We are also determining distributions of cytogenetic and repair responses among lymphocytes from the apparently normal Brookhaven population. I have participated in two fish stories. The first used photoreactivation to show that dimers in cellular DNA can result in tumors. The second, ongoing, is to measure the wavelengths of light responsible for the induction of malignant melanoma in hybrid fish. The existing genetic information and our dose-response data indicate that UV induction of melanomas arises from the inactivation of a single suppressor in a melanocyte.

I see interesting questions for the future as: Are $\mathbf{C}=\mathbf{T}$ and $\mathbf{T}=\mathbf{T}$ equivalent inhibitors of DNA replication? Does repai in vivo mimic repair in vito for genomic DNA and transcribed DNA? Does repair mediated by exogenously introduced genes have the same linetics as for endogenous genes? Do introduced genes increase lifespan? What are the implications of the large variances in DNA repair among people?

Research supported by the U.S. NIH and by the Office of Health and Environmental Research of the U.S. DOE and its predecessor agencies. 
Cellular Responses to Environmental DNA Damage

Understanding the Causes of Aging and Cancer,

Bruce N. Ames, University of California, Berkeley, CA

Dally endogenous oxidative DNA damage is enormous. A normal young rat . cell has about $10^{\circ}$ oxidative adducts and this number increases with age. Abou: $10^{\mathrm{s}}$ new oxidative adducts per cell are formed every day, most of which are repaired. These are the same sype of adducts that are produced by radiation, an oxidative mutagen. We conclude that endogenous oxidative damage is a major factor in aging and the degenerative diseases associated with aging, such as cancer, heart disease, brain deterioration, and cataracts. He discuss the role of various antioxidants in preventing cancer and the degenerative diseases of aging. We also discuss why mitogenesis is critical for mutagenesis and why agents increasing either mitogenesis or mutagenesis are expected to be carcinogens.

The known and likely causes of cancer are discussed, as well as the contributions of epidemiology and the testing of chemicals in animals to the understanding of causes of cancer in humans. There are large numbers of mutagens and carcinogens in the environment, such as rancid fat, natural toxic chemicals present in all plants as defenses against insects, cooked food, and man-made chemicals, but the meaning of this for human health is not clear as half of all chemicals tested, whether synthetic or natural, are carcinogens in high dose rodent tests. We think this is because high dose animal cancer tests might commonly increase mitogenesis. In the evolutionary war between plants and animals, animals have developed layers of general defenses, almost all inducible, against toxic chemicals. This means we are well-buffered against toxicity at low doses from both man-made and natural chemicals. Low doses of carcinogens (as defined by high-dose rodent tests) appear to be both much more common and less hazardous than is generally thought. 
DNA PHOTOLI ISE: A Multifunctional Enzyme Encoded by a Damage Inducible Gene

\author{
Gwendolyn B. Sancar \\ Department of Biochemistry and Biophysics \\ University of North Carolina at Chapel Hill \\ Chapel Hill, NC 27599-7260
}

In organisms as diverse as bacteria, rattlesnake, marsupials and plants, DNA photolyases play an important role in the ability of cells to withstand the lethal and mutagenic effects of far UV radiation. These enzymes catalyze photoreactivation, the light dependent repair of pyrimidine dimers in DNA. To date genes encoding photolyase apoenzymes have been cloned from 5 bacteria (E. coll, S. typhimurium, S. griseus, A. nidulans, H. halobium) and 2 eukaryotes (S. cerevisiae and $N$. Crassa). The molecular weights of the encoded polypeptides vary from $50 \mathrm{kD}$ to $70 \mathrm{kD}$. Comparison of the amino acid sequences of the photolyases indicates a surprising degree of homology considering the evolutionary distance separating these organisms; fully $15 \%$ of residues are identical, with the carboxy terminal 150 amino acids showing the highest degree of conservation. The functional roles of several of these conserved residues or regions are now known and will be discussed.

As early as 1951 in vivo studies established that, based upon their action spectra, most photolyases fell into one of two groups: those with $\lambda_{\max }$ at $365-405 \mathrm{~nm}$ and those with $\lambda_{\max }$ at $435-445 \mathrm{~nm}$. During the last 5 years it has become apparent that this grouping reflects the presence of different intrinsic chromophores responsible for absorbing most of the light energy used in photoreactivation. Photolyases trom E. coli, S. typhimurium, S. cerevisiae, and N. crassa contain a noncovalently bound pterin chromophore, 5-10-methenyl tetrahydrofolate while the S. griseus, H. halobium, and A. nidulans enzymes contain a deazaflavin chromophore. In addition all photolyases characterized to date contain a second chromophore, FADH 2 . The ubiquitous presence of FADH 2 reflects its central role in the photolysis reaction. Energy absorbed by the primary chromophore is transferred to $\mathrm{FADH}_{2}$ which in its singlet excited state donates an electron to the dimer to initiate repair. FADH 2 is required for photolysis by far UV and visible light, while the primary chromophore serves as "antenna" to increase the photolytic cross section of the enzyine. Recently a third photolyase chromophore has been identified, namely Trp277 (E. coli numbering) which is conserved in all sequenced photolyases. Trp277 photosensitizes repair of pyrimidine dimers by $280 \mathrm{~nm}$ light. While it is doubttul that this contributes significantly to photoreactivation by wavelengths which currently reach the earth's surface, this chromophore may have been important prior to development of the ozone layer. As was originally pointed out by Akira Yasui, certain amino acids are conserved only among the deazaflavin or folate class of photolyases and most of these conserved residues are located in the amino terminal haff of the enzyme. Using proteolysis and gene fusion techniques we have recently shown that this distribution reflects the location of the chromophore binding domains. in S. cerevisiae photolyase FADH 2 binds to a 275 amino acid carboxy terminal domain while whe folate chromophore is bound by a $34 \mathrm{kD}$ amino terminal proteolysis fragment.

Because the intracellular concentration of photolyases is quite low, these enzymes must be able to recognize pyrimidine dimers efficiently within the context of a vast excess of nondamaged pyrimidine nucleotides. The basis of this specificity is the set of dimer specific contacts made by photolyase when it is bound to a pyrimidine dimer in DNA. The primary driving force for specific binding is the interaction of the enzyme with phosphates 5' and '3' to the dimer such that the minimum structure necessary for high affinity specific binding is PT $<$ TpNpNp. The results of DNA footprinting and binding studies indicate that the enzyme approaches the dimer from the major groove and may form $\mathrm{H}$-bonds with $\mathrm{C}(4)=0$ of one or both pyrimidines in the dimer. Some of the amino acids which lie at the DNA binding site have been identified by site-directed mutagenesis and chemical protection techniques. These 
Include Trp277, which appears to be involved in specific binding, as well as conserved Lys and Arg residues.

In addition to catalyzing the light dependent repair of dimers, photolyase also plays a role in nucleotide excision repair of these lesions. E. coli strains carnying a defective phr gene exhibit increased UV-induced mortality compared to wild type when both are held in the dark following irradiation. A similar phenomenon is also seen in S. cerevisiae. In both organisms .. mutations which abolish nucleotide excision repair also abolish the effect. The molecular basis has been established using purified photolyase and subunits of the E. coli ABC excision nuclease: binding of photolyase to pyrimidine dimers enhances both the recognition of dimers by the nuclease and the rate of nuclease turnover. Stimulation is specific for pyrimidine dimers and reflects the preference of photolyase for binding to T-containing dimers. Based upon the known size of the region of DNA protected by yeast photolyase from attack by small chemical probes we can set a limit on the minimum distance between the pyrimidine dimer and the site of incision by eukaryotic riucleotide excision repair nucleases. Yeast photolyase protects 3-4 phosphodiester bonds on each side of the dimer and thus the incision sites must lie at at least this distance.

While the enzymology of photoreactivation is now reasonably well understood, virtually nothing is known concerning the regulation of expression of photolyase-encoding genes. Recently we have begun examining the regulation of the PHR1 gene of S. cerevisiae which encodes the photolyase apoenzyme. We find that expression of PHR1 is induced in response to a variety of DNA damaging agents including $254 \mathrm{~nm}$ radiation, $4 \mathrm{NOO}$, nitrosoguanidine, and methylmethanesulfonate but not by either heat shock or photoreactivating light. Enhanced expression is accompanied by a marked increase in the steady state concentration of PHR1 mRNA, suggesting that transcription of the gene is regulated in response to DNA damage. Using deletion analysis and the band shift assay we have identified a regulatory element and cognate DNA binding protein which are involved in the response of PHR1 to DNA damage. Photolyase Regulatory Protein (Prp) binds to PHR1 $5^{\prime}$ fianking sequences and protects a 39 bp region from attack by copper-phenanthroline. Binding activity is present in nondamaged cells and disappears rapidly following treatment with DNA damaging agents, while deletion of the Prp binding site results in increased basal level expression of PHR1 and diminished induction following damage. In addition the Prp binding site, when placed between the UAS and TATA box of the CYC1 gene confers damage-responsiveness. Thus PRP is a damage-responsive repressor of PHR1 transcription. However full induction of PHR1 requires an additional 5' regulatory element. The response of both elements to multiple damaging agents suggests that they may be involved in the regulation of other damage-inducible genes in yeast. 


\section{DNA DAMAGE RECOGNITION AND PROCESSING BY THE Escherichia coli UVRABC NUCLEASE COMPLEX.}

Ben Van Houten, Amanda Snowden, and Doug Kalinowski.

Department of Pathology, University of Vermont, Burlington, VT 05405.

During the process of nucleotide excision repair in the organism Escherichia coli DNA damage recognition and processing are achieved by the action of the $u v r A$, $u v r B$, and $u v r C$ gene products. Recent progress in several laboratories has helped to develop a molecular model of how these proteins function to recognize and remove damaged nucleotides (1). UvrA consists of several interesting structural motifs, including two zinc-fingers, and two ATP binding sites. In solution the UvrA protein exists as either a monomer or dimer, and the equilibrium is affected by the UvrA concentration, and the presence of ATP and DNA. UvrB is a hydrophobic protein containing a cryptic ATP binding site which appears to become activated when UvrB interacts with UvrA ${ }_{2}$. The UvrA $\mathrm{A}_{2} \mathrm{~B}$ complex has been shown to scan for DNA damage in an ATPdependent manner by melting into the DNA helix, and then translocating in a specific direction altering the topology of the DNA. Once the UvrA $\mathrm{A}_{2} \mathrm{~B}$ complex has encountered a damaged nucleotide, the nucleoprotein complex appears to undergo a conformational change that serves as a recognition signal for the UvrC protein. Concomitantly with UvrC binding, incision of the phosphate backbone occurs at two sites, 7 nucleotides 5' and 4 nucleotides $3^{\prime}$ to the damaged base. The action of the UvrA, UvrB, and UvrC subunits represents a cascade of ordered reactions that first identifies a damaged site, and then marks the site with a tight binding preincision complex and then finally incises the DNA.

Of particular interest to our laboratory are the damage-induced structural alterations which are important for damage recognition, and the nature of the nucleoprotein intermediates that form during the course of these events. In order to systematically address these issues, we have synthesized a series of defined DNA substrates containing abasic sites that have been chemically modified by a series of alkoxyamines containing increasingly larger substituents. It is the goals of this structure-function approach to define specific alterations in the DNA helix leading to a greater binding energy, and to determine whether tighter binding leads to increased incision efficiency. Using incision assays which monitor the conversion of closed circular PM2 DNA to nicked open circle, the overall extent of incision was observed to correlate with the size of the substitution: methyl < ethyl < allyl < benzyl. However, the initial rates of incision did not shown any size correlation. Quantitative DNase I footprinting experiments were used to measure the relative binding energy of the UvrA dimer to a 49 bp duplex containing an apyrimidinic site or a benzoxyamine-modified AP site (2). Surprisingly, the UvrA binding affinity to either substrate was identical $\left(\mathrm{K}_{d}=10-14 \mathrm{nM}\right)$, whereas incision efficiency for the BA containing substrate was much more efficient compared to incision of the AP containing substrate. These results suggested that UvrA binding affinity does not correlate to the incision efficiency. Analysis of the interaction of the Uvr $\mathrm{A}_{2} \mathrm{~B}$ complex with these two substrates revealed a remarkable difference in binding affinities for the BA $\left(K_{d}=4 \mathrm{nM}\right)$ and the AP containing substrates $\left(K_{d}=80-120 \mathrm{nM}\right)$. These data suggest that role of UvTA is to target the repair complex to DNA (providing a discrimination factor of $10^{3}$ ) and the role of the UvrB protein is to modulate the binding affinity for DNA 
lesions by contributing increased specificity and stability to the preincision complex.

Thus, the UvrB subunit acts to precisely identify a damaged site, committing the nuclease complex to incise DNA(3). Gel mobility shift assays were used to confirm the binding affinities and to probe the nature of the protein-DNA interactions which occur during the formation of the preincision complex. The interaction of the $U v r A_{2} B$ complex with the 49 bp BA substrate revealed three intermediates which are consistent with a UvrA - -DNA complex, a UvrA $2 B-D N A$ complex and UvrB-DNA complex. The UvrA $A_{2}-D N A$ complex is very short lived ( $(1 / 2-15$ secs) whereas the UvrA $A_{2} B-D N A$ and UvrB-DNA complexes are long lived (t1/2 - 2 hrs). The UvrA $\mathrm{B}-$ DNA and UvrB-DNA complexes appear to be in equilibrium, and the relative amounts of these complexes is largely dependent on the concentrations of the two proteins, the nature and the amount of substrate and the total DNA concentration. Few, if any UvrB-DNA complexes can be detected on DNA containing AP sites. In addition, a high UvrA to UvrB ratio produce Uvr $A_{2} B-$ DNA complexes exclusively, and result in low incision efficiency. Therefore, the amount of UvrB-DNA complexes directly correlates to the incision efficiency. Two important questions emerge from this work: 1) what are the nature of the protein-DNA contacts which occur during damage recognition?, and 2) what are the structural determinants in the DNA helix that are important for damage recognition? The binding energy of all protein-DNA interactions is a function of electrostatic interactions and hydrophobic interactions such as van der Waals contacts. It is important to consider that the Uvr $\mathrm{A}_{2} \mathrm{~B}$ complex is sampling a dynamic structure as it probes the DNA helix in an ATP-dependent manner for damage-induced structural anomalies. Due to the large repertoire of substrates which do not appear to produce gross alterations in the structure of DNA (1), such as abasic sites, 06-methylguanine, and thymine glycol (4), it has been difficult to elucidate the specific helical alterations which provide favorable contacts and contribute to the binding energy. One feature of the DNA helix that the UvrA $A_{2} B$ complex could use as a sensitive indicator of damaged nucleotides is base-stacking interactions. One prediction of this model is that the formation of the UvrA $\mathrm{B}-\mathrm{DNA}$ complex should be dominated by hydrophobic interactions, a hypothesis which we are currently testing. This model also helps to explain why base mismatches, sequence directed bends and extrahelical bases do not appear to be substrates for the UvrABC nbclease. Future work will be focused on understanding how other cellular factors, such a DNA sequence context, DNA topology and DNA transcription modulate the recognition and incision processes of the UvrABC nuclease complex.

\section{References}

1. Van Houten, B. 1990. Microbilogical Reviews, 54:18-51.

2. Snowden, A., Y.W. Kow, B. Van Houten. 1990. Biochemistry, 29:7251-7259.

3. Snowden, A, and B. Van Houten. 1991. J. Mol. Biol, 220:19-33.

4. W. Kow, S. Wallace, and B. Van Houten. 1990. Mutation Res, 235:147-156. 
The Role of ATP $\Rightarrow$ ADP Equilibria in E.coll Uvr $A_{2} B$ Endonuclease Catalyzed-Reactlons. L. Grossman, B. Ahn, P. Caron, L.Claassen, E. Hildebrand, S.Mazur, K. Mueller, E-Y.Oh, T.Se日ley, S.Thiagalingam and J-T. Wang.

Dept. Biochemistry, The Johns Hopkins School of Public Health, Baltimore, MD 21205

- There are a number of ATP-requiring steps in Uvr-directed incision of damaged DNA. In its essence, our findings to date indicate that the binding of adenine nucleotides "to Uvr proteins is required for association interactions between the proteins or for DNAprotein interactions, whereas, the dissociation of such macromolecular complexes is driven by the hydrolysis of ATP. For example, the energy required for the cimerization of UvrA, the reactive species, is derived from nucleotide binding and is driven to completion by non-hydrolyzable ATP analogs, whereas, monomerization or dissociation reactions require the energy stemming from the hydrolysis of ATP $(1,2)$. Parenthetically, the initial site of nucleoprotein formation is sensitive to the direction of the precursor 2UvrA $\Leftrightarrow$ UvrA2 reaction; hence, association constants for nucleoprotein formation were, surprisingly dependent on the concentration of UvrA (1). Additionally, there are significant topological changes associated with UvrA2-DNA formation which are driven by nucleotide binding (3). The same ATP $\Leftrightarrow$ ADP equilibria affects damage recognition by UvrA (4).

The interaction of UvrB with the UvrA2-DNA complex functions as a 5' $->3^{\prime}$ directed helicase which displaces only short strands in the direction of translocation, and presumably reforms duplexes behind the complex as it progresses $(5,6)$. This translocational mode is accompanied by waves of supercoiling ahead $(t)$ and behind $(-)$ the complex; the rate and extent of which is significantly enhanced by damage (7). This vigorous reaction suggests to us that such a molecular function may merge DNA repair with similar kinds of supercoiling reactions such as those associated with transcription and replication. This is reflected by $a$ unique synergism between RNA polymerase and UvrA2B functioning to be discussed.

Translocation of the UvrA2B complex is driven by ATP or dATP hydrolysis. It is during this tracking process that the UvrA2B complex must presumably sense the presence of damage as it advances unidirectionally. When damaged sites are encountered by the UVrA2B protein complexes DNA binding is stabilized by an increase in association constant by three orders of magnitude (1). We propose that the sensing mechanism is linked to the ATP $\Leftrightarrow$ ADP equilibrium in which the ADP mode supports binding and ATP hydrolysis promotes release of the nucleoprotein interaction for continued sensing cycles. We envision that the "power stroke" driving the vectorial movement ( 8 ) in supercoiling is provided by the cyptic ATPase associated with UvrB of the complex (9-11). A phenotypically wild type UvrB protein has been engineered with a tryptophan substitution at the ATPase active site. Chemical introduction of a fluorescent derivatized cysteine residue elsewhere in the molecule allows for the direct observations of the conformational changes associated with the UVTA2B supercoiling activity monitored by steady state fluorescence and time resolved fluorescence spectroscopy. The relationship between vectorial movements and ATP dependency will be presented within the framework of a model incorporating the ATP $\Leftrightarrow$ ADP equilibrium as controlling that molecular progression along DNA strands. Further, the contribution to damage recognition by the polyhinge region (UvrAsC40) (12) and the helix-tum-helix region of Uvra will be discussed. 


\section{BIBLIOGRAPHY}

1. Mazur, S.J., and Grossmañ, L., Dimerization of Escherichia coll UvrA and its Binding to Undamaged and Uttraviolet Light-Damaged DNA (1981) Biochemistry 30: $4432-4443$

2. Oh, E.Y., Claassen, L. and Grossman, L., ATPase Activity of the UvrA and UvrB Protein Complexes of the Escherichia coll UvrABC Endonuclease. (1989). Nucleic Acids Res. 17, 4145-4159.

3. Oh, E.Y. and Grossman, L., The Effect of Escherichia coll Uvr Protein Binding on the Topology of Supercoiled DNA. (1986) Nucleic Acids Res. 14, 8557-8571.

4. Thiagalingam, S., and Grossman, L., Both ATPase Sites of Escherichia coli have Functional Roles in Nucleotide Excision Repair. (1991) J. Biol. Chem. 266: 11395-11403.

5. Oh, E.Y. and Grossman, L., The Helicase Activity of the Escherichia coll UvrAB Protein Complex.(1987) Proc. Natl. Acad. Sc. U.S.A. 84, 3638-3642.

6. Oh, E.Y. and Grossman, L., Characterization of the Helicase Activity of the Escherichia coll UvrAB Protein Complex. (1989), J. Biol. Chem. 264, 1336-1343

7. Koo, H-S, Claassen, L., Grossman, L., and Liu, L.F.. ATP-dependent, Partitioning of the DNA Template into Supercoiled Domains by Escherichia coli UvrAB (1991). Proc. Natl. Acad. Sci., 88, 1212-1216

8. Jencks, W.P., Rules and the Economics of Energy Balance in Coupled Vectorial Processes (1982) in "Membranes and Transport" Volume 1, Ed. A.N.Martonosi. Plenum Press, NY

9. Caron, P.R., and Grossman,L. Involvement of a cryptic ATPase activity and its proteolysis product, UvrB* in DNA repair. (1988) Nucleic Acids Res. 16, 9651-9662

10.Se日ley, T.W., and Grossman, L., Mutations in the Escherichia coll UvrB ATPase motif compromise excision repair capacity (1989) Proc. Natl. Acad. Sci. U.S.A. 86, 6577-6581.

11.Seeley, T.W., and Grossman, L., The Role of Escherichia coli UvrB in Nucleotide Excision Repair (1990). J. Biol. Chem. 265, 7158-7165..

12. Claassen, L., and Grossman, L., Deletion Mutagenesis of the Escherichia coll UvrA Protein Localizes Domains for DNA Binding, Damage Recognition and Protein-Protein Interactions (1991). J. Biol. Chem. 266:11388-11394

The described research was supported by grants from the National Institutes of Health (GM22846,GM31110) and the Department of Energy (DE-FG02-86ER60396) 
NUCLEOTIDE EXCISION REPAIR (NER) IN EUKARYOTES: RECENT PROGRESS. LEe Bardwelli, A. Jane Cooper ${ }^{1}$, Hanspeter Naegel1 ${ }^{1}$, Wendy $I$. Fle Jter ${ }^{2}$. IIsa D. MCDaniel2, Roger Schultz ${ }^{2}$ and Errol C. Frledberg', Ilaboratory of Molecular Pathology, Department of Pathology, The University of Texas Southwestern Medical Center at Dallas, Dallas IX 75235 and 2D1v1sion of Euman Genetics, University of Maryland, Baltimore, MD 21201.

NTR in eukaryotes is genetically complex, 1nvolving multiple genes whlch have been Ident1fied in yeast, rodent and human cells. Many yeast and human genes have been 1solated by functional cloning and clues about the blochemical functions of the polypeptides they encode are beginning to emerge. In the yeast $S$. cerevisiae at least 7 genes (designated RADI, RAD2, RAD3, RAD4, RAD10, RAD14 and ERCC3sC) are apparently requilred for -arly events in NER, presumably including damage-specific recognition and damage-spectific incision of DNA.

The RAD3 gene encodes a protein of $89 \mathrm{kDa}$ wh1ch 18 a singlestranded DNA-dependent ATPase and DNA hellcase. Using a partially duplex substrate consisting of in 3 circular single-stranded DNA annealed to a radiolabelied 206-mer complementary oligonucleotide, we have demonstrated that the Rad3 DNA hellcase activity is profoundly inhibited by the presence of DNA damage caused by elther uv radiation or cisplatin. In both cases the Inhibition was absolutely strand specific. when DNA damage was confined to the complementary oligonucleotide no inhibition was observed. However, when damage was located on the single stranded circular molecule on which Rad3 protein binds and presumably translocates, 1nhibltion was observed. UV 1rradiation of single-stranded DNA or poly (dT) also results in inhibition of the ability of these polynucleotides to activate the hydrolysis of ATP. Rad3 protein binds strongly to UV Irradiated single stranded DNA, forming stable Rad3protein complexes. Rad3 protein also binds to unirradiated singlestranded RNA but falls to hydrolyze ATP in 1 ts presence. Based on these results we hypothesize that translocation of Rad3 protein is sensitive to alterations in the chemistry of DNA, resulting in inhibition of ATP hydrolysis and of DNA unwinding. This phenomenon may be an important determinant for damage-specific recognition during NER in yeast. Rad3 proteln is also an DNA.RNA hellcase, but does not unwind partially duplex ribonucleot1de homopolymers.

Rad1, Rad2, Rad3, Rad4 and Radlo protelns have been expressed in an in vitro transcription-translation system. This system offers the potential for examining specific protein-protein and protein-DNA interactions. Using a partially purified in vitro transiation system enriched for radiolabelied Rad protelns, we have demonstrated that Rald protein forms stable complexes with Radro protein in solution in the absence of DNA.

Studies in several laboratories have identifled human genes which correct mutant cellular phenotypes in human hereditary disealses defective in NER. In some cases yeast homologs for these genes ure known. Using the technlque of microcell-mediated chromosame transfer we have isolated a single rearranged human chromosome which specifically corrects both UV radiation sensitivity and defective NER In XP group D cel18. Detalled molecular and cytogenetic characterlzation of this chromoscme revealed a complex rearrangement 1nvolving chromoscmes 16, 17 and 19. The complementing region of this chromoscme has been localized to the region 19q13.2-13.3, a region known to contain a repalr gene cluster. Transfection of XP-D cells with a cosmld contalning the human ERCC2 gene corrects the UV sensitivity of XP-D cells. 
For AACR Special Conference, Banff; December 1991 Cellular Responses to Environmental DNA Damage Plenary Session I

Fine Structure of DNA Repair in the Mammalian Genome

\author{
Philip C. Hanawalt \\ Department of Biological Sciences, Stanford University, Stanford, California 94305-5020 USA
}

The biological consequences of damaged DNA depend upon the intragenomic locations of the lesions. Damage at specific sites in the mammalian senome leads to mutation, recombination, zene amplification, translocation, and other chromosomal abnormalities. These changes may result in malignant transformation, faulty differentiation patterns, or cell death. Thus, damage to DNA at particular loci can aullify tumor suppressor genes or activate protooncogenes that may be implicated in subsequent tumorigenesis. In certain human genetic diseases a defect in the processing of damaged DNA correlates with an increased incidence of neoplasia.

Both the introduction and the repair of some types of DNA lesions are heterogeneous with respect to chromatin structure and/or gene activity $(1,2)$. For example, cyclobutane pyrimidine dimers (CPD) are more efficientlyremoved from an active than a silent protooncogene in UV irradiated mouse cells (3). The preferential repair of CPD in the transcribed strands of expressed genes results in a bias toward mutagenesis from the persisting CPD in the non-transeribed strands (2). Differential introduction and repair of psoralen photoadducts occurs in active vs. silent human genes (4), and the intrastrand crosslinking is removed more efficiently than are the monoadducts from an expressed gene (5). Persisting damage in non-transcribed domains may lead to genomic instability in those regions, particularly during cell proliferation as lesions are encountered by replication forks. Differences in the repair response to damage in specific genomic regions could account for some of the profound differences in tumor susceptibility in different tissues or when different organisms are compared. It is therefore important to learn the fine structure of DNA damage processing in protooncogenes and other DNA sequences that may be implicated in tumorigenesis.

The cancer-prone phenotype of xeroderma pigmentosum (group C) correlates with a deficiency in repair of unexpressed DNA sequences while in Cockayne's syndrome (also characterized by sunlight sensitivity) a defect in the preferential repair of expressed genes is not accompanied by cancer susceptibility (6-8). In rat myoblasts, differentiating to myotubes, overall DNA repair levels are attenuated while some expressed, tissue-specificgenes are selectively repaired (9). These terminally differentiating cells seem to maintain DNA damage surveillance and repair capacity for selected genes and/or genomic domains. In human HL60 promyelocytic cells repair in the c-myeprotooncogene is markedly reduced as transcription is down-regulated during differentiation to macrophages (Islas and Hanawalt, unpublished). Sometimes an apparent overall deficiency in repair of CPD does not hold up at the level of specific DNA sequences in expresesd senes (10).

The generality and importance of strand-specific repair is affirmed by its operation in $E$. coli (11) from which a transcription-repair coupling factor has now been partially purified by Selby and Sancar (12).

A general conclusion from the documented examples of intragenomic heterogeneity in DNA damage and repair is that attempts to correlate biological endpoints with overall genomic DNA repair levels may not lead to meaningful conclusions. The repainbility of damage depends not only upon the type of lesion but also upon its chromosomal location and the anture of gene expression at that site.

Hanawalt, P.C; Banff abstract. 1 page of 2. 
Referencer:

1. Bohr VA, Phillips DH, and Hanawalt PC "Heterogeneous DNA damage and repair in the mammalian genome" Cancer Research 47:6426-6436(1987)

2.- Smith CA and Mellon I "Clues to the organization of DNA repair systems gained from studies of intragenomic repair heterogeneity" in Advances in Mutagenesis Research. (ed G Obe) Springer-Verlag, Berlin, Vol 1, pp 153-194(1990)

3. Madhani HD, Bohr VA, and Hanawalt PC "Differential DNA repair in a transcriptionally active and inactive protooncogene: $c$-abland c-mos" Cell 45:417-422(1986)

4. Islas A, Vos J-M H, and Hanawalt PC "Differential introduction and repair of psoralen photoadducts to DNA in specific human genes" Cancer Research 51:2867-2873(1991)

5. Vos J-Mand Hanawalt PC "Processing of psoralen adducts in an active gene: repair and replication of DNA containing monoadducts and interstrand cross-links" Cell 50:789-799(1987)

6. Kantor GJ, Barsalou LS, and Hanawalt PC "Selective repair of specific chromatin domains in UV irradiated cells from xesoderma pigmentosum complementation group C' Musation Research:DNA Repair 235:171-180(1990)

7. Venema J, Mullenders LHF, Natarajan AT, van Zeeland AA, and Mayne LV "The genetic defeet in Cockayne syndrome is associated with a defect in repair of UV-induced DNA damage in transcriptionally active DNA" Proc Nasl Acad Sci USA 87:4407-4711(1990)

8. Venema J, van Hoffen A, Natarajan AT, van Zeeland AA, Mullenders LHF "Xeroderma pigmentosum complementation group $C$ cells remove pyrimidine dimers selectively from the transcribed strand of active genes" Molec Cell Biol 11:4128-4134(1991)

9. Ho I and Hanawalt PC. "Gene-specific DNA repair in terminally differentiating rat myoblasts." Mulation Research:DNA Repair 255:123-141(1991).

10. Lommel $L$ and Hanawalt PC "The genetic defect in the Chinese hamster ovary cell mutant UV61 permits moderate selective repair of cyclobutane pyrimidine dimers in an expressed gene" Mutation Research: DNA Repair 255:183-191(1991)

11. Mellon I and Hanawalt PC "Induction of the Escherichia coli lactose operon selectively increases repair of its transcribed DNA strand" Nature 312:95-98(1989)

12. Selby CP and Sancar $A$ "Gene- and strand-specific repair in vitro: Partial purification of a transcription-repair coupling factor" Proc Niatl Acad Sci USA 88:8232-8236(1991)

Hanawalt, P.C.; Banff abstract. 2 page of 2. 
A NEW RUNAN REPAIR PROTEIN RECOGIIZING A BUTKY ADDOCT B. Singer, M.X. Dosanth, 2.-B. Oul and B. Rydberg Donnez Laboratory, Lawrance Berkeley Laborafory, Unlveralty of Callforisa, Derkeley, CA 94720

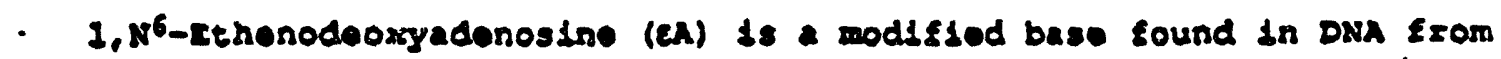
arianis trouted with olnyl chlosido, a known buman carcinogon. Repads of this - Or other vinyl obloride cyclie derlvatives has not been roported. Using a aynthotio oligonuoleotide oontaining ologle on annealed to tho normal complementary sequenco, varlety of buman tlssues and colle ware lound to apoeisleally blind to the adduet. Nleklng producod two lragments, 3' and 5' to the adduct. The partialiy purifiod extracts were also used for studies of binding conerents and the rates of reloase of the produets. Proliminary data

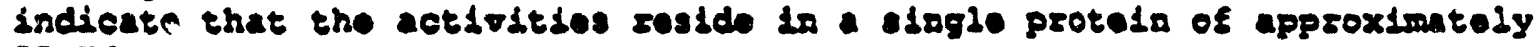
35 Ra.

Interest1ng2y, both $8 . c 011$ and youst apparently lack tho binding and nick1ng activitles. However, rat 1 liar extraet was not lound to bind, using gel rotardation assay, but did eleave the oldgonuelootlde indlarly to the human psotoln. Thus ndcklng may bo a more cceurete masure of enzyme actlolty than "olrding, luing a gel gatardation asary. Boveral modifled ollgonuelootidos or WNa, contaloling spoolfto adduote, whon lncubated with the active mamnelien oxtracts and the en-011gomer, were lound to be compet1tors, both lor blinding and aleking. The range of adducte tooted in thio manner indicates that the

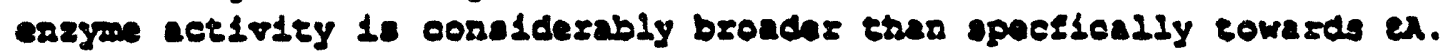


Enzymatic repair of $0^{6}$-methylguanine and elimination of 8-oxoguanine-containing nucleotide

M. Sekiguchi, H. Hayakawa and H. Maki

Department of Biochemistry, Faculty of Medicine, Kyushu University, Fukuoka 812, Japan

Organisms come equipped with elaborate mechanisms that keep mutation rates low. There are several steps required to prevent errors during DNA replication. Here we report functions of two proteins involved in prevention of occurence of induced and spontaneous mutations.

Alkylating agents are potent mutagens and carcinogens and sometimes cause cell death. These effects of alkylating agents are mainly attributed to the formation of various alkylated bases in DNA, among which $0^{6}$-methylguanine is most notable as a mutation-inducing lesion. Many organisms possess an enzyme, $0^{6}$. methylgaunine-DNA methyltransferase that repairs 06 . methylguanine in DNA. It transfers a methyl group from $0^{6 .}$ methylguanine in methylated DNA to a cysteine residue of the enzyme molecule, thereby removing the toxic lesion in a single-step reaction. From various prokaryotic and eukaryotic organisms genes or cDNAs for the methyltransferases have been cloned and their nucleotide sequences determined.' In the 9 molecular species of enzymes, derived from bacteria through human cells, the cyteine residue accepting a methyl group from $0^{6}$-methylguanine of DNA is located within the sequence -Pro-Cys-His-Arg-Val/lle-. To establish roles of the conserved amino acid sequences, we have constructed various mutant forms of protein by site-directed mutagenesis and examined their activities and stabilities both in vivo and in vitro.

Errors in the replication of DNA are a major source of spotaneous mutations, and a number of cellular functions are involved in correction of these errors to maintain the frequency of spontaneous mutations very low. We recently found a novel mechanism which prevents replication errors by degrading a potent mutagenic substrate for DNA synthesis. This error-avoiding process is catalyzed by a protein coded by the mutT gene of Escherichia coli, mutations of which increase the occurrence of AT to CG transversions 100 to 10,000 -fold the wild type level. 8-Oxo dGTP, which is formed by spontaneous oxidation of dGTP, is inserted opposite $\mathrm{dA}$ and $\mathrm{dC}$ residues of template DNA with almost equal efficiencies, and the MutT protein specifically degrades 8-0xo dGTP to monophosphate. These findings indicate that elimination from the nucleotide pool of the oxidized form of guanine nucleotide is important for the high fidelity of DNA synthesis. 
To elucidate the roles of these enzymes in preventing cancers, it is necessary to construct animal models with altered levels of the enzyme activities. Studies along this line are in progress.

\section{REFERENCES}

H. Hayakawa, G. Koike and M. Sekiguchi : Expression and cloning of complementary DNA for a human enzyme that repairs 06 . methylguanine. J. Mol. Biol. 213, 739-747(1990)

G. Koike, H. Maki, H. Takeya, H. Hayakawa and M. Sekiguchi : Purification, structure, and biochemical properties of human 06-methylgaunine-DNA methyltransferase. J. Biol. Chem. 265, 14754-14762(1990)

A. Akiyama, H. Maki, M. Sekiguchi and T. Horiuchi : A specific role of MutT protein : To prevent dG dA mispairing in DNA replication. 'Proc. Natl. Acad. Sci. U. S. A., 86, 39493952(1989)

H. Maki and M. Sekiguchi : MutT protein specifically hydrolyzes 8oxodGTP, a potent mutagenic substrate for DNA synthesis. Nature (in press) 
Bacterial Spore Photochemistry Revisited

\author{
Peter Setlow \\ Department of Biochemistry \\ University of Connecticut Health Center
}

Farmington, CT 06030

Over 25 years ago Donnellan and Setlow (senior) reported a novel observation concerning the UV photochemistry of DNA in dormant spores of Bacillus species (Science, 149:308-310 (1965)). They reported that UV irradiation of ${ }^{3} \mathrm{H}$-thymidine labeled spores produced no detectable cyclobutane type thymine dimers (TT), but rather a different product, originally called spore photoproduct (SP) and later shown to be a 5-thyminyl-5,6dihydrothymine adduct. Formation of SP instead of TT upon UV irradiation is the reason spores are more UV resistant than growing cells, because there is a specific, and evidently efficient, system for SP repair which operates early in spore germination. We (P. Setlow (junior), B. Setlow (in-law junior), W. Nicholson and H. Fairhead) have found that the novel UV photochemistry of dormant spore DNA is due in large part to its association with a group of small, acid-soluble spore proteins (SASP) of the $\alpha / \beta$-type. The $\alpha / \beta$-type SASP are synthesized only during sporulation within developing spores of both Clostridium and Bacillus species, and are rapidly degraded during spore germination. $\alpha / \beta$-Type SASP are found at high levels (4-7\% of total protein) in spores of all Bacillus and Clostridium species, and their primary sequence has been very highly conserved throughout evolution. Their amino acid sequences show no significant homology with other sequences in available data bases. Absence of $\alpha / \beta$-type SASP from Bacillus subtilis due to deletion of appropriate genes results in spores which are UV sensitive and in which TT is generated upon UV irradiation. We have purified $\alpha / \beta$-type SASP from spores of a number of species, and have found that they are DNA binding proteins, all with a marked specificity for DNA which can readily enter the A-conformation. Indeed, we have found that addition of $\alpha / \beta$-type SASP to a number of DNAs results in a conformational change to an A-like structure in the DNA. UV irradiation in vitro of DNA such as plasmid pUC18 complexed with any $\alpha / \beta$-type SASP tested produces no TT, but does generate SP. Similarly, irradiation of polydG.polydC complexed with $\alpha / \beta$-type SASP produces no cytosine dimers, and irradiation of poly (dA-dG).poly (dC-dT)-SASP complexes produces no significant amount of any photoproduct, including cytosine-thymine dimers and possibly the 6-4 addition product. It appears likely that the binding of spure DNA by $\alpha / \beta$-type SASP, a new type of DNA binding protein, explains in large part the resistance of bacterial spores to UV irradiation, and the novel UV photochemistry of their DNA.

It is a pleasure to acknowledge the advice of both Jane $\mathrm{K}$. Setlow and Richard B. Setlow in this work. This research has been supported by grants from the Army Research Office and the National Institutes of Health (GM19698). 
INDUCTION AND REPAIR OF CLOSELY-OPPOSED, CYCLOBUTYL PYRIMIDINE DIMEERS

Richard J. Reynolds
$\quad$ Life Sclences Division, Los Alamos National Laboratory
P.0. Box 1663, Los Alamos, New Mexico, 87545, O.S.A.

$\therefore \quad$ Lesions affecting both strands of a DNA double-helix complicate repair processes and generally have greater biological impact than similar alterations involving only one of the two complementary strands. These conclusions have been deduced laxgely from studies on DNA-DNA interstrand crosslinks, double-strand breaks and thelr monofunctional counterparts. Closely-opposed base damage has also been the subject of considerable speculation. Unt1l recently, however, studies on these topologically complex lesions have been hindered by the absence of sultable assays, and relatively 11ttle is actually known about their Induction, repair or biological significance.

To address these problems we have, as have so many before us, chosen UV. Induced, cyclobutyl pyrimidine dimers as model DNA lesions. The development of sultable assay systems for the detection of closely-opposed dimers has been possible due to the specificity of pyrinidine dimer (PD)-DNA glycosylase, prepared from Micrococcus Iuteus. In these assays PD-DNA glycosylase is used to make single-strand incisions at pyrimidine dimers. There diners occur in each of the two complementary strands of a single DNA double-helix and at positions separated by no more than a few base pairs, cleavage at both positions is effectively expressed as a double-strand break. Thus, closelyopposed dimers are detectable as enzyme-sensitive sites (ESS) expressed under nondenaturing assay conditions. We refer to ESS detected in this way as bifilar ESS both to indicate the Indirect nature of these assays and to distinguish events expressed under nondenaturing conditions from those detected upon DMA denaturation (6).

A primary concern in bifilar ESS assays is the nature of sites detected. The sensitivity of UV-Induced, bifilar ESS to enzymatic photoreactivation demonstrates that pyrimidine dimers are involved in most if not all bifilar ESS detected in UV-Irradiated DNAs. This has been confirmed by DNA sequence analysis (4). Furthermore, DNA sequence analysis of sites contributing to the formation of bifllar ESS has demonstrated that they are indicative of closelyopposed dimers separated by no nore than, and probably less than, 15 base pairs under our standard assay conditions (4). A nore precise analysis of factors affecting the detection of closely-opposed diners as bifilar ESS should be possible with synthetic oligodeoxynucleotide assays currently under developnent.

Blfilar ESS assays, employing velocity sedimentation through neutral sucrose gradients, have been used to examine the induction of closely-opposed diners in a number of biological systens. These sites are induced as apparently linear function of dose in both Escherichia coli (1) and saccharouryces cerevisiae (5), and as somewhet more couplex functions of dose In cultured human fibroblasts ( 3 ) and Chinese hamster ovary (CHO) cells (Reynolds, unpublished results). None of these relationships fit simple "twohit" models traditionally used to test the contribution of closely-opposed dimers to the biologic effects of UV radiation. Furthermore, any nore sites are observed at low doses in each system than would be predicted by these theoretical node1s. The larger than expected numbers of bifilar Ess induced by low UV doses do not appear to result elther from unexpected endonucleolytic activity in the PD-DMA glycosylase preparation or from synergistic 
interactions favoring dimer Induction at closely-opposed positions (2). Synthetic oligodeoxynucleotides are currently being employed to examine the effects of DNA sequence on closely-opposed diner Induction in more detall:

Explanations for discrepancies between the predictions of theoretical models and empirical results with bifllar ESS assays have been revealed through DNA sequence analysis of the sites forming bifilar ESS. Theoretical adels routinely assume an absence of overlapping domains for closely-opposed diner Induction and an equal probability for diner Induction at all sites contributing to the formation of closely-opposed diners. Nelther of these assumptions is supported by DMA sequence analysis. Bifilar ESS are induced preferentially at altes comprised of closely-opposed pyrimidine runs and closely-opposed pyrimidine pairs devold of overlapping domains for closelyopposed dimer induction are relatively rare in native DNAs (4).

Sedimentation-based, bifilar ESS assays have also been employed to examine the repair of closely-opposed diners in eukaryotic cells. (The interpretation of repair results is complex. For a detailed discussion of this topic, see ref. 6). Closely-opposed dimers are sensitive to repalr by enzymatic photoreactivation in $S$. cerevisiae (5) and by excision repair in both $S$. cerevislae (5) and human fibroblasts (3). Their repair in chO cells, however, Is mediated primarily by a process that depends upon semiconservative DMA synthesis and is independent of excision-repair capacity (Reynolds, unpublished results). This latter process is consistent with some form of transiesion synthesis or postreplication repair operating at closely-opposed divers.

Although significant progress is now being made towards an understanding of the processes associated with the induction and repair of closely-opposed diners, studies on their blological effects are In their infancy. Such studies would be greatly facliltated by the ability to examine either isolated or closely-opposed dimers in the absence of the other. This might be possible in namalian cells with shuttle vectors and the sultability of such systems is currently under investigation.

The author gratefully acknowledges the any contributions to this project that have been aade by DE. Lun H. Lam, Dr. Jac A. Nickoloff and Ms. IIsa N. Spirio.

Support for this research has been provided by Public Health Research grants ROI 33949, RO1 42390 and RO1 55019 from the J.S. National Institutes of Health. Research at Los Alamos National Laboratory is conducted under the ausplces of the U.S. Departwent of Energy.

\section{REFERENCES}

1) Andreev, O.A. and N.v. Tonilin. 1980. Stud. Blophys. 78: 223-231.

2) Lam, L.H. and R.J. Reynolds. 1986a. Biophys. J. 50: 307-317.

3) Lam, L.H. and R.J. Reynolds. 1986b. Mutation Res. 166: 187-198.

4) Lam, L.H. and R.J. Reynolds. 1987. Mutation Res. 178: 167-176.

5) Reynolds, R.J. 1987. Mutation Res. 184: 197-207.

6) Reymolds, R.J. and L.H. Lan. 1988. In: DNA Repair: A Laboratory Manual of Resenrch Procedures, Vol. 3 (E.C. Friedberg and P.C. Hanawalt, eds.), Marcel Dekker, Inc, N.Y., Pp. 427-442. 
Excision Repair at the DNA Sequence Level in the Genome:

Why does sunlight induce p53 mutations in skin cancer?

Douglas E. Brash, Subrahmanyam Kunala, Annemarie Ziegler, and Jeffrey A. Simon. Department of Therapeutic Radiology, Yale School of Medicine, New Haven, CT 06510

Of the various UV photoproducts, which lead to cancer in humans? Experimental intervention is precluded; moreover, we wish to know what did happen, rather than what can be made to happen. Pursuing the question must thus be a detective story.

Since carcinogenesis evidently requires mutagenesis, we first identified a gene in human skin wumors in which photoproducts had left the distinctive mutational signature of UV: a high frequency of $C \rightarrow T$ substitutions at adjacent pyrimidines, including CC $\rightarrow$ TT doublebase changes. In invasive squamous cell carcinoma of the skin, one such gene was the p53 tumor suppressor gene, which was mutated in (58\%) of tumors (1). Each mutation altered the amino acid sequence. The spectrum of base changes differed from that found in p53 in internal malignancies.

\begin{tabular}{|c|c|c|c|c|}
\hline Site & Coton & Sequence & Base Change & Amino Acid Change \\
\hline $\begin{array}{l}\text { preauricular } \\
\text { chest } \\
\text { preauricular } \\
\text { temple } \\
\text { scalp } \\
\text { hand } \\
\text { front scalp } \\
\text { cheek } \\
\text { chest } \\
\text { nose } \\
\text { side of face } \\
\text { cheek } \\
\text { tace } \\
\text { forehead } \\
\text { postauricular }\end{array}$ & $\begin{array}{c}7 \\
56 \\
104 / 105 \\
104 / 105 \\
151 \\
152 \\
179 \\
245 \\
245 \\
247-248 \\
258 \\
278 \\
285-286 \\
286 \\
317\end{array}$ & 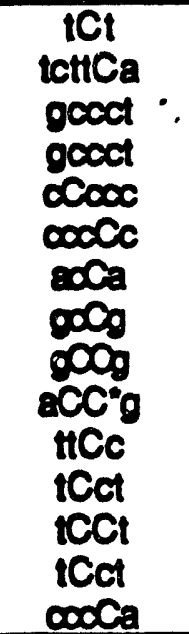 & $\begin{array}{c}C \rightarrow G \\
C \rightarrow A \\
\Delta C \\
\Delta C \\
C \rightarrow A \\
C \rightarrow T \\
C \rightarrow A \\
C \rightarrow A \\
C C \rightarrow T \\
C C \rightarrow T \\
C \rightarrow T \\
C \rightarrow T \\
C C \rightarrow T \\
C \rightarrow T \\
C \rightarrow T\end{array}$ & $\begin{array}{c}\text { Asp } \rightarrow \text { His } \\
\text { Glu } \rightarrow \text { stop } \\
\text { Gly } \rightarrow \text { Ala ... stop } \\
\text { Gly } \rightarrow \text { Ala ... stop } \\
\text { Pro } \rightarrow \text { His } \\
\text { Pro } \rightarrow \text { Ser } \\
\text { His } \rightarrow \text { Asn } \\
\text { Gly } \rightarrow \text { Cys } \\
\text { Gly } \rightarrow \text { Asn } \\
\text { AsnAro } \rightarrow \text { AsnTrp } \\
\text { Glu } \rightarrow \text { Lys } \\
\text { Pro } \rightarrow \text { Sor } \\
\text { GluGlu } \rightarrow \text { GluLys } \\
\text { Glu } \rightarrow \text { Lys } \\
\text { Gln } \rightarrow \text { stop }\end{array}$ \\
\hline
\end{tabular}

The prevalence of mutations at the $\mathrm{C}$ of a dipyrimidine site implicates dipyrimidine photoproducts containing cytosine as oncogenic photoproducts. These include the TC, $C T$, and CC cyclobutane pyrimidine dimers, the TC and CC (6-4) photoproducts, and the Dewar isomers of the (6-4) photoproducts (2). The cytosine-containing cyclobutane dimers were previously implicated in UV mutagenesis in human cells (3). In one of the skin tumors, the mutation occurred at a 5-methylcytosine, identified with an *. Since 5MeC blocks (6-4) photoproduct formation (4), the carcinogenic photoproduct in this wor was most likely a CC cyclobutane pyrimidine dimer. 
The non-melanoma skin cancens, which approach the frequency of all other tumors combined, include basal cell carcinoma as well as squamous cell carcinoma. BCC is 5-fold more frequent than SCC, but it does not metastasize. Does BCC also involve p53 as a sunlight-related step in carcinogenesis? So far, we find that at least $50 \%$ of BCC have p53 mutations, and these mutations are again UV-related. Combining the data from BCC and SCC reveals four mutation hotspots; one of these is not a hotspot in internal malignancies.

To learn what determines the location of these sunlight-induced p53 mutations, we would like to measure UV photoproduct frequencies at the DNA sequence level in the keratinocyte's genomic DNA. We would also like to know whether excision repair is uniform at all bases, or whether there are repair "slow-spots."

We are addressing such questions in the $E$. coli lad gene, by end-labeling a specific gene in genomic DNA. Sites and frequencies of photoproducts can be identified by photoproductspecific incision (5). On the non-transcribed (top) strand of GM1, at $40 \mathrm{~J} / \mathrm{m}^{2}$, excision rates for cyclobutane dimers are slow. In contrash, excision is much faster on the transcribed (bottom) strand, with the exception of a 4-nucleotide "slow-spot" At this site, excision is almost as slow as on the non-transcribed strand. This slow-spot includes sites U6 and A2A, which are among the few mutation hotspots on the transcribed strand of lacI (6). It has previously been proposed that this site is at the end of a haipin loop (7).

\begin{tabular}{llllllll}
\hline & \multicolumn{2}{c}{ Site } & Sequence & 0 & 10 & 20 & 30 min \\
\hline $\begin{array}{l}\text { Non-transcribed } \\
\text { (top) strand }\end{array}$ & 7058 & (A23) & $T C$ & $100 \%$ & $90 \%$ & $92 \%$ & $87 \%$ \\
& 741 & (O27) & $\pi$ & 100 & 72 & 64 & 51 \\
& & $\pi$ & 100 & 76 & 52 & 51 \\
\hline Transcribed & 672 & $\pi$ & 100 & 52 & 16 & 10 \\
(bottom) strand & 678 & $\pi$ & 100 & 30 & 10 & $<10$ \\
& 679 & $\pi$ & 100 & 24 & 10 & $<10$ \\
& 689 (U6) & $\pi$ & 100 & 80 & 46 & 31 \\
& 712 & $\pi$ & 100 & 41 & 13 & 11 \\
\hline
\end{tabular}

\section{REFERENCES}

1. Brash, D. E., Rudolph, J. A., Simon, J. A., Lin, A., McKenna, G. J., Baden, H. P., Halperin, A. J. \& Pontén, J. (1991) Proc. Natl. Acad. Sci. USA. in press.

2. Brash, D. E. (1988) Photochem. Photobiol. 48: 59-66.

3. Brash, D. E., Seetharam, S., Kraemer, K. H., Seidman, M. M. \& Bredberg, A. (1987) Proc. Natl. Acad. Sci. USA. 84: 3782-3786.

4. Glickman, B. W., Schaaper, R. M., Haseltine, W. A., Dunn, R. L。 \& Brash, D. E. (1986) Proc. Natl. Acad. Sci. USA 83: 6945-6949.

5. Brash, D. E. (1988) in DNA Repair: A Laboratory Manual of Research Procedures, ed. Friedberg, E. C. \& Hanawalt, P. C. (Marcel Dekker, New York), pp. 327-345.

6. Koehler, D. R., Awadallah, S. S. \& Glickman, B. W. (1991) J Biol Chem 266: 11766-73.

7. Todd, P. A. \& Glickman, B. W. (1982) Proc. Natl. Acad. Sci. USA 79: 4123-4127. 
Cellular Responses to Environmental DNA Damage

\section{ANIMAL MODELS IN PHOTOBIOLOGY}

Ronald D. Ley, Center for Photomedicine, Lovelace Medical Foundation, 2425 Ridgecrest Drive, SE, Albuquerque, New Mexico 87108 USA.

Numerous animal species have been used during the last six decades to study the detrimental effects of ultraviolet radiation (UVR) on mammalian skin and eyes. Roffo ${ }^{1}$ (1934) used white rats to show that window-glass filtration which efficiently removed wavelengths below $320 \mathrm{~nm}$ also eliminated the photocarcinogenic potency of sunlight. Since this early study which roughly identified those wavelengths most effective at inducing pathologic changes in mammalian skin, a tremendous amount of information has been generated, primarily with murine models, on action spectra, dose-resnonse relationships and time course for formation of a number of photodermatologic endpoints including erythema, edema, sunburn cells, immune suppression and tumor formation.

Identification of a role for a specific photoproduct in pathologic changes required the use of unique animal models which possess the capacity to photoreactivate selectively UVRinduced pyrimidine dimers in DNA. Fish and marsupials have photoreactivation repair and have been used to identify the involvement of pyrimidine dimers in the induction of nonmelanoma and melanoma cancers. Photoreactivation is a DNA repair pathway that requires the presence of a photoreactivation enzyme (photolyase) which recognizes and binds specifically to pyrimidine dimers in DNA Illumination of the photolyase-dimer complex with wavelengths in the range of $300-500 \mathrm{~nm}$ results, upon absorption of a photon, in the conversion of dimerized pyrimidines to their monomeric form. Photoreactivation in the Amazon molly, Poecilia formosa, and in a platyfish-swordtail hybrid has been used to suppress UVR-induced neoplastic transformation ${ }^{2}$ and melanoma formation ${ }^{3}$, respectively. Similarly, in the marsupial, Monodelphis domestica, photoreactivation delayed the time to appearance and incidence of nonmelanoma and melanoma ${ }^{4}$ skin tumors. Corneal tumor formation in this animal also was inhibited by photoreactivation repair. ${ }^{4}$ Photoreactivation has also been used in Monodelphis to suppress the capacity of UVR to induce erythema, edema, desquamation, sunburn cells, hyperplasia, loss of ATPase ${ }^{+}$Langerhans cells, immune suppression and opacification and neovascularization of the comea.

These studies indicate that DNA photoproducts, or more specifically pyrimidine dimers, are in some way involved in the appearance of a number of pathologic changes in acutely- and chronically-irradiated skin and eyes.

${ }^{1}$ Rofio, AH. Bull, Assoc. Franc Etude Cancer, 23, 590. 1934.

'Hart, R.H., Setlow, R.B. and Woodhead, A.D. Proc. Nath Acad. Sci, 74, 5574, 1977.

${ }^{3}$ setlow, R.B., Woodhead, A.D. and Grist, E. Proc. Nath Acad. Sci, 86, 8922, 1989.

Ley, R.D., Applegate, LA., Fry, RJ.M. and Sanchez, A.B. Cancer Res, In press.

SLey, R.D., Applegate, LA, Padilla, R.S. and Stuart, T.D. Photochem. Photobiol 50, 1, 1989. 


\section{Strategies for Repair of UV Damage}

in Human Skin in situ

Betsy M. Sutherland', Paula V. Bennett', Haim Hacham', Richard W. Gange and John C. Sutherland', 'Biology Department, Brookhaven National Laboratory, Upton NY, 11973 USA $\because$ and 'Wellman Laboratories, Department of Dermatology, Harvard Medical School, Boston, MA 02114 USA

Repair of UV damage to DNA in human skin in situ differs quantitatively and qualitatively from that measured in human skin cells in culture. First, normal sunlight exposures which do not kill cells in skin induce high levels of photoproducts which would be lethal to skin cells in culture. For example, 2 MEDs (minimal erythemal doses) of UVB can induce 200 pyrimidine dimers/megabase in DNA of human skin. This roughly equals a dose of $33 \mathrm{~J} / \mathrm{m}^{2}$ of $254 \mathrm{~nm}$ radiation, and can be compared to a $D_{10}$ for $254 \mathrm{~nm}$ of about $8 \mathrm{~J} / \mathrm{m}^{2}$ for survival of normal human cells. UVA, which comprises a large portion of the sunlight spectrum, also produces significant levels of dimers in human skin, about $6 / \mathrm{Mb} / \mathrm{MED}$. Thus such a person who was exposed to 2 MED of sunlight would initially have at least 200 dimers/Mb in DNA of skin cells, but those cells would not suffer sufficient damage to induce cell death, as detected by skin peeling. This suggests that repair mechanisms in skin are more competent in lesion removal and subsequent repair than are those observed in cultured skin cells.

We have investigated repair mechanisms in skin in situ in healthy human volunteers. After UV exposure of previously untanned skin sites, biopsies were obtained immediately, after exposure to visible light, or after varying time intervals (in the absence of light). Biopsies were also obtained from unirradiated skin sites. After the epidermis and dermis were separated, the samples were digested in agarose plugs with proteinase $\mathrm{K}$, (and RNase, if appropriate). For analysis of pyrimidine dimers, companion samples were incubated with or without the $M$. luteus UV endonuclease; the DNAs, along with molecular length standards, were electrophoresed on alkaline agarose gels using static field or unidirectional pulsed field electrophoresis; after neutralization, the gels were stained with ethidium, destained, and a digital electronic image obtained with a charge-coupled device camera system (Sutherland et al., Analyt. Biochem. 163:446, 1987). Number average molecular lengths of the DNA distributions are calculated, and the dimer frequencies determined (Freeman et al., Analyt. Biochem.153:119-129, 1986)

In the absence of light, removal of pyrimidine dimers in DNA in human skin is rapid in most volunteers, with about $50 \%$ removal in less than 30 minutes. In some normal individuals, however, the rate of removal is slower, with some 10-15\% removal in 30 minutes. Exposure of UVB-irradiated volunteers to visible light (filtered to remove both UVA and UVB) results in an increase in the rate of dimer disappearance in most but not all subjects.

Since human skin removes lesions from genomic DNA so rapidly, we questioned whether the strategy of more rapid repair of transcribed genes used by human cultured cells would also be used by skin. However, determination of repair of transeribed genes in skin was impeded by two major factors: 1 . the requirement for 10-20 $\mathrm{\mu g}$ of DNA for each determination, whereas less than $1 \mu \mathrm{g}$ of DNA is generally available from a typical biopsy, and 2. the inapplicability of Poisson analysis to DNA in skin in situ, due to its multiple layers of cells and thus varying 
levels of damages in cells in different layers. We developed nanogram-level Southern blotting procedures for quantitative determinations of lesion levels, and determined lesion frequencies by the method of moments, which is applicable to DNA with heterogeneous distributions of damages. DNA was restricted with appropriate enzymes, incubated with or without the UV endonuclease, electrophoresed along with molecular length standards on alkaline agarose gels, transferred to blotting membranes, probed with op random-primed probes, and a radiogram obtained using preflashed film. An image of the optical density on the radiogram was obtained with the CCD camera. DNA distributions were quantitated using electronic imaging, and dimer frequencies determined by the method of moments. We studied the c-myc gene, which is important in cellular housekeeping, and alterations of which are implicated in some neoplasms.

We first ascertained that the c-myc gene is indeed actively transcribed in the dermis and epidermis of human skin. We then determined the rates of repair of total genomic DNA and of the c-myc gene in three healthy volunteers. Rates of repair of genomic DNA and of c-myc were determined using three independent gels (genomic) or blots (c-myc). Genomic excision repair was rapid in all three subjects: one subject removed about $44 \%$ of the dimers in $35 \mathrm{~min}$. The rates of removal of dimers from the c-myc gene were indistinguishable from the rates of genomic repair; the same subject removed about $45 \%$ of the dimers from c-myc in 35 min. These results indicate that in this transcribed gene, no preferential removal of lesions could be detected.

The results of genomic and specific gene repair of DNA lesions in human skin may be contrasted with that in cultured human skin cells, in which excision is rather slow $(-12 \mathrm{hr}$ for removal of 50\% of the lesions), and transcribed genes are repaired more rapidly. Cultured human cells may not express genes necessary for the rapid repair which occurs in skin; even the more rapid repair of transcribed genes in cultured cells is slow by comparison with the rates we observe in the c-myc gene in skin. It is important to examine other transcribed genes in skin to determine the generality of these differences between human fibroblasts in culture and human skin in situ.

- Research supported by NIH grants (CA 23096 to BMS, AR 35296 to RWG and GM 40936 to JCS), by grants from the Wellman Foundation and from Sylvania to RWG, and by the Office of Health and Energy Research of the US Department of Energy. 
THE INDUCTION AND REPAIR OF SOIAR UV-INDOCED DNA DAMAGES; Barry 8. Rosenstein, Department of Radiation Oncology, Box 1236, yount sinal school of Medicine, One Gustave Ievy Place, New York, NY 10029.

$\because$ The induction and repalr of DNA damages produced by exposure of normal human skin fibroblasts to the simulated sunlight produced by a solar simulator were examined. The photoproducts measured were pyrimidine dimers, E. coll endonuclease III-sensitive sites, 6-4 photoproducts, 6-4 photoproduct (Dewar) isomers, DNA-protein crosslinks and DNA single-strand breake. In addition, cellular survival, excision repair and the inhibition and recovery of DNA synthesis were examined. The results of these experiments erve to form a basis for the quantitation of damages induced by exposure to sunlight.

In a second portion of this work, skin fibroblasts derived from three patients exhibiting the disease systemic lupus erythematosus (SIE) were exposed to simulated sunlight. The repair of DHA damages induced by this treatment was examined and generally found to be similar to the repair exhibited by normal human cells. However, abnormalities in the formation and maintenance of DNAprotein crosslinks and DNA single-strand breake were found in SIE-4 and SIE-5 following simulated sunlight exposure. In contrast, sLE-3 cells exhibited responses imilar to normal calls in reference to DNA strand breakage and DNA-protein crosslinking. These Iindings correlate well with the sensitivity of these sie cell strains to simulated sunlight. 
Perplexing Problems in DNA Repair: How Does a DNA Damage Binding Protein Relate to XP-E? How Does UF Endonuclease IIJAP Endonuclease I Relate to XP.D, Cyclobutane Dimers, and Ribosomes?

$\therefore$ Stuart Linn, Scott Keeney, Robert Fellous, and Joon Kim, Div. of Biochemistry and Molecular Biology, University of California, Berkeley

A DNA-damage specific binding protein first described by Feldberg and Grossman (1) was reported by Chu and Chung (2) to be absent from fibroblasts of xeroderma pigmentosum (XP) group E cells. We investigated the occurrence of this protein in cells cultured from nine additional, unrelated XP.E patients and found that all but one of these strains contained nor$\mathrm{mal}$ levels of the protein. Moreover, the activity in these strains had normal thermal stability, behavior on ion-exchange chromatography, and electrophoretic mobility of protein-DNA complexes (3). Furthermore, these is no obvious correlation between the presence of the protein and reported phenotypes of individual patients or their cells.

The binding protein was extensively purified and appears to be a heterodimer with subunits of $124-$ and $41 \mathrm{kDa}$. Peptide sequences give no matches to those in sequence data bases. The enzyme binds UV-irradiated DNA and enzymatic and antibody reagents indicate that cyclobutane dimers are not recognized whereas 6,4-photoproducts are the major lesion recognized. In a permeabilized cell assay, the binding protein does not correct the XP.E defect and is separable from an activity that does.

A number of years ago our laboratory noted that an AP endonuclease activity, AP endo I, was missing or altered specifically in XP-D cells (4). More recently we have observed that a UV endonuclease, UV endo III, is similarly altered and indeed is inseparable from the AP endonuclease (5).

DNA irradiated with $525 \mathrm{~J} / \mathrm{m}^{2}$ is nicked by the enzyme, but DNA irradiated with 46 $\mathrm{J} / \mathrm{m}^{2}$ does not appear to be nicked. The lightly-irradiated DNA does appear to be nicked, however, when treated with UV endonuclease III, then with T4 UV endonuclease(ser), a mutant enzyme that has pyrimidine dimes glycosylase, but not AP endonuclease activity and hence does not nick irradiated DNA alone. The simplest interpretation of these results is that UV endo III cleaves a phosphodiester bond within a cyclobutane dimer.

The enzyme has been purified to yield a peptide of $M_{1}=32,000$. Sequence analysis of the peptide indicates identity with ribosomal protein S3, and the activity (and peptide) crossreact with antisera directed against the $S 3$ protein obtained from ribosomes. Both the peptide and the activity are strongly bound by concanavalin A, UEA and SBA, but not by WGA. DBA and RCA. This lectin binding pattern indicates a nuclear localization. Enzyme activity is eliminated upon treatment with calf intestinal alkaline phosphatase. Conversely activity is enhanced by treatment with CAMP-dependent protein kinase catalytic subunit. The latter treatment results in phosphorylation of the peptide and an altered mobility on SDS.PAGE. We conclude that the DNA repair activities are associated with ribosomal protein S3 and we are currently carrying out structural comparisons between the peptide isolated as an enzyme, the peptide expressed from a cDNA clone in $E$. coll, and the peptide isolated from ribosomes.

1. Feldberg, R. S. and Groseman, L. (1970) Biochemistry 15, 2402-2408.

2. Chu, G. and Cheng, E. (1988) Science 212, 564-567.

3. Keeney, S. Wein, H., and Linn, S. (1991) Mu. Res., DNA Repair (in prese).

4. Kuhntein, Un, Lee, B. Peahoer, E. E. and Limn, S. (1978) Nuc. Ac. Res. S, 117-125.

5. Kim, J. and Linn, S. (1989) J. Biol. Chem, 261, $2739-2745$. 
The evolutionarily conserved RAD6 protein mediates $N$-end dependent protein degradation. Louise Prakash, Department of Biophysics, University of Rochester School of Medicine, 601 Elmwood Avenue, Rochester, NY 14642-8408 USA.

The RAD6 gene of Saccharomyces cerevisiae encodes a $20 \mathrm{kD}$ ubiquitin conjugating (E2) enzyme that is required for DNA repair, DNA damage-induced mutagenesis, and sporulation. The 172 residue RAD6 protein contains a highly acidic carboxyl terminus in which 20 of the 23 residues are acidic, including an uninterrupted stretch of 13 aspartates (1). RAD6 attaches multiple molecules of ubiquitin to histones $\mathrm{H} 2 \mathrm{~A}$ and $\mathrm{H} 2 \mathrm{~B}$ in vitro, resulting in histone molecules containing as many as seven or more ubiquitin molecules (2). Deletion of the acidic tail of RAD6 results in sporulation deficiency but has no affect on DNA repair or damage induced mutagenesis (3). The ubiquitin conjugating activity of RAD6 is required for all its biological activities since mutation of the Cys88 residue in the active site of the enzyme results in a rad6 null phenotype (4).

The structure and function of RAD6 has been strongly conserved among eukaryotes. A celetion mutation (rhp6 4 ) of the RAD6 homolog in Schizosacccharomyces pombe resembles the rad6 $\Delta$ mutant of $S$. cerevisiae in being highly UV sensitive, UV immutable, and sporulation defective (5). These rhp6 $\Delta$ defects are all complemented by the RAD6 gene of $S$. cercvisiae. Similarly, the RAD6 homolog in Drosophila melanogaster, Dhr6, and the duplicated human homologs HHR6A and HHR6B, show remarkable evolutionary conservation $(6,7)$. The Dhr6 and HHR6 genes complement the DNA repair and mutagenesis defects of the S. cerevisiae rad6 $\Delta$ mutant.

Recently, we have uncovered a novel activity of RAD6 protein, its ability to catalyze protein degradation dependent on the ubiquitin protein ligase enzyme that recognizes $N$-terminal residues in proteins (8). In the presence of ubiquitin-activating enzyme (E1), ubiquitin protein ligase (E3), and the ubiquitin-specific protease from rabbit reticulocytes, RAD6 catalyzes E3dependent ubiquitination of proteins, generating multiply ubiquitinated products that are then degraded efficiently by the proteolytic system. The rad6 Ala88 and rad6 Val88 mutant proteins, lacking ubiquitin conjugating activity, are ineffective in catalyzing protein degradation, indicating the requirement of the RAD6 ubiquitin conjugating activity in this reaction. The acidic carboxylterminal region of RAD6, however, is not required for its interaction with E3. The other ubiquitin conjugating enzymes do not substitute for RAD6 in the E3-dependent protein degradation, indicating a specific interaction between RAD6 and E3. RAD6 resembles the mammalian E214K enzyme in the kinetics of ubiquitin protein conjugate formation and protein degradation.

\section{REFERENCES:}

1) Reynolds, P., S. Weber, and L. Prakash (1985) Proc. Natl. Acad. Sci. USA, 82: 168. 172.

2) Sung, P., S. Prakash, and L. Prakash (1988) Genes Dev., 2: 1476-1485.

3) Morrison, A., E. J. Miller, and L. Prakash (1988) Molec. Cell. Biol., 8: 1179-1185.

4) Sung, P., S. Prakash, and L. Prakash (1990) Proc. Natl. Acad. Sci. USA, 87: 26952699.

5) Reynolds, P., M. H. M. Koken, J. H. J. Hoeijmakers, S. Prakash, and L. Prakash (1990)

EMBO J., 9: 1423-1430.

O Koken, M., P. Reynolds, D. Bootsma, J. Hoeijmakers, S. Prakash, and L. Prakash (1991) Proc. Natl. Acad. Sci. USA, 88: 3832-3836.

7) Koken, M. H. M., P. Reynolds, I. Jaspers-Dekker, L. Prakash, S. Prakash, D. Booksma, and J. H. J. Hoeijmkaers (1991) Proc. Natl. Acad. Sci. USA, 88: 8865-8869.

8) Sung, P., E. Berleth, C. Picicart, S. Prakash, and L. Prakash (1991) EMBO J., 10: $2187-$ 2193. 


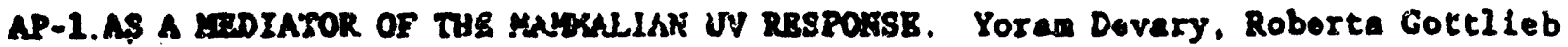
and Michael Karin. Depnrtiret:l of Phermecology, School of Mediclne. University of Cellfornta, San Diego, la Jolla, CA 92093-0636.

Exposure of amodia: cells to DXA-damaging agants leada to activation of a genetlc response kncwi as the Ui response, durting which the expression of a subset of genes is Induced since soveral UV Inducible gonos contein AP-1 binding altos within their promornrs. ve investigated the control of AP-1 activity by DMA-danaging egents. We foind that expreseion of both the c-jun and c-fos protooncogenes, which encude protoins that ford the AP-I complex, is rapidly Induced by two different OHh-iamaing agents, iN and $\mathrm{H}_{2} \mathrm{O}_{2}$. In compardaon to othar letsedlate-early genss, $\varepsilon-j u n$ was by far the most responsive to these ageats, whlle c-fos wer acsi respcralive to the phorbol ester TPA. The

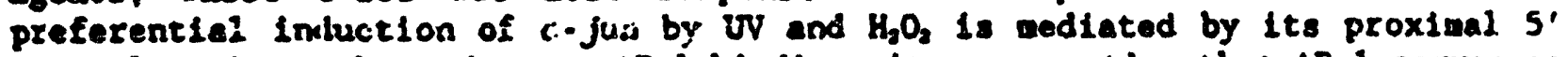
control region and requires an AP-I binding olte, suggesting that AP-1 serves as an early target for the sigruil tranuduction pathway ellcited by DNA damage. Indeed. AP-1 DHA binding eactivity 1 s repldiy Induced by $\mathrm{WV}$ or $\mathrm{H}_{2} \mathrm{O}_{2}$. Independently of de novo prutein synthesie. While down-reguletion of protein kinase $C$ does not provent the Induction of c-jes by ov, egents that act as free radical scavengera aro effective Inhibltors of AP-1 ectivity. UV and $\mathrm{H}_{2} \mathrm{O}_{2}$ also Induce NFKB DNA blading activity. This inflict:on was also blocked by free radical scavengers. In other experdeents, wo failed to induce AP-1 activity by transfecting cells vith UV-damaged DMA. Therefora ws consldered tho posalbility that the laitial algnal triggering the iv resporizz can bo provlded by another by-product of UV 1rradiation. In 11 ght of the affoct of free radical scavengers, that al gnal may be provided by free radicals. Indsed, wo found that treatment of hela celle with

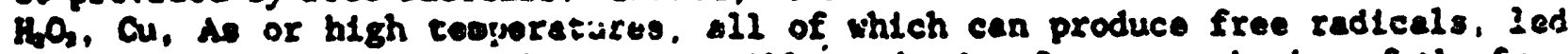
to induction of AP-1 ectivity. A poesiblo sechanisu for trananiesion of the free radical al gnal to AP-1 linvolves a phosphoryletion cascede. Preliminary results Indicate tha': uv lrradiation itaulates cJun phosphorylation, a codification known to Increase the activity of the protein and laad to induction of c-Jun transcripedon by a positive aur.eregulatory wechanlea.

\section{References:}

1. Devary, Y., Gotelisb, R. and Karin, H. (1991) Mol. Cell. B101. 11:2804. 2821.

2. Bisotruy, B., Smenl, I. and Karln, Y. (1991) Mature 351:122-127.

3. Smal, T., Binetruy, B., Kercola, D., Birrer, M. and Karin, M. (1991) Mature In Prese.

Supported by the Doparteont of Energy. 
Polx(ADP-ribore): A unlaue resoense in eucarvoile sells to DNA damno

Guy G. Polrler, Poly(ADP-ribose) Metabolism Group, Molecular Endocrinology,

- CHUL, 2705 Lautier BIvd, Québec, Canada, G1V 4 G2.

$\therefore$ Poly(ADP-ribose) synthesis is greally increased in response to DNA damage (1). The enzyme which synthesized this polymer is poly(ADP-ribose)polymerase (PARP) and the hydrolytic enzyme is the glycohydrolast. The PARP demonstrates great affinity for double and single strand breaks through its two zinc fingers (1). We have shown that PARP can decondense the nucleoscme structure and that is a reversible phenomenom (2). Funthermore the action of these enzymes simultaneously could lead to a decondensation of the chromatin structure leading to the labelling of core histones preferentially. Thus this system could affect key repair events such as nucleosome rearrangement.

This enzyme complex (the polymerase and the glycohydrolase) could affect DNA repair by binding to DNA internptlons and inhibit proper DNA repair until the polymerase is automoditied. We have also evidence that the PARP is modified in the threo different domains such as DNA binding, automodification and NAD binding domains (3). We have reconstituted a poly(ADP-ribose) turnover system in which the polymerase and the glycohydrolase are active at the same time $(4,5)$. The properties of this system will be described and its use in vitro DNA repair systems will be discussed. The synthesis of this polymer could have many effects on DNA repair: firstly the enzyme automodification could prevent this enzyme from binding to DNA strand breaks; secondly through post synthetic modification of other nuclear proteins or enzymes it could modulate chromatin structure and finally through electrostatic Interaction it could affect histons DNA binding or interact with DNA repair/replication enzymes. In conciusion, the poly(ADP-ribose) metabolism could be a sophisticated system that most oucaryotic organisms use as a mean to control the highly complex DNA repair and replication system. 
This research is supported by MRC, SRC and NSERC.

(1) de Murcia, G. Huletsky, A. and Poirier, G.G. (1988) Modulation of chromatin structure by poly(ADP-ribosyl)ation. Blochem. Cell Biol. 66: 626-635.

. (2) Hulersky, A., de Murcia, G., Muller, S., Hengartner. M., Monard, L. Lamarre, D. and Poirier, G.G. (1989) The effet of poly(ADP-ribosyl)ation on native and H1. depleted chromatin. A role of poly(ADP-ribosyl)ation on core nucleosome structure. J. Biol. Chem. 264: 8878-8886.

(3) Desmarais, Y., Ménard, L., Lagueux, J. and Poirier G.G. (1991) Characterization of automodification sites and NADase activity. Biochim. Biophys. Acta, 1078: 179186

(4) Mónard. L., Thibault, L. and Poirier, G.G. (1990) Reconstitution of an in vitro poly(ADP.ribose) turnover system. Biochim. Biophys. Acta 1049: 45-58.

(5) Thomassin, H., Jecobson, M.K., Guay, J. Verreault, A., Aboul-Ela, N., Ménard, L. and Poirier, G.G. (1990) An attinity matrix for the purification of poly(ADP-ribose) glycohydrolase. Nucleic Acids Res. 18: $4691-4694$. 
Protein splicing in the maturation of the recA gene product of Mycobacterium tuberculosis. Steven G. Sedewick ${ }^{1}$, Elaine O. Davis ${ }^{2}$ and M. Joseph Colston ${ }^{2}$. Laboratory of Yeast Genetics and Laboratory of Leprosy and Mycobacterial Research², National Institute for Medical Research, - Mill Hill, London NW7 1AA, Great Britain.

The recA locus of $M$. mberculosis was cloned and expressed in $E$. coli. Although the gene has an open reading frame for an $85 \mathrm{kDa}$ polypeptide, it in fact yields a RecA product of 40 $k D a$. This product was confirmed as a RecA protein by the partial complementation of $E$. coli recA mutants for defects in recombination, repair, induced mutagenesis and SOS induced gene expression. Furthermore the $M$. uberculasis RecA protein was cross reactive with polyclonal antibodies to $E$ coli $R e c A$ and has large degrees of amino acid sequence conservation when compared with other species. Thus the ultimate product of the $M$. tuberculosis recA locus has strong functional, immunological and structural similarities with the RecA protein of $E$. coli, even though it is produced from a gene more than twice as long as in other species. This work points to a mechanism of protein rather than RNA splicing to produce a RecA protein of conventional size from an elongated and atypical recA gene.

The cloned $M$. muberculosis recA DNA specified a $2.8 \mathrm{~kb}$ message corresponding to the whole potential open reading frame of $85 \mathrm{kDa}$. However maxicell analysis showed that two protein products of 40 and $45 \mathrm{kDa}$ were made. From the properties of deletion and frameshift mutants it appears that a full length mRNA is made and translated into an $85 \mathrm{kDa}$ precursor protein. A protein splicing reaction then occurs to remove a central $45 \mathrm{kDa}$ "spacer" protein fragment and at the same time joining amino- and carboxy-terminal portions to form the mature RecA protein.

The abolition of splicing in deletion mutants has defined several portions of the spacer protein sequence needed for processing. In contrast, RecA protein motifs do not seem to be essential since the spacer protein can also be spliced out of the Lace fragment of $\beta$ galactosidase when expressed from a plasmid with the central section of the $M$. tuberculosis recA locus subcloned into lacZ. There are amino acid sequence similarities of the spacer molecule with the budding yeast vacuolar ATPase encoded by the VMA1/TFP1 gene. Significantly this protein also undergoes splicing and the sequence homologies are at the putative splice junctions of both molecules. Current work examines the role of these junction motifs and questions if aplicing is autocatalytic or if it uses additional activities of the host organism. 


\section{CEULULAR RESPONSES TO ENVIRONMENTAL DNA DAMAGE}

Intertwining of Regulation and Function in Mutagenesis. Melissa Lee, Dominique Bumouf, Sumati Murli, Caroline E. Donnelly, and Graham C. Walker. Department of Biology, Massachusetts Institute of Technology, Cambridge MA 02139.

In Escherichia coli, mutagenesis by uftraviolet light and various chemicals has been shown not to be a passive process but rather to require the participation of specific cellular functions. Genetic analyses have revealed that the products of three genes - umUD, umuC, and recA - are required for the specialized processing of damaged DNA that converts it to mutated DNA. Null mutations in any of these bci make $E$. coli nonmutable by UV and many chemicals. The umUD and UmuC genes are organized in an operon that is repressed by the LexA protein and is regulated as part of the recA+lexA+-dependent SOS response. In response to DNA damage, the RecA protein becomes activated by binding to an intracellular inducing signal, probably single-stranded DNA. Once activated, RecA mediates the cleavage of the LexA repressor and various bacteriophage repressors by facilitating an othenwise latent capacity of these molecules to autodigest. The cleavage of LexA leads to increased expression of the UmuD and UmuC genes. We have shown that the UmuD protein shares homology with the carboxyl terminal domains of LexA (and several bacteriophage repressors) and undergoes a RecA-mediated cleavage at its Cys24Gly25 bond that activates it for its role in mutagenesis. The carboxyl-terminal fragment, UmuD', is necessary and sufficient for the role of UmuD in mutagenesis. Thus the regulation of umuD involves transcriptional derepression and posttranslational activation events that are mechanistically related. Furthermore, genetic evidence suggests that recA plays a third role in mutagenesis apart from its role in mediating the cleavage of LeXA and UmUD. A set of missense mutants of umuD was isolated and was shown to encode mutant UmUD proteins that are deficient in RecA-mediated cleavage in vivo but which can be partially cleaved at a higher UV dose. Most of these mutations are dominant to UmuD+ yet do not interfere with SOS induction. Although both UmuD and UmuD' form homodimers, we have obtained evidence that they preferentially form heterodimers. On the basis of these observations we have suggested that the intact UmuD protein plays a role in modulating the ability of the UmuD' protein to participate in the specialized processing of damaged DNA that gives rise to mutations. In addition, we have observed that the efficiency of umuDC-dependent UV mutagenesis is greatly reduced by mutations affecting the groES and groEl heat-shock genes. These genes encode proteins that function as molecular chaperones which mediate protein folding and protein-protein interactions. It seems possible that they play a role in the proper assembly of a complex containing umuDC gene products that is required for SOS mutagenesis. In an effort to learn more about the nature of the interactions of UmuD and UmuD' with other proteins in this complex process we have initiated an approach based on the construction of a ceries of monocysteine derivatives of UmUD. The UmuD protein contains only a single cysteine, Cys24, and this can be changed to an alanine without any detectable effect on the biological function of the protein. This observation has allowed us to generate series of monocysteine derivatives of UmuD, each of which carries a single cysteine at some particular site on the protein. By measuring the ability of the various derivatives to react with thiol-specific reagents and by using crosslinking agents that can react with thiol groups we are gaining insights into which parts of UmuD are involved in interactions with other proteins under different conditions. 


\title{
ABASIC SITES AND 8-0XOPURINES
}

\author{
Arthur P. Grollman
}

Endogenous DNA damage is reflected by the presence of abasic sites and 8-oxopurines. Both lesions can be created by the attack by oxygen free radical species or by spontaneous $\therefore$ or enzymatic depurination. 8-Oxopurines and abasic sites are implicated in spontaneous mutagenesis, carcinogenesis, and the aging process.

The structure of duplex oligodeoxynucleotides containing 8-axodeoxyguanosine (8-oxodG) and abasic sites have been established by 2D-NMR spectroscopy. 8-OxodG assumes the syn or anti conformation, depending on the base to which it is paired (1). Loss of a single base will not affect helical structure if a purine is located opposite the lesion (2). When used as a template for DNA synthesis in vitro, oligodeoxynucleotides bearing 8-oxodG promote incorporation of DCMP and DAMP opposite the lesion; the ratio of nucleotides incorporated depends on the DNA polymerase involved (3).

Plasmids containing site-specific modifications were used to establish the mutagenic specificity of abasic sites and 8-oxopurines in DNA (4). Chemically-modified oligodeoxynucleotides were introduced into shuttle plasmid vectors then used to transform bacteria or transfect mammalian (COS) cells (4). Following replication, plasmid DNA was recovered and the position and nature of the mutation(s) determined by oligodeoxynucleotide bybridization and DNA sequence analysis. Using this general approach, the mutagenic specificity (G.C-T.A) of 8-oxodG in prokaryotic and eukaryotic systems has been established $(5,6)$.

The mutagenic properties of 8-oxodG suggested that constitutive enzyme(s) might effect its repair in genomic DNA. A DNA glycosylase, recognized earlier for its capacity to excise formamidopyrimidines from DNA, proved effective in removing 8-axodG $\left(K_{M}=8 n M\right)(7)$. Oligodeoxynucleotides in which dC, dT or dG are paired with 8-oxodG were cleaved $3^{\prime}$ and $5^{\circ}$ io the lesion while duplexes containing 8-oxodG:dA or mispairs involving dG or 8-oxodA are relatively unaffected. The $\left(3^{\circ} \rightarrow 5^{\circ}\right)$ editing function of DNA polymerase is unable to excise dA from 8-oxodG:dA formed during DNA replication. This mutagenic intermediate is readily extended by DNA polymerase (3), generating transversion mutations in vitro and in vivo.

Genetic analysis independently establishes the mutagenic potential of 8-oxodG. The mutM gene codes for 8-axodG-glycosylase. G.C $\rightarrow$ T.A mutations observed in mut $M$ strains of $E$. coli (8) are predicted by the experiments described above.

The mutagenic potential of abasic sites has been investigated. A synthetic procedure was developed by which alkali-stable abasic sites can be introduced at any desired position in DNA (8). A modified tetrahydrofuran moiety, isosteric with 2-deoxyribofuranose, serves as a structural analog of the natural AP site. Synthetic oligodeoxynucleotides containing this analog are readily cleaved by Class II endonucleases and serve as templates for DNA 
polymerase reactions in vitro. DAMP is most frequently incorporated opposite synthetic abasic. sites. Significant readthrough is observed when DNA polymerases lacking $3^{\circ} \rightarrow 5^{\prime}$ exonuclease are used for primed template extension reactions (8).

Paired abasic sites were introduced at defined positions in the $T c^{\mathbb{R}}$ gene of a shuttle plasmid vector; base mismatches are used to distinguish the DNA strands. Parallel experiments were conducted in bacteria and mammalian (COS) cells. Targeted mutations, including single base deletions, predominate with AAMP being incorporated opposite the lesion. We conclude from these studies that synthetic abasic sites are mutagenic and that translesional synthesis occurs in vivo.

1. Kouchakdjian, M., Bodepudi, V., Shibutani, S, Eisenberg, M., Johnson, F, Grollman, A.P. and Patel; D.J. Biochemistry, 30, 1403-1412 (1991).

2. Kalnick, M., Chang, C.-N., Grollman, A.P. and Paitel, D.J. Biochemistry 27, $924-931$ (1988).

3. Shibutani, S., Takeshita, M., and Grollman, A.P. Nature 349, 431-434 (1991).

4. Moriya, M., Takeshita, M. Johnson, F, Peden, K, Will, S., and Grollman, A.P. Proc. Nath Acad. Sci, 85, 1586-1589 (1988).

5. Moriya, M., Ou, C, Bodepudi, V., Johnson, F, Takeshita, M., and Grollman, A.P. Mutation Res. 254, 281-288 (1991).

6. Wood, M.L., Dizdaroglu, M., Gajewski, E. and Essigmann, J.M. Biochemistry 29, 70247032 (1990); Moriya, M., Ou, C. Bodepudi, V, Johnson, F, Takeshita, M, and Grollman, A.P. Mutation Res. 254, 281-288 (1991).

7. Tchou, J, Kaspi, H., Shibutani, S, Chung, M.H., Laval, J., Grollman, A.P. and Nishimura, S. Proc Nath Acad. Sci. 88, 4690-4694 (1991).

8. Cabrera, M., Nghiem, Y, and Miller, J.H. J. Bacteriol 170, $5405-5407$ (1988); Michaels, M.I., Pham, L, Cruz, C. and Miller, J.H. Nuch Acid Res. 19, 3629-3632 (1991).

9. Takeshita, M., Chang, C.-N., Johnson, F, Will, S.G. and Grollman, A.P. J. Biol. Chem. 262, 10171-10179 (1987). 


\section{"Cellular Responses to Environmental DNA Repair"}

Mechanisms of Carcinogen-Induced Mutagenesis in Diploid Human Cel1s: Role of DNA Repair. Yeronica M. Maher, Ruey-Hwa Chen, Lubov Lukash, and J. Just in McCormick, Carcinogenesis Laboratory, Michigan State University, East Lansing, MI 48824

We have studied the effects of nucleotide excision repair (NER) and of $0^{6}$. alkylguanine-DNA alkyltransferase (AGT) on the kinds and location (spectrum) of mutations induced in the hypoxanthine (guanine) phosphoribosyltransferase (HPRT) gene of diploid human cells by various carcinogens. For the studies of the effect of NER on mutations induced by UV or $( \pm)-78,8 \alpha-$ dihydroxy-9a,10a-epoxy$7,8,9,10$-tetra-hydrobenzo[a]-pyrene (BPDE), we synchronized repair-proficient or repair-deficient (XP) cells and treated them at various times in the cell cycle to give them various lengths of time for repair before the onset of $S$ phase. For the studies of the effect of AGT on mutations induced by MNNG, we exposed cells with normal NER and AGT capacity in the presence or absence of $O^{6}$-benzylguanine $\left(0^{6}-B z G\right)$, which completely inhibits AGT activity. To determine the effect of NER and $A G T$ repair on ENU-induced mutations, we compared normal and XP cells in the presence or absence of $O^{\circ}-B 2 G$.

Analys is of the spectrum of mutations induced by BPDE showed that if normal human cells are allowed time for repair before $S$ phase, the premutagenic lesions formed (guanine adducts) are removed from the transcribed strand of the gene faster than from the nontranscribed strand. No change in strand distribution was seen with XP cells. These results suggest that strand-specific repair of BPDE adducts occurs in human cells. To test this hypothesis, we used UvrABC exinuclease in conjunction with Southern hybridization and strand-specific probes to measure the initial number of BPDE adducts formed in each strand of the HPRT gene and their rate of repair. We also investigated the possibility of preferential repair of such damage from actively transcribed genes by comparing these rates with the rate of loss of BPDE adducts from the inactive 754 locus located in the same chromosome, the $X$ chromosome. Following exposure to 1.0 or $1.2 \mu \mathrm{BPDE}$, the frequency of adducts formed in either strand of a $20 \mathrm{~kb}$ fragment that lies entirely within the transcription unit of the HPRT gene was similar. The frequency of adducts formed in the $14 \mathrm{~kb} 754$ fragment was $-20 \%$ lower than in the HPRT gene. The rate of repair in the two strands of the HPRT fragment differed significantiy. Within $7 \mathrm{hr}$ after treatment with $1.2 \mu \mathrm{M}$ BPDE, 55\% of the adducts had been removed from the transcribed strand, but only $26 \%$ from the other strand; after $20 \mathrm{hr}$ of repair, these values were $87 \%$ and $58 \%$, respectively, confirming the prediction of our mutagenesis studies. In contrast to the rapid rate of repair in the HPRT gene, only $-14 \%$ of the BPDE adducts were lost from the 754 locus in $20 \mathrm{hr}$, a value even lower than $38 \%$ lost from the overall genome. The results demonstrate strand-specific and preferential repair of BPDE adducts in human cells. The heterogeneous repair of BPDE adducts cannot be accounted for merely by the increased rate of repair of the transcribed strand of active genes, suggesting a role for chromatin structure.

MNNG and ENU react with 12 nucleophilic sites in DNA to induce a variety of lestons, but $0^{6}$-alkylguanine and $0^{4}$-alkyithymine are considered to be the most effective premutagenic lesions produced, mispairing with thymine and guanine, respectively. $0^{6}$-alkylguanine is repaired by AGT. To examine the effect of AGT repair on the spectrum of mutations induced by MNNG, we pretreated AGT-proficient human cells with $0^{6}-B Z G$ for $2 \mathrm{hr}$. The AGT activity was reduced to $\leq 1.6 \%$ of the control. Populations of cells pretreated with $0^{6}-B 2 G$ for $2 \mathrm{hr}$, or not pretreated, were exposed to various doses of MNNG and assayed for survival and mutant frequency. $0^{6}-B Z G$ was added for an additional $24 \mathrm{hr}$ to the appropriate 
dishes. The results showed that elimination of AGT activity increased the frequency of MNNG-induced mutants 12- to 20-fold over that seen in AGT proficient cells. DNA sequence analysis of the coding region of the HPRT gene in mutants from the two populations showed that $96 \%$ of the base substitutions (48/50) were $G \cdot C \rightarrow A \cdot T$, and that even though AGT repair lowered the frequency of mutants by $390 \%$, it did not affect the kinds of mutations nor the strand distribution of the premutagenic lesions. Several "hot spots" were seen, and there was evidence of non-random repair, 1.e. AGT repaired more lestons from the GoC-rich (5') half of the gene than from the 3 ' half. We carried out similar studies with ENU in NER/AGT-profictent normal cells and in NER-deficient, AGT-profictent XP cells. Sequence analysis of mutants derived from cells that had been pretreated with $0^{B}-B 2 G$, or not pretreated, and then exposed to ENU showed that the frequency of mutants is highest in cell's lacking both NER and AGT repair, and the proportion of base substitutions involving $G$ or $T$ bases approximates the distribution of $0^{6}$ EtG and $0^{2}$-EtT and $0^{4}$-EtT. The data from the four sets of cells (120 base substitutions) indicate that AGT repairs only ethylated guanine bases. The data also suggest that NER excises both ethylated guanine bases and ethylated thymine bases. (This research was supported by DHHS Grant CA21253 from the National Cancer Institute.) 
AACR Special Conference on Cancer Research

"Cellular Responses to Bovironmental DNA Damage"

Banff, Alberth, Cunda December 1-6, 1991

RIchard J. Albertinl, The University of Vermont, Burlington, VT ABSTRACT

\section{THE EMERGINO PICTURE OF SOMATIC MUTATIONS IN HUMANS}

Somatic mutations arising in vivo in humans can be measured and analyzed for four recorder genes, i.e. the hemoglobin (Hb) and glycophorin A (spa) genes, studied in red blood cells, and the hypoxanthine-guanine phosphoribosyltransferse (hprt) and major histocompatibility (HIA) genes, studied in T-lymphocytes. The specific mutational events measured by these recorder genes may differ, however, because of effective target size, chromosomal location, cell of origin or method of selection. These factors must all be considered when interpreting in vivo mutagenicity assays.

Background mutant ("variant" when mutational basis cannot be established) frequencies in non-mutagen exposed individuals measure "spontaneous" mutations. Although their genesis is unbown, background mutations provide the context for interpreting quantitative mutagenicity results in exposed populations. Mean mutant (variant) frequencies for normal young adults are approximately: Hb $(4 \times 109)<$ hpr $(5-10 \times 109)<g p a(20 \times 109)<$ HILA $(30 \times 10 \%$. Mutagen exposed individuals show decided elevations. Results following radiation and chemical exposures will be presented.

Molecular mutational spectra are being defined for mutations in lymphocytes, where DNA is available for analysis. At present, the hprt system provides the largest data base. In adults, approximately $15 \%$ of the background mutations in this gene result from gross structural alterations (deletions, insertions, corplex changes), the remainder from "point-mutations," i.e. base substitutions (transitions, transversions), splice site changes, frameshifts, and small deletions/insertions. All changes, including large deletion breakpoints, appear to be randomly distributed. In contrast, "spontaneous" hprt mutations in the fetus, as reflected in placental blood lymphocytes, show characteristic deletions of exons 2-3. "Point mutations" are the minority class in the fetus.

For HLA, complete deletions account for approximately $30 \%$ of the mutations. Recent molecular analyses show that approximately $30 \%$ also result from mitotic recombination.

It is important to define the maximum size deletion that can be detected in a mutation ascay. Some "deletions" of HIA show an associated phenotypic loss of the "cis" allele at a closely linked HIA locus. Unless due to somatic recombination, this indicates a deletion of approximately $1 \mathrm{Mb}$. Hpr mutations can also result from deletions of this size, as revealed by Southern blot studies of co-deletions of linked markers and analysis by pulsed-field gel electrophoresis. 
Mutations resulting from exposures to enviroamental mutagens are being studied to determine if "induced" mutational spectre differ from "epontuneous." For hpm, lonixing radiutions result in dose-selated inereases in linge deletions, also with spperently nodom -breaipoints. Posable hpr point-mutational epectur for defining rediation and chemical exposures are being sought.

Responsiveneas to envirionmental mutagens/carcinogens (all recorder zenes) and ability to detect somatic recombination (HIIA and gpa) indicate that in vivo recorder gene mutations may serve as surrogates for cancer mutations. To these may be added two findings with the $h p n$ system. First is the demonstration that mutations of this gene arise preferentially in dividing T-cells, which then undergo clonal expansions in vivo and accumulate additional mutations in the sume clone, reminiscent of the "multiplo-hits" required in the evolution of cancer. Second is the observation that spontaneous fetal hpre mutations have characteristic intragenic deletions. The breakpoint sites for these deletions contain all or part of the conseasus heptamer requence [CAC(T/A)GTG], which is the recognition sequence for the V(D)J recombinase that mediates cleavage of the T-cell receptor gene (or immunoglobulin gene in B-lymphocytes) during cellular maturation. Therefore, an illegitimate V(D)J .ecombinase mediated deletion occurs as a spontaneous mutational event in hpr. This is a newly recognized bind of mutation, i.e. a "differentiation mutation." Illegitimate V(D)J recombinase deletions/rearrangements are known to occur in a variety of lymphoid malignancies, including $25 \%$ of acute T-cell leukemias, where mutation in a growth factor gene may be of pathogenic importance. 
Title of Conference: "Cellular Responses to Environmental DNA Damage"

DUAL ROLE OF DRUG-METABOLIzING ENZYMES IN CANCER? Daniel W Nebert, Dartiel D. Petersen, and Alvaro Puga. Department of Environmental Heal th, University of Cincinnati Medical Center, Cincinnati, Ohio 45267-0056 U.S.A.

Numerous studies have shown that individuals who had smoked cigarettes for decades, who then finvlly stopped smoking for severd years, exhibit less risk of developing bronchogenic carcinoma than individuals who continue to smoke. Why is the increased risk of lung cancer associated with the continuntion of smoking? Such epidemiological studies strongly suggest that tumor promotion is an important factor. The properties of "drug-metabolizing enzymes" (DMEs) have been studied extensively in the metrbolic potentiation of procarcinogens--leading to DNA adduct formation, mutation fixation, and activation of oncogenes (tumor initiation). It is proposed here that DMEs might play an even more important role in receptor-mediated siganl transduction pathways involved in tisue-specific growth and proliferation (tumor promotion).

DMIEs have classically been defined as those responsible for the detoxification and excretion of foreign chemicals. DMEs are divided into "Phase I" and "Phase II" reactions. Phase I enzymes introduce a functional group such as OH into the substrate; Phase II enzymes then use this group as a "handle" for conjugation with such mojeties as glucuronic acid, sulfate, or glutathione, yielding a bydrophilic product. P450s comprise most of the Phase I enzymes. Based on their evolutionnry relatedness, P450 genes are named with the root "CYP," denoting cytochrome 2450. Gene families are designated by numbers; subfamilies are represented by letters, followed by a number for the individual gene. More than 190 genes in eukaryotes and prokaryotes have been cloned thus far, and current estimates of the total aumber of functional P450 genes in any given mammalian species range between 60 and more than 200. Each functional gene appears to encode a unique enzyme. There has been a great deal of attention given to the role of $\mathbf{P 4 5 0}$ enzymes in tumor initiation.

In terms of tumor promotion, virtually every ligand known to bind to a receptor in the nuclear hormone receptor superfamily is associated with increases in particular subsets of P450 and other DMEs. These enzymes, in turn, participate in the metabolism (synthesis as well as degradation) of the ligand effectors. This ligand-modulated transcription of genes hes been demonstrated to up- or down-regulate numerous signal transduction pathways involving growth, morphogenesis, homeostasis, proliferntion, and neuroendocrine functions.

The clinical $A H$ polymorphism (aromatic hydrocarbon responsiveness) is an exciting example in the context of how genetic might influence both tumor initiation and promotion. The human polymorphism has been uncovered largely due to corresponding genetic differences first chancterized in the mouse. The murine $A h$ locus has been defined as the gene encoding the aromatic hydrocarbonbinding (Ah) receptor, responsible for the inducibility of two P450 genes plus several Phase II genes. The human CYPIAI (cytochrome $\left.P_{1} 450\right)$ and CYPIA2 ( $\left.P_{3} 450\right)$ genes encode enzymes that transform procarcinogens such as polycyclic hydrocerbons and arylamines, respectively, to toxic and carcinogenic metabolites. The high-affinity A heceptor and, hence, greater levels of inducible CYPIAI and CYP1 A2, can result in larger concentrations of reactive intermediates important for tumor initiation.

On the other hand, the Ab receptor has been shown in animal studies to play a role in growth and differentiation signal transduction pathways: tissuo- or cell type-specific teratogenesis, programmed cell death of immature thymocytes, and epithelial hyperplasia. As a tumor promoter and acting via the Ah receptor, dioxin is known to be far more potent then the classical tumor promoter, phorbol exter. The pretranscriptional Ah receptortigand-containing complex is likely to be heteromeric. The cytosolic receptor appears to associnte with HSP90, the Ab receptor nuclear translocater (ARNI) gene has recently been isolated, but the DNA-biading subunit and possibly other moieties remain to be cloned. About one-tenth of Caucasians are known to exhibit high CYP IAI inducibility, and at least four atudies have reported that the high inducibility phenotype has greater risk than the low phenotype for bronchogenic carcinoma; another study has shown a correlation between the high inducibility phenotype and cancer of the larynx and ord cavity. It is proposed that allelic $A H$ differences might affect not only genotoxic, but also nongenotoxic, mechanisms of certain types of eancer. 
TOXICTTY, MUTAGENICITY, AND MUTATIONAL SPECTRA

OF N-ETHYLN-NITROSOUREA IN HUMAN CELL LINES

WITH DIFFERENT DNA REPAR PHENOTYPES

\author{
Thomas R. Skopek \\ Department of Pathology \\ University of North Carolina at Chapel Hill \\ Chapel Hill, NC 27599
}

We have examined the toxicity, mutagenicity, and mutational spectra of N-ethyl-Nnitrosourea (ENU) in three Epstein-Barr virus transformed human lymphoblastoid cell lines, each with a different DNA repair phenotype. One cell line lacks $0^{6}$-alkylguanine-DNA alkyltransferase (AOT) activity; another, derived from a patient with xeroderma pigmentosum (complementation group A) lacks nucleotide excision repair (NER) capability, and the thind is competent in both repair functions. Further modulation of DNA repair phenotype was achieved with the use of $0^{6}$-benzylguanine, a specific inhibitor of $0^{6}$ alkylguanine-DNA alkyltransferase, so that the repair of DNA ethyl adducts could be studied in cell populations with every combination of the two repair phenotypes.

Cells were exposed to ENU both in the presence and absence of $0^{6}$-benzylguanine and population survival, growth, and mutagenesis at the hprt locus were measured. Results for all three measurements indicated that the lack of either AGT or nucleotide excision repair significantly impairs the ability of human cells to repair ethylated genomic DNA. ENU-induced mutagenicity was increased to a similar degree (2-3 fold) relative to the repair-competent cells in both AGT-deficient and NER-deficient cells at all ENU concentrations tested (0.1 - 1.0 mM). Furthermore, the inhibition of AGT in XP cells with benzylguanine did not increase toxicity or mutagenicity, suggesting that AGT and NER cooperate in the removal of toxic and mutagenic DNA ethyl adducts.

Mutational spectra was determined in all three cell lines following exposure to $0.1 \mathrm{mM}$ ENU (no benzylguanime). At lesst 26 clones resistant to 6-thioguanine from each cell line were sequenced. Of the characterized mutations, $89 \%$ were single-base pair substitutions. Transitions and transversions were found at AT and GC base pairs in all three cell lines. The largest difference within the spectra was in the rate of transitions at $G C$ base pairs. Cormpared to the repair-competent cell line, this mutation type was elevated about 8-fold in the AGT-deficient cells and about 3-fold in the NER-deficient cells.

The formation and persistence of $O^{6}$-ethylguanine, $O^{4}$-ethylthymine, and $O^{2}$-ethylthymine were also quantitated in the genomic DNA of the three cell lines in the presence and absence of benzylguanine. Repair of the O-ethylated thymines was slow and not related to either DNA 
repair phenotype. $0^{6}$-ethylguanine was repaired with a half-life of about 8 bours in cells which expresised both AGT and NER functions. Cell expressing AGT but lacking NER showed only slow repair of $0^{6}$-ethylguanine ( $43 \mathrm{hr}$ half-life), while cells lacking AGT showed no measurable repair of $0^{6}$-ethylguanine regardless of nucleotide excision repair activity. These resulis again

. suggest that AOT and NER cooperate in the repair of $0^{6}$-ethylguanine in buman cells.

Quantitative comparisons 5 DNA adduct levels with the frequency of specific types of ENU. induced mutations suggest that $0^{6}$-ethylguanine, $0^{4}$-ethylthymine, and $0^{2}$-ethylthymine in the DNA of replicating human cells are highly efficient promutagenic adducts. 
VARIATION IN CYTOGENETIC RESPONSE OF LYMPHOCYTES

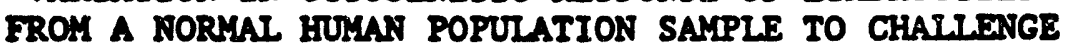
WITH VARIOUS MUTAGENS ${ }^{2}$

\author{
M.A Bender and R.B. Setlow \\ Medical and Blology Departments \\ Brookhaven National Laboratory \\ Upton, New York 11973 \\ USA
}

We are anking a study of various responses of lymphocytes from members of a population of normal, healthy people (BNL employees) to four different mutagens. Our objective is to test the Idea that there may be persons in the apparently normal population who exhibit abnormally high (or low) responses, possibly for genetic reasons, and who may thus be at somewhat elevated (or reduced) cancer risk, and that enzymatic repair deficiencies are involved. The mutagens, $x$-rays, ov light, $N$-methyl-N-nitro-nitrosoguanidine and uitomycin C, were selected to 'exercise' different enzymatic DNA repair pathways for which there are known, extreme genetic deficiencies (1.e., AT, XP and FA) or a suspected one (1.e., the mer" phenotype). The endpoints, respectively, are, micronucleus induction (BN), unscheduled DNA synthesis (UDS), sister chromatid exchange Induction (SCE), and SCE. In addition, we have been neasuring directly one of the enzymes thought to be involved $\left(0^{6}\right.$-methylguanine transferase $\left.\left(0^{6}-\mathrm{MTT}\right)\right)$, and are in the process of adding measurement of other related repair measures (1.e., DSB repair for $x-r a y s$ and cyclobutane diner excision for UV).

To date, we have sampled 151 persoins, 53 of them twice, 17 three sines, 6 four times and 2 five times (or $229^{\prime}$ person-samples'). The repeats are done to assess the degree of sample-to-sample variation, as opposed to person-toperson variation, as well as to check temporal trends. Our hope of detecting variants depends on the distribution of responses both among cells and anong persons, and these distributions are being studied. Known confounding factors, like sex and cigarette smoking for spontaneous SCE, as well as possible ones like age are being studied. Other information, like personal and family health and employment history is collected. The long-standing BNL retirement and aedical benefit plans allow us to hope that eventually significant morbidity and mortailty data can be collected for our study population to prospectively test our hypothesis.

Spontaneous and $x$-ray-Induced aN data have been collected two ways, with and without cytocalasin-B. In the latter case, information was collected on cell proliferation kinetics to allow correction of the raw data for losses fron extra cell divisions. There is no statistically-significant difference between the corrected non-cytocalasin-B data and that from the new nethod (aeans $1.0 \pm 0.5$ and $1.1 \pm 0.9$, respectively for controls, and $16.2 \pm 6.3$ and $16.4 \pm 7.4$, respectively for the irradiated $\left(G_{0} ; 3 \mathrm{~Gy}\right.$ ) cells. The mean for unirradiated samples by either sethod is $1.0 \pm 0.6 \mathrm{kN}$ per 100 cells (range 0.1 - 2.9), while that for Irradiated cells is $16.2 \pm 6.3$ (range 6 - 43). The control and Irradiated distributions of IN among cells both look like the expected overdispersed Poisson distributions. For both control and irradiated ceils, the distributions of means anong subjects appear distinctly binodal. 
Interestingly, two cases appear in the upper $5 \%$ of subjects for both control and irradiated samples.

WDS data have been collected for untreated and for $G_{0}$-treated 1ymphocytes. The untreated mean is $1.0 \pm 0.9$ grains per nucleus (range 0 . 4.9). For Go (unstimulated) cells exposed to $15 \mathrm{~J}$ per $\mathrm{m}^{2}$ of $254 \mathrm{~mm}$ UV, the mean $1812.0^{\circ} \pm 5.2$ (range 5 - 34). The distribution of individual means is, -as the standard deviation suggests, very broad and flat. The distributions of grains anong cells look, again, like overdispersed Poissons.

$0^{6}-\mathrm{MT}$ data are avallable for both $G_{0}$ and cycling cells. The mean for cells in $G_{0}$ is $101.2 \pm 43.6$ frooles per $100 \mu$ pgn protein (range 15 to 230 ). That for cells tested $72 \mathrm{hr}$ after PHA-stimulation is $110.4 \pm 49.4$ fmoles. Thus not only are the levels quite variable, but the means are not different between the $G_{0}$ and the $72 \mathrm{hr}$ cells. However, the levels of $0^{6}-\mathrm{MT}$ do appear sonewhat correlated within subjects, with those with lower unstimulated values tending to have lower stimulated values and vice versa $(r-0.4)$. For lyuphocytes treated with MNNG in $G_{0}$, the SCE mean is $13.9 \pm 3.3$ SCE per cell (range 9 to 30 ); when treated in $G_{1}, 24 \mathrm{hr}$ after PHA stimulation, the mean is $21.1 \pm 5.0$ sCE per cell (range 13 to 32 ). These (and that for Myc-treated cells given below) may be compared with the untreated mean of $11.3 \pm 2.1$ SCE per cell (range 8 to 18 ).

For MYC-treated lymphocytes, the SCE mean is $28.0 \pm 6.1$ SCE per cell (range 12 to 42 ).

While it is still early in our project study, we are studying the distributions of means for the various endpoints and repeat-sampling subjects showing extreme values to assess the degree to which they may represent cases of constitutionally extreme response, as well as determining correlation. between different endpoints to assess their relationships.

Tesearch supported by U.S. DOE Contract DE-ACO2-76CHOOO16. 
Gene Specific DNA Repair in Resistant Mammalian Cell Lines. Vilheim A. Bohr National Cancer Institute, Bldg., 37 Rm 5C-25, Bethesda, MD 20892

Lately, there are a number of interesting dovelopments in the field of gene specific DNA repair. The characterization of human and bacterial genes that may play key roles in oene and strand specific DNA repair will be discussed in the introduction to our session, and other recent developments will be mentioned. Some of these have recently been reviewed (Bohr, VA., Carcinogenesis, November, 1991).

Through our studies on the mechanistic aspects of gene specific DNA repair, we have become interested in the role of this type of repair in different kinds of cellular resistance. In particular, we have studied mammalian cell lines that 1/ are resistant to plasmacytoma development and 2) that have developed drug resistance to chemotherapeutic agents.

Mice from the strain DBA are markedly resistant to induced plasmacytoma formation while mice from the BALB/C strain are susceptible. Plasmacytoma formation is invariably associated with rearrangements in the c-myc locus. We have recently reported a 5' c-myc repair phenotype that appears to be related to plasmacytoma resistance. The resistant mice have more efficiemt repair of UV induced pyrimidine dimers in the $5^{\prime}$ c-myc flank than the susceptible mice. This region is also where the translocations occur. The $5^{\prime} \mathrm{c}-\mathrm{m} y \mathrm{e}$ repair is not strand specific, and there is no Northern transcripts in this region (Beecham et al., MCB 11, 3095, 1991). We have now studied the $5^{\circ} \mathrm{c}-\mathrm{my}$ c repair in a number of inbred mice harboring DBA genomic regions on a BALB /c background. These strains were genorated by Dr. Michael Potter, NCl. So far, the repair phenotype with efficient $5^{\prime}$ c-myc repair was seen in all inbred strains that were plasmacytoma resistant, whereas those that were susceptible had no repair in the $5^{\prime} \mathrm{c}$-myc. This approach can be used to locate the gene for the repair which then might be the same as that for the plasmacytoma resistance. So far this mapping allows us to suggest that the locus may be on chromosome 4. In addition, we find similar sepair differences in other translocation regions, and this is presently under further study. We are also investigating whether these repair differences are seen in human Burkitts cells where similar translocations occur.

A common side effect of cancer chemotherapy is the development of drug resistance, and this has severe implications for the individual. Many mechanisms are thought to play a role in drug resistance, and DNA repair is one. So far, DNA repair studies in drug resistant cells have only been done at the level of the overall genome, and some studies show increased repair in resistant cells compared to the parental, but other studies show no difference (Link et al., Cancer Cells, November 1991). Wo have examined this question by studving DNA repair in human ovarian cancer cell lines that were resistant to cisplatin. Cisplatin induces two main lesions in DNA, the intrastrend adduct and the interstrand crosslink. We have studied the formation of repair of each of these lesions at the overall genome level and also in the DHFR gene (Weiping Zhen et al., submitted). After 24 hours, the removal of imterstrand crosslinks (studied by alkaline elution) and of intrastrand adducts (studied by atomic absorption) in the overall genome are similar in the resistant and the parental cell lines. The removal of intrastrand adducts from the DHFR gene is similar in the two cell lines, but there are marked differences in the removal of the interstrand crosslinks. The resistant cells show more efficient removal of the interstrand crosslinks from the DHFR pene than the parental cells. These findings may indicate an important role for oene specific repair of certain lesions in drug resistance, but they cartainly suggest that more DNA repair studies be done at the gene level . 
Differential Repair in Developmentally Regulated Genes in Dictyostelium discoideum. Stanley K. Mauldin, Reginald A. Deering, Thomas M. Freeland, and Angela Z. Ling. Department of Molecular and Cell Biology, The . Pennsylvania State University, University Park, PA, 16802.

The cellular slime mold Dictyostelium discoideum, a simple eukaryote with only 10-fold the genetic complexity of $E$. coli and $1 \%$ that of mammalian cells, provides a useful model system for characterizing DNA repair (Deering, in DNA Repair. Vol. 3 [Ed. by Friedberg \& Hanawalt], Dekker, 1988). During the starvation induced development of the amoeboid vegetative cells to form spore or stalk cells, various developmentally regulated genes are transcribed in a temporal sequence. Some are under the sontrol of cAMP. We have studied the removal of pyrimidine dimers from the prestalkspecific, cAMP-inducible cysteine proteinase 2 (CP2) gene. Two strains have been used: (1) a repair proficient strain NP2 and (2) a UV-sensitive mutant HPS64 (radC44). This mutant is not sensitive to other DNA damaging agents including ionizing radiation, alkylating agents, or psoralen plus light. Repair was analyzed in a 2054 bp Alu I fragment after 100 $\mathrm{J} / \mathrm{m}^{2}$ of $254 \mathrm{~nm}$ UV. This fragment contains the entire coding region of CP2 as well as the 5 transcriptional start and an upstream GC rich regulatory region. The production and removal of pyrimidine dimers was quantified in the Alu I fragment by using T4 endonuclease V, followed by alkaline agarose gel electrophoresis and Southern analysis. Comparison of the rates of dimer removal in NP2 showed no significant difference whether or not the CP2 gene was turned on by CAMP. In the UV sensitive mutant HPS64 (radC44) dimers were removed at about a six fold faster rate from the CP2 gene in the transcriptionally active state induced by cAMP relative to the transcriptionally inactive state. We currently interpret these results to indicate that $D$. discoideum has at least two repair pathways for coping with UV damage. One of these pathways is UV-specific, repairs dimers rapidly, and does not have a significant transcriptionally associated component, while a second pathway repairs dimers by a transcriptionally coupled mechanism. We suggest that the first of these is ineffective in the radC44 mutant allowing the second to predominate. (Supported by NIGMS 16620). 
Bderarchies of DWA repalr and biological consequences.

Leon B.I. Mullenders, HeC/Dopurtment of Radiation Gapetice and Chemical Vutagenesis, Undversity of Leiden. The Hetheriande.

Lepedr of the anor UV-Inducod photoleston 1.e. the cyclobutane pyrimidine dimer (CPD) has boen sbown to occur nonrandomly in the genome of mammilian ceI1s. In normal buman cells transcriptionally ective genes ere repeired Easter and more efflciently when compered to lasetive X-chromosomal genes or the berome overall.

Eoterogene1ty of CPD also existe at the level of tranocriptionally active genes since the transcribed otrand 18 much faster ropaired than the nontrasscribed etrand. Thls process of preferential repalr of the CPD in the transcribed strand is diroctly coupled to transcription. Epperiments performad with a SCID cell line lacklag trasscrlption of the Aderosine denminase geze revenled the absence of preferential repair of the transcribed strand. Bowever, the pethray directed to repals of CPD in the transcribed strand of active gente can operate in the absence of aigalflcant repalr of nontranscribed otrand of active genes of the genome overell. Thls wes deduced from experdments with rerodermn plgmentosum cells belongling to complomentation group C. Which are ouly capable to romove CPD from the transcribed strand of active genes. In contrast cells derfoed from

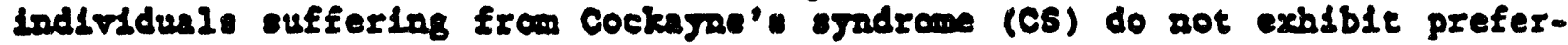
catial repalr of the trasscribed strand. Instead CPD repalr in transcribed and nontraiscribed trand in these cells resembles the repals of $X$ chromosomal inactive genes, euggesting that the factor(a) defective in CS govesn both rate and extent of ropair in ective genes.

Beterogenelty of DUA repalr has been show to play a olgalficant role in determiniag the crtotoric and mitagende effect of Diu damage in repair proflcleat and deficient cells. Both in sormsl humn and brmoter cells a etrand bias of UV-induced BIRT mutations tourards the non-transcribed strand correlates with preferontial removal of CPD from the tranecribed strand of the IPRT gene. In the case of (nondividing) $20-C$ cello with a limited genome overall zepair cepacity the only moderate Uv-sensitivity could be explained by the efficient repals of RrA-blocklog photolesions in the transeribed strand of active genes. However the expected bias of ov-induced matations towards the nontranecribed strand in the upRT gene was zot observed in 1 juphoblestold XP-C cells. 
UNUSUAL FEATURES OF DNA EXCISION REPAIR IN XP GROUP C CELLS.

D. Hunting and M. Carreau, MRC Group in the Radiation Sciences, Faculty of Medicine, Universite de Sherbrooke, Sherbrooke, (Quebec), Canada J1H SN4

Xetoderma pigmentosum group $\mathbf{C}$ cells have several interesting and somewhat puzzling characteristics. They repair only 10-20 percent of UV-induced damage but their survival compared to normal cells is much better than would be expected given this level of repair. Several years ago, Mansbridge and Hanawalt reported that XP-C cells repair only certain DNA comains following UV damage, thus resulting in clusters of repair patches which can be detected by digestion of purified DNA with T4 UV endonuclease, followed by separation on an alkaline sucrose gradient. They also noted that repaired DNA from XP-C cells shows an anomalous shift to a higher density in neutral $\mathrm{CsCl}$ gradients and suggested that repair either occurs in more GC rich regions in these cells or that some structural feature of the repaired domains renders them more dense in neutral gradients. Cleaver (1986) has reported that UV-induced repair patches are clustered in confluent XP-C cells but are randomly distributed in growing cells, even though the amount of repair is the same in both situations. It has recently been shown by Venema et al (1991) that XP-C cells selectively remove pyrimidine dimers from the transcribed strand of active genes. Nevertheless, the level of repair in XP-C cells appears to be higher than required if repair were limited only to transcribed strands of active genes. We find that UV-induced repair in confluent XP-C cells is strongly inhibited by alpha-amanitin, which has little effect on repair in normal cells. Surprisingly, Cot analysis indicates that repair synthesis occurs in all classes of DNA sequence, including highly repetitive. We have also studied the repair process in XP-C cells using alkaline elution and non-linear regression analysis. When repair synthesis is blocked by aphidicolin single strand breaks are formed as repaiz proceeds. At early times, the elution kinetics indicate a single population of DNA lengths, but as incision proceeds two populations emerge: a major population with few breaks, representing the unrepaired DNA between the repaired domains and a smaller but growing population with many breaks, rep esenting DNA from repaired domains. The results suggest that there are at least 2000 repaired d imains per cell, based on the strand break frequency in the major, unrepaired DNA population. 
Cellular Responses to Environmental DitA Damage

Identification of Specific DWA Repair Domains in XP Group C Cél1. G. J. Kantor, Department of Blological sciences, Wright state University, Dayton, OB.

Cultured fibroblasts from xeroderma pigmentosum complementation group $C$ patients have a very linited DiA excision repair activity, about 5-10s of that found in normal cells after exposure to ultraviolet Ilght (UV, 254 an). This 1imited activity is directed, not at randomly located DNA damage, but at the damage in epecific relatively large (> $30 \mathrm{~kb}$ ) chromatin regions. We have Identified several genes that are preferentially associated with these "repair domains" and two that are not. Experimentally, DNA free of pyrinidine dimers as a result of repair 18 separated from diver-containing DiA on the basis of its larger ize after DWA digestion with a Uendonuclease. Equal amounts of the repaired and unrepaired DNA fraction are alot-blotted and screened with gene-specific probes. Some of the genes Identified with the large domains Include small ones (B-actin, $3.5 \mathrm{~kb}$; c-myc, $8 \mathrm{~kb}$; Insulin, 1.4 $\mathrm{kb})$. Others such as DEFR, C-fms and ada are large and may approximate the ize of the repaired domains. A probe for a natrix-associated DLA region (MAR) also preferentially associates with the repaired DiA. Probes for B-globin and 754 do not preferentially assoclate with the repaired DNA. Based on these data, and measurements of repair rates in opecific DNA fragments, we conclude that genes associated with these specific domains are preferentially repaired and those not associated remain unrepaired. The data suggest that some mall genes are repaired as part of much larger chromatin domains. We invoke a consensus domain model for eukaryotic DNA organization and propose that the repaired domains in XP-C cells represent extended domains, each of wich includes at least one transcriptionally active region. The DIA of these domains is extended by multiple associations of the nuclear matrix with MARs, sequences also associated with transcriptionally active regione. Unrepalred domains are DiA regions condensed into higher order chromatin structures, nost of which remain transcriptionally inactive. We propose that the repaired DWA in XP-C may represent that chromatin subset that is enriched not only in active but also potentially active DiA. 


\section{Molecular Analysis of Xeroderma Pigmentosum Group A}

Kiyoji Tanaka, Ichiro Satokata, Hiroshi Asahina, Iwai Miyamoto, Naoyuki

- Miura, Kunimitsu Iwaj

Institute for Molecular and Cellular Biology, Osaka University, Osaka 565

Japan.

We cloned human DNA repair gene which complements the defect of group A xeroderma pigmentosum(XP) and named it XPAC gene(XP group A Complementing gene). Human XPAC cDNA encodes a protein consisting of 273 amino acids. The expected $M W$ of the protein is about $31 \mathrm{KDa}$ and it contains a $\mathrm{C} 4$ type zinc-finger motif.

We produced a recombinant XPAC protein in $E$. coli using PET-3C expression vector. The expected protein was a fusion protein with 14 extra amino acids of bacteriophage $T 7$ major capsid protein. Microinjection of a recombinant XPAC protein into group A XP cells restored their UV-induced unscheduled DNA synthesis(UDS) to the normal level. The gel retardation assay using 80 mer oligonucleotides as probe revealed that a recombinant $X P A C$ protein binds to DNA.

Rabbits were immunized with the purified recombinant XPAC protein to obtain anti-XPAC antiserum. We used immunoprecipitation analysis with anti-XPAC serum to identify the XPAC protein in the cells. On SDS-PAGE analysis, two proteins with relative molecular mass of $40 \mathrm{KDa}$ and $38 \mathrm{KDa}$ were specifically precipitated from preparations of normal human cells but no specific proteins were precipitated from the preparations of group A(XP2OSSV) cells.

In order to assess in detail the structure and function of the XPAC protein, we made various mutants by site-directed mutagenesis and isolated permanent transfectant cells. Immunofluorescent analysis of such lines indicated that nuclear localization signal was located in Exonl. But, Exonl was not essential for DNA repair activity. As contrasted with Exonl, other regions from Exon2 through Exon6 were essential for DNA repair function. Futhermore, replacement of one out of four cysteines supposed to form a zinc-finger st ucture in Exon3 with serine showed a severe loss of the repair activity to the same level to each other.

To examine the molecular basis of group A XP, human XPAC gene was cloned from normal and XP2OSSV cells. Human XPAC gene is about $25 \mathrm{~kb}$ long and is split into six exons. Comparison of the nucleotide sequences of multiple M13 clones of the XPAC gene from group A XP cells with that of normal human cells revealed that there are three kinds of mutations of the $X P A C$ gene in Japanese group $A X P$ patients. These are $G$ to $C$ transversion at the 3' splice acceptor site of intron 3 , and two nonsense mutations in exon3 
and 6 of the XPAC gene. All these mutations can be detected by means of RFLP of PCR-amplified genomic DNA fragment. The frequency of these mutated alleles in Japanese group A XP patients was

- $85 \%, 4 \%, 13 \%$,respectively.

We are trying to make a model mouse for group $A$ XP by gene targeting method in mouse ES cells. According to Capecchi's positive-negative selection method, we constructed a replacement type targeting vector which contains $5 \mathrm{~kb}$ of mouse XPAC genomic DNA fragment, pMC1 neo poly $\mathrm{A}^{-}$ and HSV-TK genes. We recently obtained the homologous recombinants. Construction of chimeric mouse is in progress. 


\section{CHARACTERIZATION OF ERCC2 AND ITS CORRECTION OF XERODERMA PIGMENTOSUM GROUP D. \\ C.A. WEBER, L.H. THOMPSON, \& E.P. SALAZAR, Biomedical Sciences Division, Lawrence Livermore National Laboratory, Livermore, CA 94550 (USA)}

- The UV-sensitive Chinese hamster ovary (CHO) cell line mutant UV5 has a defect in the incision step of nucleotide excision repair. This same process is defective in cells from patients with the cancer-prone genetic disorder xeroderma pigmentosum (XP). Genomic and CDNA clones of the human ERCC2 (Excision Repair Cross Complementing) gene, which complements UV5, have been isolated and characterized (Weber et al., 1988, Mol. Cell. Biol. 8:1137-1146; Weber et al., 1990, EMBO J. 9:1437-1447). Comparison with yeast nucleotide excision repair genes revealed strong homology with RAD3, suggesting ERCC2 is also an ATP-dependent helicase.

To determine whether any of the XP complementation groups have a defect in ERCC2, CDNA expression plasmids were constructed for use in functional complementation of XP cells. A complete CDNA was constructed in a vector with the strong SV40 early promoter, and a second construction added a neo gene. These clones fully restore UV-resistance to UV5. A differential cytotoxicity assay was conducted with cells from XP complementation groups $C$ through $H$. This assay demonstrated specific correction of two XP group D cell lines and of XP group $H$ cells. The correction of group $\mathrm{H}$ cells indicates that this patient is in fact a representative of group D as reported Johnson et al., Hum. Genet., 1989, 81:203-210; Vermeulen et al., Mutat. Res., in press). Groups A and B were not tested as they are known to be corrected by the XPAC (Xeroderma Pigmentosum group A Complementing) and ERCC3/XPBC genes, respectively (Tanaka et al., 1989, PNAS 86:5512-5516; Weeda et al., 1990, Cell 62:777-791). Stable transformants of two immortal XP-D cell lines have been isolated. UV-survival curves indicate nearly complete to complete correction in most cases. Thus, it appears likely that a defect in the ERCC2 gene is responsible for the nucleotide excision repair deficiency in XP group $D$ patients.

Partial sequence determination of ERCC2 CDNA from one XP-D cell line (A31-27) has revealed a Leu $\rightarrow$ Val substitution within helicase domain II at position 461 in one allele. The analogous residue in RAD3 is Ile. Studies are underway to assess the specific molecular alterations in cells of representative XP-D patients. Of particular interest is the patient previously designated XP group $H$ since this patient has clinical symptoms of both XP and Cockayne syndrome.

About $20 \%$ of patients with trichothiodystrophy (TTD), a rare autosomal recessive disorder characterised by brittle hair, mental retardation, and growth retardation, have been reported to show sun-sensitivity. In at least some of these patients, the sun-sensitivity is due to a defect in the same genetic locus that underlies XP group D. However, these patients do not exhibit other clinical features of XP such as skin cancers and alternating patches of hyper- and hypo-pigmentation. Future studies include determining the relationship of ERCC2 to the TTD gene and assessing the specific molecular alterations in ERCC2 in sun-sensitive TTD patients. Work performed under the auspices of the U.S. Dept. of Energy by LLNL (contract \#W7405-ENG-48). 
MOLECULAR ANALYSIS OF GENES INVOLVED IN MAMMALIAN DNA REPAIR

-

$\therefore$ Christine Troelstra, Marcel Koken, Geert Weeda, Peter van der Spek, Joke van den Berg, Jan H.J. Hoeijmakers, Dick Bootsma

Department of Cell Biology and Genotics, Medical Genetics Center, Erasmus Univershy Rotterdarn, PO Box 1738, 3000DR Rotterdam

Recombinant DNA technology has led to a considerable progress in various areas related to DNA repair. The molecular cloning of the uvrABC genes from Escherichia coli provided the basis for a detailed understanding of the prokaryotic excision repair mechanism. For eukaryotes, the list of genes involved in DNA repair is rapidly growing. Two approaches have been used by us to isolate mammalian DNA repair genes: DNA mediated gene transfer to repair deficient mutants and evolutionary walking based on nucleotide sequence homology.

Genomic DNA transfection resulted in the isolation of three human excision repair genes: ERCC-1, -3, and -6. ERCC-1 specifically corrects UV and MM-C sensitive CHO mutants from complementation group $(\mathrm{cg}) 1$. The gene (chrom. loc. 19q13.2, close to ERCC-2; 15-17 kb) encodes a protein of 297 aa. The central part, including a putative DNA binding domain, has significant homology to the yeast repair protein RAD10. The C-terminus, not present in RAD10, shares homology with parts of UvrA and UvrC from $E$. coli. Deletion analysis showed the central and C-terminal part (upto aa292) to be essential for correction. Domain swapping indicated that the C-terminus of UvrC has diverged too much from its human counterpart to permit functional substitution.

The ERCC-3 gene (chrom. loc. 2q21, $45 \mathrm{~kb}$ ) was isolated by virtue of its ability to correct CHO mutants of $\mathrm{cg} 3$. It encodes a protein of 782 aa; the deduced a sequence suggests it to be a chromatin binding DNA helicase. There is no homology to known DNA repair genes from yeast or $E$. coli, although the gene is strongly conserved. Using ERCC-3 probes, the yeast (S. pombe and S. cer.) homologs have been cloned. The ERCC-3 gene is found to be responsible for XP complementation group $B$, a very rare form of XP that is simultaneously associated with Cockayne's syndrome. Using the gene, two new patients have been assigned to this group, revealing a remarkable clinical heterogeneity within XP group B.

ERCC-6 specifically corrects the (moderate) UV sensitivity of CHO mutant UV61, a member of rodent $\mathrm{cg} 6$. This mutant harbours a partial deficiency in the repair of UV-induced cyclobutane pyrimidine dimers but permits apparently normal repair of (6-4) photoproducts, suggesting that the defective protein is involved in lesion recognition. The gene has a for transfection cloning respectable size of $\geq 85$ kb, contains relatively few repeats, and is spread over at least 21 exons. It encodes 2 very lowly expressed mRNAs 16.5 and $8.5 \mathrm{~kb}$, due to alternative polyadenylation) and a predicted protein of 1493 aminoscids with putative domains for nucleotide $(2 x)$ and chromatin binding and with an allmost perfect match with 7 consecutive motifs conserved between 2 superfamilies of helicases. This makes ERCC- 6 the third likely helicase involved in excision repair, the others being XPDC/ERCC-2 and XPBC/ERCC-3. The gene (chrom. loc. 10q11-21) was found to reside in a region deleted in one of the alleles of a CS patient. Subsequent transfection experiments indicated that ERCC- 6 specifically and efficiently corrects the UV sensitivity of CS group B cells. Hence, ERCC- 6 appears to be the first gene 
cloned that is specifically implicated in the important process of strand selective repair of active genes. Resuks on mutation analysis of CS patients and correction of different CS repair parameters will be discussed.

By evolutionary walking, we have cloned two human homologs of the Saccharomyces cerevisiae RAD6 gene, HHR6A and HHR6B (chrom. loc. Xq24-25 and 5q23-31, respectivelyl. The yeast RAD6 gene plays a central role in postreplication repair, damage induced mutagenesis and sporulation and encodes a ubiquitin-conjugating $\left(E_{2}\right)$ enzyme that may be involved in histon degradation and modulation of chromatin structure. Recent findings with respect to structure, expression, evolutionary conservation and function of the human genes will be presented (in collaboration with dr. L. and S. Prakash, Rochester). 


\title{
UV and X-Rar Sendtive CaO Mutants; Properties and Propreas in Gene Cloning
}

\author{
O.F. Whitmore, Ontario Cancer Institute \\ Toronto, Ontario, Cansda \\ $\therefore$
}

For some time we and others have been interested in the use of ropatr deficient CHO cells as tools in the study of DNA repair and mechanisms of drug action and as vehicles for the cloning of human DNA repair genes. Our primary interest has focused on two cell lines: the UV-4l line (isolated by Dr. LH. Thompson) which is sensitive to UV, extremely sensitive to cross-linking agents such es mitomycin $C$, shows very little seasitivity to ionizing radiation and is defective in the incision step of excision repair. The second line, V3/XRS-TI (isolated by us) is sensitive to x-rays and agents bnown to produce dorble strand breaks, shows normal sesistance to UV and is defective in rejoining DNA double strand breaks.

Initial atternpts to complement the deficiencies in both cell lines using genomic Hela DNA were successfiul in the case bf UV-41, but unsuccessful in the case of V3/XRS-T1. However, even in the case of successfinl UV 41 transformants, these seem to lack a closely linked human repetitive sequence which could be used to track the gene through subsequent cloning steps. Given the above situation, we began transfections of both cell lines using a human CDNA library in plasmids, provided by Dr. Okayama, in which the CDNA insert is bounded by both BAM-II and Xhol restriction sites. Transfection with this library was successful with both recipient cell lines. Following successful transfection we have constructed $\lambda$ libraries from both transfectants, screened clones for the presence of plasmid requences and tested positive clones for ability to confer repair proficiency. In the case of V3/XRS-T1, one clone capable of confecring resistance has been isolated and reotriction analysis shows that it contains BAMFI and Xhol fragments of 3.4 kbp. Attempts to establish the biological activity of these fragments are proceeding. 
ATAXIA-TELANGIECTASIA: Inkage evidence for genetic heterogeneity

R.A. Gattl

Department of Pathology, UCLA School of Medicine, LOs Angeles, CA

We reported linkage of Group A ataxla-telanglectasia (ATA) to chromosome 11q22-23, on the basis of significantly elevated LOD scores, using two polymorphic DNA probes (THY1/Mspl and D11S144/Mspl) and elght Group A families (Nature

536:577, 1988). Unexpectedly, even higher LOD scores were Obtained with both genetic markers when data from all AT families were combined; this included families whose complementation groups had not been determined, and three families who had been assigned to Groups C and V1. Tests for genetic heterogeneity within the original 31 families were inconclusive. Wo have since developed a high-resolution physical (Canc Genet Cytogenet 46:1,1890) and 18-point linkage map of a 70-cM reglon around the two original markers (Foroud ot al. Amer J Hum Genet Dec 1991). We confirmed linkage to an AT locus at $11 \mathrm{~g} 23$ with ten additional markers and further localized AT to a $2.8 \mathrm{cM}$ support interval midway between stromelysin (STMY) and D11S132. In collaboration with Shiloh and coworkers (Genomics 9,373, 1991), we studied a large Israeli Group C pedigree, again by linkaje ana!ysis, and obtained significant LOD scores with several of the same 19 q23 markers.

In 1990, Komatsu of al (Mutat. Res 235:59, 1990) and Ejima of al (int J Radiat Biol 58:889, 1990) reported correcting the radiosenstitity of an SV40-transformed Group D AT fibroblast line by introducing normal chromosome 11 and $11 \mathrm{q}$, respectively, into the cells. Friedberg of al recontly reported the functional complementation of the same Group D fibroblast strain by transfer of microcell DNA containing human chromosome 18 and "materlal from the region 11q22-23" that presumably includes DNA between D115132 and NCAM but not much proximal or distal to those markers (PNAS USA 88:5907, 1991). Kapp, Murname, Painter and colleagues report (seo Murname of al abstract this meeting) the cloning of a putative Group D gene that appears to map botween THYY and D1 1S83, (1.0. 20-30 CM distal to the [STMY-D1 IS132] region).

Together, complementation groups A $(55 \%), C(28 \%)$ and D (14\%) comprise $97 \%$ of assigned AT famllies (Cytogenet Coll Genet 49:259, 1988). We waro interested as to Whether location score estimates derived by Monte Carlo simulation (Lange and Sobel, Amer. J. Hum Genet. Dec. 1991) on 95 families in the International AT Consortlum could bo used to test for penetic heterogenelity by calculating location scores for subsets of these familios. When only known Group A and C familles were used (24 families), the [STMY-D11 1 132] peak remained the most likely location (lod score =17); the next most kely interval was 100:1 loss IIkely. A second peak between D11S147 and D11S133 that was observed when aly families were used (Amer J Hum Gonet Doc 1991), was no longer present. When known Group A and C families were omitted from the analysis, the second peak increased by 3 logs, suggesting that a third group (most likely Group D) links to the [D11S147-D1 1S133] interval rather than to the more pruximal [STMYDi1S132] region. 


\section{CLONING AND CHARACTERIZATION OF A PUTATIVE ATAXIA-TELANGIECTASIA GENE}

- I N. Kapp, R B. Painter, L.C. Yu, N. van Loon, C. Richard and J. P. Murnane, Laboratory of Radiobiology and Environmental Health, University of California, San Francisco, CA .94143-0750

Ataxia-telangiectasia (AT) is a human autosomal recessive disease that exhibits progressive neuromuscular problems, immunndeficiencies, a high incidence of lymphoreticular cancer, and sensitivity to ion-iug radiation. Cells from patients with AT also demonstrate radioresistant DNA syeinesis, which has been used to establish the presence of multiple complementation groups within this disease. Using the sensitivity of AT cells to ionizing radiation, we attempted to complement the defect in an AT cell line from complementation group D (ATSBIVA) by transfection with a human cosmid library containing a selectable neo gene. As previousty reported (1), the combined selection with both ionizing radiation and G418 resulted in the isolation of an AT cell line (1B3) which was partially resistant to ionizing radiation but remained similar to AT cells with respect to radioresistant DNA synthesis. The rescue of integrated cosmid sequences within 1B3 was accomplished by constructing a cosmid library, followed by selection with kanamycin for the neo gene contained within the transfected DNA. In situ hybridization demonstrated that the human DNA contained within two overlapping cosmid clones (K1 and K41) originated from chromosome region 11g23, previously shown to be the region containing the AT gene(s) from multiple complementation groups (2-5). The isolation of an apparent full-length $3.0 \mathrm{~Kb} \mathrm{cDNA}$ from a HeLa cell library demonstrated a previously unidentified gene within the cosmid DNA. The integrated copy of the gene is truncated at the $3^{\circ}$ end, however, it appears to be a functional transcription unit due to the presence of SV40 termination sequences in the adjacent cosmid DNA. Screening of a chromosome 11 cosmid library resulted in the isolation of a contiguous clone which contained the missing portion of the gene. Southern blot analysis indicated that this is a single copy gene, but Northern blot analysis showed at least 5 different sizes of mRNA $(5.7,4.7,3.0$, $2.6,1.8 \mathrm{~Kb}$ ) which varied among different cell lines. Neither Southern nor Northern blot analysis showed distinct differences in the AISBIVA cell line, which indicates that any alteration in this gene involves a point mutation or small rearrangement. Attempts to prove the identity of this gene by complementation have been complicated by the large size of the gene and the presence of multiple mRNA transcripts, however, some ATSBIVA clones transfected with the $\mathrm{K} 1$ cosmid (1 of 50) or the $3.0 \mathrm{~Kb}$ cDNA in an expression vector (6 of 33) demonstrated small increases in radioresistance. Additional experiments are required to test complementation with cosmids containing the intact gene and CDNAs from the larger mRNAs transcribed from this gene. Fine mapping of the location of this gerie using $x$-ray hybrid cell lines containing various portions of the 11923 region demonstrated close linkage to Thy 1 . The gene for AT complementation group D, therefore, appears to be located distal to the region predicted by linkage analysis to contain the AT gene(s) for complementation groups A and C (3-5).

1. Kapp, L and Painter, R (1989) Int. J. Radiat. Biol. 56: 667-675.

2. Lambert et al. (1991) Proc.Natl. Acad. Sci 88: 5907-5911.

3. Gatti, R (1991) Adv. Cancer Res. 56: 77-104.

4. MeConville et al (1990) Nucleic Acids Res. 18: 4335-4343.

5. Ziv et al. (1991) Genomics 9: 373-375. 
Abstract for Ronald $\nabla$. Hart presentation, MACR Special Conference on. Cancer Research: "Cellular Responses to Environmental DNA Damage" to be hèld In Banff, Alberta, Canada, December 1-6, 1991

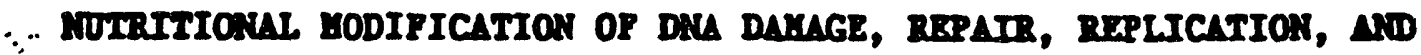
roprassioi

In understanding the effects of environment on cells and organisms generally, nutrition appears to be the nost important influence. The constituents of the diet are critical factors in chronic disease and Induced roxicity. Also, nutrition is a key nodulator of response to other enfironmental agents. Studies using caloric restriction and other nutritional modulations are discussed which show that alterations in behavior, physlology, hormonal status and metabolism occur vith nutritional alterations. These factors appear to influence the extent of DNA damage, DNA repair, and fidelity of transcription. Furthermore, changes in promotion and cellular proliferation suggest that nutritional alterations also impact on expression of DWA damage in a toxic endpoint. Caloric restriction is a useful tool in dissecting the wechanisms Involved in the relationship of DNA damage and disease, and for suggestIng methods to inhibit disease. 


\section{Abstract}

Title: Molecular analysis of the Werner syndrome mutator phenotype

Speaker: Raymond J. Monnat, Jr., Department of Pathology SM-30, University of Washington, Seattle, WA 98195.

(tel:206-543-6585/8540; FAX: 206-543-3644; E-mail: monnatcu. washington.edu)

We have recently identified several different types of genetic instability in cells and cell lines from Wemer syndrome (WS; McKusick catalog no. 27770) patients. These observations suggest that defective DNA metabolism plays a pathogenetically important role in WS, and that the WS genetic defect may be in a gene or genes involved in cellular DNA metabolism. WS is an autosomal recessive disease characterized by the appearance of features reminiscent of premature aging in young adults, including such ominous agedependent disease processes as neoplasia and cardiovascular disease. Although WS is phenotypically distinct from accelerated normal aging, the WS genetic defect does alter the rate of appearance of several clinically important, age-dependent disease processes. Thus delineating the WS gene defect and the role(s) of the WS gene product in cells should provide new insights into the pathogenesis of human age-dependent disease.

Deletion mutator phenotype in Werner syndrome cell lines. Our work began with identification of a 10-to-100-fold increase in the rate of spontaneous mutation at the X-linked hpr locus in cell lines derived from Werner syndrome patients. We subsequently showed that the WS mutator preferentially produced deletions at the hpr locus (Fukuchi et al. (1989) Proc. Natl. Acad. Sci USA 86:5893-5897). These deletions are the products of nonhomologous or illegitimate recombination between donor DNA duplexes that share little nucleotide sequence identity, can be as small as $230 \mathrm{bp}$, and do not differ in structure or complexity from spontaneous hprt deletions arising in control cells (Monnat et al. (1991) submitted). Thus the WS mutator can operate on small DNA targets, and most likely uses deletion mutagenesis pathways that are the same or similar to those used in normal cells.

Mutator phenotype in somatic cells of Werner syndrome patients. We have used two independent assays to identify the presence of a mutator phenotype in the somatic cells of WS patients. The first assay was a peripheral blood lymphocyte labelling assay in which HPRT-deficient T-lymphocytes are detected and quantified by virtue of their ability to incorporate radioactive thymidine after PHA stimulation in the presence of 6-thioguanine. These experiments revealed an 8-fold elevation in the frequency of labelled, thioguanineresistant T-cells in the peripheral blood of 5 unrelated WS patients as compared with 5 ageand sex-matched controls (Fukuchi et al. (1990) Hum. Genet. 84:249-252). The second assay uses a combination of fluorescently labelled mouse monoclonal antibodies to detect and quantify the amount of two common glycophorin A (GPA or MN bloodgroup) alleles on human red blood cells (Ron Jensen, Lawrence Livermore National Lab, pers. communication). We have recently used this assay to identify a $\geq 100$-fold elevation in the frequency of GPA allele-loss variant red cells in peripheral blood of a Wemer syndrome patient beterozygous at the MN blood group locus (Ron Jensen and R.J.M., Jr., unpublished results). The elevated "Nס" variant frequency we observed could be explained by an elevated rate of GPA " $M$ " aliele deletion or mutation without reduplication in erythroid 


\section{Werner syndrome mutator analysis}

precursors in this patient's bone marrow. These results are now being pursued using blood samples from additional WS patients, obligate heterozygotes and controls.

Wemer ondrome may be a human hyperrec mutation. The molecular structure of spontaneous hprt deletions arising in WS cells suggests that at least one nonhomologous or illegitimate recombination pathway is altered in WS cells. We are now examining both the activity and molecular products of the homologous recombination and gene conversion pathways in WS cells. In these experiments WS and control cell lines were derived that contained single, integrated copies of a plasmid vector containing two genetically inactive copies of the bacterial B-galactosidase gene (pLrec, developed by M. Steven Meyn, Yale). Multiple, independently derived WS and control sublines were then used to determine the conversion rate of cells to a lac ${ }^{+}$phenotype. Preliminary results suggest that WS sublines demonstrate a 5-to-10-fold higher conversion rate to a lac ${ }^{+}$phenotype than do comparable control sublines (M.S. Meyn and R.J.M, Jr., unpublished results). We are now analyzing independent lac ${ }^{+}$sublines to determine how frequently homologous recombination and gene conversion are used to generate genetically active $\beta$-galactosidase genes in these cells.

DNA replication and mutagenesis in Wermer cell extracts. There have been suggestions in the literature for over a decade that DNA replication and cell cycle progression are abnormal in WS cells. DNA replication obligatorily involves the production of single-stranded DNA and of single- and double-strand breaks that could be a source of slevated recombination, mutagenesis or cell death if inappropriately handled in WS cells. We are examining DNA replication in WS cells with an in vitro DNA replication system in which WS or control cytoplasmic extracts, when supplemented with SV40 large $T$ antigen $(T$ support bidirectional, semiconservative DNA replication of a plasmid DNA containing an SV40 replication origin. This system provides a functional assay for several extract proteins that play key roles in cellular DNA replication. Extracts prepared from both WS and control cell lines support high fidelity, T-Ag-dependent semiconservative replication of M13-SV40ori plasmid DNA (Khan Munir, Christine Beale and R.J.M., Jr., unpublished results). We are now determining the frequency and spectrum of mutations produced during in virro DNA replication in the M13-SV400ri-lacZ plasmid used for these assays.

The study of rare genetic diseases has told us a great deal about normal human biology: WS will be no exception. Understanding WS should help us to understand the control of replicative senescence and of mutagenesis in human somatic cells, and how these are linked to the pathogenesis of several clinically important, age-dependent human disease processes.

This work supported by grants AG01751 and CA48022 from the National Institutes of Health. 


\section{THE EFFECT OF AGING ON THE ACUTE PHASE RESPONSE: THE ROLE OF CIS-AND TRANS-ACTING FACTORS IN AGE-RELATED CHANGES OF THE ACUTE PHASE RESPONSE}

John Papaconstantinou, Minas Yiangou, Xin Ge, Tawfiq Alam and Ching Hsieh

Department of Human Biological Chemistry and Genetics, University of Texas Medical Branch, Galveston, Texas, U.S.A. 77550 and the Shriners Burns Institute, Galveston, Texas

Eukaryotic organisms possess natural defense mechanisms triggered by stress factors such as injury, inflammation, and infection. These mechanisms help to protect cells and tissues against further damage and to initiate restorative or regenerative processes. The regulation of some genes that respond to stress stimuli has been shown to be altered in aging and senescent cells. This is due, in part, to changes in activity of trans-acting factors that regulate their expression. One of these, the acute phase host response, is characterized by a series of hepatic physiological reactions triggered by factors released as a result of inflammation or tissue injury. We propose that (a) age-associated declines in tissue function may occur because of changes in the structure and function of these regulatory proteins and (b) the interactions of these factors with their respective cis-acting sequences are intrinsic processes whose alteration can occur in the absence of disease to produce biological characteristics of aging. It is our hypothesis that trans-acting factors of eukaryotic gene regulatory processes for genes that respond to stress may be intrinsic factors whose activities are affected by aging and that this could be the basis for either reduced or increased gene expression associated with aging. The regulation of many acute phase reactant genes has been demonstrated to occur at the level of both transcription and mRNA stability. Aging alters the regulation of several members of the acute phase protein family of genes as well as the heat shock protein genes. On the basis of these observations, we studied the effect of aging on the interaction of trans-acting factors with cis-acting DNA sequences of the $\alpha_{1}$-acid glycoprotein gene. The mechanism of regulation of the $\alpha_{1}$-acid glycoprotein will be presented as a model of how age-associated changes in gene activity may arise from alterations in regulatory factors. 


\title{
Endogenous DHA aductss role in carcinogenesis and ağing?
}

\author{
Kurt Randerath, Donghui Li and Erika Randerath
}

Division of Toxicology, Department of Pharmacology, Baylor College of Medicine, Houston, Texas 77030

\begin{abstract}
Covalent DNA adducts arising via different mechanisms can be detected by the highly sensitive ${ }^{32}$ p-postlabeling assay. This method does not require radioactive test substances, so it can be applied both to carcinogen-induced DNA adducts and I-compounds, i.e. spontaneous endogenous DNA modifications that increase with age without known carçinogen exposure. The assay entails enzymatic incorporation of ${ }^{32} \mathrm{P}-1$ abel into enzymatic hydrolysis products of DNA, followefd by chromatographic mapping and autoradiographic detection of $32 \mathrm{p}$-labeled products and quantitation by scintillation counting. Iimited amounts of cells or tissue can be examined, as only microgram amounts of DNA are required. Modifications of the basic assay afford enhanced sensitivities of adduct or I-compound detection. Under optimal conditions, a single aromatic/bulky adduct or I-compound in $10^{8}-10^{10}$ nucleotides can be assayed (corresponding to 0.3 - 30 amol/ug DNA or 0.1 - 10 nmol adduct/mol DNA-P). The assay has been applied to a variety of mutagenic (genotoxic) and non-mutagenic carcinogens (such as estrogens), as well as ,to I-compounds present in tissue DNA of untreated rodents.
\end{abstract}

I-compounds display age-, species-, strain-, sex-, and tissue-related chromatographic profiles and are modulated by diet. Caloric restriction (CR) is the most effective method to reduce incidence of cancer and degenerative diseases in rodents. Thus, the hypothesis was tested that CR would lead to reduced Icompound levels. Ad libitum (AI) fed and $40 \%$ calorically restricted male rats were examined up to an age of 30 months. Icompound levels in $A$ animals increased with age and plateaued at about 8 montis. At 24 months, I-compounds reached levels of 8.7 (1iver) and 27.4 (kidney) modifications in $10^{8}$ nucleotides, thereby exceeding the 1-month values by 3.7 and 16.6 -fold. $C R$ elicited similar profiles, but I-compound levels increased at a greater rate than in AI animals and exhibited a linear correlation overall with age up to 30 months. These results disproved the proposed hypothesis. Diet dependence of I-compound profiles was also demonstrated in rats fed natural ingredient (Teklad) or purified (AIN-76A) diet. Animals receiving the former diet exhibited more complex profiles and enhanced intensities of liver I-spots. Similar resuits were obtained for kidney, and overall spot profiles were different for liver and kidney. I-compound profiles, also, depend on hormonal status, as shown by pronounced sexual dimorphism observed in liver of untreated rats and by the 
findings that castration feminized and ovariectomy masculinized I-compound profiles and levels.

Various Iines of experimental evidence suggest that these DNA modifications are not derived from environmental genotoxic carcinogens, 1.e. (i) I-compounds do not exhibit chromatographic properties of DNA adducts derived from dietary carcinogens; (ii) rats, mice, and hamsters raised in parallel on the same naturalingredient diet display species- and tissue-specific I-compound profiles in liver and kidney DNA, but identical carcinogen DNA adduct patterns after exposure to one of several diverse carcinogens; and (11i) food restriction enhances, rather than reduces, I-compound levels in various rat tissues.

The adduct-like character of I-compounds prompted an investigation of the hypothesis that I-compound levels are increased during carcinogenesis. It was found that administration to rats of non-mutagenic hepatocarcinogens, 1.e. $2,3,7,8-$ tetrachlorodibenzo-p-dioxin (TCDD), choline-devoid diet, peroxisome proliferators, and carbon tetrachloride, substantially reduced, rather than increased, I-compound levels in the target organ. This reduction was due in part to decreased I-compound formation, and not merely to tissue injury and increased proliferation, as individual I-compounds were affected to different extents and I-compound loss persisted long after cessation of carcinogen-induced DNA replication. Consistent with these observations, I-compound levels were further diminished in various hepatomas. The extent of this deficiency did not correlate with tumor growth rates. Reduction of I-compound levels may thus be associated with altered gene expression and contribute to pathology. This interpretation is further strengthened by the observation that I-compound levels are reduced in organs of spontaneous tumorigenesis prior to the appearance of neoplasms. Conversely, enhanced I-compound levels induced by $C R$ correlate with the beneficial effects of this protocol, i.e. extension of Iife-span and retardation of age-related diseases. The combined results of our studies on the effects of various physiological and pathological factors on I-compounds support a possible antineoplastic and anti-aging role of these DNA modifications. 
Eugenla Wang, Lady Davis Institute for Medical Research, Montreal, Quebec, Canada

NEGATIVE CONTROL OF PROLIFERATION IN SENESCENT FIBROBLASTS • .

Orie of the most significant characteristics of senescent flbroblasts is thels permanent 1088 of abllity to engage in further ONA replication. Except efter Infection with SV40 virus, such loss is permanent and dominant. We and others have hypothesized that the irreversible inabillty to enter into coll-cycle traverse is controlled by Ying-Yang mechanism requlring llis Jestilivilion of growth-promoting gene expression, and activation of growth-inhlblting gene expresslon. Regarding the loss of growth-promoting gene products, Camplsi and her coworkers have reported the repression of c-fos gene expression, the necessary step for transcription events. On the negatlve side, Smith and his coworkers have reported the existence of Inhlbltory protein for DNA synthesis in senescent cells, by injecting the mRNA of old cei's into young growing counterparts. Alung this llne, Steln and her coworkers have repurted that RB gene product is not phosphorylated in senescent cells, and is therefore removed from the functioning pool needed for inltlation of transcriptional actlvatlon.

To support our hypothesis. of the activation of unlque senescence-speclfic gene expression, we have Identified a protein, statin, found only In nonprollferating cells. Our research so far has demonatrated that statin presence is a negative marker for growth status; i.e. the quantity of statin presence is inversely related to the proliferating state of any tissue. In tumor tissues, statin absence has been found to be an indicator of tumor malignancy. Molecular characterization of atatin has led to the Identifleation of a second nonproliferation-specific gene, 51, whose expresslon is shown by Northern anslysis to be tissue-specific for brain, heart, and muscle. Cenomic cloning and sequencing shows that $S 1$ is a member of a supergene famlly of EF-1a, an elongation factor of protein synthesis. Detalled analysis of the gene atruclure yluws that the two genes, SI and EF-1a, are two distinct members of thls family. SI gent expression is up-regulated upon serum starvation, while EF-1a is independent of Lhis culture manipulation. Quantitative analysis shows that EF-1a is at least twonty tImes as abundent as S1 in expression level. In S1-positive tlesues, therefore, this gene could not be simply serving as a substitute for the EF-1a gene. Rather, we hypothesize that SI gene is a complementary factor for EF-1a geno functlons, and may be involved in the translational control of essentlal piulelis which may in turn function as pivotel inhibitory proteins for the further synthesis of DNA, and thus render in vitro aged fibroblaste permanently dormant from cell cycle traverse. 
CIInical-faboratory Interactions in Investigating cellular Responses to DNA Damage. -- James German, The New York Blood Center, N.Y., N.Y. 10021.

sevefal rare recessively transmitted clinlcal entlties have been found to be interesting and valuable models for elucidating the mochanlams by whteh a somatic mammalian cell maintains its genome unnutated. Deficlency in maintenance of genomic stability 18. Iesture of comatic cel18 from persons with the cilnical disorders Bloom's syndrome (BS), Fancon's anemid, ataxiltelanglectasia, Werner's syndrome, and xeroderma plgmentosum (XP), and probably Cockayne's syndrome. All of these conditions had been described by observant clinlcians before 1960 but were obscure even in clinical medicine, they gulte naturally were virtually unknown at that time to students of the newly emerging fields of DNA repalr and mutagenes1s. From the early $1960 \mathrm{~s}$ on, one after another of these entities has proven experimentally useful in a variety of ways to students of DNA damage, DNA repair, mutagenesis, and neoplastic transformat1on. The 1dentifidation of human genet1c disorders that feature, and in some case are the conseguence of, genomic instablilty (e.g., const1tutionaliy unstable in BS, conditionally so in XP) made apparant the general importance for human blology of understanding mechanlisms of DNA replicatlon, damage, and repair; simultancousiy, 1t increased the number of students in these areas and the 1nterest in supporting investigation of such basic cellular mechanisms. An adventitious result of the unanticipated Interest shown by basic sclentists in these rare disorders has been a considerably 1noreased understending of the pathogenesis of disofders that previously had been largely neglected in clinical modicines this facliltates the diagnosis and management of affected persons and thereby makes the requisite cooperation between the clinlcian/geneticist and the families transmitting one of the rare mutations more rewarding for all concerned. The story of the elucldation of the Importance of DNA damage and repair in mammalian celis through an interplay of the clinical genetic1st/physlclan and the student of DNA repair is hlghly lateresting, Important conceptually, and worth recording. This interplay has helped emphasize the importance of the previous Iy neglected flelds of somatic cell mutation and somatic mutat lonal disease. For the future it promises to yield improved understanding in certain obscure but important areas of human blology that would not have been predicted three decades ago, in areas fuch as nervous uystem function and the pathogenes 18 of a number de common but poorly understood time-dependent (i.e., agedependor(t) disorders. 
How Many Repair Deficient Diseases and How Many Genes?, James E. Cleaver, $\therefore$ Laboratory of Radiobiology and Environmental Health, University of California, San .Francisco, CA 94143-0750.

Xeroderma pigmentosum (XP), Cockayne syndrome (CS), and trichothiodystrophy (TTD) are human hereditary disorders affecting repair of ultraviolet (UV) damage to DNA. XP patients exhibit increased erythema, freckling, actinic keratoses and eventual basal and squamous carcinomas on sun-exposed areas of the skin. Some XP patients also develop progressive neurological disorders including diminished deep tendon reflexes, sensorineural deafness and mental retardation; some are microcephalic and mentally retarded at or soon after birth. TTD patients exhibit brittle sulfur deficient hair, short stature, mental retardation and ichthyosis; some TID patients who exhibit sun sensitivity and reduced repair fall into XP group D. CS patients are sun sensitive, dwarfed and show progressive neurological disorders including retinopathy, deafness, retardation and ganglial calcification. Cellular complementation has led to the designation of 7 XP groups (A-G) that are defective in nucleotide excision repair and one group (V) defective in replication, and 2 CS groups (A, B) that are defective in repair of actively transcribed genes. This classification is complicated by the identification of patients with both XP and CS in XP groups B, D, and G, suggesting that the symptoms may not only be associated with mutations in specific genes but also influenced by overlapping developmental roles for a family of interrelated genes.

We have also identified up to 10 highly UV sensitive patients whose clinical symptoms range from mild erythema to severe sun sensitivity and neurological disorders, but who are different from either XP or CS. At the cellular level these patients do not exhibit any XP repair or replication deficiency but show failure to recover RNA synthesis after UV. These are currently being assessed for relationships to CS group $A$ and $B$, to determine if they represent additional complementation groups or unusual clinical phenotypes of known groups.

Underlying this phenotypic and genetic complexity, is a correspondingly complex photochemical problem involving multiple substrate types and genomic locations. The two major photoproduct classes, the cyc ubutane dimers and (6-4) photoproducts, show many differences in these respects. We have found that (6-4) photoproducts, in contrast to dimers, are formed preferentially in regions containing active genes, which explains in part their more rapid repair from bulk DNA and from active genes. An XP group A revertant we developed has normal UV resistance; this cell line excises (6-4) photoproducts but does not excise dimers from the whole genome or from an actively transcribed gene (dibydrofolate reductase, dhfr) after high UV doses (26 $\left.\mathrm{J} / \mathrm{m}^{2}\right)$. Human cells can therefore discriminate between the two major photoproduct classes, and (6-4) photoproducts may play a greater role than dimers in lethal effects 
of UV light. Quantitative PCR amplification of CDNA from the XPAC gene on chromosome 9 showed reduced message level in XP group A cells, but normal levels in the revertant. The original XPAC gene had a chain terminating mutation $(C \rightarrow T)$ in codon 207; the revertant had a further change in codon $207(T \rightarrow G)$ which restored the reading and resulted in a substitution of glyeine for arginine in the XPAC gene product. This observation has two alternative interpretations, both involving the XPA gene product in primary photoproduct recognition. Either (a) an amino acid change in this gene permits recognition of (6-4) photoproducts but not dimers, or (b) the change may be a null mutation and this gene normally codes for a (6-4) recognition protein, dimers being recognized by a different gene product. The latter interpretation would require two separate genes for XP group A. This can be reconciled with the classification of XP into complementation groups since these are defined by the restoration of unscheduled DNA synthesis in cell hybrids using short labeling times which pertains more to the genetic regulation of (6-4) repair than to dimers. Work supported by OHER, U.S. Dept. of Energy, contract no. DE-AC03-76-SF01012. 


\section{REIATIONSBIPS BETWELN YERODERMA PIGNENTOSOM, COCRAYNE' 8 8YLDRONA AND TRICEOTAIODYSTROPBY}

$\therefore$

A R InEmaid, MRC Cell Mutation Unit, University of Sussex, Falmer, Brighton BN1 9RR, UK.

M STEFANINI, Consiglio Nazionale Delle Ricerche, Istituto di Genetica Biochimica ed Evolizionistica, via Abbiategrasso, 207 - 27100 Pavia. ITALIA.

W VERMEULEN, Department of Cell Biology and Genetics, Medical Genetics Center, Erasmus University, PO Box 1738, Rotterdam, THE NETHERIANDS.

The relationship between defective excision-repair and the clinical symptoms of the resulting genetic disorders is becoming increasingly complex. Several patients with Cockayne's Syndrome (CS) also have the symptoms of xeroderma pigmentosum (XP). with its associated defects in overall excision-repair. The defects in these patients have been recently assigned to XP groups B, D and G. Of the CS patients with normal levels of overall excision repair, il have been assigned to CS group $B$ and 3 to CS group $A$.

Analysis of the DNA repalr characteristics of trichothiodystrophy (TID) patients has revealed a marked heterogeneity. Out of 24 cell strains examined, 7 showed a normal response, 12 were severely deficient in excision-repair, 2 were specifically deficient in the repair of 6-4 photoproducts and 3 had an intermediate response. The defect in most of the repair-deficient TTD cell strains can be assigned to XP group $D$, but the defects in two of the patients are not in XP-D. They may be in new complementation groups.

One of the most puzzling features of the above observations is that mutations in the XP-D gene which, result in apparently identical DNA repair defects in cultured fibroblasts can result in two cumpletely different disorders, XP and TTD. We previously proposed that the full clinical phenotype of XP might require not only a defect in excisionrepair, but also a second defect, possibly in the immune system. This proposal was based on observations that five XP patients had a defect in Natural Killer (NK) cell activity, whereas 1 TTD and 2 CS patients did not. More recent observations in several laboratories suggest that the deficiency in NK activity is not found in all XP patients, and it has been observed in some TTD individuals. A deficiency in some aspect of the immune system does, however, seem to be a regular feature of XP.

In order to test the two-mutation hypothesis for XP we have examined excision-repair in a large XP family.. as well as in some

immunosuppressed patients who develop multiple skin cancers. Although the results obtained so far do not rule out a two-mutation hypothesis, they do not offer it any support.

The ERCC-2 gene has recently been shown by $C$ Weber and colleagues to correct the defect in XP-D cells. We are currently analysing the ERCC-2 gene in TID patients to try to identify the predicted mutation. of 6TTD cell strains so far examined, none shows any gross changes in the structure of the XP-D gene. Sequence analysis is currently underway. 


\section{Cellular Responses to Environmental DNA Damage}

Radiosensitivity in Ataxda-telangiectasia: A New Explanation Involving Anomalous Signal Transduction. Malcolm C. Paterson. Molecular Genetics and Carcinogenesis Laboratory, Department of Medicine, Cross Cancer Institute, 11560 University Avenue, Edmonton, Alberta T6G 122, Canada.

The rare autosomal recessive disorder ataxia-telangiectasia (A-T) is characterized by diverse clinicopathological anomalies that include progressive neurovascular degeneration, recurrent sinopulmonary infection assoclated with variable immunodeficiency, impaired organogenesis and multiple endocrine dysfunctions $(1,2)$. Afflicted patients are also prone to lymphoproliferative neoplasms and solid tumors (3) and respond catastrophically to conventional radiotherapy $(1,2)$. Pronounced radiosensittvity extends to the cellular level in vitro. On exposure to ionizing radiation or free radical-generating chemicals (e.g., bleomycin, neocarzinostatin, phorbol myristate acetate, and calicheamicin $\left.\gamma_{1}^{\prime}\right)$, cultured A-T cells invariably display defective colony-forming ability and excessive chromosomal changes, especially chromatid-type aberrations $(1,2,4,5)$. [Chromosomal instability also occurs spontaneously, as manifested by an increased incidence of balanced chromosomal rearrangements involving sites containing T-cell receptor and immunoglobulin genes in peripheral T-lymphocytes from affected patients $(2,4,6)$.] The disease is genetically heterogeneous as evidenced by the identification of four complementation groups (denoted $A, C, D$, and E) (7). Both linkage analysis of RFLP markers and microcell-mediated chromosome transfer studies with families from known complementation groups have mapped AT-A, AT-C and AT-D lod to chromosome 11g22-23 $(2,6,8,9)$, indicating either a complex of three closely linked genes or possibly a single gene with structural alterations in distinct intragenic functional domains accounting for the different complementation groups.

The complexity of the A-T phenotype is also evident in other laboratory studies. Resistance to the inhibitory effects of radiation on DNA replication constitutes the only DNA metabolic deficit common to all A-T strains (10). Other anomalies variously seen in A-T cells include overproduction of DNA topoisomerase II (11), constitutive expression of a DNA-binding protein normally activated by $\gamma$ radiation (12), covalent modification of base-free deoxyribosephosphate residues by cell-free extracts (13), and increased bioreduction of the radiomimetic chemical 4-nitroquinoline 1-oxdde in combination with defective excision repair of alkali-stable DNA adducts produced by the resultant reactive metabolite (14).

Although the subject of intensive research during the past 15 years, the molecular basis of the marked radiosensitivity seen in A-T remains speculative and controversial. Independent lines of evidence over the years have pointed to malfunctions in: (i) a DNA repair pathway operative on free radical-induced damage to sugar or base moities; (ii) a specific DNA cutting or splicing enzyme, such as a recombinase; and/or (iii) a damage-recognition system that serves to arrest the DNA replication machinery until noncoding lesions have been removed from template DNA $(1,10,14)$. More recent data suggest, however, that the primary defect in A-T may reside in a regulatory gene whose product may control the expression of multiple homeostatic mechanisms $(1,14,15)$. More specifically, an increasing body of evidence demonstrating consistent anomalies in both extracellular matrix proteins (e.g., fibronectin and procollagenase) and various cytosolic particles (e.g., actin-containing microfilaments) $(1,16)$ has led McKinnon to postulate gross structural alterations in the cytoskeleton as the root cause (1). In addition, we have recently demonstrated that the DNA repair defect revealed as reduced araC site accumulation in A-T group A cells after $\gamma$ irradiation can be rectified by cocultivation with normal fibroblasts (without gap junctional intercellular communication), as can the well-known impairment in the inhibition of DNA synthesis following rray exposure. Likewise, the 
pronounced radiosensitive clonogenic survival of the same A-T cells can be partially overcome by coincubation with normal ibroblasts. These intriguing findings implicate the involvement of a diffusible factor. In parallel experiments, we have found that nontransformed fibroblast strains, derived from affected members of a kindred with the dominantly inherited Li-Fraumeni cancer family syndrome, display distinct cellular irregularities (Le., enhanced clonogenic survival and reduced mutation induction) on exposure to $\gamma$ rays. These radioresistant strains, which contain documented anomalies in both recessive (p53) and dominant (c-rof-1 and c-myc) oncogenes $(17,18)$, exhibit a modified pattern of post- $\gamma$ ray DNA replication opposite to that charncteristic of the radiosensitive A-T strains. Given that c-raf-1 and c-myc encode key components of mitogenic signal transduction pathways, our combined data suggest that (i) the transitory shutdown of DNA replication in human cells following radiation exposure is primarily controlled by a mechanism that may utilize elements of the membrane signalling and transduction circuitry governing normal cell growth and development land is controlled neither by DNA lesions per se nor by a cis-acting signal transmitted along the chromatin, as held by longstanding radiobiological dogma (see also refs. 19,20)]; and (ii) the striking multifaceted symptomatology of A-T may arise from a defect in this circuitry. [Research sponsored by NCI(C), Medical Research Council, Alberta Cancer Board, and Ataxia-Telangiectasia Medical Research Foundation. The author is a Medical Scientist of the Alberta Heritage Foundation for Medical Research.]

\section{References}

1. McKinnon, P.J. Hum. Genet. 75:197-208, 1987.

2. Gatti, RA., et al. Medicine 70:99-117, 1991.

3. Hecht, F., and Hecht, B.K. Cancer Genet: Cytogenet. 46:9-19, 1990.

4. Taylor, A.M.R. at al. Int. J. Radiat. Biol. 56:677-684, 1989.

5. Sullivan, N., and Lyne, L. Mutat. Res. 245:171-175, 1990.

6. Gatt, R.A. Adv. Cancer Res. 56:77-104, 1991.

7. Jaspers, N.G.J., et al. Cytogenet. Cell Genet. 49:259-263, 1988.

8. Ziv, Y., et al. Genomics 9:373-375, 1991.

9. Lambert, C. et al. Proc. Natl. Acad. Sd. USA 88:5907-5911, 1991.

10. Young, B.R, and Painter, R.B. Hum. Genet. 82:113-117, 1989.

11. Davies, S.M., et al. Nucleic Acids Res. 17:1337-1352, 1989.

12. Singh, S.., and Lavin, M.F. Mol. Cell. Biol. 10:5279-5285, 1990.

13. Karam, L.R., et al. Mutat. Res. 236:19-26, 1990.

14. Mirzayans, R., et al. Cancer Res. 49:5523-5529, 1989.

15. Aggeler, J., and Murnane, J.B. In Vitro Cell. Dev. Biol. 26:915-922, 1990.

16. Mizayans, R., and Paterson, M.C. Carcinogenesis 12:19-24, 1991.

17. Srivastava, S., et al. Nature 348:747-749, 1990.

18. Chang, E.H., et al. Science 237:1036-1039, 1987.

19. Lamb, J.R. et al. Int. J. Radiat. Biol. 56:125-139, 1989.

20. Cleaver, J.E., et al. Radiat. Res. 124:294-299, 1990. 

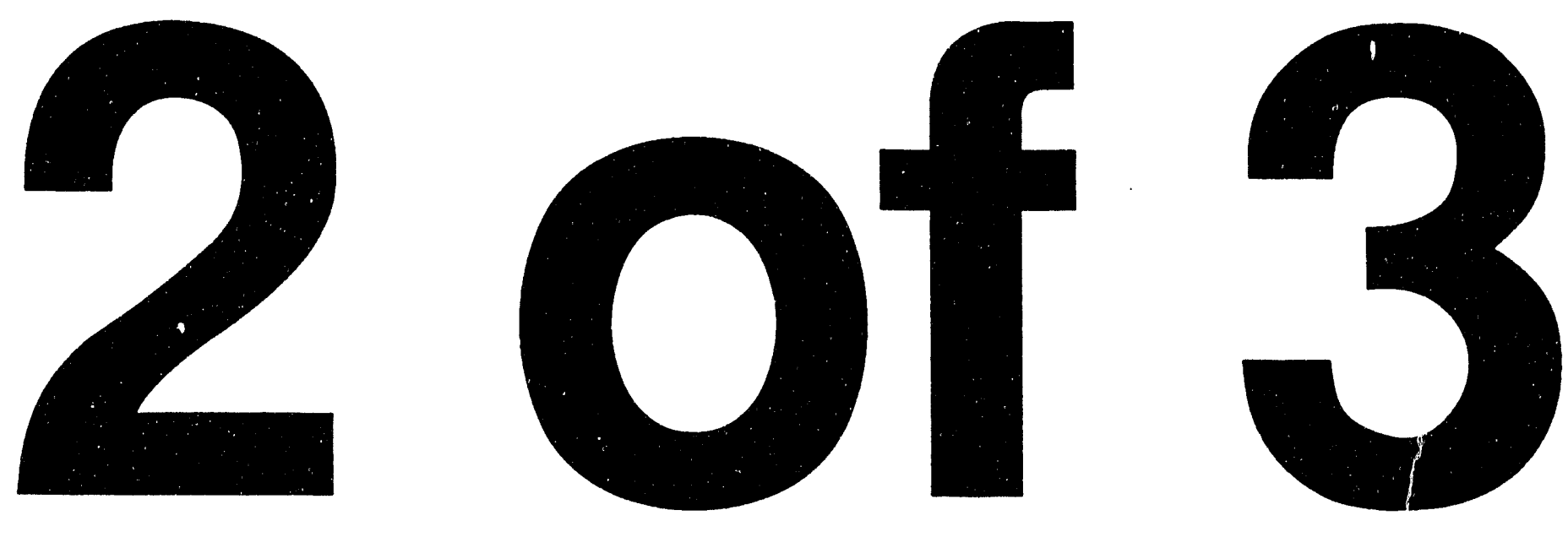


\section{USING RODENT CELL LINES AND GENES TO CHARACTERIZE AND MODEL}

HUMAN REPAIR DISORDERS

Larry Thompson, Keith Caldecoth, Kerry Brookman, and Rober Tebbs, Biomedical Sciences Division, Lawrence Livermore National Laboratory, Livermore, CA 94550

During the last several years there has been notable progress in characterizing genes involved in DNA repair processes in mammalian cells. The most fruitful approach has been the use of repair-deficient lines of rodent cells, especially CHO cells, as a means of identifying human genes that functionally complement the rodent-cell mutations. The nucleotide excision repair (NER) pathway, which acts on major UV photoproducts, is of special interest because it also repairs diverse bulky covalent adducts produced by environmental mutagens, including those associated with fossil fuels and cooked foods. The biochemical steps of damage recognition and incision in NER appear to require a large number of gene products. Ten genetic complementation groups of rodent cell mutants that are hypersensitive to ultraviolet (UV) radiation and defective in incision are now identified $(1,2)$. In comparison, seven complementation groups of incision-defective mutations are associated with the genetic disease xeroderma pigmentosum (XP). Although the rodent and XP mutants are phenotypically similar, two of the rodent groups (1 and 4) are extraordinarily sensitivity to DNA cross-linking agents (3). Mutants belonging to the first five rodent complementation groups all have a high degree of UV sensitivity and little or no repair, indicating that the genes involved are essential in the NER pathway. Mutants in groups 6-10 have intermediate degrees of sensitivity and partial repair. Complementation of UV-sensitive CHO mutants with human genes has been accomplished both by constructing somatic cell hybrids and by performing DNA transfection. Human genomic DNA transformation has lead to the cloning of five complementing human genes (ERCCI, $-2,-3,-5$, and -6 ), and several of these genes (ERCC2, -3 , and -0) appear to be involved in XP and/or Cockayne's Syndrome. Complementation analysis of rodent cell mutants having hypersensitivity to ionizing radiation has been used by others to define -10 genetic complementation groups $(4,5)$. The CHO mutant EM 9 was one of the first such mutants, originally isolated by its hypersensitivity to killing by ethyl methanesulfonate (EMS). EM9 is 10-fold more sensitive to EMS than wild-type CHO, 2-fold more sensitive to ionizing radiation, and is highly sensitive to selective medium that produces $20 \%$ replacement of dThy by ClUra in the DNA. The physiological phenotype of EM9 involves $=5$-fold reduced efficiency of rejoining single-strand breaks and a 10-fold elevated frequency of sister chromatid exchange (SCE) (6). The human gene that corrects the CldUrd sensitivity of EM9, XRCC1 (X-ray repair cross complementing), was cloned and found to restore the phenotype of EM9 to that of wild-type CHO cells for all end points discussed above (6). XRCCI maps to human chromosome 19q13.2-13.3, which is also the location of the ERCCI and ERCC2 genes.

A nearly full-length $\mathrm{CDNA}$ clone of XRCCI (pXR1-30) was recovered from the pCD2 expression library, but this clone only partially corrected EM9 (6). A comparison of the nucleotide sequence of this CDNA with that of the 5 ' end of the gene from a cosmid clone showed that the CDNA was missing 26 nucleotides of coding sequence. Translation of the complete open reading frame (ORF) gave a presumptive XRCC1 protein of 633 amino acids. Except for a nuclear location signal, XRCC1 did not have regions of homology with any of the protein sequences examined in the data bases. However, using an XRCC1 5'-end coding fragment, we identified hybridizing restriction fragments in both $E$. coli and $S$. cerevisiae DNAs on a Southern blot washed at high stringency $\left(0.1 \times\right.$ SSC, $\left.65^{\circ} \mathrm{C}\right)$. These results suggest that the XRCCI locus may be highly conserved between eukaryotes and prokaryotes. 
By extending the incomplete coding region of XRCCI CDNA and over-expressing the protein in a eukaryotic system, it should be possible to isolate and purify the XRCC1 protein.

- Therefore, appropriate synthetic oligonucleotides were used to construct a derivative of pcD2 (designated PCD2EX) in which the complete ORF was under the control of the SV40 early promoter. Transfection of pcD2EX DNA into EMQ produced a high frequency of correction in CldUrd medium, and the transformants grew at a normal rate under this selection. A CDNA construct containing the native $X R C C 1$ promoter and no introns also gave efficient correction. The functional $X R C C 1$ ORF has been introduced into malE expression vectors of $E$. coli to attempt to isolate a fusion protein for purposes of antibody production.

To study the degree of conservation of XRCCl in mammals, we used the human cDNA as a probe for cloning the homologous mouse sequences. From a $\lambda$ phage mouse brain library kindly donated by Dr. Jan Hoeijmakers, a 3'-end XRCCI cDNA clone of $=900$ bp was isolated and used to obtain the missing 5'-end cDNA sequences by the method of anchored polymerase-chain-reaction (PCR). The PCR product was cloned into the vector pBluescriptII KS(t) for nucleotide sequencing. Based on preliminary sequence analysis, the mouse XRCCI protein is 622 amino acids and $=87 \%$ identical to the human sequence.

The availability of cloned repair genes now offers the possibility of producing repairdeficient transgenic mice that can be used as models for human DNA repair disorders. Mutations in the human XRCCI locus have not been described. However, this locus may be suitable for making mutations that might confer a phenotype of deficient strand-break repair in transgenic mice. Toward this aim, we plan to introduce a null mutation into mouse embryonic stem cells using targeted recombination with a vector carrying a disrupted exon from the $5^{\prime}$ end of the mouse XRCCI gene. The disruption can be conveniently performed using the neo gene, which also provides a dominant marker for identifying transformants (7).

To design and construct a vector for targeted recombination, we have isolated mouse $X R C C I$ sequences from a genomic cosmid library generously provided by Dr. John Mudgett. Clones that restored CldUrd resistance to EM9 cells were identified, and all four of those tested gave nearly complete normalization of SCE levels. A restriction site map of one of these clones has been constructed to identify an appropriate genomic fragment that can be used for engineering the targeting vector.

This work was done under the auspices of the U.S. Dept of Energy by LLNL under contract No. W-7405-ENG-48.

1. Thompson, L. H. T. Shiomi, E. P. Salazar, and S. A. Stewart 1988. An eighth complementation group of rodent cells hypersensitive to ultraviolet radiation. Somat. Cell Mol. Genet. 14:605-612.

2. Stefanini, M. A. R. Collins, R. Riboni, M. Klaude, E. Botta, D. L. Mitchell, and F. Nuzzo. 1991. Novel Chinese haunster ultraviolet-sensitive mutants for excision repair form complementation groups 9 and 10. Cancer Res. 51: 3965-3971.

3. Hoy, C. A., L. H. Thompson, C. L. Mooney, and E. P. Salazar. 1985. Defective DNA cross-link removal in Chinese hamster cell mutants hypersensitive to bifunctional alkylating agents. Cancer Res. 45:1737-1743.

4. Thacker, J., and R. E. Wilkinson. 1991. The genetic basis of resistance to ionising radiation damage in cultured mammalian cells. Mutat. Res. 254:135-142.

5. Jeggo, P. A., J. Tesmer, and D. J. Chen. 1991. Genetic analysis of ionising radiation sensitive mutants of cultured mammalian cell lines. Mutat. Res. 254:125-133.

6. Thompson, L. H., K. W. Brookman, N. J. Jones, S. A. Allen, and A. V. Carrano. 1990. Molecular cloning of the human XRCCl gene, which corrects defective DNA strand-break repair and sister chromatid exchange. Mol. Cell. Biol. 10: 6160-6171.

7. Capecchi, M. R. 1989. Altering the genome by homologous recombination. Science 244:1288-1292. 
CELLULAR RESPONSES TO ENVIRONMENTAL DNA DAMAGE

oxidant Carcinogenesis, continued.

Peter A. Cerutti and Paul A. Amstad - Department of Carcinogenesis, Swiss Institute for Experimental Cancer Research, 1066 Epalinges/Lausanne, Switzerland.

Oxidants are ubiguitous natural carcinogens. They cause permanent alterations of DNA structure and the question arises whether they participate in the formation of point mutations in protooncogenes and tumor suppressor genes in human carcinogenesis. Genotypic mutation systems which allow the measurement of mutations in cancer genes without the expansion of mutated cells are required to explore this question. With this aim we are developing the RFLP/PCR protocol which measures base pair changes, small deletions and insertions in restriction recognition sequences and render this site resistant to cleavage by the corresponding endonuclease. The resistant DNA sequence containing the mutated site is amplified by PCR only after wild type DNA has been essentially eliminated by restriction digestion. Amplified DNA is directly sequenced or cloned into $\lambda$ gt 10 and mutants are quantitated by oligonucleotide plaque hybridization. Absolute mutation frequencies are estimated relative to an internal "mutant standard".

We analyzed spontaneous and ethylnitrosourea(ENU)-induced mutations in MspI-site 1695-1698 (CCGG(C), codon 12) and Taq-I site 2508-2511 (TCGA) of the c-Ba-ras1 gene in human fibroblasts. The RFLP/PCR protocol allowed the rescue of 5-10 mutated ras copies from 107-108 cells. ENU preferentially induced $G \rightarrow A$ transitions in the $T a g$ I-site and $G \rightarrow T$ transversions in the MspI-site. Evidence was obtained for spontaneous $C \rightarrow T$ transversions at the Cpg dinucleotide and $G \rightarrow T$ transversions in the Tag I recognition sequence. The former may result from the deamination of 5-methyl-cytosine while the latter may be caused by oxidative damage to guanine. The RFLP/PCR method holds promise for the early detection of mutations in restriction sites of disease-related genes in experimental research and biochemical epidemiology $(1,2,3)$.

Besides structural changes in DNA oxidants activate signal transduction pathways and transiently alter gene expression in particular of the immediate early genes c-fos, $c-m y c$ and $B$-actin. The induction of these genes appears to be required for the stimulation of cell proliferation in tumor promotion. In studies of the mechanism of the transcriptional induction of $c$-fos by oxidants we have identified the joint DSE-AP1 elements as major enhancer motifs in the $5^{\prime}$-upstream regulatory sequences of c-fos. Oxidants also increased the de novo synthesis of protein factors which bind to these enhancer motifs. Protein kinase- and ADPRtransferase inhibitors suppressed the transcriptional induction of $c$-fos as well as the increase in factor binding to 
DSE and fos-AP-1. We conclude that protein-phosphorylation and -polyADP-ribosylation are required for the transcriptional induction of $c$-fos and the synthesis of protein factors which bind to DSE-AP1. The FOS-and JUN-proteins are among these factors and it is likely that they participate in the regulation of c-fos expression by oxidants.

The cellular antioxidant defenses affect the consequences of oxidant exposure. Transfectants of mouse epidermal cells which overproduce $C u, 2 n$-superoxide (SOD) were sensi= tized to the toxic effects of an extracellular burst of $0_{2}$ plus $\mathrm{H}_{2} \mathrm{O}_{2}$ while overproducers of catilase (CAT) were protected. Transfection of SOD-overproducers with CAT corrected their hypersensitivity. Inducibility of the protooncogene c-fos by oxidants was diminished in SOD- and CAT-overproducers, albeit probably for different. reasons. It is concluded that a fine balance of the multiple components of the antioxidant defense determines the growth response of cells to oxidative stress $(4,5,6)$.

\section{REFBRENCES}

1. J. Zijlstra, E. Felley-Bosco, P. Amstad and P. Cerutti. In "Mutagens and Carcinogens in the Diet" pp. 187-200 (eds. Pariza et al). Wiley-Liss, New York (1990).

2. E. Felley-Bosco, C. Pourzand, J. Zijlstra, P. Amstad and P. Cerutti. Nucl. Acid Res. 19, 2913-2919 (1991).

3. M. Sandy, S. Chiocca and P. Cerutti, Proc. Natl. Acad. Sci., in press.

4. P. Cerutti and B. Trump, Cancer Cells 3, 1-7 (1991).

5. P. Cerutti, Eur. J. Clin. Invest. 21, 1-5 (1991).

6. P. Amstad, A. Peskin, G. Shah, M.-E. Mirault, R. Moret, I. Zbinden and $P$. Cerutti. Biochemistry 30, 9305-9313 (1991). 


\title{
THE ROLE OF MELANIN IN THE PHOTO- AND RADIOBIOLOGY OF MALIGNANT MELANOMA
}

\author{
Helene Z. Hill \\ Department of Radiology \\ UMDNJ-New Jersey Medical School \\ Newark, NJ 07103-2714
}

Melanins are ubiquitous pigments, the functions and mechanisms of action of which are poorly understood. In animals, they fall into two classes: phaeomelanins, red and orange pigments, and eumelanins, brown and black pigments. Melanins are complex polymers derived from DOPA, or, in the case of phaeomelanins, from DOPA and cysteine. The only enzyme necessary for their synthesis is tyrosinase, although in natural situations, at least one other enzymatic step appears to be involved. In pigment cells - melanocytes - melanins are synthesized in subcellular melanosomes. These tend to cluster around the cell nucleus. In dark skin, the melanosomes are ellipsoid, single and densely packed with pigment. In pale skin, they are round, aggregated and lightly pigmented. Melanocytes reside in the suprabasal layer of the epidermis. They derive from the neural crest and have dendritic processes that extend in amongst the keratinocytes. Immature melanosomes migrate into the dendrites and are phagocytized by the keratinocytes. Melanin synthesis is completed in the keratinocytes. As these cells mature, they migrate to the surface - as they continue to divide - where they extrude their nuclei and give rise to the stratum corneum which is made up mainly of keratin. Melanin is lost in the form of melanin dust. The gradient of melanin in the epidermis is least at the surface and greatest in the deeper layers - an odd arrangement for an umbrella.

Individuals with dark skin rarely get skin cancer, For many years, the dogma that melanin acts as a sunscreen has been accepted with little question. However, a number of recent studies indicate that melanin is a poor sereen and that tanning does not provide good sunlight protection. Furthermore, melanin pigments have been shown to be very reactive on illumination. They take up oxygen and produce active oxygen species, including hydroxyl radical. At rest, melanins have a standing free, radical signal. This is augmented upon illumination. Oxygen uptake and emission of active oxygen species are absorption spectrum dependent. The quantum yield is greater at wave lengths below $300 \mathrm{~nm}$. Melanins can transduce one form of energy into another. They can convert light energy into electrical energy and into heat. Melanins are important in the inner ear; albinos frequently suffer from hearing loss. Melanins are thought to be important in the modulation of sound energy. They bind to many drugs - with both beneficial and deleterious effects. Deafness induced by some antibiotics is probably caused by binding of the drugs to melanin in the ear. Melanins are important in the brain and the nervous system: Parkinson's disease is associated with loss of melanin in the substantia nigra.

Melanin pigments are difficult to study. Eumelanins, when extracted from tissues, are amorphous and insoluble. They must be oxidized to be solubilized. However, they do retain their free radical signal. Phaeomelanins are more soluble. They also tend to be more reactive. Individuals with red hair and freckles are the most skin cancer-prone probably because of the more reactive nature of the phaeomelanins, which are thought to be the pigment in freckles. 


\section{Helene z. Hill/Pagez}

Melanins appear to be two edged swords - on the one hand, protecting, on the other, enhancing solar and other types of damage. In the 1970's J. McGinness and P. Proctor advanced the theory that melanins are energy transducers: they can absorb many different kinds of energy and convert them to heat. However, if the energy input is too strong, the protective nature of melanins is overwhelmed and the input energy is transformed to free radicals and active oxygen species.

Our studies have been primarily with clonally related Cloudman S91 mouse melanoma cell lines that differ in their constitutive melanin levels and in their inducibility to produce high levels of melanin. We have studied DNA damage and its repair in these cells. We find that intracellular melanin appears to protect DNA to some extent from direct effect (UV-endonuclease sensitive sites) damage in the UVC but not in the UVB. It apparently quenches DNA-protein crosslink induction by UVA. But it also appears to photosensitize UVC induction of oxidative base damage (thymine glycols) in DNA. This damage is greatest in cells with more melanin and is unmeasurable at these same doses in cells that lack tyrosinase. Cells with more constitutive melanin are more sensitive to killing by UVB. Induction of melanin synthesis in facultative cells radiosensitizes DNA double strand breaks, enhances ionizing radiation billing and markedly enhances mutation induction by ethylmethane sulfonate. Induction of melanin synthesis parallels induction of thioredoxin reductase, a modulator of cellular free radicals.

Melanoma cells from a variety of sources have rates of post-replication repair that are higher than those found in non-melanoma and in normal cells.

These results suggest that melanins in vivo are, indeed, two edged swords. They can both protect against and potentiate genomic damage. The findings car. be reconciled with the fact of markedly reduced skin cancer in dark-skinned people: the ellipsoidal, densely melanotic melanosomes in dark skin would make a good screen and free-radicals that are produced in the melanin itself would be self-absorbed. In light skin, the aggregated melanosomes would allow for the uninterrupted passage of some photons to the nucleus, and free radicals would be freely emitted from the loosely packed melanosomal pigment. Tanning (melanin synthesis) appears to exacerbate genomic damage. Elevated rates of post-replication repair (i.e. DNA replication that is more proficient opposite damaged templates) may be the result of compensation for continuous oxygen stress imposed on the nucleus in cells that contain melanin and its precursors.

In the light of these findings, depletion of the protective ozone should be of even greater concern: melanins produce active oxygen species more efficiently at lower wave lengths. The destabilizing effect of melanin synthesis on mutation suggests that melanoma - the rate of which is doubling every ten years - may result not only from sunlight but from interactions of melanins with environmental xenobiotics, which are also on the increase. 
ONCOGENE ACTIVATION IN ULTRAVIOLET-INDUCED SKIN

TUMORS FROM NORMAL INDIVIDUALS AND XERODERMA

PIGMENTOSUM PATIENTS AND IN A CARCINOGEN-

TRANSFORMED XERODERMA PIGMENTOSUM CELL LINE.

A. SARASIN, L. DAYA-GROSJEAN, C. ROBERT-KNEBELMANN, C. DROUGARD, F. SUREAU and H.G. SUAREZ, Laboratory of Molecular Genetics, Institut de Recherches Scientifiques sur le Cancer, B.P. $n^{\circ} 894801$ - VILLEJUIF (France).

Patients suffering from the highly cancer-prone disorder, xeroderma pigmentosum (XP), are known to have a molecular defect in their ability to repair ultraviolet-light (UV) damaged cellular DNA, confirming thus the link between DNA lesions and cancer. We wanted to confirm that UV is the principal factor involved with the induction of skin cancers in humans by looking at the spectrum of mutations found in activated oncogenes from both XP and normal individuals.

We have shown the presence of activated ras oncogenes (N-ras, Ha-ra and Ki-ras) due to point mutations within specific codons together with modifications of other oncogenes (amplification and/or rearrangement) in XP skin tumors. The types of mutations observed on ras oncogenes in XP tumors can be explained by the presence of nonrepaired Py-Py DNA lesions. Similarly, the high level of Ha-ras amplification observed in XP. tumors may also be attributed to unrepaired lesions. Activated oncogenes are known to play an important role in the process of human malignancy and therefore it was interesting to compare ras gene mutations in skin tumors of normal individuals with those from XP patients. DNA from basal and squamous cell carcinomas from both types of patients were amplified using the polymerase chain reaction and ras mutations detected by differential hybridisation. All the ras codons were analysed, and the results showed that while $22 \%$ of skin carcinomas from the normal population had point mutations, more than $50 \%$ of XP tumors harbored point mutated ras genes. This significantly different level of ras mutation confirms the importance of unrepaired lesions in XP DNA which result in point mutations and play a significant role in tumor induction.

To reproduce an in vitro model for XP carcinogenesis, we have transformed diploid XP fibroblast cells, group C, (XP 4VI) with a recombinant $y$-myb plasmid. Transformed foci were isolated which showed tumorigenic properties and expressed the $45^{-} \mathrm{KDa} \mathrm{v}$-myb protein. In these cells, the Ha-ras was overexpressed as it is in XP tumors. Selection for flat revertants allowed us to isolate XP cells with a quasi-normal phenotype due to the loss of the $v$-myb gene. These cells were subsequently treated with MNNG which gave rise to transformed foci. High molecular weight DNA from these transformed cells was able to transform NIH3T3 cells due to the activation of the met oncogene in XP cells by MNNG. This is the second report of met activation by MNNG in human cells and the first in XP cells. 


\title{
Cellular Responses to Environmental DNA Damage
}

\author{
Poster Session A
}

Tuesday, December 2, 1991 4:30 p.m. - 6:30 p.m.

DNA Repair Enzymology (including cell extracts)

Specific Lesions and Techniques Sequence Specific Repair and Replication Inducible Responses/Ceil Cycle
POSTERS $1-27$

POSTERS 28-40

POSTERS 41.62

POSTERS 63-74 


\section{Cellular Responses to Envirumental DNA Damage}

A Xenopus Nuclear Extract that efficiently repairs UV-damaged-DNA

- Tim M. Jenkins, J.K. Saxena and Eric J.Ackerman, NIDDK, National Institutes of Health, Bldg. 10, Rm 9D15, Bethesda, MD 20892

We describe a nuclear extract derived from Xenopus oocytes that efficiently repairs UV-irradiated plasmid or oligonucleotides. The DNA repair reactions in the extract appear similar to those we previously reported in injected Xenopus cocytes [Saxena, et al., 1990 Nucl. Acids Res. 18, 7425]. The extract therefore appears to accurately reflect repair events that occur in living cells.

Surprisingly, there is very little DNA synthesis in the extract that is not related to DNA repair. DNA repair is aphidicolin sensitive and appears to require DNA polymerase $\alpha$ (and/or $\delta$ ). We have examined the role of several DNA polymerases and accessory proteins in the repair reaction as well as the the repair patch size. Repair substrates were either uniformly labeled or labeled as a consequence of repair synthesis by incorporating radioactive nucleotides. 
Cellular Responses to Environmental DNA Damage

The Role of Tryptophan 128 in T4 Endonuclease V.DNA Interactions. Katherine A. Atkins, Joseph M. Beechem ${ }^{\dagger}$, and R. Stephen Lloyd, ${ }^{\dagger}$ Vanderbilt University Center in Molecular Toxicology, tDepartment of Biochemistry and $\neq$ Depariment of Molecular Physiology and Biophysics, Nashville, TN 37232-0146.

T4 endonuclease $V$ is a $16 \mathrm{kD}$ DNA repair enzyme that incises DNA at the site of ultraviolet (UV) light induced pyrimidine dimers. Studies of the enzyme have demonstrated four sequential activities that lead to DNA strand cleavage: salt-dependent linear diffusion along non-target double-stranded DNA, pyrimidine dimer-specific binding, pyrimidine dimer-DNA glycosylase activity, and apurinic/apyrimidinic (AP) lyase activity.

Previous work has implicated the C-terminal portion of endonuclease $\mathrm{V}$ in dimer-specific binding. For instance, mutations at Lys130, Tyr129, and Tyr131 yielded enzyme with lowered dimer-specific binding. When endonuclease $V$ is associated with DNA, the tryptophan at residue 128 is hypothesized to be in close proximity to, if not directly intercalated between, the DNA bases. Since Trp128 is the only tryptophan present in endonuclease V, we have used both steady-state and time-resolved fluorescence measurements of this residue to follow the binding of the enzyme to DNA. The steady-state fluorescence was found to be significantly quenched upon addition of double-stranded DNA to endonuclease V. The fluorescence lifetime comprising the great majority of the fluorescence intensity also decreased from $4.16 \mathrm{nsec}$ to $3.3 \mathrm{nsec}$ upon DNA binding. The steadystate quench and lifetime change were used to measure the binding of endonuclease $V$ to a double-stranded 20 base pair oligonucleotide. The stoichiometry of the binding profiles found by these two techniques demonstrated that endonuclease $V$ binds to DNA as a dimer.

The biological relevance of Trp128 is being investigated by oligonucleotidesite directed mutagenesis. In past studies, when an amber mutation at position 128 was suppressed with the incorporation of a serine residue, the resulting mutant enzyme had wild type DNA binding and normal glycosylic bond scission activity but was incapable of making the AP bond scission. We have made four mutations in the den $V$ gene at the 128 position including the conservative change to tyrosine, and the more drastic changes to isoleucine, valine, and glycine. These mutants have been subcloned in an expression vector and expressed in uvrA - recA- $E$. coli. All mutant enzymes accumulate in $E$. coli at levels similar to that of the wild type enzyme as detected by Western blot analyses. Initial results demonstrate that UV survivals of these repair deficient cells are complemented to levels that are approximately equal to that observed with wild type endonuclease V. These four mutants are being purified and characterized as to their glycosylic bond scission and AP lyase activities. 
Cellular Responses to environmental DNA Damage

Mechanism of specific adduct recognition by Uvr ABC Excinuclease.

Elisabeth C. Bertrand-Burgeraf, Robert R.P.P. Fuchs.

Groupe de Cancérogenése et de Mutagenèse moléculaire et structurale, IBMC

15, rue R. Descaries, STRASBOURG, FRANCE.

(A)BC excinuclease results from the joint actions of UvrA, UvrB and UvrC proteins of E. coli. This enzyme removes from the DNA many types of adducts of dissimilar structures with different efficiencies. To understand the mechanism of substrate recognition and the basis of enzyme specificity, it is essential to investigate the efficiency of (A)BC excinuclease with different monomodified oligonucleotides ( $138 \mathrm{mer}$ ) containing different adducts in a similar non-specific sequence context.

On one hand it is important to test the relative efficiency of recognition of different types of adducts (E. Bertrand- Burggraf, J. Mol. Biol. (1991) 219, 27-36) on the other hand one has to test the effect of the local DNA structure on the efficiency of recognition of a given àdduct.

In this work we have essentially tested the effect of the local DNA structure on the different steps of $(A) B C$ excinuclease interaction with three AAF- monomodified 138 mers.

AAF (1 to 3)-DNA S'...AGTATCAC̣C G $G_{1}$ C G $_{3}$ CCACACGAGCTGAG...3'

(138 bp)

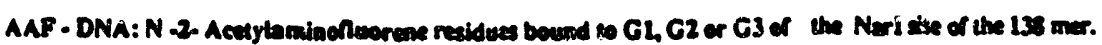

The differer is steps of the interaction were investigated successively by

DNAse I footprinting, incision assays and band shift experiments.

As described previously (E. Seeberg and R. Fuchs, PNAS (1990) 87, 191-194) the footprints observed for AAF(1) -DNA and AAF(3) - DNA are very similar, but the efficiencies of incision are different in absence of non-specific DNA (70\% for AAF(1)-DNA and $40 \%$ for AAF(3)-DNA). On the opposite, in presence of non-specific DNA both substrates are incised with the same efficiency (70\%). From our results, these observations can be explained by a difference in the rate of dissociation of UvrA from the preincision complex (E. Bertrand-Burggraf et al, J. Mol. Biol. (1991) 219, 27-36).

In the case of AAF(2)-DNA, the observed footprints are still better defined then those observed for the two previous oligomers (due in part to the fact that all the DNA is complexed); the efficiency of incision is nevertheless very low (15\%). We have shown that this last result can be explained by a high non-specific affinity of UvrA for this substrate, inhibiting the formation of specific UvrA-UvrB-DNA complexes.

In agreement with previous observations, these results indicate that substrate discrimination occurs essentially at the preincision step. 
Cellular responses to environmantal DNA damage

Replication of ultraviolet light-damaged DNA in vitro. H. P. Carty, S. El-Salah and $\mathrm{K}$. Dixon, Department of Environmental Health, University of Cincinnati Medical Center, Cincinnati, OH 45267-0056.

Environmental agents such as ultraviolet (UV) light which cause direct damage to DNA are important causes of cancers and genetic abnormalities in mammalian gystems. We are investigating the mechanism by which ultraviolet light induced lesions in DNA (thymine cyclobutane: dimers and 6-4 pyrimidine-pyrimidone photoproducts) are converted to mutations. Uv light has been shown to be mutagenic in vivo both in repair proficient and repair deficient mammalian cells, suggesting that replication of damaged DNA can be mutagenic. Purified mammalian cell polymerase $\alpha$ (one of the main cellular replicative polymerases) is arrested at the sites of UV-photoproducts when copying DNA templates in vitro. To investigate the mechanisms by which replication of damared DNA occurs, we have used soluble extracts from human (HeLa) cells which are capable of replicating shuttle vector plasmid DNA (pZ189), when supplemented with simian virus 40 , large $T$ antigen. Replication of plasmid DNA is inhibited in a dose-dependent manner by irradiation of the plasmid DNA prior to incubation in the extract, as determined by incorporation of radioactively labelled deoxyribonucleotide precursors into trichloroacetic-precipitable material, and by agarose gel electrophoresis of the product DNA. BY transformation of E. coli strain MBM7070 with the products of in vitre replication, we have obtained preliminary evidence for an increased mutation frequency in the supF mutagenesis target gene of p2189, suggesting that mutation fixation occurs during DNA replication in this system. The mechanisms, and the mutagenic consequences, of transiesion synthesis during DNA replication by DNA polymerases are being investigated using this in vitro system. 
Cellular Responses to Environmental DNA Damage

Inhibition of Topoisomerase II by Ultraviolet-Induced Cyclobutane Pyrimidine Dimers. Anita H. Corbett, E. Lynn Zechiedrich*, R. Stephen Lloyd, and Neil Osheroff. Department of Eiochemistry, Vanderbilt University School of Medicine, Nashville, TN 37232-0146 and "Department of Molecular and Cell Biology, University of California, Berkeley, CA 94720.

Topoisomerase II influences virtually every aspect of eukaryotic DNA metabolism. This enzyme is essential for cell viability and is required for chromosome segregation, structure, and condensation. In addition, it is involved in DNA replication and recombination. Finally, a role for topoisomerase II in DNA repair has been proposed. While a number of studies have investigated potential roles for topoisomerase II in DNA repair, none have examined the consequences of unrepaired DNA damage on topoisomerase II activity.

High levels of DNA damage are caused by the exposure of cells to short wave ultraviolet (UV) radiation. Pyrimidine dimers are the most prevalent photoproducts induced by such a treatment. The presence of dimers and other DNA lesions impairs replication and transcription and in some cases correlates with the formation of human cancers. Due to the prevalence of UV-induced photoproducts, the effects of these DNA lesions on the activity of eukaryotic topoisomerase II were investigated. Results indicate that these DNA photoproducts impair the enzyme's ability to relax negatively supercoiled PBR322 molecules. As determined by DNA photolyase photoreactivation experiments, enzyme inhibition was due to the presence of cyclobutane pyrimidine dimers in the DNA. When 10 to 20 cyclobutane dimers were present per plasmid, the initial velocity of topoisomerase IIcatalyzed DNA relaxation was inhibited $-50 \%$. In order to determine the mechanism by which cyclobutane dimers decrease the enzyme's activity, the effects of these lesions on individual steps of the topoisomerase II catalytic cycle were examined. While DNA binding and cleavage/religation (in the absence or presence of antineoplastic agents) were unaffected, the enzyme's DNA strand passage event (as monitored by a non-turnover DNA catenation assay) was inhibited. Furthermore, decreased rates of strand passage correlated with dimer-induced inhibition of overall catalytic activity. It is therefore concluded that cyclobutane dimers inhibit the DNA relaxation activity of topoisomerase II by impairing the enzyme's ability to mediate its strand passage event. These results demonstrate that the repair of cyclobutane pyrimidine dimers is important for the efficient cataiytic function of eukaryotic topoisomerase II.

Supported by NIH grants GM-33944, CA-09582, ES-04091, ES-00267, and ACS Facult; Research Awards FRA-370 and FRA-381. 
Cellular Responses to Environmental DNA Damage

Excision Repair of Uracil Residues in DNA By Mammalian and Escherichia coli Cell Extracts.

Grigory Dianoy and Tomas Lindahl

Imperial Cancer Research Fund, Clare Hall Laboratories, South Mimms, Potters Bar, Herts, EN6 3LD, U.K.

A double-stranded oligonucleotide containing a single uracil residue at a defined position was used in an in vitro DNA repair assay to estimate the size of the repair patch. The uracil-containing oligonucleotide was efficiently repaired in gently prepared cell-free extracts of E. coli NH5033 (recB', sbcB', endA') or human lymphoblastoid cells. Restriction enzyme analysis of the repaired oligonucleotide has shown that about $70 \%$ of the labelled dNTP was incorporated at the position of the removed uracil residue with $20 \%$ incorporation at the position of the next 3 'nucleotide and $10 \%$ at the following $3^{\prime}$ residues. No significant incorporation was observed on the $5^{\circ}$ side of the lesion. These results show that during the repair of uracil residues in DNA in a cell-free system only a one $(70 \%)$ or two $(20 \%)$ nucleotide gap is produced by repair enzymes and refilled by DNA polymerase. 
An Enzymatic Activity Isolated From Brassica oleracea Which Recognizes Cytosine Photoproducts in Uttraviolet Irradiated DNA. Patricia E, Gallagher, John R. Lenhart, and Randi B. Weiss. West Virginia University, Department of Biology, Morgantown, W 26506.

In recent years, a marked depletion of stratospheric uzone has caused an increase in ultraviolet radiation reaching the surface of the Earth. With this increase, concem and interest has been raised as to what specific effects ultraviolet radiation has on cellular processes in organisms. One such effect, the damage of DNA, has been extensively investigaied in bacterial and mammalian systems; however, limited information exists on the effects of ultraviolet radiation damage to plant DNA and its in vivo repair by cellular mechanisms. Here we describe the initial study of an enzymatic activity partially purified from plant tissue that recognizes and incises ultraviolet irradiated DNA at sites of ring-saturated pyrimidines. The enzymatic activity was detected in the leaf tissue of Brassica oleracea (cauliflower) using a nitrocellulose filter-binding assay. This assay measures the formation of enzyme-generated single strand breaks in the ultraviolet-irradiated, radiolabeled, viral DNA substrate. The enzyme was partially purified by diethylaminoethyl cellulose and phosphocellulose ion-exchange chromatography followed by affinity chromatography using heparinagarose. Characterization of the most purified fractions has shown that the optimal temperature for maximal enzyme activity is $470 \mathrm{C}$ with a pH optimum between 7.0 and 7.5. In addition, the endonuclease is active in both Tris and phosphate buffers, although it is stimulated by phosphate concentrations up to $25 \mathrm{mM}$.

The nature of the DNA damage recognized by the plant endonuclease was investigated using a DNA sequencing assay. An ultraviolet irradiated, 3'-end-labeled, defined DNA sequence was incubated with the partially purified plant enzyme; the reaction products were separated by polyacrylamide gel electrophoresis and compared to Maxam and Gilbert chemical cleavage fragments. Analysis of the resultant audioradiogram showed that all sites of endonucleolytic incision by the plant enzyme occurred at sites of cytosines in the ultraviolet irradiated substrate. No enzyme-induced cleavage of undamaged DNA was observed. The cytosine incisions were found in regions of the DNA sequence lacking adjacent pyrimidines and therefore are neither cyclobutane pyrimidine dimers nor 6-4-(pyrimidin-2one)pyrimidines. Incision at cytosine photoproducts was not detected at loci corresponding to alkali-labile sites in either control or irradiated substrates. This demonstrates that the sites of enzymatic incision were not the result of DNA strand breaks, base loss sites, or ring-opened pyrimidines.

Currently, a release assay using the synthetic polymer poly(dG-dC)poly(dG-dC) radiolabeled by nick translation with $[5,3 \mathrm{H}]$-dCTP is being used to determine the precise mechanism of action of this enzyme. In addition, the action of this endonuclease against DNA and synthetic polynucleotides treated with chemical oxidizing agents is being investigated to determine if this endonuclease is the plant counterpart to $E$. coli endonuclease III and the human redoxyendonuclease, the bacterial and mammalian enzymes that initate the repair of ring-saturated pyrimidines. (Supported by NSF Grant DMB-9005762). 


\section{CELLULAR RESPONSES TO ENVIRONMENTAL DNA DAMAGE}

PROCESSING OF UV-INDUCED DNA DAMAGE IN CULTURED HUMAN FIBROBLASTS. Anne M. Galloway Michel Liuzzi, John R. Chan, and Malcolm C. Faterson, Cross Cancer Institute, Edmonton, Alberta T6G 172, Canada.

A novel nuclease digestion/HPLC method has heen developed (j) to elucidate the excision-repair system(s) operative in cultured human skin cells on cyclobutyl pyrimidine dimers and 6-4'-(pyrimidin-2'one)-pyrimidine photoproducts [(6-4) photoproducts]); and (ii) to purify and characterize a putative human repair enzyme termed intracyclobutyl pyrimidine dimer-DNA phosphodiesterase (IDP) which hydrolyzes the internal phosphodiester linkage between dimerized pyrimidines. The procedure entails: (i) isolation of $[\mathrm{H}$ ] thymidine-labelled excision fragments from post-UV (40 J/m², 254-nm light)-incubated human cells; (ii) formic acid hydrolysis, (iii) digestion with snake venom phosphodiesterase, nuclease $P 1$, and calf alkaline phosphatase; and (iv) hot alkali treatment of enzymatically digested oligonucleotides. This method has demonstrated that the excision kinetics for the two classes of UV photoproducts under study differ greatly in normal cells. (6-4) photoproducts are removed in their entirety by $6 \mathrm{hr}$ post UV, whereas fyclobutyl dimers are processed much more slowly, with a retention halflife of $\sim 16 \mathrm{hr}$. Interestingly, the vast majority $(-85 \%)$ of the excised dimers contain a cleaved interpyrimidine phosphodiester bond, an observation consistent with our other findings pointing to the existence of a pre-incision, intraciinsor backbone-cleavage step in the removal of this class of photoproducts. By contrast, (6-4) photoproducts are reiessed with the internal phosphodiester linkage intact. Moreover, the nuclease digestion/HPLC mithod has revealed that fibroblast strains representing xeroderma pigmentosum $(X P)$ complementation groups $A, C, D, E$ and $F$ all exhibit at least a partial deficiency in the repair of cyclobutyl dimers and/or (6-4) photoproducts which is unique for each complementation group, implying that mutations at different loci underlie the various genetic forms of the disease XP group A cells, for example, are totally defective in the repair of both photolesions. XP group D cells, while unable to excise cyclobutyl dimers, retain $\sim 40 \%$ of normal proficiency at removing $(6-4)$ photoproducts. This partial repair fully accounts for the previously unexplained unscheduled DNA synthesis in these cells. Conversely, XP group F cells exhibit normal kinetics for dimer excision but are completely inept in (6-4) photoproduct removal. XP group C cells are partially defective in the removal of both photolesions, and although these cells display $40 \%$ of normal (6-4) photoproduct repair by 24 hr post UV, the kinetics differ markedly from that observed in XP group D cells. Finally, XP group E cells are normal for cyclobutyl dimer removal and act on all (6-4) photoproducts, but at a considerably reduced rate.

A variety of human specimens (i.e., lymphocytes, liver tissue and cultured fibroblasta) have been found to contain an activity capable of mediating the intradimer backbone-nicking reaction; this so-called IDP activity, which is optimally expressed at pH 5.0 and is associated with a $\mathrm{Mg}^{+t}$-activated, $53 \mathrm{kD}$ protein, has now been purified 3500-fold from human liver in a four-stage procedure employing affinity (Con-A Sepharose), ion exchange (Accell CM and QMA), and gel filtration (Sephadex G100) chromatographies. Cultured cells from patients with XP groups A-G and the variant, as well as Cockayne syndrome, all contain at least normal levels of IDP activity, suggesting that the UV hypersensitivity of these different strains does not result from a defect in IDP. (Sponsored by Medical Research Council of Canada and Alberta Heritage Foundation for Medical Research) 
Structure - function dynamics in the Escherichia coli uvrB protein. Eric $L_{\text {. Hildebrand and }}$ Lawrence Grossman, Department of Biochemistry, School of Hygiene and Public Health, The Johns Hopkins University, Baltimore, Maryland.

The uvrB gene product is one of three proteins required for double endonucleolytic incisions flanking DNA damage sites in Escherichiz coli. Its role in the repair process has become more clear with recent revelations regarding expression of a cryptic ATPase activity - absent it the purified native protein but turned on by interaction with the uvrA protein and single-stranded DNA. It is most likely that ATP hydrolysis by the uvrB moiety drives translocation of the uvrA-uvrBprotein complex along the DNA helix to a site of damage (Seeley and Grossman, J. Biol. Chem. 265:7158 1990).

Long-term objectives of ine present study are to elucidate the mechanism by which the cryptic ATPase activity of uvrB is activated, and thereby to provide a means to follow the dynamics of uvrA - uvrB - DNA interaction. Fluorescence techniques, both steady-state and time-resolved, are especially appropriate for such structure-function studies. Fortuituosly, the uvr B protein has no tryptophan residues, although 24 tyrosines are present.

Using cassette mutagenesis, three 'mutants' of uvrB were constructed, each introducing a single tryptophan residue in the vicinity of the ATPase sequence motif. Two of the constructs (F47W, a phenylalanine to typtophan substitution at residue 47, two residues away from an essential lysine, K45; and the asparagine to tryptophan mutant, N51W) have been shown to be phenotypically indistinguisable from the wild-type as judged by resistance to UV irradiatior. The 'mutant' proteins have been overexpressed in an $E$. coli host, and the uvrB F47W gene product purified. Chromatographic properties of the typtophan-bearing variant do not measurably differ from the behavior of wild-type protein during purification.

Earlier work in this laboratory has shown both that the ssDNA dependence of uvrB ATPase activation is non-specific - high salt concentrations (e.g. $5 \mathrm{M}$ succinate) may substitute for ssDNA, and that the ATPase activity is manifested in the larger of two proteolytic products, designated as uvrB*, in the absence of uvrA protein (Caron and Grossman, Nucleic Acids Res. 16:10891 1988). Proteolysis is believed to occur at a site approximately 43 residues from the $C$ terminus, releasing a hydrophobic fragment. For initial studies of structural changes in uvrB accompanying ATPase activation, the simpler model system consisting of purified uvrB* $+0.5 \mathrm{M}$ succinate (or denatured calf-thymus DNA) has been employed. Focusing on the intrinsic fluorescence of the introduced typtophan residue, conformational changes accompanying ATPase activation by proteolysis of uvrB F4TW can be demonstrated by steady state techniques. 
MODELIZATION OF INTERACTION IN A POLY(ADP-RIBOSE) TURNOVER SYSTEM Iean Laqueux ${ }^{1}$ Gino Brochu' ${ }^{1}$ Luc Ménard ${ }^{1}$ Erédéric Potvin' 1 Paul Cook ${ }^{2}$ Guy G. Poirier1. 1 Poly (ADP-ribose) Research Group, Molecular Endocrinology Laboratory, CHUL Research Center and Laval University, Québec, G1V 4G2, Canada and 2Department of Microbiology, Texas College of Osteopatic Medicine, Forth Worth, Texas, USA.

In DNA excision repair, poly(ADP-ribosyl)ation of different nuclear proteins occurs after postincisional by activation of poly(ADP-ribose) polymerase. Poly(ADP-ribose) is synthesized and degraded by poly(ADP-ribose) polymerase and glycohydrolase, respectively. We have reconstituted in oitro a turnover system containing these two enzymes in order to recreate a situation similar to the one that exists in vioo. We have measured the kinetics of NAD consumption, ADP-ribose production and polymer accumulation during turnover. The two enzymes used in the turnover system were purified to homogeneity, when in our previous report on the turnover system, only partially purified enzymes were used. A mathematical model was developed to describe the kinetics of polymer, nicotinamide and ADP-ribose accumulation in such a system. This poly(ADP-ribose) turnover can be considered as a coupled enzyme system in which the poly(ADP-ribose) polymerase product (poly(ADP-ribose)) serves as a substrate for the glycohydrolase. We will present the results of the interaction in a 1:1 activity ratio of the two enzymes with correction factors needed by the automodification activity of polymerase. This system will be used to study the poly(ADP-ribosyl)ation implication in DNA excision repair. 


\section{"Cellular Responses to Enviromental Da Damage"}

Mechanism of Damage Recognition on UVC Irradiated Dn and of Interaction with Bistones by a Buman Chromatin-Associated DN Endomuclease Complex and Abnormalities in this complex in XPA Cells. Muriel $\mathrm{F}$. Lambert, Sue Feng, Bo Bang and David Arbesfeld, Department of Laboratory Tedicine and Pathology. Uunis-New Jersey kedical School, Newark, N.J.

We have isolated a DN endomuclease complex, p] 7.6, from chromatin of normal muman Iyuphoblastoid cells which recognizes Di A damage produced by UVC irradiation, predominately pyrimidine dimers. Itris same complex is also present in ceils frcm patients with the UV sensitive, cancer prone, genetic disease, xeroderma pigmentosum, complementation group A (XPA), at levels of activity similar to those of normal cells. Since XPA cells are defective in the initial, endomuclease mediated step of the excision repair process, these studies indicate that the defect does not exist in the ability of the XPA complexes to incise damaged naked DN. We have shown that interaction of the normal endomclease complex with UVC irradiated nucleosomal DNA (t histone Bi) leads to an increase in endomuclease activity on this substrate. Using a well characterized reconstituted mucleoscmal system, we have found that the core histones, H3 and B4, are major contributors to this increased endomuclease activity. The XPA endomelease complex, in marked contrast, is defective in Its ability to interact with UVC damaged mucleoscmal DNA and shows decreased activity when histone $\mathrm{mI}$ is present. Kinetic analysis indicates that the normal complex has an increased affinity or rate of association for UVC irradiated core (histones B2A, B2B, H3, B4,) and total (core \pm histone BI) mucleoscmal DNA. The XPA complex, on the other hand, shows rectuced affinity or rate of association for UVC irradiated DNA, particularly when histone ml is present. These studies indicate that the normal complex contains both an endomuclease and a protein needed for interaction with chromatin and that this protein is defective in XPA cells.

The normal and XPA endomuclease complexes have been analyzed for their ability to influence binding of histones to DNA. Utilizing our reconstituted meleosomal system, consisting of [B] plasmid DNA and normal hman histones, and a Eilter binding assay, we have found that the normal Inman endonuclease complex, pI 7.6, decreases binding of histones to $\mathrm{DN}$ in a dose dependent manner. The XPA endomuclease complex, in contrast, has only a slight ability to decrease histone binding to DN. Ithis effect on histone binding is independent of whether the DNA is UVC irradiated or not.

The mechanism by which these endomuclease complexes locate sites of UVC damage on DN has also been examined. Studies have been carried out to determine whether these complexes locate their target sites by a one-dimensional diffusion or sliding process (processive mechanism) or by a three dimensional random search process (distributive mechanism). The present investigation shows that the notmal endonuclease complex locates sites of damage in a processive manner. The XPA complex, however, interacts with UVC damaged DN by a distributive mechanism. This difference in mode of damage recognition could be wre to the endomuclease itself, and thus represent a second defect in the XPA repair complex. On the other hand, it could be due to the association of the endonuclease with the protein needed for interaction of the endomclease with chromatin. Since this protein is defective in XPA cells, It could be contributing to a distributive rather then a processive mode of damage recognition by the XPA endomuclease. 
REI'AIR OY IMIDAZOLE RING-OI'ENED FUKINES AND 8-HYUROXYGUANINE BY ESCHERICHIA COII FPG PROTE.IN AND MAMMALIAN ENZYML:.

Jacques Laval, Timothy R. O'Connor and Serge Boiteux. "Groupe Réparation des Lesions Radio et Chimioinduites"U140 INSERH, UAI 47 CNRS, Institut Gustave Roussy.94805 Villejuif, France.

The FPG protein of Eccoll was initially identified as a DNA glycosylase which excises the imidazole ring-opened form of N7-Methylguanine residues in DNA. The structural gene, fog. coding for the FPG protein of Ecoul was cloned and sequenced. The FPG protein was purified to homogeneity and ldentified as a 30 kVa protein. The FHG protein is a metajloprotein containing one zinc atom per monomer. This zinc is most likely included in a "zinc finger". Non conservative sjte directed mutants in the four cysteine residues of the $\mathrm{an}$ finger consensus sequence of the FrG protein have approximately 1000-101d lower Fapy DNA glycosylase activity. The FPG protein possesses:an AP nicking activity which incises the DNA both at the $3^{\prime}$ and $5^{\prime}$ side of the abasic site leaving a gap ilmited by two phosphate groups. Xinetic constants of the excision of the deoxyribose derjvative for the various mutated proteins will be presented.

The PPG protein excises imidazole ring-opened nurines modified at the $N 7$ position by small or bulky alkylating agents or at $C 8$ position by the carcinogen N-hydroxy-2-aminof luorene. We have demonstrated that DNA modified by Methylene Blue plus visible light (MB/light) is inclsed by FPG protein. The FPG protein rejeases 8-hydroxyguanine resldues from MB/light treated DNA using HPIC with electrochemical detection as analysis method. These results show that the FPG protejn has a broad substrute specificity including imidazole ring opened purines and also 8-hydroxyguanine.

We have purified more than 5000, times from calf thymus extracts, an enzymatic activity recognising both fapy residues and 8- hydroxyguanine. Evidence for a single protein carrying the two enzymatic actjujties will be presented.

The FPG protein should be considered as a major DNA repair enzyme which protects DNA from the deleterious effects of alkylating agents as well as those of reactive oxygen specles. The presence of a repair activity related to the FPG protein was identified and partially purjejed from mammalian cells. 


\section{CELLULAR RESPONSES TO ENVIRONMENTAL DNA DAMAGE}

Purification and Biochemical Characterization of a Binding Protein Activated by Ionizing Radiation.

Martin F. Lavin, Kum Kum Khanna, Duygu F. Findik and Brett Teale.

Queensland Cancer Fund Research Unit, Queensland Institute of Medical Research, The Bancroft Centre, P.O. Royal Brisbane Hospital, Brisbane, Australia 4029.

A recent report from this laboratory described a novel DNA binding protein recognising the specific sequence TGTCAGTTAGGGT which was activated by ACAGTCAATCCCA

gamma radiation in human lymphoblastoid cells (1). Here we describe the purification of this protein/factor from human placenta.

The purification scheme consists uf chromatography of soluble whole cell extract on DEAE Sepharose CL-6B, heparin agarose, and three successive DNA affinity columns. The DNA affinity matrix was prepared by coupling ligated complementary synthetic oligonucleotides containing the recognition sequence to CNBr activated sepharose CL-4B (2). The DNA binding activity was monitored throughout the purification by gel mobility shift assay using end-labelled synthetic oligodeoxynucleotides. The purified preparation consists of three major polypeptides with molecular weights of $70 \mathrm{kDa}, 47 \mathrm{kDa}, 31 \mathrm{kDa}$ bound specifically to the recognition sequence as determined by UV crosslinking and south western blotting. The sequence of these proteins is being determined and subsequently cDNA clones will be isolated. It is expected that this information will be useful in understanding the defect in the human genetic disorder ataxia-telangiectasia (A-T) since we have observed that the binding protein is present constitutively in nuclei from these cells. The protein is not present in nuclei from unirradiated control cells but after $\gamma$-radiation exposure appears to be translocated from the cytoplasm.

\section{References}

[1] S.P. Singh and M.F. Lavin (1990), Mol. Cell. Biol. 10, 5279-5285.

[2] J.T. Kadonaga and R. Tijan (1986), Proc. Natl. Acad. Sci. USA 83, 58895893. 
Reconstituted System of Base-Exciston Repair Derived from Xenopus laevis oocytes. Yoshihiro Matsumoto and Daniel F. Bogenhagen, Department of Pharmacological Sciences, State University of New York at Stony Brook, Stony Brook, New York 11794, USA.

The 3-hydroxy-2-hydroxymethyl tetrahydrofuran residue is a synthetic analog of the sugar residue in the natural AP site which is a common intermediate product in base-excision repair. This synthetic abasic site in DNA is efficiently repaired by a short patch repair mechanism in soluble extracts of Xenopus laevis oocytes. In this reaction the DNA is cleaved within $15 \mathrm{sec}$ on the $5^{\prime}$ side of the lesion by a class II AP endonuclease. After cleavage, DNA synthesis precedes excision of the abasic residue and ligation. These subreactions proceed in a coordinated manner to complete repair (Matsumoto and Bogenhagen, Mol. Cell. Biol. 11:4441-4447, 1991). The reactiton is sensitive to aphidicol in but resistant to ddNTP and BuPdGTP. To identify the components involved in this repair, we fractionated the crude extract through column chromatography and reconstituted the reaction with those fractions. In this reconstituted system at least three components were required to complete repair. During fractionation the activity of abasic-site repair did not correlate to the activity of either DNA polymerase $\alpha, \beta$ or $\epsilon$. We present further characterization of those components. 


\section{"CELlular RESPONSES TO ENVIRONMENTAL DNA DAMAGE"}

INCREASED DNA DAMAGE RECOGNTTION PROTEINS iN CISPLATIN RESISTANT OVARIAN TUMOUR CELLS. K.Mclaughlin* \& R.Brown, CRC Dept. Medical Oncology, University of Glasgow, UK.

Cis-diamminedichloroplatinum (II) (CDDP) is a major chemotherapeutic drug used successfully in the treatment of various types of cancer. There is strong evidence that DNA is the drug's principle target for its antitumour activity. Although a number of different DNA adducts are formed, the major adduct is the intrastrand cross-link between the $\mathbf{N} 7$ positions of adjacent guanine residues. While the nature and relative frequency of CDDP induced DNA adducts have been elucidated, the relative contribution to cytotoxicity and the mechanisms responsible for the repair of these lesions remains poorly defined. Since the isomeric drug trans-DDP is not an antitumour agent and is unable to form intrastrand cross-links, this has led to the proposal that an intra-strand cross-link unique to the cis configuration may be the carcinotoxic lesion. Using South-Westem analyses we have identified three proteins which binds to doublestranded DNA which has been treated in vitro with CDDP. These proteins are shown to have approximate molecular masses of 25,50 , and $100 \mathrm{KD}$. They appear to be different from UV-damage recognition proteins, previously shown to be deficient in a xeroderma pigmentosum patient representing complementation group $\mathrm{E}$. The 50 and $100 \mathrm{KD}$ damage recognition proteins are increased in a CDDP resistant human ovarian tumour cell line. The substrate specificity of these proteins has also been examined.

* Currently at ICRF Dept. Medical Oncology, University of Edinburgh, UK. 
Cellular Responses to Environmental DNA Damage

Properties of the $3^{\prime}$ to $5^{\prime}$ Exonneleaseo Ascociated with Mitochondrial and Chloroplast DNA Polymerases.

Matthew J. Longley, Cynthia A. Keim and Dale W. Mosbaugh

Departments of Agricultural Chemistry; Biochemistry and Biophysics; and Environmental Health Sciences Center. Oregon State University, Corvallis, Oregon 97331.

Porcine liver mitochondrial DNA polymerase copuriffes with an associated $3^{\circ}$ to $5^{\circ}$ exomuclease activity which is characterized. The exomuclease activity excises $3^{\prime}$-terminally mismatched mucleotides with -5 -fold preference over matched $3^{\prime}$-termini. Decryribonucleotide $S^{\prime}$-monophosphate appears to be the exclusive hydrolysis product. The exonuclease has a 7.5-fold preference for single-stranded over double-stranded DNA, but $3^{\prime}$-terminal ddNMP residues were refractory to bydrolysis from either substrate. The binetics of $3^{\prime}$-terminal excision were measured at a single site on M13̈mp2 DNA for each of the sixteen possible matched and mismatched primer template combinations. Analysis of substrate specificity constants $(V \max / \mathrm{Km})$ indicated that each of the twelve mismatched primer termini were preferred over the four matched substrates $(A \cdot T, T \cdot A, C \cdot G, G \cdot C)$. Like the DNA polymerase activity, the exomuclease had an absolute requirement for a divalent metal cation ( $\mathrm{Mg}^{2+}$ or $\mathrm{Mn}^{2+}$ ), a relatively high $\mathrm{NaCl}$ and $\mathrm{KCl}$ optimum ( $-200 \mathrm{mM}$ ), and a broad alkaline pH optimum (pH 7-10). However, DNA polymerase and exonuclease activities exhibited dissimilar rates of heat inactivation and sensitivity to N-ethylmaleimide. Following nondenaturing activity gel electrophoresis, the DNA polymerase and $3^{\prime}$ to $5^{\prime}$ exonuclease activities were partially resolved and detected in sin as separate polypeptides. Using SDS-polyacrylamide activity gels, catalytic polypeptides were identified with molecular weights of 127,000,60,000 and 32,000 which possessed only DNA polymerase $r$ activity.

Spinach chloroplast DNA polymerase was also shown to copurify with a $3^{\prime}$ to $S^{\prime}$ exomuclease. Further oxore, both activities comigrated during nondenaturing polyacrylamide activity gel electrophoresis and cosedimented through a glycerol gradient with an apparent molecular weight of 105,000 . However, two forms of exonuclease activity were detected following velocity sedimentation analysis. Form I consisted of both exonuclease and DNA polymerase activities; whereas, form II was free of DNA polymerase and exhibited a molecular weight of $\sim 26,500$. Resedimentation of form I (DNA polymerase/exonuclease) generated both polymerase associated and unassociated forms of the exonuclease, suggesting that polymerase/exonuclease dissociation occurred. Both form I and II exonuclease shared similar properties and were shown by SDS-polyacrylamide activity gel electrophoresis to reside in a polypeptide of $\sim 20,000$ molecular weight. In contrast, form I DNA polymerase and exonuclease activities exhibited dissimilar sensitivity to N-ethylmaleimide. Like the $3^{\prime}$ to $5^{\prime}$ exonuclease associated with the mitochondrial DNA polymerase, the chloroplast $3^{\prime}$ to $5^{\prime}$ exonuclease preferred to hydrolyze mismatched $3^{\prime}$-terminal nucleotides and it resides on a polypeptide distinet from the polymerase. (Supported by NIH grants GM32823 and ESOO210) 


\section{Cellular Responses to Envirommental DNA Damage}

Cyclin-11ke Properties of Urac1l-DNA Glycosylase

susan $J$. Muller and Sal Caradonna

URDNJ-SOK

401 South Central Plaza

stratzord, NJ 08084

Urac1l-DNA glycosylase is an enzyme which functions in the removal of uracil from DNA. Our laboratory has previously isolated and characterized a human gene encoding uracil-DNA glycosylase. A search of genbank's protein database revealed homology to the cyclin family of proteins. The cyclin proteins appear to be involved in regulating check points throughout the cell cycle. While overall these proteins diverge significantly from one another, they share a highly conserved 150 amino acid region termed the "cyclin box". Uracil-DNA glycosylase shares $27 \%$ identity and $60 \%$ homology with the "cyciln box" of human cyclin A. A second highly conserved region is located near the amino terminus of most mitotic cyclins. This short "destruction box" sequence is believed to mediate cyclin protein degradation. No homology to these sequences is found in uracil-DNA glycosylase. However, labeling and immunoprecipitation studies indicate that uracil-DNA glycosylase protein turns over during one cell cycle.

Cyclins interact with cellular proteins to form high molecular weight complexes which are regulated in a stage specific manner. To investigate the possibility that uracil-DNA glycosylase may aseociate with cellular proteins, extracts prepared from asynchronous fibroblasts were analyzed by exclusion chromatography. Oracil-DNA glycosylase eluted as a high molecular weight complex of approximately $250 \mathrm{kD}$. Interestingly, this complex shifted to a much lower molecular weight (approximately $36 \mathrm{kD}$ ) when fibroblasts were arrested in $G_{0}$ by serum deprivation. This low molecular weight complex was also present in fibroblasts that were arrested in mitosis by nocodazole block.

Recently, Mudryj et al. (Mudryj, H., Devoto, S.H., Hiebert, S.W., Hunter, T., Pines, J., and Nevins, J.R. Cell 65:1243-1253, 1991) have shown that cyclin $A$ is involved in a protein complex with the E2F transcription factor. This association occurs during the s-phase in NIH3T3 cells. The association of $E 2 F$ and cyclin $A$ was not seen in HeLa cells. The Interpretation given for the absence of this complex is that HeLa cells contain DNA tumor virus derived transcription factors (1.e. human papilloma virus-18, 57 protein) which usurp E2F for alternate transcription functions. Intersetingly, we do not see uracil-DNA glycosylase associated with the $250 \mathrm{kD}$ complex in HeIa cells. We are currently examining uracil-DNA glycosylase complex formation and its relation to cyclins during other stages of the cell cycle. 
"Cellular responses to environmental damage"

CELLULAR SENSITIVITY OF UV RODENT CELLS TO CAMPTOTHECLN AND ITS RELATIONSHIP TO DNA TOPOISOMERASE I._A. Lanza, S. Tomaletti, H.H. Evans*, G.C.B. Astaldi Ricotti, M. Stefanini and A.M. Pedrini - Istituto di Genetica Biochimica ed Evoluzionistica del C.N.R., Pavia, Italy; *Department of Radiobiology, Case Western Reserve University, Cleveland, U.S.A.

Many evidences indicate that camptothecin (CPT) cytotoxicity depends from the stabilization of the "cleavable complex", which results in longerlived potentially cytotoxic strand-breaks. Since the cellular responses to CPT (DNA synthesis inhibition, reversible fragmentation of chromosomal DNA, G2 arrest, increased rate of sister chromatid exchanges and chromosomal aberrations) are also indicators of DNA damage, D'Arpa and Liu (1989) have proposed that CPT-induced strand-breaks might be viewed by the cell as a new type of DNA damage. To define better the relationship between CPT-induced damage and DNA repair processes, we have studied CPT sensitivity at the cellular and biochemical levels in mammalian cells selected for increased sensitivity to chemical and physical DNA damaging agents. First we have examined the protein level and catalytic activity of DNA topoisomerase I, the CPT sensitivity of the enzymatic activity and of the "cleavable complex" in two related strains of mouse lymphoma L5178Y (Evans et al., 1989). Strain Ly-S exhibits enhanced sensitivity toward ionizing radiation and to the cytotoxic effects of DNA topoisomerase II inhibitors (m-AMSA, ellipticine, VP-16), while the parental strain line $L y-R$ was more sensitive to $U V$ radiations and to CPT. In $L y-R$ we have observed a reduction of the catalytic activity and the protein level of DNA topoisomerase I to about $70 \%$ of the level measured in Ly-S. But, CPT lacked differential effect on relaxation activity, reaction kinetics, or stabilization of the "cleavable complex". Since these results tended to suggest that CPT hypersensitivity in $L y-R$ strain could be related to a defect in the responses to CPT induced damage rather than to a primary deficiency of DNA topoisomerase $I$, we extended our analysis to UV sensitive CHO cell lines belonging to different complementation groups. All the mutants analyzed so far showed a higher sensitivity toward CPT with respect to parental cells. Among them, the two revealing the highest level of CPT sensitivity were further characterized for DNA topoisomerase I properties. Also in these cell lines, biochemical analysis revealed no difference between mutants and parental cell lines. Also these results indicate that cells see CPT-induced "cleavable complex" as a form of .DNA damage and that the repair capability of the cell is an important factor in the response to CPT. Work supported by P.F. Ingegneria Genetica, CNR. 
Preparation of repair enzyme substrates containing an internucleotide pyrophosphate bond and their recognition by Escherichia coli uracil DNA-glycosylase.

Andref A. Rurma, Susan S. Wallace and Yoke W. Kow Department of Microbiology and Molecular Genetics, University of Vermont, Burlington, Vermont, 05405

Modified DNA duplexes containing unnatural internucleotide pyrophosphate bonds adjacent to uracil and abasic sites are useful compounds for the study of the mechanism of action and substrate specificity of repair enzymes. In this investigation we describe the prepapation of such modified substrates and the recognition of uracilcontaining modified substrates by E.coli uracil DNA-glycosylase. By the method of water soluble carbodiimide-induced chemical ligation, two $27-$ member DNA fragments containing a deoxyuridine and a pyrophosphate internucleotide bond were prepared. One oligonucleotide contained a pyrophosphate bond 5'- to the deoxyuridine residue:

5'- GGTCGACTppdUAGGAGGATCCCCGGGTAC -3' and the other a pyrophosphate bond $3^{\circ}$ - to the deoxyuridine residue:

5'- GGTCGACTdUP PAGGAGGATCCCCGGGTAC -3'

Surprisingly, both modified oligonucleotides were found to be poor substrates for $E$. coli uracil DNA-glycosylase. The removal of uracil from single stranded DNA fragments (I) and (II) proceeded about 100 times more slowly than in the case of unmodified uracil-containing DNA and excision did not reach completion even in substantial enzyme excess. Double stranded DNA molecules containing a pyrophosphate bond either 3'. or 5'- to the deoxyuridine residue in one strand, were prepared by annealing (I) or (II) with a complementary, but normal single-stranded oligonucleotide. In this case uracil removal proceeded quantitatively with the rate being about 10 times slower than with the unmodified substrate. DNA (I), with a pyrophosphate on the 5'- side, was found to be a better substrate for uracil glycosylase in both cases (single or double stranded) than DNA (ID).

We also showed that uracil glycosylase can remove uracil from a nicked double-stranded DNA duplex:

5' - GGTCGACTdUp AGGAGGATCCCCGGGTAC -3'

3' - ACGTCCAGCTGA-A-TCCTCCTAGGGGCC -5'

Removal did not occur in the absence of the 3'-phosphate of the uridine residue, suggesting its importance for uracil glycosylase recognition of the nicked substrate.

The reaction of uracil glycosylase with oligonucleotides containing deoxymridine adjacent to the internucleotide pyrophosphates was then used to prepare unnatural substrates containing abasic sites. 
Cellular Responses to Environmental DNA damage

Biological role of yeast Apnl AP endonuclease/3'-repair diesterase and functional substitution in yeast by $\underline{E}$. coli endonuclease IV. Dindial Ramotar and Bruce Demple, Havard School of Public Health, Department of Molecular and Cellular Toxicology, Boston, MA 02115, U.S.A.

The Apn1 protein of Saccharomyces cerevisiae functions in the repair of both oxidative and alkylation damages to cellular DNA by removing $3^{\prime}$-fragments of deoxyribose and attacking abasic sites, respectively. Apnl-deficient (AapnI) yeast mutants were sensitive to both oxidative and alkylating agents. In addition, the spontaneous mutation rate in $\Delta$ apnl mutants was at least 6 - to 12-fold higher than the rate measured for wild-type cells. Evidently, the production of mutagenic DNA lesions that are targets for Apnl is substantial under normal growth conditions. Immunofluorescence studies demonstrate that the Apnl protein is localized to the nucleus. The C-terminus of Apnl contains three segments rich in basic amino acids with possible nuclear localization signals, such as KKRK. Deletion analysis of the C-terminal region of Apnl revealed a signal necessary for localizing the protein to the nucleus. The shortest deletion, which generated a protein lacking the twelve C-terminal amino acids (SQMTKKRRTKKE) did not dramaticalls alter the enzymatic activities of Apnl in vitro, but clearly prevented the transport of this protein (Apnlass) to the nucleus. As determined from immunoblotting experiments, larger C-terminal truncations destabilized the protein, and those derivatives were cytoplasmically located. When it was overproduced in a $\Delta$ apnl mutant, the Apnlass enzyme provided wild-type resistance to methyl methane sulfonate, despite being located predominantly in the cytoplasm. This unexpected result suggests that enough of the Apnl ${ }_{39 s}$ enters the nucleus to repair critical DNA damages. Such residual nuclear transport could be mediated by the basic regions that remain in Apn $1_{23 s}$. Whether more limited expression Apn $1_{235}$ will suffice for repair of lethal alkylation damages is under investigation. Expression of Escherichia coli endonuclease IV (a homolog of Apni) in the $\Delta$ apni mutant decreased the cellular sensitivity to oxidative and alkylating agents. The overproduced endonuclease IV is not specifically localized to any cellular compartment in yeast, but enough may be present in the nucleus to effect repair. The main functions of the $\mathrm{C}$-terminal basic region of Apnl may be to stabilize the protein and signal its transport to the nucleus. 


\section{"Cellular Responses to Environmental DNA Damage"}

Interaction of the UvrABC Endonuclease with DNA Containing a Psoralen Monoadduct or Gross-link: Differential Effects of Superhelical Density and Comparison of Preincision Complexes. Maureen M. Munn and W. Dean Rupp. Departments of Therapeutic Radiology and of Molecular Biophysics and Biochemistry, Yale University School of Medicine, P.O. Box 3333, New Haven, Connecticut 06510.

The effect of negative supercoiling on UvrABC incision of covalently closed duplex DNA circles containing either a furan-side monoadduct or a cross-link of

4'-hydroxymethyl-4,5',8-trimethylpsoralen at a unique site was examined. The rate of UvrABC incision of these DNA substrates was measured as a function of superhelical density, $\sigma$, for values of $\sigma$ between 0 and -0.050 . The monoadducted DNA substrate was incised at close to the maximum rate at all superhelical densities, with only a slight stimulation of activity between $\sigma=0$ and -0.035 . In contrast, efficient UvrABC incision of the cross-linked DNA substrate required the DNA to be underwound, and activity showed a linear dependence on superhelical density up to $\sigma=-0.035$. DNase I protection studies show that in the presence of both UvrA and UvrB a protein complex binds to the site of a psoralen monoadduct or cross-link in linear DNA. This UvrA-UvrB-dependent complex binds with similar affinity to both the monoadducted and the cross-linked DNA helices. However, differences in the DNase I footprint on these two DNA substrates indicate that the interaction of this protein complex is different at these two lesions. The addition of UvrC to linear DNA molecules that are saturated at the site of the lesion with the UvrAUvrB-dependent complex resulted in efficient nicking of the monoadducted DNA, but not the cross-linked DNA. Thus, the properties of a DNA lesion site that lead to UvrAB recognition and binding are not necessarily sufficient to allow incision when all three Uvr subunits are present. We propose that after recognition and binding of a lesion site by the UvrAB complex and prior to incision, the damaged DNA helix undergoes a conformational change such as unwinding or melting that is induced by the lesion-bound Uvr complex. 


\section{Cellular Responses to Environmental DNA Damage}

DAMAGE RECOGNITION AND DISCRDMINATION BY THE E.COU UVRABC NUCLEASE COMPLEX. Amanda Snowden and Ben Van Houten. Deparment of Pathology, University of Vermont, Burlington, Vermont.

Damage recognition and incision steps of $E$. coli nucleotide excision repair are mediated by the UviABC nuclease complex. This enzyme complex recegnizes a variety of different DNA lesions presumably due to helical alterations caused by the DNA damage. In order to systematically analyze a structure-function relationship between the amount of helical distoition and the binding affinity, and incision efficiency of the UvrABC complex, we have constructed a series of structurally similar lesions which are present at a single site within a defined DNA sequence. Using these lesions we have shown that the UvrABC nuclease specifically incises apyrimidinic sites (AP) less efficiently than o-benzylhydroxylamine-modified AP sites (BA) (Biochemistry 29:7251-7259, 1990). The difference in incision appears to result from the interactions of the UvrA $B$ compl:x with the site of the DNA damage (JMB 220:19-33, 1991). Using the AP and BA lesions, gel shift assays are being performed to further investigate the formation of the protein-DNA intermediates involved in UvrABC mediated nucleotide excision repair. Specifically, the nature of the protein-DNA interactions involved at each step of damage recognition and discrimination are being examined. Using the gel shift'assay three unique complexes have been resolved. These appear to result from interactions of $\mathrm{UvrA}_{2}, \mathrm{UvrA}_{2} \mathrm{~B}$, and UvrB with the DNA containing the lesion. An examination of the components of these proteinDNA complexes will be presented. Gel shift analysis is also being used to determine equilibrium binding constants for the binding of the various UvrABC complexes to the AP and BA lesions. The estimated apparent dissociation constant (Kd) of UvrA for both an AP and a BA lesion is 1-2 $\times 10^{-9}$. Other equilibrium constants as well as kinetic rate constants for the formation of the complexes will be presented. A.S. is supported by Predoctoral Environmental Pathology Training Grant ES07122-09. 


\section{Cellular Responses to Environmental DNA Damage}

Examination of individual DNA repair events carried out by human cell extracts. David E. Szymkowski and Richard D. Wood, Imperial Cancer Research Fund, Clare Hall Laboratories, South Mimms, U.K.

We have constructed various covalently closed circular M13 viral genomes containing one DNA lesion per molecule in a specific location, and have studied the repair of these lesions in in oitro human cell-free extracts. The defined substrates we have synthesized include molecules with a cis-diamminedichloroplatinum-induced G-Pt-G intrastrand crosslink, a TT cyclobutane pyrimidine dimer, and a TT $(6,4)$ pyrimidine-pyrimidone dimer. The substrates were created by priming specially designed M13mp18 genomes with oligonucleotides containing defined adducts (damaged oligonucleotides were prepared in the laboratories of J. Essigmann and S. Lippard, MIT (Pt adduct) and C. Lawrence, U. Rochester (UV adducts)). Primed single-stranded DNA was converted to covalently closed double-stranded DNA by T4 DNA polymerase holoenzyme and DNA ligase. The product was purified on $\mathrm{CsCl}$ gradients for use in in vitro repair reactions.

The platinum adduct is located in a StuI recognition site; therefore the presence of the adduct could be confirmed by the inability of the substrate to be cleaved by this enzyme. The presence of the cyclobutane dimer was confirmed by the ability of T4 endonuclease V to convert the covalently closed circular DNA to nicked circles. If damaged primers were labelled with ${ }^{32} \mathrm{P}$ at the $5^{\prime}$ end, radioactivity was incorporated in the correct region of the circular product molecules.

The two dimer-containing and one platinum-containing substrate, plus controls, are being incubated with human cell extracts from repair-proficient and $X P$ cell lines, and synthesis in the area immediately around the site of damage is being measured as previously described (Hansson et al., 1989. J. Biol. Chem. 264, 21788-21792). We plan to determine the relative patch sizes and levels of synthesis of the single platinum and UV lesions repaired by cell extracts, and the effects on repair synthesis of preincubation with $E$. coli UvrABC.

We have examined, using an electron microscope, repair patches introduced by human cell extracts in UV-damaged plasmid DNA. The technique (carried out in collaboration with Dr. N. Hajibagheri, ICRF) involves replacing dTTP in the repair assay with biotinylated dUTP, so that biotin is incorporated into repair patches. Patches are then detected by addition of $10 \mathrm{~nm}$ diameter colloidal avidin-gold particles. From photomicrographs, estimates can be made of the size and distribution of excision repair patches introduced by mammalian cells. Most patches seen were on the order of 30 bases or less, and patches were distributed randomly among multiply-damaged plasmids, indicating that repair in this mammalian cell-free system may proceed via a non-processive mechanism. 
Cellular Responses to Environmental DNA Damage

A Buman Mlcking Enzymo Systen that Recogalzes O'-m66:I Pairs is Din Sibghat UIlah and Rufus S. Day, III. Molecular Genetics and Carcinogenesis Laboratory, Department of Medicine, Cross Cancer Institute, 11560 University Avenue, Edmonton, Alberta, T6G 122, Canada.

O'methylguanines ( $m 6 G$ ) are produced in cellular DNA by methylating agents such as MNNG. In normal cells m6G is repaired by the protein m6G DNA-methyltransferase. Mer cells, which lack this activity, are hypersensitive to MNNG in that they show elevated cell kiliing, mutagenesis, and SCE production. In addition MNNG-treated Mer cells incorporate more ${ }^{3} \mathrm{H}$-dThd into repaired regions of their DNA and show relaxation of their DNA supercoils for a prolonged period of time. These findings are consistent with the interpretation that MNG treated Mer cells recognize the $\mathrm{m} 6 \mathrm{G}$ but repair the DNA strand opposite the $\mathrm{m} 6 \mathrm{G}$. We therefore sought to characterize a nicking activity specific for m6G paired with dC or dT. We have used the cell free system of Manley et.al. (1980) to study nicking of 45-bp DNA substrates containing an $\mathrm{m} 6 \mathrm{G}$ base at a defined location. We have found that cell free extracts contain an activity which incises only the DNA substrate containing $\mathrm{m6G}: \mathrm{T}$ pairs and does not incise m6G:C containing DNA and that the activity incises only the $T$ strand. Analysis of the incision fragments obtained from substrates in which the $m 6 G$ strand was paired with $5^{\prime}$ or $3^{\prime}$ labelled $T$ strands revealed that the $5^{\prime}$ and $3^{\prime}$ phosphodiester bonds immediately adjacent to the $T$ opposite the $m 6 G$ are cleaved. Preliminary data showing the activity is different from G.T specific mismatch activity (which is also present in the cell free extract) are presented. Data are shown which preclude the possibility of artifactual conversion of $\mathrm{m} 6 \mathrm{G}: \mathrm{T}$ to $\mathrm{G}: \mathrm{T}$ by $\mathrm{m} 6 \mathrm{G}$ DNAmethyltransferase activity followed by G.T mismatch nicking action. 
Analysis of UvrABC endonuclease reaction intermediates on cisplatin damaged DNA using mobility shift gel electrophoresis. Rob Visse, Martina de Ruijter, Geri F. Moolenaar, and Pieter van de Putte. Laboratory of Molecular Genetics, Department of Biochemistry, Gorlaeus Laboratories, Leiden University P.O Box 9502 RA Leiden, The Netherlands.

The UvrABC endonuclease from Escherichia coli has the capability to repair a wide variety of DNA damages (for review see Van Houten, Microbiol. Rev. 54:18 (1990)). The endonuclease recognises not the damage itself but the local change in DNA conformation resulting from the damage. A UvrAB complex locates the damaged site in the DNA. Recently preincision complexes were isolated that contained only the UvrB protein (Orren and Sancar P.N.A.S. 86:5237 (1989), Orren and Sancar J.B.C. 265:15796 (1990)) and therefore it was suggested that UvrA catalytically delivers UvrB onto the damaged site in the DNA. At this time is not known whether the release of UvrA from a UvrAB.DNA complex is essential for incision to occur. The processing of different damages is conserved as the damage containing strand is incised on both sides of the lesion which is then removed as an oligonucleotide of $12-13$ bases. The efficiency of repair is determined by 2 steps 1) recognition of the damaged site 2) processing. Not all damages in the repertoire of UvrABC are repaired with the same efficiency and therefore the analysis of complex formation and preincision complex(es) can help to gain insight in the parameters that are determinants for efficient repair.

A gel mobility shift electrophoresis method is described that visualises excision repair reaction intermediates. Incubation of UvrA and UvrB with a synthetic DNA fragment containing a specific cisplatin adduct (cis-Pt.GG intrastrand crosslink) revealed 2 bands which could be identified with the help of specific antisera as a UvrAB.DNA and a UvrB.DNA complex. At low UvrA concentrations in the presence of UvrB only the UvrB.DNA complex is observed indicative of a relative fast conversion of UvrAB.- to a UvrB.DNA complex. Bands corresponding to the UvrAB.DNA and aspecific complexes are found at relatively high UvrA concentrations. The gel mobility shift method was used to footprint the specific Uvr.DNA complexes. The UvrA footprint was found to protect an area of approximately 37 bases. The DNaseI footprint of the UvrAB.and UvrB.DNA complex are very similar and cover about 20 bases. In both the UvrAB and the UvrB footprint DNaseI sensitive sites are present. The DNaseI sensitive sites indicate that the complex has undergone a conformational change. Both the UvrAB.- and the UvrB.DNA complex are incised in the presence of UvrC with comparable efficiency. The UvrAB.- and the UvrB.DNA complex were both incised at the 8th phosphodiesterbond $5^{\prime}$ to the specific cisplatin adduct. In addition the UvrAB.DNA complex could also be incised at the 15th phosphodiesterbond $5^{\prime}$ to the damaged site (Visse et al J.B.C 266:7609 (1991)). The results suggest that the UvrB.DNA complex is the substrate for UvrC induced incision in vivo.

This work was supported by the J.A. Cohen Institute for Radiopathology and Radiation protection (I.R.S.) project 4.2 .6 
$0^{6}$-methylguanine mispair recognition by the: Muts and other E.coli binding activities.

E. Maldstein and $A$. Khodursky

Department of Biochemistry, Tel-Aviv University, Israel

The genotoxic potential of simple N-nitroso compounds depends to a great extent on their capacity to form adducts at the $0^{6}$-position of guanine $\left(0^{6} \mathrm{G}\right)$ as well as on the cellular ability to eliminate these adducts through repair. Unrepaired $\mathrm{C}^{6} \mathrm{G}$ when replicated tend: to $\mathrm{f}_{\mathrm{g}} \mathrm{O}^{6} \mathrm{G} . \mathrm{T}$ base mispairs instead of $0^{6} \mathrm{G} . \mathrm{C}$. We have asked whether $0^{6} \mathrm{G} . \mathrm{T}$ and $0^{6} . \mathrm{C}$ can be recognized by the Muts protein, the key protein of two different repair pathways one of which repairs any natural base mismatch whereas the other operates on G.T mismatches only.

The interaction with the Muts protein has been tested in gel-retardation experiments and by southwestern assays. Synthetic 34 mer duplex molecyles with a centrally located $0^{\circ}$ methylguanine $\left(0^{6} \mathrm{mG}\right)$.T or $0^{6} \mathrm{mG} . \mathrm{C}$ mispair and the relevant control duplexes were used as substrates. The $E$. coli and S.typhimurium Muts protein recognized not only the natural G.T mismatch but did also bind to $0^{6} \mathrm{mg} . \mathrm{C}$ and especially to $0^{6} \mathrm{mG}$.T mispairs. Competition experiments confirmed that the binding affinity of the Muts protein to the substrates decreased in the following order: $0^{6} \mathrm{mG} . T>G . T>0^{6} \mathrm{mG} . \mathrm{C}$. Our data suggest that modified base mismatch recognition by the Muts protein involves sensing of local destabilization and possibly, conformational effects of the $0^{6}$ mg on the DNA.

In the extracts of $E$. coli the presence of two additional $0^{6} \mathrm{mG} . \mathrm{T}-$ and $0^{6} \mathrm{mG} . \mathrm{C}-\mathrm{binding}$ activities have been demonstrated. Unlike to kuts they did not bind to the unmodified G.T mismatch. One of them had a MW of $31 \mathrm{kDa}$ and preferred $0{ }^{\mathrm{mg}} \mathrm{m}$.T as a substrate. The second was lost after $3 \mathrm{M}$ ammonium sulfate precipitation and its nature so far remained unresolved. It nevertheless showed a distinct preference for ObmG.C as a substrate.

E. coli muts mutants showed a slightly higher MNNGsensitivity both in survival and mutagenicity tests. overproduction of the Muts protein did not improve the biological resistance relative to the wild type condition. These data suggest that only a certain population of $0^{6} \mathrm{mg}$ lesions might be subjected to the influence of the Muts protein. The biological role of the two other binding activities has to await further analysis. 
Euman Enzymatic Activities Which Remove 31 -Phosphoglycolate Termini at DW 8trand Breaks. Thomas A. Winters', Michael Weinfeld ${ }^{2}$ and Timothy J. Jorgensen': 'Department of Radiation Medicine, Georgetown University Medical Center, Washington DC, USA: 2Radiobiology Program, Cross Cancer Institute, Edmonton, Alberta, Canada.

DNA strand breaks induced by free radical producers, such as ionizing radiation or bleomycin, can have phosphoglycolate termini as the $3^{\prime}$-end-group of cleavage. For DNA treated in vitro with ionizing radiation or bleomyçin under aqueous oxic conditions, $3^{\prime-}$ phosphoglycolates (3'-PG) are present at approximately 50 to 100 percent of the strand break sites. The $5^{\prime}$-end-grcup of cleavage in all cases is a phosphate $\left(5^{\prime}-\mathrm{P}\right)$. Since DNA strand breaks with $3^{\prime}-$ PG and 5'-p involve base loss, repair of these lesions must require a DNA polymerase, to replace the missing base(s). DNA polymerases, however, require substrates with $3^{\prime}$ hydroxyl groups $\left(3^{\prime}-O H\right)$ and cannot use $3^{\prime}-P G$ as a primer for synthesis. Prior conversion of $3^{\prime}-$ PG to $3^{\prime}$-OH is, therefore, necessary for DNA strand break repair to proceed.

We have purified three chromatographically distinct human enzymatic activities, from extracts of Hela cells, that can remove 3'-PG from bleomycin treated DNA. The enzymes were originally identified and purified based on their ability to convert bleomycin-treated DNA into a substrate for DNA polymerase. purification was achieved by sequential chromatography on DEAEcellulose, phosphocellulose, and DNA-cellulose. The three activities were finally resolved by Mono-P chromatofocusing.

3'-PG represents greater than $95 \%$ of the dose dependent lesions in DNA treated with bleomycin under our exposure conditions, as assessed by a ${ }^{32}$ p-postlabeling gel electrophoresis assay. We have shown that these purified enzymes remove 31 -PG from DNA. Their 3'-PG removal activity correlates with the extent of nucleotide incorporation, suggesting that incorporation is dependent upon the removal of 3'-PG.

In $E_{\text {. coll }}$, strand break repair may involve exonuclease III or endonuclease IV. Both of these prokaryotic enzymes also have an accompanying Class II apurinic endonuclease activity. We have shown that human enzymes we have purified, likewise, possess Class II apurinic endonuclease activity. Exonuclease III and endonuclease IV differ in that endonuclease IV lacks $3^{\prime} \rightarrow->5^{\prime}$ exonuclease activity. The human enzymes described here are similar to endonuclease IV in this regard.

[Supported by CA48716 awarded by the National Institutes of Health, DHAS . ] 
Cellular Responses to Environmental DMs Damage

Analysis of Formation and Persistence of Environmental Polycyclic Aronate Hydrocarbon-DMA Adducts by ${ }^{35}$ S-Phosphorothloate Postlabeling-HPLC Techniques. Hudson H.S. Lau, Sherry L. Brozlch, Stephanie L. Coffing, Robert J. Kauthe and Willfan K. Bafrd, Department of Medicinal Chenistry, School of Pharmacy. Purdue University, West Lafayette, IN 47907.

The polycyclic aromatic hydrocarbons (PAH) are widespread emvlromental contaminants: some are very potent carcinogens in rodent bloassays and ovidence Ilnke certain human cancers to exposure to PAH. Studies with benzo(a)pyrene (BaP) have demonstrated that one optical isomer of Bap-7,8diol-9,10-epoxide (BaPDE) is an "ultinate" carcinogenic metabolite in rodents, but the three other optical isomers have only weak carcinogenic activity. This result indicates that to relate the formation and repair of hydrocarbonDNA adducts to cancer induction, it is essential to be able to analyze the DKA adducts formed frov each optical lsomer of a PAH-diol-opoxide. To allow the analysis of very low levels of Bap-adducts with the high resolution possible with HPLC, Lau \& Baird (Carcinogenesis 12: 885, 1991) developed a postiabeling procedure uning 35 s-phosphorothioate as the label and analysis by HPLC coupled to a radiolsotope flow detector. This systen resolves the major BaP-DMA adducts, but does not completely separate some of the syn isomer of BaPDE-DMA adducts fron certain anti 1soner of BaPDE-DNA adducts. A procedure has now been developed for labeling the BaP-DNA adducts with 39s-phosphorothioate, separating the syn fron the anti 1somer BapDE-DNA adducts by immobilized boronate chromatography, and analyzing the Individual adducts by HPLC. This procedure requires the use of immobllized boronate polyacrylanide gel to provide a high capacity boronate column and 2-mercaptoethanol; In the buffer to protect the phosphorothloate from oxldation. The adducts must then be passed through a $C_{10}$ disposable Sep-Pak cartridge and eluted with methanol:ammonia to remove the boronate elution buffer prior to HPLC. The syn BaPDEphosphorothloate adducts were separated best by reverse-phase HPLC and the anti BaPDE phosphorothloate adducts were completely resolved by lon palr reverse-phase HPLC. This technique allows complete analysis of all BaPDE-DNA adducts formed in Bap-treated mammalian cell cultures with an estimated detection limit of 0.1 pmole adduct/mg DNA for a 20 Hg DNA sample.

The above procedure is especially valuable for studies of hydrocarbons not avallable with a radiolsotope label or studies in which the use a radiolsotope-labeled PAH is not feasible. It has now been adapted for analysis of the DNA adducts of the potent environmental carcinogen dibenzo $(a, 1)$ pyrene (DBalp). Early passage mouse embryo cell cultures and the human mammary carcinoma cell line MCF-7 both activate DBalP to form six major DNA adducts after 6,24 and 48 hours of treatment. The adduct present in the greatest amount differs between these two types of cells. The proportion of these adducts formed by the ant 1 and syn isomers of DBalP diol-epoxide is presently being Investigated by Immobilized boronate chromatography and HPLC.

The phosphorothloate postlabeling technique is now being used to investigate the formation and the persistence of the DNA adducts formed by specifle optical 1somers of environmental PAH diol-epoxides in order to assess the role of Individual adducts in the Induction of mutation and carcinogenesis. (Supported by NCI grants CA28825 and CA40228). 
Cellular Zesponses to Environmental DNA Damage

Quantitative and Qualitative Influences of Nitroimidazole Radiosensitizers on DNA Damage. Garry W. Buchko and Michael Weinfeld. Radiobiology Department, Cross Cancer Institute, Edmonton, Alberta, Canada.

Nitroaromatic heterocyclic compounds that sensitize radioresistant hypoxic tumour cells to the therapeutic effects of fonizing radiation have been extensfvely studied over the past two decades (1). However, the underlying molecular mechanisms of radiosensitization by these agents remain poorly understood, We have employed a variety of assays, including a newly developed 32p-postlabelling assay (2), to examine the influence of misonidazole [1(2-nitro-1-imidazoyl) 3-methoxy-2-propanol] on radiation-induced DNA damage.

When DNA was irradiated aerobically, misonidazole, at concentrations of $50 \mu \mathrm{m}-5 \mathrm{~mm}$, was observed to act as an efficient radioprotector. Indeed, at the highest concentration virtually no base or sugar damage was detected. Analysis of the DNA samples by agarose gel electrophoresis indicated that this protection also applied to the formation of single- and double-strand breaks. Using N-methyl-2-nitroimidazole and 1-methoxy-2-propanol as model compounds for the misonidazole ring structure and side chain, respectively, we have shown that both moleties contribute towards the protection by misonidazole, but the contribution by the nitroaromatic ring is predominant.

In the anaerobic irradiation of DNA, two competitive actions of misonidazole were evident; a protective effect seen most clearly at high drug concentration $(5 \mathrm{mM})$, and a sensitization revealed at lower concentration $(5-50 \mu \mathrm{M})$. The sensitization was almost entirely restricted to the enhanced formation of phosphoglycolate groups. These lesions, found at the $3^{\prime}$-DNA termini of strand breaks, arise from attack at the $4^{\prime}$-carbon atom of deoxyribose residues within DNA. This is the first time that any specific lesion has been attributed to the presence of misonidazole during anaerobic irradiation of DNA. It remains to be seen whether attack at the $5^{\prime}$-carbon atom of deoxyribose occurs, giving rise to strand breaks with $3^{\prime}$-phosphate termini. We are currently using an approach developed by Henner et al. (3) to answer this question.

We have also shown that etanidazole, a nitroaromatic sensitizer curreritly undergoing clinical trials, has the same sensitizing and protecting properties as misonidazole.

1. Wardman, P. (1987) Radiat. Phys. Chem. 30, 423-432.

2. Weinfeld, $M$. et al. (1991) Biochemistry $30,1091-1097$.

3. Henner, W.D. et al. (1982) J. Biol. Chem. 257, 11750-11754.

This work was supported by a grant from the National Cancer Institute of Canada and an Alberta Cancer Board Fellowship to G.W.B. 
"Cellular Responses to Environmental DNA Damage"

Detection of native and proteolyzed poly(ADP-ribose)polymerase by western and activity blot in human leukemia cells treated with etoposide. Serge Desnoyers, Guy G. Poirier, and Scott H. Kaufmann. Laboratory of poly(ADP-ribose) metabolism, Molecular Endocrinology dept, Laval University Medical Center, Ste-Foy (Quebec) G1V 4G2 (S.D. and G.G.P.). Cell Structure and Function Laboratory, The Johns Hopkins Oncology Center, Baltimore, MD 21205 (S.H.K.).

Treatment of HL-60 human progranulocytic leukemia cells with the topoisomerase II-directed chemotherapeutic agent etoposide (VP-16) has been shown to result in endonucleolytic DNA degradation (S: H. Kaufmann, Cancer Res. 49: 5870,1989). Durig this treatment, the cellular NAD content rapidly diminishes, indicating that poly(ADP-ribose)polymerase ( $\mathrm{PADPRp}$ ) has been activated by the DNA breaks. In the present study we have examined the integrity and activity of pADPRp during these events.

Blotting with monoclonal antibody C-II-10 (directed against an epitope located at the carboxy terminal of the DNA binding domain) revealed that the $116 \mathrm{kDa}$ pADPRp polypeptide was degraded to a relatively stable $85 \mathrm{kDa}$ fragment. Blotting with an antiserum raised against the second zinc finger of pADPRp (anti-F2) indicated that F2 was absent from the $85 \mathrm{kDa}$ fragment and was instead contained in a $23 \mathrm{kDa}$ fragment. This result suggested that proteolysis was occuring between the second zinc finger and the automodification domain of pADPRp. Consistent with this result, assays performed on nitrocellulose-immobilized extracts after SDS-PAGE revealed that the $85 \mathrm{kDa}$ fragment retained PADPRp activity. Unlike the intact $116 \mathrm{kDa}$ polymerase, the $85 \mathrm{kDa}$ fragment could not be activated by exogenous nicked DNA.

Additional studies revealed that a similar fragment of pADPRp was generated when human leukemia cells (HL-60, KG1a, Molt 3, Molt 4) were treated with a variety of mechanistically diverse cytotoxic agents including cytosine arabinoside, methotrexate, cis-platinum, colcemid, camptothecin, and cycloheximide. In each case, the proteolysis of pADPRp and the internucleosomal degradation of DNA occurred over similar time courses and preceeded the loss of plasma membrane integrity (trypan blue uptake) by several hours. These results indicate that proteolysis of pADPRp to a DNA-insensitive $85 \mathrm{kDa}$ fragment is an early event which accompanies DNA degradation during apoptosis in hvman leukemia cells treated with a variety of agents.

Supported by NIH, MRC and FCAR. 


\section{Cellular Responses to Environmental DNA Damage}

Detection of Adenine Photoproducts In Vivo in Human Lymphoblasts Using a Bacterial UV-Endonuclease as a Probe. Leonora J.Groves Randi B. Weiss, and Patricia E. Gallagher. West Virginia University, Department of Biology, Morgantown, WV 26508.

While the ultraviolet mutagenesis and carcinogenesis of pyrimidine photoproducts have been extensively investigated, DNA purines were long assumed to be relatively inert to photochemical modification. However, several purine photoproducts, Including two distinct adenine dimers, have been detected in vitro in ultraviolet irradiated dinucleotides, polynucleotides and DNA. The 8,8-adenine dehydrodimer is formed by the covalent linkage of the C8 atoms of two adjacent adenine nucleotides. A second, separable adenine photoproduct is formed by a covalent linkage between the N7 and C8 of the 5' adenine and the C6 and C5 atoms of the 3' adenine, respectively. Here we describe the purification of a bacterial endonuclease which incises ultraviolet irradiated DNA at sites of adenines. This adenine-photoproduct ineising activity was then used as a probe to detect the formation of enzyme-sensitive sites in DNA extracted from ultraviolet irradiated human colls.

Using ultraviolet irradiated poly(dA)-poly(dT) labeled with [8-3H]-dATP as a substrate, an enzymatic activity which recognizes adenine-containing photoproducts was isolated from $E$. coli. This enzyme was separated by ion-exchange chromatography from other known bacterial endonucleases which incise ultraviolet Irradiated DNA. The partially purified enzyme specifically released radiolabeled material from the purine strand, showing no activity against ultraviolet irradiated polymer radiolabeled in the pyrimidine strand. In addition, the enzyme did not release TCA-soluble material from ultraviolet irradiated poly(dA-dG)-poly(dT-dC) radiolabeled with [8-3H]-dATP. This suggests that the enzymatic activity is directed against adenine-containing photoproducts in ultraviolet irradiated polynucleotide and not toward structural distortions of the substrate induced by the formation of bipyrimidine photoadducts. Analysis of data generated from a DNA sequencing assay showed that the partially purified enzyme incised ultraviolet irradiated DNA at sites of adenine residues in regions of the substrate containing multiple adjacent adenines. These data suggest that the enzymatic activity is directed against adenine photodimers in DNA. Since the radiolabel is retained upon ultraviolet irradiation of the polynucleotide, this indicates that the structure of the recognized photoproduct is not an 8,8-adenine dehydrodimer.

The adenine-photoproduct incising activity was used as a probe to detect the formation of purine photoproducts in vivo in human lymphoblasts. Human lymphoblasts were treated with increasing, non-lethal doses of ultraviolet irradiation and damaged DNA was isolated. Following incubation of the DNA with the partially purified enzyme, the formation of enzyme-sensitive sites in total genomic DNA was determined by alkaline sucrose density gradient centrifugation. Using this method, the rate of in vivo repair of these adenine photoproducts is currently under investigation. (Supported by NIH grant CA-47457 and WVU Sentate Grant). 
-Cellular Responses to Environmental DNA damage"

In vivo effects of site-specific 8-hydroxyguanine residues in human cells: evidence for processing by excision repair

Johanna C. Rlein, Maria J. Bleeker, Harlof C.P.F. Roelen', Christiaan P. Saris, Johannes G. Westra, Gijs A. van der Marel', Jacques H. van Boom ${ }^{2}$, Anton J. M. Berns, Erik Kriek.

Netherlands Cancer Institute, Amsterdam and 'Gorlaeus Laboratory, University of Leiden, The Netherlands

8-Bydroxyguanine (8-OHG) is considered to be one of the mutagenic DMA modifications formed by oxygen radicals. This residue has been shown to be highly miscoding during replication with purified DNA polymerases in vitro. Wo transfected several human cell lines with plasmids that carried a single 8-OHG at a unique site, in order to determine the in vive mutagenicity. We found that only 2-3s of the progeny plasmids were mutated at the site of modification, irrespective of the type of cell line used. In all cases, 30-50 of the mutations consisted of single $G \rightarrow T$ transversions at the former position of the modified $G$. We also found that the survival of modified plasmids was strongly reduced ( 1808 ) in XP-A cells, while it was not in HeLa célls, normal fibroblasts and XP-A revertant cells. As a control, we performed a similar analysis with constructs that carried an 8-acetylaminofluoreneguanine at the same position. In this case the mutalion frequencies were less than 1 in all cell lines, and also the mutational spectra were different than those observed with 8-0HG. Witt. respect to the survival of the modified plasmids in the different cell types, we again observed a strong reduction (2 958) only in the XP-A cells. From this we concluded that both 8-OHG and 8-AAFG are not repaired and block DNA replication in XP-A cells. Thi.s suggests that like 8-AAFG, also 8OBG residues raay be substrate for excision repair. 


\section{Cellular Responses to Environmental DNA Damoge}

DNA containing modified intemucleotide pyrophosphate linkages are substrates for Escherichia coll repair endonucleases.

Andrel A. Purmal, Robert J. Melamedo and Yoke W. KoY.

Department of Microblolooy and Molecular Genetics, University of Vermont. Burlington. VT 05405

DNA substrates containing modified internucleotide pyrophosphote linkages are useful for the study of the mechanism of action of repair enzymes from Escherichla coll. Oligonucleotides containing a pyrophosphote bond. $3^{\prime}$ or $5^{\prime}$ to an abasic (AP) site was prepared by the action of uracil DNA olycosylose on DNA containing a pyrophosphote bond adjacent to a single uracil residue. Two 27member DNA fragments contalning a pyrophosphate bond adjocent to AP site were prepared. One ollgonucleotide contained a pyrophosphate bond 5 to the AP site:

5'- GGTCGACTCTPP(AP)AGGAGGATCCCCGGGTAC-3' (1)

and the other a pyrophosphate bond $3^{\prime}$ to the AP site:

5'- GGTCGACTCTCAPPPAGGAGGATCCCCGGGTAC-3' (ID

We expected that DNA duplexes containing pyrophosphate $5^{\prime}$ to the AP site (duplex D could be resistant to the hydrolytic activities of endonuclease $N$ and exonuclease III (5 $5^{\circ}$ AP endonucleases) but not to the $\beta$-elimination activity of endonuclease III or B,8-elimination activity of endonuclease VIII (3. AP lyases). Similarty, duplexes containing a pyrophosphate bond $3^{\prime}$ to the AP site (duplex ID) should not prevent the enzymatic nicking of the AP site by these enzymes.

We found that duplex I (pyrophosphate on the $5^{\circ}$ side) was resistant to nicking not only by endonuclease $N$ and exonuclease III, but surprisingly, also to endonuclease III. The inability of endonuclease III to cleave the AP site in duplex I was unexpected since endonuclease III incises $3^{\prime}$ to the DNA lesion. In contrast. duplex I was found to be a substrate for endonuclease VIII which also incises $3^{\prime}$ to the lesion but rate of cleavage was 10\% of that of the normal DNA substrate.

Duplex II (pyrophosphote on the 3' side) was resistant to cleovage by both exonuclease III and endonuclease III. The inability of exonuclease III to nick duplex $N$ was unexpected for exonuclease III hydrolyses the phosphodiester bond 5' to the AP site. Interestingly, for endonuclease Vill, the cleovage of duplex $N$ was partially inhibited. It appeared that the presence of pyrophosphate bond of the $3^{\circ}$ side of AP site partially Inhibited the B-elimination process of endonuclease VII reaction. leading to the formation of both the $\beta$ - and sellmination products. However, duplex II was a good substrate for endonuclease N.

The thermal stability of the AP site in duplexes I and II were found to be similar to a normal duplex containing an AP site. Based on this and the substrate specificities of the enzymes used. We suggest that the electrostatic interaction of the enzymes with the phosphodiester bond $3^{\prime}$ and $5^{\prime}$ to the lesion ploys a mojor role in the binding of these proteins to the DNA damage. The presence of extra charges due to the pyrophosphate bond in the vicinity of the DNA damage interfered with the binding of the enzyme to the DNA damage and resulted in the lock of or reduced rote of DNA nicking. In order to further examine this ldea, duplexes containing a pyrophosphate bond 2 and 3 bases awoy from the AP site hove been prepared and the positional effect of the pyrophosphate on the enzymatic recognition of the AP site will be discussed. 
Repair of Radiation-Induced DNA Double Strand Breaks Measured by PulsedField Gel Electrophoresis. Raymond E. Meyn and Michael D. Story, The University of Texas M.D. Anderson Cancer Center, Houston, TX 77030, U.S.A.

We have used the method of pulsed-field gel electrophoresis (PFGE, developed for the resolution of very large ( $>10^{6}$ base Mbp) DNA fragments, to analyze the induction and repair of double strand breaks (DSBs) in mammalian cells. Two different approaches have been used. In the first, a human colon cancer cell line. which has the unique feature of being amplified for the epidermal growth factor receptor (EGFR) gene in the form of double minute (DM) chromosomes was used We showed using the clamped homogeneous electrical field (CHEF) version of PFGE that these DMs will not enter an agarose gel unless fragmented by radiation consistent with their ctrcular structure. Cells were irradiated with 30 Gy and incubated for various times prior to being prepared for PFGE. Following electrophoresis, the DNA fragments were transferred to nylon membranes and hybridized with labeled EGFR gene probe. The resulting autoradiogram for the tradiated control showed two band of 16 and $0.8 \mathrm{Mbp}$. With repair incubation these bands lost intensity as a function of time illustrating the rejoining of the DSBa.

In the second approach, $14 \mathrm{C}$-thymidine-labeled $\mathrm{CHO}$ cells were exposed to ionizing radiation $(30 \mathrm{~Gy})$ and subjected to CHEF-PFGE. the conditions of electrophoresis were adjusted such that the fragmented DNA moved out of the plug and into a compression zone. After elec_rophoresis the areas of interest were cut out of the agarose gel and the gel slices were melted and assayed for $3 \mathrm{H}$ radioactivity to determine the proportion of fragmented DNA. Repair of DSBs in these cells was quantitated in this manner. Moreover, when the frequency of incuction of DSBs was compared in intact cells versus naked DNA the dose response curves generated using this approach indicated that the naked DNA was 50 times more sensitive to DSB induction. These results suggest a large modulating efect of the intracellular milieu on DSB induction by radiation. 


\section{Cellular Responses to Environmental DNA Damage}

Granulocyte produced N-chloramines are potent naturally occurring irreversible inhibitors of DNA repair. Bonald W. Pere 1,2, Walter Trolf and Krystyna Frenkel?, IWallenberg Laboratory, University of Lund, Box 7031, S-220 07 Lund, Sweden and ${ }^{2}$ NYU Medical Center, Dopartment of Environmental Medicine-PHL 875, 550 First Avenue, Now York, New York 10016.

DNA repair assessed by ADP-ribosylation levels and unscheduled DNA synthesis (UDS) has been shown to be reduced in the mononuclear leucocytes (ML) from patients with cancer or the genetic predisposition to develop it (reviewed in Carcinogenesis 10:693-697, 1989; lbid 10:1657-1664,1989). These effects on DNA repair have been attributed to the repair of bulky DNA lesions not short patch repair of single strand breaks, and the process was dependent on redox balance (Cancer Res. 50:4619-4625, 1990). Adenosine diphosphate ribosyl transferase (ADPRT) is a sulhydryl enzyme which binds to DNA, and there are sulhydryl amino acids located at the base of the zine fingers. We have hypothesized that oxidation of the sulhydryl amino acids at the base of the zine fingers will prevent DNA binding of ADPRT and subsequent inhibition of DNA repair will oseur where this enzyme is invnlvad We have observed that when granulocytes are incubated together with ML in 1:1 portions, there is a $>50 \%$ inhibition of constitutive ADPRT and $>90 \%$ inhibition of hydrogen peroxide activated ADPRT. This inhibition was irreversible biochemically but ineubation of ML in the plesericu of $10 \mathrm{mM}$ aminotrlazole (a myeloperoxioase inhibitor) proventod tho gronulocyto produesd intibition of ADPRT. Thit pliysutuyic production of N-chloramines requires myeloperoxidase mainly from granulocytes, chloride and hydrogen peroxide (Science 222:625-628,1983). Chloramine T. a model N-chloramino, grves a dose dependont oomploto inhibition (1.e. al 10 uMM of ADPRT activity, UDS and polyclonal mitogenic stimulation of ML Taken together these data implicate that granulocyte production of $\mathrm{N}$-chloramines under conditions of oxidative stress have a strong regulatory influence over the immune function of ML as is evidenced by inhibition of DNA repair and Imyphocyte growth responses to mitogens. 


\section{"Cellular Responses to Environmental DNA Damage" .}

Formation of 8-hydroxydeoxyguanine within DNA of mouse keratinocytes exposed in culture to ultraviolet light. Blake C. Beehler, Joseph Preybyszerskl, Harold C. Box and Molly F. Rulesz-Martin. Roswell Park Cancer Institute, Buffalo New York.

Exposure to ultraviolet light (UV) contributes to the development of skin cancer. The importance of reactive oxygan species in UV-radiation carcinogenesis has been recognized for some time and several associated DNA base modifications have been identifled. In particular, 8hydroxydeoxyguanine (8-OFdG) has been well studied as an indicator of oxidative damage to calf thymus DNA exposed to a variety of oxygen-generating systems, including uv light. However, to date, few studies of 8-0HdG have been conducted in cell or animal systems. While most of the work on the induction of 8-OHdG in DNA has been performed using monochromatic UVC $(254 \mathrm{~nm})$, the UV light to which organisms are exposed through sunlight is in the UVB (290-320 $\mathrm{nm}$ ) and UVA $(320-400 \mathrm{~nm})$ range. UVB is thought to be primarily responsible for the solar carcinogenic effect. The objective of this study was to measure 8-okdG formation in the DNA of cultured mouse keratinocytes (a wellcharacterized skin carcinogenesis model) exposed to monochromatic UVC $(254 \mathrm{~nm})$ or monochromatic UVB (310nm). Using high pressure liquid chromatography with electrochemical detection, 8-okdG was quantified in DNA isolated and digested to the nucleoside level. Background levels of 8-OHdG were approximately $6 \mathrm{fmoles} / \mu \mathrm{g}$ DNA in these experiments. Monochromatic UVC increased 8-oHdG formatiog $83 \%$ above that for untreated cells at a dose of $30 \mathrm{~mJ} / \mathrm{cm}^{2}$ (increasing from 32 to 1098 of controls with increasing UVC dose from 9 to $60 \mathrm{~mJ} / \mathrm{cm}^{2}$ ). Interestingly, monochromatic UVB induced 8-OHdG up to $100 \%$ above that for mock treated cells at a dose of $990 \mathrm{~mJ} / \mathrm{cm}^{2}$ (dose response range 330 to 990 $\mathrm{mJ} / \mathrm{cm}^{2}$ ). Hydroxyl radicals generated by the activation of monochromatic UVB on $\mathrm{H}_{2} \mathrm{O}_{2}$ enhanced its effect throughout this dose range. Simultaneous exposure to $10 \mathrm{mM} \mathrm{H}_{2} \mathrm{O}_{2}$ and monochromatic UVB at $990 \mathrm{~mJ} / \mathrm{cm}^{2}$ elevated 8-OKdG formation up to 3508 above that in control cells, compared to $100 \%$ in cells exposed to UVB alone and no effect of $\mathrm{H}_{2} \mathrm{O}_{2}$ alone. These results suggest that increased 8-OHdG - formation by Uv light in mouse keratinocytes involves reactive oxygen species that may play a role in the mechanism of UVradiation carcinogenesis. 
Cellular Responses to Environmental Damage

Microfluorometric Size Measurements of Human DNA Correlate with the Degree of in vitro Cisplatin Treatment. Nicholas d.Bampine, Bldg. 10, Rm. 6C101, NICHD, NIH, Bethesda MD 20892.

Microfluorometric size measurements have been taken on DNA molecules to study the effects of the anticancer drug cisplatin on the proofreading activity of the enzyme T4 polymerase. The anticancer drug cisplatin has been shown to inhibit the $3^{\prime}-5^{\prime}$ exonuclease activity of this enzyme, and a microfluorometric assay that can measure the relative sizes of cisplatin treated human and phage DNA, after exposure to T4 polymerase, has been described [Rampino \& Johnston, Biochem Biophys Res Commun 179, 1344 (1991)]. Using phage DNA size standards, it was shown that the integrated fluorescent density (IFD) of fluorophore labeled DNA is linearly related to molecular size. Enzymatic digestion by T4 polymerase of cisplatin treated lambda DNA yielded fragment sizes whose mean IFD was logarithmically related to the degree of platination.

This microfluorometric method of size determination is now being applied to measure the degree of platination in genomic DNA isolated from human ovarian carcinoma cell lines that are either drug sensitive or drug resistant. The assay appears sensitive to cisplatin concentrations near the $I_{30}$ points, and potentially promising for the clinical analysis of altered DNA in cell populations after treatment with cytotoxic agents that induce exonuclease inhibiting adducts. 
"Cellular Responses to Environmental DNA Damage"

UV-INDUCED PERTURBATION OF ALTERNATIVE DNA SECONDARI STRUCTURES. Silvia Tornaletti, Annalisa Lanza, Elavia Spirito and Antonia $M$. Pedrini. Istituto di Genetica Blochimica ed Evoluzionistica del C.N.R.. Pavia - Italy.

DNA is a polymorphic molecule able to assume a number of alternative secondary structures, as a function of the degree of supercoiling, the base sequence and protein interaction. Examples are cruciforms, which form from inverted repeats sequences, $z$ DNA, in alternate purine-pyrimidines sequences, stable unwinding. in $A+T$ rich regions. Many evidences indicate that alternative DNh secondary structures are involved in many biological processes. such as initiation of DNA replication and transcription, recombination and mutagenesis.

We have initiated a study aimed to the understanding whether ov damage may affect DLA structural polymorphism, with particular attention to the formation and stability of cruciform structures. As DNA substrata we have used the plasmids pAT153 and pIRbke8, two pBR322 derivatives, which contain three inverted repeats (major, minor and subminor) at the terminator of ampR gene, that extrude to cruciform, according to a s-type mechanism; in addition, pIRbkes contains a synthetic inverted repeat, bke, inserted in the Bamli site. While in the bke palindrome the sequences with the highest probability to form pyrimidine dimers are in the cruciform loop, in the other inverted repeats they are mainly at the stem junction. In addition these plasmids contain, in the promoter and terminator of ampR gene, two A+T Iich regions, which can undergo stable DNA unwinding. Using $P 1$ endonuclease as a probe for the analysis of UV-induced structural transitions, we found that: i) UV irradiation at $254 \mathrm{~nm}$ stimulated the formation of sites sensitive to PI endonuclease; ii) the number of UV-induced P1 sensitive-sites was from 10 to 70 times lower with respect to pyrimidine dimers and seemed to be dependent on the conformation of the topologically closed domain. It was higher when cruciform structures were present; iii) UVinduced $P 1$ sensitive-sites appeared, at least in part, localized at discrete positions of the molecule, corresponding to the $A+T$ rich regions of the promoter and terminator of amp gene; iv) UV irradiation caused cruciforms readsorption as well as inhibition of their extrusion: $v$ ) analysis of dimer distribution on plasmid pAT153 DNA has shown that, at UV doses forming few damage per molecule, dimers do not appear randomly distributed but localized at discrete positions in the molecule. These results suggest the possibility that UV damage not only causes local perturbations of DNA structure, but, by affecting the dynamic nature of DNA, also influences the stability and the formation of alternative secondary structures.

Work supported by P.F. Ingegneria Genetica, C.N.R.. 
Cellular Responses to Environmental DNA Damage

PEROXYL FREE RADICAL-INDUCED OXIDATIVE DNA LESIONS IN PBR322

\author{
Iwhani A. Vilpe, Leena M. Vilpo and Timo J. A. Metsa-Ketela
}

Department of Clinical Chemistry, Tampere University Hospital, and Department of Biomedical Sciences, University of Tampere, SF-33520 Tampere, Finland.

We have used covalently closed circular double-strand DNA (CC) of native plasmid pBR322 (4362 base pairs, molecular weight about $3 \times 10^{\circ}$ ) to determine the yield of single strand breaks (ssb) and double strand breaks (dsb) as a consequence of the peroxyl free radicals formed by thermal decomposition of an azo-compound ABAP (or AAPH). The effect was compared to that caused by gamma irradiation. One ssb transforms a DNA molecule of the CC form to the nicked circular (NC) form, whereas one dsp produced either directly or from random coincidence of ssb's transforms DNA of the CC as well as NC form to linear DNA molecules (LI form). We separated these formes on agarose gel electrophoresis and quantitated their proportions on the basis of ethidium bromide fluorescence.

In addition to the mere strand breaks, we have probed the peroxyl free radical- and irradiation-treated DNA by $E$. coli endonuclease III (endolin), which removes several forms of damaged nucleoside bases, presumably most of them thymine derivatives. Endolli functions also as an AP-endonuclease, inducing strand breaks in the sites of removed bases.

Our experiments demonstrated a time-dependent induction of ssb's and dsb's, when DNA was incubated with ABAP. This effect could be inhibited by Nitecapone (OR-462), which is known to be a potent peroxyl radical scavenger.

We noticed that $35 \mathrm{mM}$ ABAP produced peroxyl radicals at the rate of $0.9 \mathrm{nmol} / \mathrm{min}$ and they induced in 5 min approximately as many ssb's and dsb's as did $30 \mathrm{~Gy}$ of gamma irradiation. EndoII sensitive sites were detectable after both types of treatments. The ABAPinduced strand breakage could partially be prevented by $27 \mu \mathrm{M}$ Nitecapone. We conclude that the present model is suitable for quantitative assessment of oxidative DNA lesions, and may be applicable to the assessment of environmental DNA damage as well. 
"Cellular Responses to Environmental DNA Damage"

CHEMICAL REACTIVITY, INTERSTRAND CKOSS-LINKING AND DNA SEQUENCE SPECIFICITY OF BIS(PLATINUM) COMPLEXES CONTAINING ONE AND TWO MONODENTATE PLATINUM ATOMS. Philio Wus, Ben Van Houtenat, and Nick Farrell". College of Medicine, Deparments of Biochemistry", Pathology" and Chemistrye, Vermont Regional Cancer Center, University of Vermont

Cisplatin (cis-DDP) and its derivatives have been used in high-dose therapy and combination therapies against a wide-range of tumors, including testicular and ovarian carcinomas. Despite the utility of these drugs, resistance significantly limits their use clinically. In an attempt to overcome this resistance problem and increase the effectiveness against a wider range of tumors, we have synthesized a novel series of bis(platinum) complexes containing two coordination spheres (NAR 17: 9719-9733, 1989). [(trans-PtCl $\left.\left.\left.\left(\mathrm{NH}_{3}\right)_{2}\right)\right] \mathrm{H}_{2} \mathrm{~N}\left(\mathrm{CH}_{2}\right)_{4} \mathrm{NH}_{2}\right] \mathrm{Cl}_{2}(1,1 / t, t)$ and [ cis$\left.\left.\mathrm{PtCl}_{2} \mathrm{NH}_{3}\right\} \mathrm{H}_{2} \mathrm{~N}\left(\mathrm{CH}_{2}\right)_{4} \mathrm{NH}_{2}\right)(2,2 / c, c)$ were shown to have activity against cisplatin resistant cells (L1210/cis-DDP resistant cells), although $(1,1 / \mathrm{t}, \mathrm{t})$ has a lower resistance factor (Biochem 29: 9522-9533, 1990). In the present study the rates of reaction of various bis(platinum) complexes with defined DNA sequences were investigated. The binding of [ (trans-PrCl $\left.\left(\mathrm{NH}_{3}\right)_{3}\right)-\mathrm{H}_{2} \mathrm{~N}\left(\mathrm{CH}_{2}\right)_{4} \mathrm{NH}_{2}$ - (trans$\left.\left.\mathrm{PtCl}\left(\mathrm{NH}_{3}\right)_{2}\right)\right] \mathrm{Cl}_{3}(1,0 / \mathrm{t})$ (an analogue containing only a single monodentate coordination sphere) was compared to the $1,1 / \mathrm{t}, \mathrm{i}$ compound and cisplatin and diethylenetriamineplatinum (DIEN). For comparison the $1,1 / t, t$ compound and cisplatin are displayed. The kinetic constants of inital binding of these various compounds were compared as was the effect of

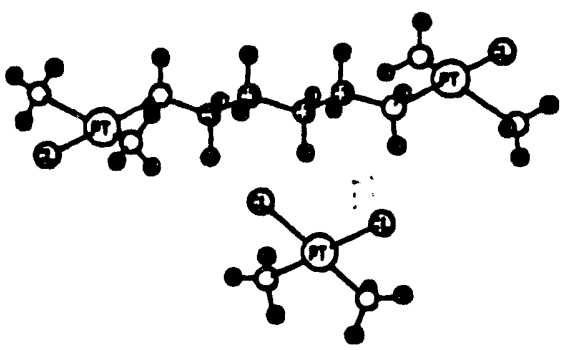
different nucleotides flanking the target guanine. The self-complementary oligonucleotides 5'ATATAT(N,)ATATAT-3' and 5'-ATATATAT $\left(\mathrm{N}_{2}\right)$ ATATATAT-3', where $\mathrm{N}_{4}=$ GGCC, GCGC, CCGG, or CGCG and $\mathrm{N}_{2}=\mathrm{GC}$ or CG, were used. The reactions were followed by denaturing poly-acrylamide gel electrophoresis and HPLC. The second-order rate constants for the binding of the 1,0 analogue to oligonucleotides containing $N_{4}=G G C C$ and $G C G C$ have been determined. For $N_{4}=G G C C, k=1.8 \times 10^{2} M^{-1} s^{-1}$ and $k=3.8 \times 10^{1} \mathrm{M}^{-1} \mathrm{~s}^{-1}$ for the $3^{\prime}$ and $5^{\prime}$ Guanines, respectively. The reactivity of the platinum compounds for oligonucleotides containing N4-GGCC, was $1,1 / 4,>1,0 / t>$ DIEN > cisplatin. It was also found that the reaction was inhibited by high $\mathrm{NaClO}_{4}$. A two-step mechanism for the reaction of bis-platinum compounds to DNA is proposed incorporating the coordination with the bases, hydrophobic effects of the diamine chain, and electrostatic effects as evident by inhibition by high salt. The electrostatic effects of the flanking sequences on reactivity is also comme.tted upon. This work was supported by ASC grant CH-463. 
Removal of Psoralen Photoadducts within the Amplified DHFR Domain in the CHO B11 Cell Line. Eelix J. Baker Ángel L. Islas and Philip C. Hanawalt. Department of Biological Sciences, Stanford University, Stanford, CA 94305-5020.

We have examined the rate and extent of removal of $4^{\prime}$-hydroxymethyl-4,5',8trimethylpsoralen (HMT) crosslinks and crosslinkable monoadducts from restriction fragments within the amplicon containing the dihydrofolate reductase (DHFR) gene in Chinese hamster ovary $B_{11}$ cells using the technique developed by Vos and Hanawalt (Cell 50:1789-1799, 1987). The rate and extent of removal of HMT crosslinks were significantly different in an actively transcribed fragment compared to a non-transcribed fragment of similar size. We found rapid loss of HMT crosslinking from the $14 \mathrm{~kb} \mathrm{Kpa} \mathrm{I} \mathrm{fragment} \mathrm{that}$ spans the 5' half of the DHFR gene: approximately $80 \%$ of the HMT crosslinks were removed in 8 hours. This is in agreement with the results reported by Vos and Wauthier (MCB 11:2245-2252, 1991). However, few crosslinks were removed in 8 hours from another $14 \mathrm{~kb}$ Kpn I fragment whose $5^{\prime}$ end ir, approximately $7 \mathrm{~kb}$ downstream from the DHFR transcription unit. This fragment is not uranscribed but includes a putative replication initiation site (Anachkova and Hamlin, MCB 9 :532-540, 1989). Even in 24 hours, only about $50 \%$ of the crosslinks had been removed from this fragment. On the other hand, both the rate and extent of removal of crosslinkable HMT monoadducts were similar in the two fragments: about 50\% of the crosslinkable monoadducts were removed in 24 hours from each fragment. This result not only differs from that observed for HMT crosslinks but also from the previously published reports for UV-induced cyclobutane pyrimidine dimers which are efficiently removed from the DHFR fragment but not from the non-transcribed downstream fragment (Ho et al., MCB 9:1594-1603, 1989). However, the similar removal of monoadducts from these two fragments is similar to that previously reported for aminoflourene adducts (Tang et al., JBC 254:14455-14462, 1989) and implies that the processing of some bulky adducts may not follow the paradigm for the processing of UV induced pyrimidine dimers. Preliminary evidence suggests, however, that monoadducts formed in the bulk of the genome are removed at a slower rate than from either of these specific sequences. Little or no overall repair was observed up to 8 hours at which time about $20 \%$ of the adducts had been removed; within 24 hours only about $35 \%$ of the adducts were removed from the genome overall. These results suggest that HMT crossliniks are more efficiently removed from actively transcribed sequences than from non-transcribed sequences, but that crosslinkable monoadducts are repaired at the same rate and to the same extent regardless of the transcriptional state of the sequence. 
Cellular Responses to Environmental DNA Damage

UV-Induced DNA Damage and Repair of a Yeast Minichromosome with a Galactose-Inducible Gene. Jirair Bedoyan†, Ranjan Gupta and Michael J. Smerdon, Department of Biochemistry and Biophysics, Washington State University, Pullman, WA 99164 4660 U.S.A.

Yeast minichromosomes are useful model substrates for studying various aspects of DNA damage and repair in eucaryotic cells. We are studying transcription, UV-induced DNA damage and cyclobutyl pyrimidine dimer (CPD) repair of a $4.3 \mathrm{~kb}$ multi-copy minichromosome in Saccharomyces cerevisiae called YRpSO1. The stability and positions of nucleosomes on this minichromosome has been studied in detail by S. Omari and F. Thoma (ETH-Honggerberg, Zurich; unpublished results). YRpSO1 has two functional genes: 1) the URA3 gene with its normal promoter replaced with the strong GAL1-10 promoter, and 2) the constiutively expressed HIS3 gene essential for maintaining the plasmid in his3-mutant yeast cells. URA3 expression is increased more than 100-fold when cells are switched from glucose to galactose-supplemented minimal medium. Northern analysis also indicates that 3 to 4 transcripts are made at much lower frequency from YRpSO1 in addition to the URA3 and HIS3 mRNAs when cells are grown in glucose or galactose-supplemented minimal medium. Iradiating intact cells with $254 \mathrm{~nm}$ UV-light yields $8.11 \times 10^{-6} \mathrm{CPD} / \mathrm{bp} \cdot \mathrm{Jm}^{-2}$ in YRpSO1. Surprisingly, examination of the average CPD repair of the entire plasmid, by measuring the fraction of Form I molecules resistant to T4 endonuclease $V$ after varying repair times, shows little difference in the repair-efficiency of YRpSOl when cells are switched from glucose to galactose-supplemented medium. However, the template strand for URA3 mRNA constitutes only about $12 \%$ of the total plasmid DNA, and the affect of enhanced transcription of URA3 on the efficiency of repair could be missed using this assay. Therefore, to provide better resolution of the repair rate in the URA3 domain, YRpSO1 was cut by restriction enzymes into two approximately equal fragments (one containing URA3 with the GAL1-10 promoter and the other containing the HIS3 gene). The UV-dose response of YRpSO1 irradiated in vitro shows no significant difference in the CPD yield (CPD/base. $\mathrm{Jm}^{-2}$ ) between these fragments. This is in agreement with predictions made by computer of potential UV-photoproduct forming sites. With an average of one CPD/plasmid in intact cells, these results suggest that only $-11 \%$ of YRpSO1 molecules in a given population would have a CPD on the template strand of URA3 mRNA. Experiments are currently underway to investigate CPD repair in each strand of the two fragments of YRpSO1, before and after galactose induction, to examine the effect of increased transcription of URA3 on the repair of these different domains. TPresent address: Carcinogenesis Laboratory-Fee Hall, Department of Biochemistry, Michigan State University, E. Lansing, MI 48824-1316 U. S. A. 
DNA EXCISION REPAIR IN XERODERMA PIGMENTOSUM GROUP C CELLS IS DEPENDENT ON TRANSCRIPTION. M. Camean and D.J. Hunting. Universite de Sherbrooke, Sherbrooke, Quebec, Canada.

Cyclobutane dimers are repaired more rapidly in several transcriptionally active genes than in the overall genome of cultured mammalian cells. This preferential repair appears to be limited to the transeribed strand both in mammalian cells and in E. coli, suggesting little or no role for chromatin accessibility. To determine if transeription is required for repair, we have used alphaamanitin to inhibit transcription by RNA polymerase II in UV-irradiated normal human fibroblasts, and in xeroderma pigmentosum group C (XP-C) cells. We find that alpha-amanitin has only a minor effect on either repair synthesis or incision in normal cells, at either early or late times of repair, but almost completely inhibits both processes in XP-C cells. Inhibition of protein synthesis with cycloheximide has no effect on repair in either cell type. The distribution of repair synthesis mesured among DNA sequences of different complexity (Cot analysis) demonstrates that repair occurs in all classes of DNA sequence in both normal and XP-C cells. Thus, the functional UV repair pathway in XP-C cells is dependent on transeription, even though repair also occurs in highly repetitive, non-transcribed sequences. The small effect of alpha-amanitin on repair in normal human fibroblasts suggests that the majority of repair events are independent of transcription, even at early times of repair. Supported by the MRC of Canada. 
Deficient repair of UV-induced cyclobutane pyrimidine dimers in mammalian ribosomal RNA genes. Ered C. Chriatians and Philip C. Hanawalt, Department of Blological Sciences, Sianford Univeraity, Stanford, CA, 94025-5020, U. S. A.

Mounting evidence suggests that the preferential repair of the transcribed DNA strand in expressed genes in mammalian cells is coupled to transcribing RNA polymerase II. Our finding that a-amanitin abolishes the strand-specific repair of UV-induced cyclobutane pyrimidine dimers (CPD) in the dihydrofolate reductase (DHFR) gene favors the model linking strand-specific repair to pol II transcription. However, little is known about the repair of rDNA, the genes encoding ribosomal RNA and transcribed by RNA polymerase I. One study (Vos and Wauthier (1991), Mol. Cell. Biol., 11, 2245) has indicated little repair of psoralen adducts in rDNA. However, the strong sequence conservation of rDNA suggests that mutation-inducing lesions are somehow repaired.

We are studying the fate of CPD in rDNA in Chinese hamster ovary (CHO) B11 cells. Restriction mapping has revealed intraspecies polymorphism, probably due to differences in the nontranscribed spacers separating rDNA repeats. We analyzed gene- and strand-specific CPD induction and removal from a $20 \mathrm{~kb}$ Pst I fragment which spans both the 185 and $28 S$ ribosomal genes. Only about one-third as many CPD were induced in rDNA relative to the DHFR gene, a finding attributable to the high G+C content of IDNA. No CPD removal occurred from either strand of either the 185 or 285 gene within 24 hours in cells UV-irradiated with either 10 or $20 \mathrm{~J} / \mathrm{m}^{2}$. Within the same period $80 \%$ of the CPD were removed from the transcribed strand of the DHFR gene.

We conclude that CPD are not removed from the ribosomal RNA genes in CHO cells. How then is the rDNA sequence conserved? Perhaps a small subset of these iterated genes is repaired. If the repair of rDNA is dependent upon its transcription, then the nucleolus, the subnuclear comparment within which pol I transcription occurs, should be the site of such preferential repair. We have attempted but were unable to effectively separate the rDNA in aucleoli from non-nucleolar rDNA. Alternatively, perhaps CPD are not repaired but: circumvented by recombination or replicational bypass pathways. These possibilities are currently under investigation. 


\section{CELLULAR RESPONSES TO ENVIRONMENTAL DNA DAMAGE}

GENE SPECIFIC REPAIR IN DRUG RESISTANCE Michele $R$. EVans*, Khew-Voon Chin**, Wei.Ping Zhen*, Michael M. Gottesman**, Vilhelm A. Bohr*; Laboratory of - Molecular Pharmacology*, Laboratory of Molecular Bjology**, National Cancer Institute Bethesda, Maryland 20892 U.S.A.

We have long been interested in the correlation between transcription, gene specific repair and mechanisms of drug resic ance. We have studied gene specific repair of UV. induced cyclobutane pyrimidine dimers as well as cisplatin intrastrand adducts and interstrand crosslinks in human cervical cancer KB cell lines with varying levels of expression and amplification of the multidrug resistance gene, MDR1. These cell lines were selected so that gene specific repair could be studied in related cell lines with different levels of gene expression, gene amplification and drug resistance possibly allowing us to correlate DNA repair with levels of transcription and drug resistance.

The KB 3-1 parental cell line has no amplification of the MDR1 gene and low levels of MDR1 mRNA expression. The KB 8-5 cell line has no amplification of the MDR1 gene but has elevated levels of MDR1 mRNA expression. The KB C-1 cell line is 10 fold amplified for the MDR1 gene and markedly elevated levels of MDR1 mRNA expression. KB 8-5 and C-1 cell lines demonstrate significant levels of resistance to colchicine, doxorubicin and vinblastine when compared to the parental KB 3-1 line. Repair was studied in the active DHFR gene, three fragments of the MDR1 gene and c-myc as well as in the inactive deltaglobin and MDR2 genes. Strand specific riboprobes were also constructed to further evaluate the strandedness of repair.

Interesting differences in the efficiency of gene specific repair of UV-induced dimers were observed between the KB cell lines for all three fragments of MDR1 studied, most likely related to levels of gene expression. However, significant levels of repair were also observed for the inactive MDR2 gene perhaps linked to the level of MDR1 mRNA expression which is $30 \mathrm{~kb}$ upstream from the MDR2 gene. In other experiments, we have found that human A2780 cisplatin resistant cell lines repair cisplatin interstrand crosslinks more efficiently than the parental cisplatin sensitive cell line. However, no differences in the repair of intrastrand adduct repair were noted in these cell lines. This has led us to speculate that there may be a correlation between the repair of interstrand crosslinks and drug resistance. We are now investigating the repair of cisplatin intrastrand adducts and interstrand crosslinks in the KB cell lines to determine if there is a direct correlation with levels of gene expression or expression of the multidrug resistant phenotype. 
CELIULAR RESPONSES TO ENTIROMLENTAI DNA DAYAGE

AIMERATIOA II DEA CROSSITIRING AND SEOUENCE SELETIVITY OF A SERIBS OF AZIRIDINYLBEIZOQUINONES APTER ENZYALTIC REDOCTION BY DTDIAPBORAsE. Chong-Soon Iee ${ }^{2}$, John A. Hartley ${ }^{2}$, Mark D. Berardini², John Butlex", David Siegel“, David Ross" and Xeill H. Gibson'. 'school of Pharmacy and Comprehensive Cancer Center, University of Southern California, Los Angeles, CA 90033. 'Department of Oncology, University College and Middlesex School of Medicine, 91 Riding House streat, London WIP 8BT. 'Paterson Institute for Cancer Research, Christie Hospital and Holt Radium Institute, Manchester H20 9BX. "Sihool of Pharmacy, University of Colorado, Boulder, CO 80309 .

DT-diaphorase (DTD) modiated reduction of a series of 2,5-bis substituted-3,6-diaziridinyl-1,4-benzoguinones was found to increase the level of DNA Interstrand crossinining (ISC) formed at neutral pH with an enhancement observed as the pH was decreased to 5.8. The analogs used were: symmetrically alkyl substituted carbamoyl ester analogs of AzQ, 3,6-diazridinyl-1,4-benzoguinone (DZQ), the 2,5-methyl derivative (MeDZQ) and $a$ 2,5hydroxyethylamino analog (BzQ). At pH 5.8 the leivel of DWA ISC induced by anzymatic reduction was as follows DZQ > MeDzQ $>$ methyl (D1) > n-propyl (D3) > ethyl (A2Q, D2) > n-butyl (DS) > sec-butyI (D7) > 1-propyl (D4) > 1-butyl (D6). A similar trend was observed at pH 7.2. The level of DNA ISC induced by BZQ, which is not a substrate for DTD, was not increased by enzymatic reduction. Dicumarol, a known inhibitor of DTD was capable of inhibiting the DNA ISC induced by these quinones upon enzymatic reduction. MeDzo and DZQ rnacted with guanines, as measured by Maxam and Gilbert sequencing, with a sequence selectivity similar to the nitrogen mustard class of antitumor agents. Enzymatic reduction of DZQ and MeDzQ by DTD was found to alter their sequence selective alkylation. Reduced DZQ showed enhanced guanine alkylation in 5\%GC-3' seguences and new sites of adenine alkylation in $5^{\prime}-(A / T) A-$ 3' eequences. Reduced HeDzQ only showed new sites of adenine alkylation at $5^{\prime}-(\mathrm{A} / \mathrm{T}) \mathrm{N}^{\prime}-3^{\prime}$ sequences but no enhancement of guanine alkylation. The new sites of adenine alkylation were found to be inhibited in the presence of magnesium and rapidly converted into apurinic sites. Chemical reduction of DZQ by ascorbic acid altered the sequence selective pattern of alkylation in a manner similar to that observed for enzymatic reduction. Ascorbic acid was unable to reduce MeDZQ. These data show that DTD mediated reduction can effect the sequence selectivity of alkylation and DNA interstrand crossilink induction by aziridinylbenzoguinones. In conclusion, this data supports our contention that DTD 18 an important enzyme in the intracellular aerobic activation of a series of aziridinylbenzoguinones to DNA reactive and cytotoxic species. 


\section{Cellular Responses to Envirommental DNA Damage}

Genotoxic carcinogens preferentially alter the expression of inducible genes relative to constitutive genes in vivo. Joshua W. Hamilion, Jennifer McCaffrey, Rosemary M. Caron, Claudine A. Louis, Melinda D. Treadwell, Nicole S. Baptiste, Steven R. Hunt and Kristen A. Doherty. Deparment of Pharmacology and Toxicology, Dartmouth Medical School, Hanover NH 03756.

Our laboratory is interested in whether carcinogen-induced DNA damage is "targeted" to specific genes or gene regions in vivo. It is not yet possible with current techniques to directly measure carcinogen-induced DNA damage to individual genes in vivo at physiologically relevent exposures. Therefore, as an indirect measure of whether targeting occurs at the gene level, we have examined whether carcinogens differentially alter the expression of individual genes. We have measured the effects of model genotoxic carcinogens which induce crosslinks (chromium(VI), mitomycin C), bulky lesions (2acetylaminofluorene, benzo[a]pyrene, 7,12-dimethylbenz[a]anthracene, aflatoxin $\mathrm{B}_{1}$ ), or simple alkylations (methyl methanesulfonate, ethyl methanesulfonate, methylnitrourea, ethylnitrourea) on the expression of several constitutively expressed ( $\beta$-actin, transferrin, albumin) and drug-inducible genes (ALA synthase, cytochromes PB, P450 and MC4 P450, $P E P C K$ ) in a simple in vivo system, the 14 day chick embryo liver. Each agem was tested at the maximum tolerated dose over a $24 \mathrm{hr}$ period corresponding to the period of maximal DNA damage and repair by each compound. None of the agents tested significantly altered the expression of the constitutive genes over this period, whereas all of these agents altered either basal and/or drug-inducible expression of the inducible genes. However, the direction and magnitude of the individual effects on expression of the inducible genes were both geneand agent-specific. For example, chromium(VI) increased basal ALA synthase and $\mathrm{PB}_{1}$ P450 expression and decreased their drug-inducible expression, whereas mitomycin C induced the opposite effects on ALA synthase and had no effect on PB 1 P450 expression. There were also some general trends observed. For example, all of the agents which induce bully lesions increased the drug inducibility of ALA synthase, whereas all of the simple alkylating agents suppressed the drug induction of this gene. Although there were qualitative and quantitative differences, in all cases the time course for the effects of each carcinogen on gene expression were strongly correlated with the time course for carcinogen-induced DNA damage caused by that agent. The lack of effect of these carcinogens on either total RNA symthesis or on the specific expression of the constitutive genes argues that these effects do not reflect a general change in RNA transcription. Similarly, the gene- and agent-specific changes observed in inducible gene expression argue that these carcinogens are not targeting a gene; al induction pathway or a general transcription factor common to all of the inducible genes. These results are consistant with the hypothesis that DNA damage by chemical carcinogens is non-random at the gene level. Our results also suggest that a sub-set of active genes. i.e., inducible genes, may be hyper-sensitive to DNA damage and that effects on their expression may differ depending on the specific type of DNA lesion induced. Supported by grants from the National Institutes of Health (CA49002 - JWH; ES07104 RMC, JM, CAI), the Hughes Foundation (NSB), the American Cancer Society (JFRA-323 - JWH) and the Intemational Life Sciences Institute (JWH). 
A-48 INITIAL FORMATION AND BNZYMATIC ELIMINATION OF O6-RIRYLGUANINE IN DEFINED SEGMENTS OF GENONIC DNA

Institute of Cell Biology (Cancer Research), West German Cancer Center Essen, University of Essen Medical School, gufelandstr. 55, D-4300 Essen 1, Germany.

Much attention is recently being locused on the intragenomic distribution of specific DNA lesions induced by endogenous and/or exogenous DNA-reactive agents and their potential topnselective formation and enzymatic elimination. The premutagenic lesion $0^{6}$ alkylguanine is of major importance due to the existence of alkylating agents in the normal human environment as well as one of several mechanisms of action of some anti-cancer agents. Nevertheless, its intragenomic distribution and toposelective elimination is poorly characterized until now. Using our immunoaffinity procedure developed recently (Bochleitner et al., 1991), we are now quantifying O-ethylation adducts in specific DNA segments of the eukaryotic genome. We have examined formation and repair of $0^{6}$-ethylguanine after a pulse-treatment with N-ethyl-Nnitrosourea in non-transcribed and transcribed genes fand related pseudogenes) of two rat hepatoma cell lines exhibiting different DNA repair capacities. In addition, experiments are performed in cells pre-treated with $0^{6}$-benzylguanine to inhibit the repair protein $0^{6}$-alkylguanin-DNA-alkyltransferase.

Reference:

Bochleitner, K., Thomale, J., Nikitin, A. Yu,, Rajewsky, i. F. (1991) Monoclonal antibody-based, selective 1solation of DNA fragments containing an alkylated base to be guantified in defined gene sequences. Nucl. Acids Res. 19, 4467-4472. 
"Cellular Repsonses to Environmental DNA Damage"

\begin{abstract}
ANALYSIS OF DNA DAMAGE AND REPAIR IN SPECIFIC DNA SEQUENCES USING THE POLYMERASE CHAIN REACTION. Douglas P. Kalinowski and Ben Van Houten. Department of Pathology, University of Vermont, Burlington, VT.
\end{abstract}

The polymerase chain reaction (PCR), an in vitro method for the amplification of specific regions of DNA, represents a powerful new technology for the study of DNA damage and repair. Theoretically, any DNA lesion that blocks Taq polymerase can be measured in this assay. The lesion frequency per segment of the genome can be determined for a given dose of DNA damaging agent by quantifying the amount of amplification of an undamaged template and a template containing DNA lesions and using the Poisson equation. PCR can thus measure the lesion frequency and subsequent repair of any DNA damaging agent which blocks Taq polymerase in any DNA segment for which flanking sequences are known. We used this approach to determine the lesion frequency of cisplatin-DNA adducts and UV-induced photoproducts in a 2.3 kilobase pair (kbp) segment of mitochondrial DNA and a $2.6 \mathrm{kbp}$ segment in the DHFR gene in mouse L1210 cells following exposure to biologically relevant doses of the above mentioned DNA damaging agents. In both the DHFR gene and mitochondrial DNA, UVinduced damage ( 0 to $80 \mathrm{~J} / \mathrm{M}^{2}$ ) decreased amplification in a dose dependent manner. Calculated lesion frequencies increased linearly with dose, though slightly less for the the DHFR gene than for mitochondrial sequences. Based on the slope of this increase, the lesion frequency was 0.13 lesions $/ 2.3 \mathrm{kbp} / 10 \mathrm{~J} / \mathrm{M}^{2}$ in the mitochondrial DNA, and 0.1 lesions $/ 2.6 \mathrm{kbp} / 10 \mathrm{~J} / \mathrm{M}^{2}$ in the $D H F R$ gene. With cisplatin, amplification was decreased in a dose dependent manner from 0 to $150 \mathrm{uM}$ cisplatin in the DHFR gene. The calculated cisplatin-DNA lesion frequency, also increasing linearly with dose, was 0.043 lesions $/ 2.6 \mathrm{kbp} / 10 \mathrm{uM}$ cisplatin. In the mitochondrial sequences, however, cisplatin did not produce a significant decrease in amplification until over $100 \mathrm{uM}$, and the lesion frequency was significantly less than for the DHFR gene. At $150 \mathrm{uM}$ cisplatin, the lesion frequency was 0.27 lesions $2.6 \mathrm{kbp}$ segment in the mitochondrial DNA, and 0.67 lesions/2.6 kbp segment in the DHFR gene. This result is contrary to previous studies which have shown mitochondrial DNA to receive greater damage than nuclear DNA when exposed to a variety of chemical agents. Data will also be presented on the kinetics of DNA repair following UV and cisplatin damage in mitochondrial DNA and the DHFR gene in mouse L1210 cells. This work was supported by an NIH FIRST CA50681. DPK is supported by Environmental Pathology Training Grant ES07122-09. 
Cellular Responses to Environmental DNA Damage.

Gene Specific Repair of Nitrogen Mustard Crosslinks in Hamster and Human Cells.

Elorence Larminat, Weiping Zhen and Vilhelm A. Bohr, Laboratory of Molecular Pharmacology, National Cancer Institute, Bldg. 37, Rm. 5C-25, NIH, Bethesda, MD 20892, USA.

Nitrogen mustards are a group of chemotherapeutic alkylating agents which react with the DNA in a sequence specific manner. Their biological effects may depend upon preferential reaction at certain genomic regions. Recent studies in our laboratory showed that some $\mathrm{N7}$ allylations are preferentially located and repaired in specific gene regions.

We have examined the formation and removal of nitrogen mustard interstrand crosslinks in specific genes (DHFR, non-coding region, c-fos protooncogene) in CHO cells. The crosslinks were detected by a denaturation-renaturation procedure followed by gel-electrophoresis and Southern analysis. We found that nitrogen mustard crosslinks were repaired faster in active genes as compared to non-coding regions, when the CHO cells were treated with a low concentration of allylating agent (25uM). Howewer, the rates of nitrogen mustard crosslink removal from active and inactive genes were similar, when the CHO cells were treated with higher.doses of the chemotherapeutic agent (100uM and 300uM). The preferential repair of nitrogen mustard crosslinks may be dependant upon the frequency of induced crosslinks in different genomic regions. Such results are consistent with saturation of the gene specific repair of nitrogen mustard crosslinks. Moreover, recent data demonstrate that there is no preferential repair of cisplatin-induced interstrand crosslinks Jones et al. , J. Biol. Chem. 266, 7101-7107, 1990). Our studies suggest that different types of crosslinks may be repaired by different mechanisms.

We are currently evaluating the repair of nitrogen mustard crosslinks in specific genes (DHFR, deltaglobin) in human fibroblasts and in the c-myc oncogene in a human neuroendocrine colon carcinoma cell line to further describe the mechanism(s) involved in the gene specific repair of crosslinks. 
NOVEL PATTERN OF POST- $\gamma$ RAY DNA REPLICATION IN RADIORESISTANT FIBROBLAST STRAINS FROM AFFECTED MEMBERS OF A CANCER-PRONE FAMILIY WITH LI-FRAUMENI SYNDROME, Rarmik Mirzayans and Malcolm C. Paterson, Molecular Genetics and Carcinogenesis Laboratory, Department of Medicine, Cross Cancer Institute, Edmonton, Alberta T6G 1Z2, Canada.

Dermal nontransformed fibroblast strains, cultured from affected members of a family predisposed to diverse mesenchymal and epithelial malignancies including several of suspected radiogenic origin, have been reported to display both increased resistance to the lethal effects of $\gamma$ radiation and coactivation of c-raf-1 and c-myc protooncogenes. In addition, this kindred, like others with the dominantly inherited LiFraumeni cancer family syndrome (LFS), is known to carry a germ-line mutation in the p53 tumor suppressor gene. We have now linked the radioresistance (RR) trait exhibited by the LFS strains to an abnormal pattern of post-y ray DNA replicative synthesis, as monitored by the rate of radiolabelled thymidine incorporation into DNA during postirradiation cell incubation. Specifically, the magnitude of the initial inhibition of DNA synthesis induced by the radiation treatment and the interval before its subsequent recovery were both significantly greater in RR cells compared to normal controls. Moreover, the post-recovery DNA replication rate was markedly elevated and was maintained much longer in RR than in normal cells. This altered pattern of DNA synthesis was seen in all four RR strains (but not in spousal control strains displaying normal clonogenic survival after $\gamma$ rays), leading us to propose that its uccurrence may provide extra time frs the repair of potentially deleterious DNA lesions which might otlerwise hamper INA replication and cell division. In support of this hypothesis, RR cells proved to be hypomutable upon radiation exposure in that mutants resistant to the antimetabolite 0 -ibioguanine were induced by $\gamma$ rays at a 4 -fold lower frequency in $R R$ than in normal strains. Given the unexpected convergence in $R R$ cells of (i) documented anomalies in recessive (p53) and dominant (c-raf-1 and c-myc) proto-oncogenes, the latter two genes encoding key components of mitogenic signal transduction pathways, and (ii) abnormal DNA-labelling kinetics after $\gamma$ irradiation, it is tempting to speculate that the transitory shut down of DNA replication in human cells following radiation exposure is controlled by a mechanism that may utilize elements of the signal transduction circuitry governing normal cell growth and development. (Supported by Medical Research Council and National Cancer Institute of Canada and Alberta Heritage Foundation for Medical Research) 


\section{Mapping of UV-induced Adducts and their Repair Rates at the DNA}

\section{Sequence Levei}

GerdP. Pfeifer, Régen Drouin, Shu-Wel Gao, Arthur D. Riggs, and Gerald P. Holmquist Department of Biology, Beckman Research Institute of the City of Hope, Duarte, CA 91010, U.S.A.

Cyclobutane pyrimidine dimers and pyrimidine (6-4) pyrimidone photoproducts [(6-4) photoproducts], the major base alterations found after ultraviolet (UV) irradiation of DNA, are both involved in UV-induced mutagenesis and carcinogenesis. We have adopted the ligation-mediated polymerase chain reaction (LMPCR) to allow detection of these adducts in mammalian single-copy genes at the DNA sequence level. After UV irradiation of cells, DNA is isolated and either chemically cleaved at (6-4) photoproducts with hot piperidine or enzymatically cut at the cyclobutane pyrimidine dimers using T4 endonuclease $V$ followed by photolyase. These treatments change the photoadducts into ligatable DNA strand breaks. Gene specific fragments are then amplified from total genomic DNA by use of LMPCR. This approach is a very sensitive method for detecting rare DNA breaks and displaying these as a sequencing gel patterm. It presents a novel method for in vivo mapping of DNA adducts. Analysis of the human phosphoglycerate kinase (PGK-1) gene's promoter has shown that the rate of formation of photoadducts is: i) very high at specific dinucleotides, ii) dependent on the nearest neighbor bases, and iii) influenced by the binding of transcription factors. The frequency of cyclobutane dimers and (6-4) photoproducts at specific dipyrimidines within transcription factor binding sites is enhanced by up to 25-fold, presumably by presence of a local DNA conformation that is favorable for dimer formation. Since we can map cyclobutane dimers at UV doses below $20 \mathrm{~J} / \mathrm{m}^{2}$, we have begun to investigate the DNA repair process at the DNA sequence level. Instead of studying an average repair rate of the genomic DNA for specific lesions, the repair rate of each nucleotide position is being analyzed. 


\section{Cellular Responses to Environmental DNA Damage}

Siructure and Function of Origins in Eukaryotic DNA Replication. Gerald B Price, Wu Curile, Claude Lamoureux, Paula Friedlander, Michael A. McAlear, Christopher E. Pearson, Veronica Klein, and Maria Zannis-Hadjopoulos. McGill Cancer Centre, McGill University, Montréal, Québec, Canada H3G 1 Y6

DNA fragments, which range from approximately 100 bp to $3 \mathrm{kbp}$ and contain eukaryotic origins of DNA replication have been obtained from monkey and human cells. Two of the most common features of these fragments which contain mammalian origins are that the DNA is AT-rich and has inverted repeats capable of forming cruciforms.

We have isolated monkey and human origins of DNA replication by three separate methods. The initial method of isolation was extrusion of early replicated DNA from replication bubbles of cells(CV-1, W/38) synchronized at the $G_{1} / S$ boundary with aphidicolin and released for a fow minutes into S-phase[Frappier \& ZannisHadjopoulos, Proc. Natt. Acad. Sci. 84:6668, 1987].

The second method was to screen a CDNA library (IMR90) for transcripts containing origins of DNA replication. Two cDNA clones which contain sequences which function as origins of DNA replication have been characterized as being AT-rich and containing inverted repeats, bent DNA, and DNA unwinding elements. Further studies of transcriptional effects upon DNA replication from these origins are in progress. Genomic clones are being isolated to do in vivo mapping of origin activity associated with these transcribed sequences.

The third method was to use antibody-affinity purification of cruciform-containing high molecular weight, negatively supercoiled DNA(CV-1, WI38, SW48, normal skill fibroblasts)[Bell et al., Biochim. Biophys. Acta, in press, 1991]. Our previous work, which demonstrated the effect of anti-cnuciform DNA specific antibody[J. Mol. Biol. 193:751, 1987; J. Biol. Chem. 264:334, 1989] on DNA replication in vivo [EMBO J. $7: 1837,1988]$, encouraged us to use that antibody to attempt affinity-purification of mammalian origins from genomic DNA. Nearly $50 \%$ of the fragments of DNA thus isolated can support autonomous replication(when cloned into bacterial plasmids) upon transfection into Hela cells. Using an in vitro system of eukaryotic DNA replication[C. Pearson et al. Biochim. Biophys. Acta, in press, 1991], we demonstrated that supercoiling of plasmids containing mammalian origins through the use of gyrase(i.e. thereby increasing the probability of extrusion of inverted repeats into cruciforms) enhances the level of replication products. Furthermore, inclusion of anticruciform antibody in the in vitro system results in the increase of DNA replication products by up to 2 orders of magnitude.

Athough we have analysed the sequence of nearly 40 origin-containing fragments, no common consensus sequences are universally found. The most common features relate to structure, AT-rich DNA(susceptible to many secondary structural alterations) and inverted repeats(capable of cruciform formation). We believe that the formation of DNA cruciforms represent important events of recognition and initiation of replication. We therefore hypothesize that the structure-function relationships which govern cruciform formation represent a fundamental focus of DNA replication modulation by transcription, DNA damage, and malignant transformation. : (Research supported by NSERC, NCl, Cancer Research Society, Inc. and MRC of Canada.). 


\section{Cellular Responses to Environmental DNA Damage}

Effect of AP sites on transcription by 77 RNA polymerase. Giselle Sanchez and Margaret D. Mamet-Bratley. Departement de biochimie, Université de Montreal, Montreal (Québec) H3C 3J7.

Apurinic and apyrimidinic (AP) sites are the most common spontaneous lesions in DNA and may play an important role in mutagenesis and carcinogenesis. AP sites act as strong blocks to the progression of different DNA polymerases; however, E. coli.RNA polymerase most often bypasses these lesions. The development of bacteriophage $T 7$ containing AP sites was studied in an $E$. coli double mutant deficient in exonuclease III and endonuclease IV (xth-nfo). Analysis of phage specific DNA and protein synthesis suggested that transcription by 77 RNA polymerase was the step of intracellular phage development most affected by AP sites. The effect of AP sites on RNA synthesis in vitro was examined using a plasmid containing a $T 7$ promoter. Increasing numbers of AP sites caused a progressive decline in RNA synthesis. The time course of RNA synthesis suggested that the T7 RNA polymerase was not permanently inhibited on a template containing AP sites. Polyacrylamide gel electrophoresis of the RNA product revealed only the full length transcript, thus indicating an efficient bypass of lesions by T7 RNA polymerase. 
Replication of an Active Gene in ov Irradiated CHO cells. Gractela spivak and Philip C. Hanawalt, Department of Blological sciences, stanford University, stanford CA 94305-5020, USA.

The mechanisms that allow DNA replication to occur in the presence of lesions are unknown several possibilities have been suggested, including lesion bypass and strand exchange. The combination of ultraviolet light as the damaging agent, and rodent cells in culture as the target, offer a good model system to study the distribution of lesions in the repilcation products because these cells remove cyclobutane pyrimidine dimers (CPD) selectively from expressed genes, and in particular, only from the transerlbed strands (Bohr et al, cell 40, 359-369, 1985; Madhani t al, coll 45, 417-423, 1986, Mellon et al, cell 51, 241-249, 1987).

In our studies, we compared the CPD content in the transcribed and non-transcribed strands of replicated and unreplicated equences of restriction fragments in the amplified DHFR (dihydrofolate reductase) locus of Chinese hamster ovary (CHO) B11 cel1s.

In these experiments, the cells were Incubated in the presence of BrdUrd after UV irradiation; the parental (II) DNA was separated from the replicated (IIL) DNA by isopyonic sedimentation in CsCl and then the $\mathrm{H}$ and $I$ strands were separated in alkaline Cscl gradients. We determined the fraction of a $14 \mathrm{~kb}$ kpnI fragment of the DHFR gene that was resistant to digestion by T4 endonuclease $v$, a CPD-specific enzyme. The initial frequency of dimers was similar for the transcribed and the non-transcribed strands. We found no elgniflcant differences in the repair of the parental DNA strands whether they had served as templates for replication or not: $-25 \%$ of the dimers remained in the transcribed strands while -708 remained in the non-transcribed strands after $24 \mathrm{hr}$. We detected no dimers in the daughter strands. These results suggest that the replication forks can wove through the damaged DNA in the absence of significant 1evels of repair or of etrand exchange.

We conclude that no preferential repair of CPD is correlated with replication in these cells.

(supported by NIH Grant CA44349). 
Involvement of Specific DNA Related Enzymes in Gene Specific DNA Repair. IInna Stevnner, Ruchuang Ding*, Mark Smulson*, Vilhelm A. Bohr. Laboratory of Molecular Pharmacology, National Cancer Institute, BIdg 37, Rm SC25, NIH, Betheada, Maryland 20892, Department of Biochemistry and Molecular Biology, Georgetown University, Washington, DC 20007.

We have used several aproaches in order to invertigate which enzymes are involved in gene specific DNA repair. We studied the effect of inhibitors of DNA polymerase alpha and delt (aphidicolin), ribonucleotide reductase (hydroxy urea), poly(ADP-ribose) polymerase (3aminobeanide), topoisomerase I (camptothecin), and topoisomerase II (VP 16 and merbarone). None of these inhibitors had any effect on the gene specific DNA repair of pyrimidine dimers in the dihydrofolate reductase (DHFR) gene of chinese hamster ovary (CHO) cells (Jones et al., Mutntion Research, in press). However, by inhibiting the two types of topoisomerase simultanecusly we are able to significantly inhibit the repair of pyrimidine dimers in the DHFR gene. These results therefore suggest that it is likely that topoisomerases are involved in gene specific DNA repair of pyrimidine dimeirs in CHO cells and that either topoisomerase can perform the necessary activity. This conclusion is supported by results obtained by the use of a sligthly different aproach: When a CHO cell line, which is deficient of topoisomerase I'activity is treated with a topoisomerase II inhibitor we also find significant inhibition of the gene specific DNA repair. The inhibition of repair of the'DHFR gene seems to be due to the inhibition of the repair on the preferentially repaired transcribed strand. The repair of the total genomic DNA is affected significantly less than the repair of the gene by the presence of a combination of a topoisomerase I and topoisomerase II inhibitor.

Our results suggest that there are enzymological differences between the repair of the overall genome and the repair in active genes. Gene specific repair of other types of damage such as cisplatin intrastrand adducts, cisplatin interstrand crosslinks, and alkylation damage by nitrogen mustard are not affected by the ropoisomrase inhibitors. Topoisomerases may therefore only be important in genespecific repair which involves relatively long repairpatches or simply in repair of adducts of a certain type.

An altemative aproach to get further insight into the involvement of specific enzymes in gene specific DNA repair is by studying the effect of inducible expression of antisense RNA on DNA repair. This method reduces the amount of protein rather than simply inhibiting activity of the enzyme which is becing studied. Poly(ADP-ribose) polymerase is thought to participate in DNA repair, and we are currently studying how gene specific DNA repair of alkylation damage by nitrogen mustard is affected by the induction of poly(ADP. ribose) polymerase antisense RNA in a stably transfected HeLa cell line. 


\section{Cellular Responses to Environmental DNA Damage}

PERSISTENT SINGLE-STRANDED REGIONS IN NEW LY-REPLICATED DNA FROM INDIAN MUNTJAC CELLS EXHIBITING DEFECTIVE UV-INDUCED POST-REPLICATION RECOVERY. Bernard W, Stewart ${ }^{1}$, Daniel $R$. Catchpoole 1, C. Stephen Downes2, Anderson Ryan2 and Robert T. Johnson'. 'Children's Leukaemia and Cancer Research Unit, Prince of Wales Children's Hospital, Sydney, N.S.W. 2031, Australia and 2CRC Mammalian Cell DNA Repair Group, Department of 20010g7, Cambridge University, Cambridge CB2 3EJ, Great Britain.

An Indian muntjac (Muntiacus muntjak) ceil line transformed by SV 40 (designated SVM) is hypersensitive to the cytotoxdc effects of UV light relative to another permanent Muntjac line (DM). This difference is not attributable to defective excision repair, but has been correlated with defective maturation of nascent DNA following irradiation (Pillidge, L. et al, Int. J. Radiat. Biol., 50:1 19-136, 1986). Using these lines, examination has now been made of replication-associated structural change in DNA by chromatography on benzoylated-DEAE cellulose. This procedure permits quantification of the proportion of DNA (in a sheared preparation) exhibiting single stranded character and measurement of the length of single-stranded regions. In the absence of damage, incorporation of $3 \mathrm{H}$-thymidine into DNA from both the Muntjac lines was immediately associated with structural change similar to that detected in replicating DNA from human cells (Stewart, B.W. et al, Exp. Cell Res., 192: 639-642, 1991). Two classes of single stranded regions were evident, viz. 'short' regions of approximately 200 nucleotides and a more diverse population exhibiting long' single stranded regions with a modal length of $1-4 \mathrm{~kb}$ which were associated with most newlyincorporated thymidine. In pulse-chase studies, the SVM line was distinguished by peristence of single stranded character for at least 2 hours after labelling. The effect was attributable to long single stranded regions. Structural difference between DNA isolated from SVM and DM cells was evident by radiolabelling 4 hours after 'release' from an aphidicolin inhibition of replication. Electrophoretic analysis also suggested defective maturation of DNA in the UV-sensitive line. Parallel studies have utilized an SVM-transfectant line (BT335), selected on the basis of reduced sensitivity to UV irradiation. Analysis of replicating DNA Irom these cells suggests structural change intermediate between that in SVM and DM cells. The findings indicate that post-replication. recoyery, evident in SVM cells after DNA damage, may be consequent upon a genetic defect associated with processing of newly incorporated polynucleotides into mature and structurally-integrated DNA 
Cellular Reaponses to Environmental DNA Damage

Replication of DNA Containing Cyclobutane Pyrimidine Dimers in the Unamplified DHFR Gene in Repair-proficient and Repair-deficient Chinese Hamster Ovary Cell Linee Kevin S. Sweder and Philip C. Hanawalt, Stanford University, Stanford, Californin 9430s5020

We present evidence that replication of UV-damaged DNA within a defined gene in mammalian cells is not facilitated by preferential repair of templates about to be replicated, nor is there preferential replication of damage-free templates over damaged templates. These conclusions are based upon measurements of the frequency of T4 condonuclease V sensitive sites ren raining 24 hours after UV irradiation in a 14kb KpnI fragment in either the transcribed or non-transcribed strand of the unamplified dihydrofolate reductase (DHFR) gene in both repair-proficient and repair-deficient Chinese hamster ovary cella. The frequency of cyclobutane pyrimidine dimers in the non-transcribed atrand of the replicated parental DNA template, eeparated from the BroUrd-labelled nasceat strand, was compared to that in the non-transcribed strand of the unreplicated parental strands and there was no significant difference found between them. Thus, replication of the DHFR gene did not enhance the the removal of dimers from the nontranseribed strand of that gene. We also found that dimers were rapidly removed from the transcribed strand of the DHFR gene whether it had replicated or not. Thus, passage of a DNA replication fork through the gene does not alter the transcription-dependent DNA repair of the sequence, ie, strand-specific repair. These results are consistent with the compartmentalization of replication and transcription to different locations within the nucleus. Confinement of repair enzymes to those regions where RNA polymerase II transcription is occurring may enable them to repair genes transcribed by RNA pol II but prevents their acting on domains (e.gn replicating regions) that would otherwise be a substrate for their action. 
REPAIR IN SPECIFIC OENES MOTATED DURING TUMORIGENESIS

Bonita G. Taffe, Michele K. Evans, Curtis C. Harris, Vilhelm A. Bohr, Laboratory of tluman Careinogenesis and Laboratory of Holecular Pharmecology, National Cancer Institute, Bethesda, XD 20892.

Curolnogenesis is a multistep process which has bean described in tumor model syateme to require multiple genotoxic events. One quastion concerning this process is whother altored DNA ropalr occurs in precureor colls, predieposing these cells to furthar mutations. In this study, we are using gene opecific DNA repair mothodology to examine the question of whether there is differential repaif in genes found to be activated in the oncogenic process. Repalr in the p53 gene la negative regulator of cell cyole prograsioion) is of interast due to the multiple tumor types which contain uutations in this gene. The lung is one organ in which tumors contain mutations in p53 are commonly found, therefore, in this study we are using several human lung tumor derived cell Iines as well as a human primary fibroblast control to assess the rates of repair of the P53 gone. Of the human tumor cell Iines under study, two express mutated protein products and one expresses the wild type protein. Other cellular genes which are beling studied are the myc gene, and DHFR. Preliminary lindings will be reported. 
Seguence-Specifle Yodification of Din by Bensola]pyrene Diol spoxide Deterenined by Inhibltion of Polymerase sctivities.

Brian D. Thral1', Mchael J. Smerdon ${ }^{2}$ and David I. Springerd. Battello Pacific Northwest Laboratory, Richland, WA $99352^{1}$ and washington state University, Department of Biochemistry and Blophysics, Pullman, wa $99164^{2}$.

Benzola]pyrene diol epoxide (BPDE) is a highly reactive metabolite of benzo[a]pyrene and forms a number of covalent adducts with DWA. Of these adducts, 85-95 are on the exocyclic nitrogen of deoxyguanine, resulting in a bulky lesion which interferes with the progression of DNA and RNA polymerases. We are using this phenomene to map the distribution of damage in plasmid DNA modified with BPDE in order to better understand the sequence-specific factors involved in DNA adduction. Replication of BPDE-modifled DWA with T7 DWA polymorase (Sequenase) consistently results in blockage of the polymerase at one base $5^{\prime}$ to adducted dG residues. Densitometric analysis demonstrates that this blockage is quantitative, with a dose-dependent relationship between the intensity of blocks and the level of modiflcation. The level of adduction at any particular dG residue varies by over 11 fold and 1. distinctly nonrandom. Adduction of poly dG sequences 18 invariably favored over ingle dG residues, and within a poly dG region there is a bias for adduction of the $5^{\prime}$ bases. Similarly, transcription of the DNA using SP6 RNA polymerase results in decreasing amounts of full-length RNA with increasing levels of DNA template modification. However, the position of blockage of the RNA polymerase is distinctly different than the DNA polymerase, showing no consistent relationship to adducted dG residues. The results suggest there are clear differences in the manner by which DNA and RNA polymerases process DNA templates which are modified with BPDE. Supported by the U.S. Department of Energy Contract DEACO6-76RLO 1830. 


\section{Cellular Responses to Environmental DNA Damage}

Excision of Ring-Saturated Pyrimidines from the DNA of Oxidized Human Lymphoblasts. Bandi B. Weiss and Patricia E. Gallagher. West Virginia University, Department of Biology, Morgantown, WV 26506.

Oxidation of the DNA bases is caused by a variety of physical and chemical agents in the environment as well as intermediates of normal cellular metabolism. Mechanisms for the repair of many of these lesions have been well defined in both bacterial and mammalian systems. Repair of oxidized pyrimidines from damaged DNA is initiated in mammalian cells by the action of the redoxyendonuclease, the counterpart to E. coli endonuclease III. Both the bacterial and mammalian enzymes have DNA glycosylase activities, releasing ring-saturated or ring-fragmented pyrimidines from DNA damaged by chemical oxidation as well as ionizing and ultraviolet irradition, leaving an apyrimidinic site. An associated apyrimidinic endonuclease activity incises the DNA at the resultant base loss site.

We have investigated the formation and in vivo repair of oxidized pyrimidines in human lymphoblasts following treatment of cultured cells with increasing concentrations of hydrogen peroxide. The extent of DNA damage in total genomic DNA was determined by alkaline sucrose density gradient centrifugation using $E$. coli endonuclease III as a probe. A concentration of $5 \mathrm{mM}$ hydrogen peroxide resulted in detectable levels of enzyme-sensitive sites with greater than $50 \%$ cell survival up to 24 hours after removal of the damaging agent. This method was also used to determine the in vivo rate of repair of ring-saturated pyrimidines in oxidized DNA. Human lymphoblasts were treated with $5 \mathrm{mM}$ hydrogen peroxide for 30 minutes at $370^{\circ} \mathrm{C}$. After removal of the darnaging agent, the DNA was isolated from aliquots of cells harvested at various time intervals and incubated with saturating concentrations of $E$. coli endonuclease III. Analysis of alkaline sucrose gradients showed that excision of oxidized pyrimidines from total genomic DNA occurs rapidly in vivo and is essentially complete within 3 hours.

To examine the in vivo repair of ring-saturated pyrimidines in defined sequences of human DNA, an assay based on the polymerase chain reaction was used. By this method, enzyme-generated strand breaks result in the formation of truncated products as demonstrated by the loss of full-length amplified product. Following treatement of human lymphoblasts with a non-lethal concentration of oxidizing agent, the cells were incubated in fresh medium and aliquots were harvested at various times. Segments of the human genes for dihydrofolate reducatase, glutamate dehydrogenase, creatine kinase, and $\alpha$-tropomysin were amplified using limiting concentrations of the DNAs extracted. The radiolabeled, amplified products of each polymerase chain reaction were separated by polyacrylamide gel electrophoresis and the resultant bands were quantified. Repair of the oxidized pyrimidines in all the defined regions of the genome studied was essentially complete within three hours. These results are in contrast to the rate of removal of bulky adducts from nontranscribed regions of cellular DNA which appears to be a slower process. It is possible that condensed regions of the genome are more accessible to the redoxyendonuclease, a small, single-chain polypeptide, than to a multi-protein complex which is presumably required to repair bulky adducts in cellulair DNA. (Supported by NIH grant CA-47457 and WVU Senate Grant). 
Cellular Responses to Environmental DNA Damage

Analysis of In Vivo DNA Repair Rates of Alkylpurines in Defined Segments of Human Nuclear and Mitochondrial DNA. Paul W. Wright. Randi B. Woiss, and Patricia E. Gallagher. West Virginia University, Department of Biology, Morgantown, WV 26506.

Although most cellular DNA is present in the nucleus, mitochondria contain their own DNA that codes for ribosomal and tRNAs as well as thirteen of the genes that code for the four enzyme complexes of oxidative phosphorylation. In recent years, studies have shown that major deletions and point mutations of mitochondrial DNA cause a number of human neuromuscular diseases, including mitochondrial myopathies and encephalopathies, and Leber's hereditary optic neuropathy. Since: mitochondrial DNA is not complexed with histones or histone-like proteins, it has been suggested that the mitochondrial DNA may be more susceptible to damage by chemical and physical agents. Studies from a number of laboratories suggest that excision repair of damaged base sites in mitochondrial DNA may occur, however, limited information exists on removal of damage from mitochondrial DNA. We have employed an assay based on the polymerase chain reaction to examine the in vivo formation and repair of alkylpurines in defined segments of mitochondrial and nuclear DiNA.

Suspension cultures of human lymphoblasts were incubated with nonlethal concentrations of dimethyl sulfate for 30 minutes at $37^{\circ} \mathrm{C}$. The predominat DNA base lesion formed by this treatment is 7-methylguanine which accounts for more than $70 \%$ of the total DNA damages. Following treatment with dimethyl sulfate, the cells were resuspended in fresh culture media and incubated at $370 \mathrm{C}$ to allow repair of the damaged DNA. At various times, the cellular DNA was extracted and analyzed for the presence of alkylpurines in defined segments of nuclear and mitochondrial DNA.

A polymerase chain reaction assay was developed to detect the in vivo formation and rate of repair of alkylpurine lesions in nuclear and mitochondrial DNA. Samples of human cellular DNA, isolated atter dimethyl sulfate treatment of cultured lymphoblasts, were incubated with hot alkali for 30 minutes to produce single-strand breaks at sites of alkylpurines. Single-strand breaks in the DNA caused the termination of in vitro replication, resulting in the formation of truncated products. Thus, as the alkylpurines are removed from the DNA, the amount of amplified product increases. Segments of the human nuclear genes for dihydrofolate reductase and creatine kinase and two mitochondrial DNA segments that included the coding region for lysyl t-RNA and a subunit of nicotinamide adenine dinucleotide dehydrogenase, respectively, were amplified using limiting concentrations of the alkali-treated DNA. Radiolabeled, amplified products of each polymerase chain reaction were separated by polyacrylamide gel electrophoresis and the resultant bands were quantified. Data analysis showed that the formation of alkylpurines was greater in the mitochondrial sequences studied as compared to the nuclear gene segments amplified. Additionally, it was found that alkylpurines are removed from mitochondrial DNA sequences at a rate comparable to that of the nuclear gene fragments. These data suggest that nuclear encoded DNA excision repair enzymes can traverse the mitochondrial membrane and actively repair mitochondrial DNA damage:: (Supported by NIH grant CA-47457) 
The Adaptive Response of streptomyces coelicolor. A.M.Abel and P.Strike, University of Liverpool, England.

The Gram positive actinomycete, streptomyces coelicolor A3 (2) illicits an adaptive response to alkylation agent induced DNA damage analagous to the response observed in Escherichia coli $B$ and $K$ strains. Pregerminated spore suspensions incubated in the presence of low concentrations of $\mathrm{N}$-methyl-N'-nitro-Nnitrosoguanidine exhibit increased resistance to both the toxic effects of this mutagen and its mutagenic properties, as assayed by its effects on the induced mutation rate at the spectinomycin locus. In addition, chemical cross-induction studies using the DNA-DNA interstrand cross-linking agent mitomycin $C$ and the methylating agent methyl methane sulphonate indicate that this response is specific to alkylating agent induced damage.

A biochemical investigation into the enzyme activities responsible for this in vivo response, in cell free protein extracts, has demonstrated the presence of a constitutively expressed methyltraisferase which shows an apparent 2-3 fold increase in activity upon induction with MNNG. Further, a 3methyladenine DNA glycosylase activity is also present which is apparently constitutively expressed 
Activation of a DNA-Dependent Protein Kinase in Human Cells by DNA Damage and Viral Transformation. Timothy H. Carter ${ }^{1}$, William K. Kaufmann 2, Gregory J. Tsongalis ${ }^{2}$, Ronald H. Blackmon ${ }^{3}$, Ivon Sun 1 and Sam Tang1. 1Department of Biological Sciences, St. John's University, Jamaica, NY 11439, 2Department of Pathology and Lineberger Comprehensive Cancer Center, University of North Carolina at Chapel Hill, Chapel Hill, NC 27599-7295, and 3Elizabeth City State University, Elizabeth City, NC 27909.

A protein kinase activity which requires the presence of double-stranded DNA was recently described in HeLa cell nuclear extracts (Carter et al., BBRC 157, 535, 1988) and was subsequently purified in several laboratories (Carter et al., Mol. Cell Biol. 10, 6460, 1990; Lees-Miller et al., Mol. Cell Biol. 10, 6472, 1990). The kinase (DNA-PK) was not stimulated in vitro by supercoiled DNA, suggesting that structural damage to DNA resulting in nicks or fragmentation might activate this enzyme in vivo. We therefore investigated the effect of $\gamma$-irradiation on protein phosphorylation in permeabilized human fibroblasts. When analyzed by SDSPAGE and autoradiography, phosphorylation of endogenous polypeptides with $M_{r} s$ of $100-105 \mathrm{kDa}$ and $50-80 \mathrm{kDa}$ was found to be stimulated relative to phosphorylation in similar preparations from unirradiated cells. Several of these phosphoproteins had mobilities on SDS-PAGE similar tc those which were phosphorylated in nuclear extracts only in the presence of added, fragmented DNA. Surprisingly, phosphorylation of many of the same polypeptides was independent of added DNA in nuclear extracts from several different fibroblast lines transformed by either SV40 or SV40 T-Antigen. When purified DNA-PK was added to the transformed cell extracts, phosphorylation of the same polypeptides (including the kinase itself) was further enhanced, again without added DNA. Although we can not at present rigorously exclude the possibility that small amounts of DNA might be tightly bound to proteins in the transformed cell extracts, passage through DEAE columns did not remove the ability of the extracts to activate phosphorylation. We propose that activation of DNA-PK is an early cellular response to physical DNA damage. It is possible that disregulation of this enzyme may accompany or contribute to the disruption of normal controls on DNA synthesis which occurs in transformed cells. 


\section{Cellular Responses to Environmental DNA Damage}

DNA sequences that control DNA damage-inducible and competence-inducible regulation of the Bacillus subtilis SOB response. David $L_{4}$ Cheo, Ken W. Bayles and Ronald E. Yasbin. The University of Maryland, Baltimore County, Baltimore, Maryland 21228

The SOS-like or SOB response of Bacillus subtilis is induced both by DNA damage and during the development of natural competence. This induction is dependent upon the activity of the RecA protein. DNA sequences required for expression of DNA damage-inducible (din) genes of $B$. subtilis were identified following the cloning and genetic characterization of the $\operatorname{din} A, \operatorname{din} B$ and $\operatorname{din} C$ promoter regions. The consensus sequence GAAC-N4-GTTC was found within the promoter regions of each of these three din genes. This consensus sequence (or Cheo box) has been proposed to function as an operator site that is required for DNA damage-inducible gene expression in $B$. subtilis. Sequences similar to the Cheo box are also present within the recA gene (which is damageinducible) as well as within the promoter regions of other damageinducible loci involved in processes of DNA repair. Deletion analysis was used to examine the manner in which these sequences function in regulation of the SOB response. A deletion which removes the Cheo box upstream of the $\operatorname{din} A$ gene derepressed the $\operatorname{din} A$ promoter and abolished induction by DNA damage.

Similar studies with the $B$. subtilis recA gene have revealed a more complex regulation. Expression of the recA gene is induced both by DNA damage and during the development of natural competence. DNA damageinduction of the recA gene (like the din genes) occurs by a RecAdependent mechanism, whereas, competence-induction occurs by a RecAindependent mechanism. Thus, expression of the recA gene is controlled by two different regulatory mechanisms. Multiple regulatory sites within the recA gene were identified by a deletion analysis of the recA promoter region. Two Cheo boxes are required for repression of the recA promoter. Deletion of these operator sequences derepressed expression and abolished DNA damage-inducibility of the recA promoter. Induction of the recA gene during competence requires sequences upstream of the Cheo boxes. Further genetic studies have implicated the degS/degU two-component regulatory pathway in the competence-inducible regulation of the recA gene. 
O6-methylguanine-DNA methyltransferase activity in human melanoma blopsies.

Suzanne Eoyházi, Johan Hansson and Ulrik Ringborg. Dept of Experimental Oncology, Radiumhemmet, Karolinska Hospital, S10401 Stockholm, Sweden.

Disseminated malignant melanoma frequently shows intrinsic resistance to cytostatic drugs or aquires resistance to drugs during chemotherapy. DTIC and chloroethyl-nitrosourea compounds are among the most active single agents for treatment of malignant melanoma. MTIC, the active metabolite of DTIC, reacts both with the $\mathrm{N}^{7}$ - and $\mathrm{O}^{6}$-atoms of guanine residues. The chloroethyl-nitrosourea compounds also exert their biological effect by reacting with the 06 -atom of guanine.

The DNA repair enzyme 06-rnethylguanine-DNA methyltransferase (06-MT) reduces the cytotoxic effect of these drugs by removing cilloroethyl- or $\mathrm{m}$ ithyl-adducts from the $0^{6}$-atom of guanine residues.

The aim of this ongoing study is to investigate the variability of O6-MT activity in melanoma metastases and to correlate this to the response to chemotherapy.

Method. Crude cell extracts were prepared from biopsies of human melanoma metastases excised before chemotherapy. The 06-MT activity was measured as the removal of 3H-methyl groups from ${ }^{3} \mathrm{H}$-methylated $M$. Luteus DNA.

Results. The 06-MT activity in the biopsies range from less than 0.05 units $/ \mathrm{mg}$ protein to 2.8 units $/ \mathrm{mg}$ protein. Three of 15 biopsies had very low O6-MT activity. In three patients more than one metastasis was analysed. Two of the patients had similar $0^{6}$. MT activity in their tumors, while the metastases of the third patient were heterogenous in 06-MT activity (range: 0.3-1.4 units/mg). 


\section{Cellular Responses to Environmental DNA Damage}

Cellular resistance to exogenous $\mathrm{H}_{2} \mathrm{O}_{2}$ and experimental metastatic capacity are increased by exposure to inhibitors of DNA synthesis in B16 melanoma cells. Eskenazi. Allen E.: Pinkas J", Whitin J, Cohen HJ, and Frantz CN*, Departments of Pediatrics and Cancer Center, University of Maryland* and University of Rochester Schools of Medicine.

DNA damaging agents induce a mammalian genetic stress response resulting in greater cellular resistance to environmental stressors. We hypothesized that treatment of tumor cells in vitre with inhibitors of DNA synthesis would alter their resistance to exogenous $\mathrm{H}_{2} \mathrm{O}_{2}$ and affect their ability to metastasize. We examined the effects of hydroxyurea (HU), aphidicolin (APH), and cytosine arabinoside (Ara-C) on the B16 G3.12 murine melanoma cell line with respect to resistance to exogenous $\mathrm{H}_{2} \mathrm{O}_{2}$, antioxidant enzyme activity, and metastatic potential. Cells were treated for $72 \mathrm{hrs} \mathrm{(HU,}$ APH) or $24 \mathrm{hrs}$ (Ara-C) and allowed to recover in drug-free medium for $24 \mathrm{hrs}$. All three drug treatments resulted in significantly greater resistance to high concentrations [2 $200 \mu$ mole/107 cells ( $-5 \mathrm{mM}$ or greater)] of exogenous $\mathrm{H}_{2} \mathrm{O}_{2}$. A thre日- to five-fold increase in glutathione peroxidase (GSH-PX) specific activity was seen in HU- and APH-treated cells. Glutathione reductase specific activity was increased two-fold in HU-treated cells. GSH-PX mRNA was specifically increased in HU-treated cells. Catalase specific activity was mildly increased $(\sim 20 \%)$ in HU- and APH-treated cells. GSH-PX and catalase activities approached baseline after 4 days of culture in drugfree medium.

HU-treated B16 cells exhibited a transient increase in metastatic potential that paralleled the changes in antioxidant enzyme activity. Syngeneic C57BV6 mice were injected intravenously with 105 tumor cells, sacrificed twenty one days later, and examined for pulmonary colonization by tumor cells. Injection of HU-treated cells which had recovered in drug-free medium for 24 hrs resulted in three times as many pulmonary colonies as compared with injection of untreated cells. The metastatic potential of HU-treated cells which had recovered in drug-free medium for 4 days was similar to that of untreated cells. APH and Ara-C pretreatment resulted in a seven- and twenty-fold increase in metastatic colonies respectively. Inhibition of the glutathione redox cycle with buthionine sulfoximine abrogated the increased metastatic potential of HU-treated cells.

We conclude that inhibition of DNA synthesis with HU, APH, or Ara-C results in cellular resistance to exogenous $\mathrm{H}_{2} \mathrm{O}_{2}$. This resistance coincides with transient ir creases in antioxidant enzyme activity and a transient increase in the metastatic potential of drug treated cells. We hypothesize that the increased antioxidant potential of drug treated tumor cells may increase tumor cell resistance to oxidative damage in the pulmonary vasculature during the metastatic process. 
Collular Responses to Environmental DNA Damage

In vivo Repair of N-Alkylpurines Sites in the DNA of Actively Growing and Qulescem Human Colls. Ulinke Klotz. Randi B. Weiss, and Patricia E. Gallagher. West Virginia University, Department of Blology, Morgantown, WV 26506.

The DNA of all cells is continuously subjected to damage caused by environmental agents as well as intermediary metabolites. Alkylation of cellular DNA has been shown to produce a number of base modifications. The most predominant lesions include the N-alkylpurines, 7-alkylguanine and 3-alkyladenine. If not actively removed, 7-alkylguanine will spontaneously depurinate leaving an apurininc site. This base loss site, if not repaired, can result in mutagenesis following the next round of DNA replication. 3-alkyladenine has been shown to block the action of DNA polymerases. For this reason, it's persistence in cellular DNA is considered a lethal event. Studies focussing on the repair of these alterations have demonstrated that excision of damaged bases is cell cycle dependent. In particular, removal of 7. alkylguanine cjccurs most rapidly during the pre-S phase with little or no repair of these damages during DNA replication. The efficiency of repair of $\mathrm{N}$-alkylpurines in the DNA of nonproliferating cells has not been extensively studied. Therefore, we have undertaken a study of the excision of these lesions from defined sequences of DNA of actively growing and quiescent cultured human astrocytes.

The formation and rate of removal of alkylpurines from cellular DNA was studied following in vivo treatment of cultured human astrocytoma cells with dimethyl sulfate. Actively growing cells were treated with $200 \mu \mathrm{M}$ dimethyl sulfate for 30 minutes at $37^{\circ} \mathrm{C}$. It was determined that this dose results in greater than $50 \%$ cell survival following removal of the alkylating agent. After removal of the dimethyl sulfate, the cells were incubated in fresh medium and the cellular DNA was extracted at various times. The presence of $\mathrm{N}$-alkylpurines in regions of the genome encoding segments of the genes for dihydrofolate reductase, glutamate dehydrogenase, and creatine kinase was detected using a polymerase chain reaction assay. Prior to amplification, DNA samples were incubated in $1 \mathrm{M}$ piperidine for 30 minutes to generate apurinic sites and subsequent single-strand breaks at sites of alkylpurine lesions. Since single-strand breaks terminate the action of replicative DNA polymerases, the presence of these lesions in cellular DNA was detected as a decrease in amplified product. Removal of alkylpurines from cellular DNA was detected by the formation of full length, amplified products over time. In actively growing cells, the excision of these base damages occurred with a half-life of approximately 30 hours. As 7-methylguanine comprised greater than 70 percent of the damaged residues, it is presumed that the half-life value obtained reflects the in vivo repair of the 7-methylguanine lesions.

The repair rate of $\mathrm{N}$-alkylpurines was also examined in quiescent cells. Human astrocytes were maintained in serum-free medium for 24 hours to inhibit proliferation. DNA was isolated from dimethyl sulfate treated quiescent cells and analyzed by the polymerase chain reaction assay as described. Removal of DNA methylation damage occurred at a three-fold decreased rate in quiescent astrocytes as compared to actively dividing cells. This rate is comparable to the in vivo rate of spontaneous depurination of 7-alkylguanine in DNA. The results of this study indicate that cells in logarithmically growing cultures may be more proficient in removal of such damage than cells whose proliferation is arrested. (Supported by NIH granit CA-47457) 
Cellular Rasponsa to Invironmental DNA damage

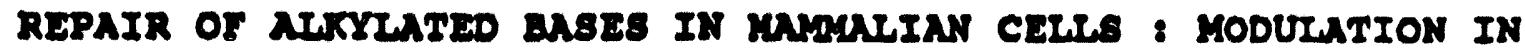
REBPONBE TO DNA-DANAGING AGINTE.

Yvette fiabraken, Iwonsa Rabden-staron and Eranootin rival. Groupe "radiochimie de 1'ADN", 0247 INSzRY, Inet Itut Guntave Rouesy, 94805 V11lajulf, France.

When cello are treated with alkylating agents, a variety or leslons are produeed in DNA, Inoluding modilied bases, sugars and phosphotrlesters. Anong these lesions, N3methyladanine residues, which block DNA roplication and may load to cell death, are rapalred by a epeciele N3methyladen Ine-DNA-glyooeylare. of-methy Iguanine residues, whlch ohange base palring, lead to mutagenlo ovente and are almo lmplicated in the toxic erfect of the chlorocthylnitrosoureas used in cancer therapy. Theqe realdue are repalred by a "oulcide" protein, the ofmethylguanine-DNh-methyltraneferase (trancferase).

We have shown that when hopatoma cell IInea from rat ( H4 celle) or human ( IICH oelis) origin are treated with a single dose of varioue physical (e.g. Uv-1lght, $x$-rays) or chomical (0.9. alkylating druge, elipticins) agents, the activity of these two rapalr protelne 1ncreases. Th1s reaponse is only Induced by agents which produce DNA damage. The two repalr activities increase with the dose dalivered to the celle and are maxlmus about three cell doublinge after the treatmonts. This enhancoment ceams to nocur preferentially in transformed cel1s. It is blooked by cycloheximide and by actinowycin $D$, suggeating that it is due to enhaneed transeription.

we have 1solated two oDNA expreseing elther the N3methyladenine glyoosylase ( APDG CDNA) or the tranefarace ( RMGMT CDNA, from H4 cells and used them as probes to measure the level of mRNA transoripts in the induced cel1s, by Northern blot analysic. similar experiments were run using CDNA expressing elther the human transferase or the buman glyoorylase to neasure the level of mRNA in IICH ce118. Results ohow that the mRN synthesis is enhanced in cells treated with the DNA-damaging agente. The onhanced transoription of the glycosylase and transierase mRNA is transient, with the largest Increase beling observed 48 hrs after the varlous treatmente. As the cellular resietance to the chloroethylnitrosoureas depends on the number of transferase molecules per oeli, we have measured the resistance of colle traated with DNA-damaging agents to the toxle effect of BCNo. The results bhow that the entranced repair activitios may have laplications in the onset of. tumor resletance to alkylating druge. 
Cellular Responses to Environmental DNA Damage

Analyele of durp fydrolysis as a Function of the cell Cycle Jennk J. Inmoh and sal Caradonna UTDIJ-80X

401 south cantral Plaza

stratford, NJ 08084

dOIP nucleotidohydrolase (duTPase) catalyzes the hydrolysis of dUTP to dUNP plus inorganic phosphate and serves to clear dUIP Irom the DWA aynthetle patbway. dUIP that 18 incorporated into DNA in the form of dUxp is removed by a base excleion ropair process. Elevated levels of dUnP,

incorporation into DNA would result in increased repair activity. If intracellular duTP pools are high, reincorporation and additional repair would lead to elevated ctrand breaks. Thus a compromise in durpase activity, reaching a threshold level, could concelvably result in hyper-recombination phenotypes and promote genomic Instabil1ty. This is illustrated in mutants of E.coli with decreased levels of dUIPase activity. It has been shown that these mutants have a hyper-recombination phenotype

(Hochhauser, 8.J. and We1se, B.. J. Bactorlol. 134:157-166, 1978). In (terms of the eukaryotic system, affects of perturbation of dUTPase activity on gonomic ntability have not been analyzed in any great detall. It would seem? from evidence provided by prokaryotic studies, that defects in eukaryotic dUTPase would lead to increased strand breakage.

To this and, we have begun to look at duTPase activity and protein levels in different phases of the Hela cell cycle. This analysis so far has revealed several findings. The most interesting finding is that duTPase activity decreases 4-5 Fold during 8-phase. This is not due to lower protein levels since peak protein synthesis occurs at this time (during s-phase). durpase is a phosphorylated protein and it appears that phosphorylation of dUTPase increases from GI through $s$ phase. These studies indicate that dUTPase activity fluctuates. during the cell cycle in a manner that is not consistent with its function to prevent dUSP incorporation into DNA. Cellular Eractionation of asynchronous cells reveals that dUTPase is largely assoclated with the nuclear fraction. It also appears that duTpase protein is associated with other proteins in the cell. forming molecular weight complexes of about 150 kdaltons. We are currently analyzing complex formation as well as cellular localization at different points in the cell cycle to determine whether this may affect duTPase activity. 


\section{"Cellular Responses to Environmental DNA Damage"}

Differential expression of damage-specific DNA-binding proteins in enkaryotic cells exposed to UV-light. Mary P. McLenigan, Mahipal Singh, Steven Hirschfeld, Arthur S. Levine, and Miroslava Protic', National Institute of Child Healib and Human Development, NIH, Bethesda, MD 20892

DNA-binding proteins which recognize modified bases, bulky lesions, abasic sites or mispairs in DNA, rather than a specific DNA sequence, are termed damage-specific DNA binding (DDB) proteins. In analogy to damage-recognition proteins in procaryotes, DDB proteins are postulated to be a component of mammalian DNA repair complexes with a role in targeting the other repair components to a particular lesion in DNA. Our goal is to identify, purify, and clone proteins in mammalian DNA repair complexes that directly interact with damaged DNA. Once cloned and overproduced, DDB proteins can lead us to the other, yet unidentified, members of the mammalian excision repair pathway.

Using a modified band shift assay, we have recently identified (Hirschfeld et al, Mol. Cell. Biol. 10: 2041, 1990) and purified (Abramic' et al., J. Biol. Chem., in press) a constitutive DDB protein from monkey cells with high affinity for double stranded UV. irradiated DNA, and enhanced expression in UV-pretreated cells. DDB proteins with similar binding characteristics are present in various human cell lines, but are not detected in cells from some DNA repair-deficient patients [(xeroderma pigmentosum, complementation group E (Protic' et al, Mol. Toxicol. 2: 255, 1989)]. To determine whether the expression of UV damage-specific DDB proteins can be correlated with the cell's capacity to repair UV-damaged DNA, we are determining the phylogenetic, tissue, and developmental distribution of DDB proteins in cells with differing repair capacities.

On the basis of the results obtained with primate cells, we have established four criteria to identify DDB-like proteins in other species: (1) high affinity for UV-damaged DNA; (2) absence of the DDB-specific band in the band shift assay immediately after UV irradiation; (3) recovery and induction of the DDB-specific band $24-48 \mathrm{~h}$ post-UV irradiation; and (4) the position of the UV-specific band with respect to primate DDB in the band shift assay. DDB-like proteins that satisfied the first 2 criteria in repair-deficiert cells, and the first 3 criteria in repair-proficient cells, were detected in rodent, marsupial, chicken, turtle, and fish cells, indicating evolutionary conservation. CHO cells, PC-12 (rat pheochromocytoma) cells, Xenopus oocytes, and insect ovary cells show either very weak or undetectable levels of DDB-like proteins. Our results indicate that the constitutive presence of DDB-like proteins cannot be directly correlated with the cell's capacity for excision repair of UV photoproducts, or photoreactivation. However, repair-deficient cells show significantly slower kinetics of the DDB protein recovery after UV irradiation in comparison to repair-proficient cells. These data suggest that DDB proteins may be sensitive indicators of carcinogen exposure. 


\section{Cellular Responses to Environmental DNA danage}

THE INDUCTION OF PHOTOREPAIR OF VERTEBRATE CELLS BY FLUORESCENT LIGHT PRE-ILLUMINATION

H1rosh1 MITANI. ShOu KAKIZANA, ICh1ro ITAI and AkIh1ro SHIMA: 20010gical Institute. Faculty of Sclence, University of Tokgo: Tokyo 113

The enhancement of photorepair of UV-Induced pyrigidine dimers by fluorescent light prelilumination(FLP) was previously reported with RBCF-1 cells derived fron caudal fin of a goldfish (Yasuhira et al.. Photochen. Photoblol.,53, 211-215,1991). Te also found the sinilar enhancement of photorepair by fluorescent light preilluaination in cultured fros cells (XTC) and chicken cells (LMH). The experinents using a protein synthesis inhibitor suggest that the expression of photolyase gene Itself can be enhanced by FLP (Yasuhlra et al.. In press). By tro dimentional gel electrophoresis of total protelns of RBCF-1 cells, the several protelns which were induced at 8 hours af ter :LP were-1dentifled.

We tried $t /$ isolate the photolyase fron goldfish livers. The goldi-sh livers were howogenlzed and following precipltation with amoniun sulfate and centrifugation, the sample was applied to a BlueSepharose column, and photolyase was eluted with a high salt solution. And then, the sanple was loaded onto a hydroxylapatite coluan (33-330 my phosphate) and Blue-Sepharose colunn $(0.1-1 \mathrm{M} \mathrm{KCl})$. The photolyase activity of each fraction was assayed by reduction of the number of UV endonuclease sensitive sites in UV-Irradiated plasidds after fluorescent light treatment. The photolyase fraction thus obtained contalned $0.13 \%$ of ammonium sulfate-precipltable protein and the photolyase activity was about 5000 tines higher than that of the first erude extract. The SDS-PAGE analysis showed that there rere three aajor proteins in this fraction ( $33 \mathrm{kDa}, 35 \mathrm{kDa}, 105 \mathrm{KDa}$ ). $33 \mathrm{kDa}$ protein was one of fluorescent light induced proteins. However, on further purification the photolyase activity was lost, so we are now repeating. sinilar experinents using nore starting tissues. 
"Cellular Responses to Environmental DNA Damage"

Combined Effects of Ionizing Radiation and Cycloheximide on Gene Expression. Gayle F. Woloschak, Paolo Felcher, Jeff Jones, ChinMel Chang-Iiu, M. Anne Gemmell, and Carol S. Giometti. Argonne National Laboratory, Blological and Medical Research Division, 9700 South Cass Avenue, Argonne, II 60439.

Previous work by our group has shown that a variety of genes are modulated following exposure to lonizing radiation, though the mechanism(s) responsible are unknown. We determined the effects of Ionizing radiation exposure on the expression of genes (such as B-actin, c-Eos, H4-histone, c-myc, c-jun, $R b$, and p53) following exposure of Syrian hamster embryo (SHE) cells to the protein synthesis inhibitor cycloheximide. Then ionizing radiations (either JANUS fission-spectrum neutrons or $\gamma$-rays) were administered $15 \mathrm{~min}$ following cycloheximide treatment, the radiation reduced gene induction for most (c-fos, H4-histone, c-jun) of the cycloheximide-inducible genes. In addition, high dose rates save the most significant inhibition of the cycloheximide response regardless of IET or total dose. The mPNA preparations derived from the SHS cells were translated in vitro. The translation products were analyzed by 2 odimensional gel electrophoresis (2DE), and results revealed genera: refression by Ionizing radiation of the gene products induced by cycloheximide exposure. Our results suggest that the presence of a lablle protein is required for the maintenance of transcription and mRNA accumulation following radiation exposure, especially for radiations administered at high dose rates. The dramatic differences between radiation exposure at high and low dose rates suggest different, dose-rate-dependent mechanisms of radiationmediated transcriptional inhibition. In addition, our experiments suggest that high-LET radiation may actually be more repressive of gene expression following cycloheximide exposure than low-IET radiation.

This work was supported by the U. S. Department of Energy, Office of Health and Environmental Research, under Contract 1 w-31-109-ENG-38. 
Charaoterisation of UV-Reaponse nlemont (Upr) - Bound protalng. - X.1. Yang. 3.8. Rutberg. P.G. Folls and 8. Ronel. Molecular Carolnogenosis progran, Inerion Eoalth Foundat10n, Falbal1a, irs 10595.

we have previously reported on the identification of a UV-response element (URE) which represents a novel DNA target sequence, (TEACAACA) and plays a positive role in the replication of polyoma DNA. We have identifled the profile of nuclear proteins that binds this sequence in UV-exposed rat flbroblast cells through affinity chromatography. The URE-bound eraction consists of 4 proteins as revealed through SDS PAGE, the most abundant protein has a $\mathrm{kN}$ of $40 \mathrm{kda}$.

Polyclonal antibodies raised in mice against the UREbound proteins are capable of recognizing mainly the 40kda protein in a nuclear protein extract of rat fibroblast cells that were exposed to UV 11ght. The 40-kda protein was also found to be induced by DNA damaging agents such as X-rays, UV-B, benzo(a) pyrene, and heat shock. Thus, the induction of this protein. is not UV-specific but is a response, to a wider range of DNA damaging agents. Moreover, the Induction of the $40 \mathrm{kda}$ protein was also observed in human keratinocyte cells upon ov-exposure suggesting that this response is not species-linited.

It appears that $40 \mathrm{kda}$ protein is induced through post-translation modification as increased levels of this protein were observed after treatment of the cells with forskelin, a known inducer of the adenylate cyclase pathway suggesting phosphorylation of this protein occurs upon induction 


\title{
Cellular Responses to Environmental DNA Damage
}

\author{
Poster Session B \\ Tuesday, December 3, 1991 4:30 p.m. - 6:30 p.m.
}

Mutagenesis and Recombination

POSTERS $1-29$

Repair Gene Cloning/Human

POSTERS $30-45$

Repair-Deficiency Diseases

Cancer and Aging

POSTERS 46-66 


\section{.TARGETED RECOMBINATION AT THE ENDOGENOUS APRT LOCUS IN DNA REPAIR-PROFICIENT VERSUS REPAIR-DEFICIENT (ERCC1-) CHINESE HAMSTER (CHO) CELLS. Gerald M. Adair, Debra G. Smith, Katherine A. Brotherman, Shari Mason, Amir Salim, and Keith A. Crow. The University of Texas M.D. Anderson Cancer Center, Science Park-Research Division, Smithville, Texas 78957.}

In yeast, a number of DNA repair gene loci have also been shown to affect certain types of recombination. The yeast RADI and RAD10 genes, which are in the same epistasis group for excision repair, also appear to be involved in a common pathway of mitotic recombination. radi $\Delta$ and radi0 $\Delta$ mutations have been shown to markedly reduce the frequencies of targeted integration or excisive recombination between direct repeats in yeast, appearing to primarily affect crossovers and reciprocal exchanges. Based on DNA sequence and amino acid homologies, ERCCl gene appears to be the mammalian equivalent of the yeast RADI0 gene, and ERCC1- mutants show UV sensitive, repair-deficient phenotypes similar to those of rad10 mutants. We have developed a system which permits the analysis of targeted homologous recombination at an endogenous chromosomal locus in cultured mammlian cells. We utilize hemizygous, APRT CHO cell mutants to assay the efficiency of recombinational correction of otherwise nonrevertible APRT deletion mutations, by targeted homologous recombination of electroporation-introduced APRT sequences with the defective chromosomal APRT locus. APRT mutant cells containing a single, deletion-inactivated copy of the Chinese hamster $A P R T$ gene are electroporated with a PSV2gpt-derived APRT targeting vector containing $\sim 3.5 \mathrm{kbp}$ of APRT sequence homology. This targeting vector can be cut at unique EcoRI or Sacl restriction sites to generate either a targeted insertion-type, or gene replacement-type configuration. Approximately $48 \mathrm{hrs}$ after electroporation, the cells are plated into ALASA (alanosine, azaserine, adenine) medium to select for APRT ${ }^{+}$recombinants; at the same time, a small portion of each population is plated into HAT medium to monitor the frequency of nontargeted integration of targeting vector sequences. To examine the effects of a specific DNA repair defect (an ERCC1 ${ }^{-}$mutant phenotype) on targeted (homologous) and nontargeted recombination in mammalian cells, we have carried out a series of APRT gene targeting experiments employing matched pairs of repair-proficient / repair-deficient APRT mutant cell lines containing identical (or very similar) APRT target gene deletions. The repair -proficient ATS-49tg and repair-deficient, ERCC1- mutant U9S-50tg cell lines contain identical,3-bp exon-V APRT gene deletions, while the repair-proficient ATS-3tg and repair-deficient U9S-43tg cell lines contain similar 1.3 to 1.5-kbp intermal APRT gene deletions. Preliminary results of targeting experiments utilizing these four cell lines suggested that the repair-deficient, ERCC1 ${ }^{-}$mutant cell lines showed only slightly lower frequencies of targeted (homologous) recombination and nontargeted integration of transfected sequences. However, Southem blot analysis of APRT ${ }^{+}$recombinants revealed a marked shift in the distribution of targeted recombination events observed in repair-proficient versus repair-deficient cell lines, with the repair-deficient, ERCCI- mutant cell lines showing a specific dectease in the frequency of targeted integration events, which would involve crossover and reciprocal exchange. Thus, the RAD10 and ERCC1 repair genes may play similar roles in yeast and mammalian recombinational pathways, as well as in excision repair. (This work was supported by NIH grant CA-28711). 


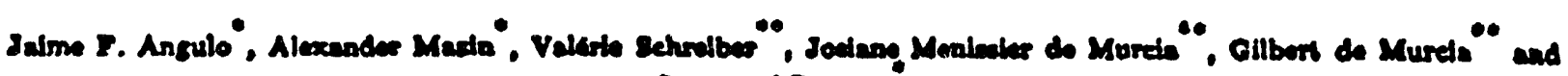
- Ropmoad Devonet.

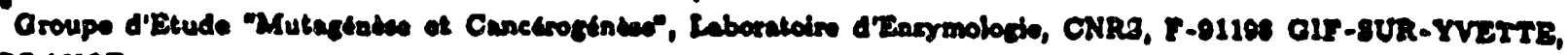
PRANOE.

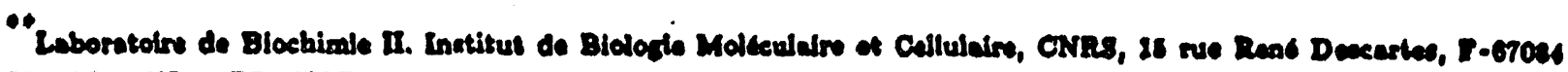
ETRUSBOURO, FRANCE.

We have recently cloned mouse CDNA called KINI7. Genomic sequences homolo80us to KINI7 CDNA were detected in rat and human DNAs suggesting that KINI7 gene is conserved among muitmals. KINI7 mRNA is highly expressed in mouse transformed AtT-20 neuroendocrine cells whereas it can be detceted only in the total RNA of mouse embryos and various norinal adult tissues by reverse transcription and PCR amplification. More importanl, KIN17 gene codes for a mouse protein of $44.6 \mathrm{kDa}$ strongly reactive with antirecA antibodies. The deduced equence of kinl7 protein has a small 39-residue region similar to recA protein. This region might be responsible for the cross-resctivity between kinl7 protein with anti-recA antibodies and seems to be involved in DNA-binding. Kin17 protein displays also a $\mathrm{Zn}$-binding motif and several putative nuclear localization signals (Angulo ot al., 1991, NAR, in press). By recloning KINJ7 CDNA into an appropriato expression vector, we produced kin17 protein in $E$. coli, purified it partially and shown that kin 17 protein binds to double-stranded DNA. Apparently, kinl7 protein binds to zinc jons probably through the $\mathbf{Z n - b i n d i n g ~ m o t i f . ~ P r e l i m i n a r y ~ r e s u l t s ~ f a v o r ~ t h e ~ h y p o t h e s i s ~ t h a t ~ t h e ~} \mathbf{Z n}$-finger is involved at lcast partially in kin17-DNA interaction. Furthermore, one of the putative nuclear localization signals of kinit protein is sufficient to direct the enzyme beta-galactosidase to the nucleus of HeLa cells. Taken together these results confirm that kin 17 is a nuclear protoin implicated in DNA transactions which seems to be highly conserved among eukaryotes. The hypothesis that functional domains of recA protein may have burst out and spread on to several mammalian proteins involved in a DNA metabolism will be discussed. 


\section{Cellular Responses to Environmental DNA Damage}

In vitro mutational specificity of cisplatin in the human HPRT gene

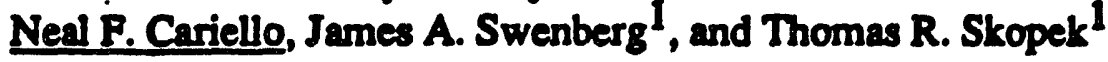

University of North Carolina, Pathology Department, Chapel Hill, NC 27599

1 University of North Carolina, Environmental Sciences and Engineering, Chapel

Hill, NC 27599

Cisplatin [cis-diamminedichloroplatinum(II)] is an antitumor agent and has been used in the treatment of various human cancers. Cisplatin is a bifunctional agent, capable of cross-linking DNA bases, and preferentially forms intrastrand crosslinks between the $\mathrm{N} 7$ atoms of adjacent purines. Although cisplatin is a valuable chemotheraputic agent, it also has potential deleterious side effects. Cisplatin is mutagenic in a variety of systems and is carcinogenic in both rats and mice. It is important to understand both the mutagenic and antitumor activities of cisplatin. One method to examine the mechanism of action of cisplatin is to study the pattern of DNA mutation that it produces.

We examined the in vitro mutational spectra of cisplatin in exon 3 of the human HPRT gene in B lymphoblasts by a combination of polymerase chair. reaction (PCR) and denaturing gradient gel electrophoresis (DGGE). Several thousand independent mutants were induced at the HPRT locus by cisplatin and were selected en masse by addition of 6-thioguanine to the bulk culture. PCR was used to amplify exon 3 from the complex mutant population and DGGE was used to separate wild type DNA sequences from mutant sequences. Mutational hotspots were visible as discrete bands on the denaturing gradient gel. Scanning densitometry was used to determine the fraction of the complex population represented by the novel bands. The mutant bands were excised from the denaturing gradient gel and sequenced. In this $w a y$, the nature and frequency of mutational hotspots in a population of several thousand mutants was determined.

Cisplatin produced several mutational hotspots in exon 3. About 9-10\% of the cisplatininduced mutants had mutations in a GGGGGG sequence (base pair 207-212). GC->AT substitutions at the second and third guanines in the $5^{\prime}$ GGGGGG $3^{\circ}$ run comprised about $2 \%$ and $4 \%$ of the induced mutants, respectively. About $4 \%$ of the induced mutants contained a GC- $>$ TA substitution at the sixth guanine. About $1 \%$ of the cisplatin-induced mutants had an AT->TA transversion in a TAGA sequence (base pair 271; mutated base is underlined). GpG and ApG sites have previously been identified as the primary sites of cisplatin adduction, our results are consistent with mutations occurring at these adduction sites.

Our results both are in concordence with and in disagreement with the single adduct mutational spectrum of cisplatin in prokaryotes. Fuchs and coworkers found that a single ApG cisplatin adduct produced mainly AT->TA transversions at the $5^{\prime}$ adenine. Our results are in agreeement with this observation, we found an AT->TA transversion at a TAGA sequence.

Unpublished work by Essigmann showed that the GpG cisplatin adduct produced mainly GC->TA transversions at the S' nucleotide. In general, our results do not agree with these observations. We found GC->AT transitions at the second and third guanines in the GGGGGG sequence and GC->TA transversions at the last guanine. GC->TA transversions at both the second and third guanine produce selectable mutants, 80 the failure to detect GC->TA transversions is not the result of the selection system. Our results indicate that cisplatin can produce GC->AT transitions as well as GC->TA transversions, and that the adducts probably involve GpG sequences. 


\section{Cellular Responses to Environmental DNA Damage}

RESUMPTION OF REPLICATION IN ESCHERICHIA COLI AFTER UV IRRADIATION REQUIRES RECF. Priscilla K. Cooper, Division of Cell and Molecular Biology, Lawrence Berkeley Laboratory, University of California, Berkeley, CA. 94720.

In Escherichia coli, the blocks to replication fork progression that are introduced by UV irradiation result in the activation of RecA protein for its role in SOS induction and for its direct participation in certain SOS functions. The release of blocked replication forks and recovery of DNA replication have themselves been shown to require SOS induction, reflecting a requirement both for induced levels of RecA protein and for synthesis of some other induced protein (Khidhir et al, MGG 199:133, 1985; Witkin et al, PNAS 84:6805, 1987; Cooper, unpubl. observations). Although dependent on SOS induction, replication resumption is independent of UmuDC in recAt cells and hence does not primarily reflect the mutagenic bypass of lesions. Recovery occurs in both excision-proficient and excision-deficient strains. However, our evidence indicates that there are at least two UmuDC-independent mechanisms of replication recovery, one of which is dependent on SOS-regulated excision repair. In excision-proficient but not excision-defective cells, induction of SOS functions prior to irradiation allows a much more rapid recovery of replication as compared to the time required for replication to resume when naive cells are irradiated. This accelerated recovery does not appear to be simply a reflection of more rapid removal of damage resulting from initial high levels of UvrABC nuclease, since it (like the Uvr-independent process) is completely dependent on RecA protein even when all other SOS functions are induced at the time of irradiation. In addition to the UvrABC nuclease, one component of the resynthesis step of excision repair, long patch repair, is also under SOS control (Cooper, MGG 185:189, 1982). We have recently obtained direct evidence that long patch repair of UV damage preferentially operates at lesions in the vicinity of replication forks. Hence long patch repair may be the uvrt-dependent process involved in release of blocked replication forks.

The recF gene controls a minor pathway of conjugational recombination in $E$. coli, which however plays a major role in postreplication daughter strand gap repair. Mutants of recF are UV sensitive and have been shown to be defective in SOS induction as well as in the recombinational processing of daughter strand gaps. Mutations in recA that increase the ability of RecA protein to bind to single-stranded DNA can partially suppress the effects of res mutations. These facts, together with the demonstration that RecF itself has DNA binduing activity, suggest a role for RecF in activation of RecA by facilitating its binding to sites of damage (Madiraju, Templin and Clark, PNAS 85:6592, 1988; Sassanfar and Roberts, J. Bact. 173:5869, 1991). We have shown that RecF is also required for long patch excision repair. This requirement is suppressed by the recA441 mutation when cells are grown at 420 in the presence of adenine, conditions which restore wild-type UV resistance to recF uvrt cells but not to recF urrA-. Because of the correlation between induction of long patch repair, increased UV resistance, and early recovery of replication after UV, we have examined the effect of a recF mutation on post-UV replication resumption in an excision-proficient strain and find that RecF is essential for recovery. Experiments are in progress to determine whether the requirement for RecF in replication recovery reflects its role in SOS induction or its recombinational role. 
Independence of action of the two ends at a double-strand break.
P. J. Hastings*,
C. B. MoGill,
B. Shafer and J.
N. Strathern

Laboratory of Eukaryotic Gene Expression, National Cancer Institute, Frederick, Maryland

-Permanent address: Dept. of Genetics, University of Alberta, Edmonton, Alberta, Canada

If the two ends of a broken DNA molecule cooperaite in their invasion of an homologous molecule to achieve double-strand break repair, it might be expected that the efficiency of ends-out integration of a plasmid would be much lower than the efficiency of ends-in integration, because only the latter situation is a reasonable imitation of a double-strand break. To investigate this question, we constructed a yeast strain which contained two unlinked targets for the same plasmid, one of which would be seen by the plasmid as an ends-in event, the other as an ends-out event.

The data show that ends-in integration is about three times as common as ends-out. The two targets were seen to be equally hot when the event at the two targets was the same. In a few percent of events, the plasmid integrated at one target at one end and at the other target at the other end. This event was seen as a reciprocal translocation. These observations are interpreted to mean that the action of the two ends is largely or fully independent. 
Cellular Responses to Environmental DNA Damage

Overproduction, Purification and Cleavage of MucA Proteins Correlation of In vitro Cleavage with Inducible Mutagenesis.

Janet Hauser Arthur S. Levine, and Roger Woodgate.

Section on Viruses and Cellular Biology, National Institute of Child Health and Human Development, Bethesda, MD 20892.

Exposure of Salmonella typhimurium or a number of other prokaryotes to a wide variety of chemical mutagens results only in a modest increase in the mutation rate. The mutation rate, however, increases dramatically if the strain carries certain naturally occurring plasmids, such as pKM101. The increased mutation rate is dependent upon the bost cell's recA-lexA controlled inducible SOS response to DNA damage, as well as the products of the plasmid encoded mucA,B genes, which are functional homologues of the chromosomally encoded umuD, C genes from Escherichia coli Continuing our studies into the mechanisms of mutagenesis, we have overproduced the MucA protein by placing it under the direct control of the strong bacteriophage $\lambda P_{\mathrm{L}}$ promoter. Using this overproducing system, we have been able to purify MucA protein. In vitra purified MucA was processed by a mechanism similar to that previously reported for both LexA and UmuD proteins. The rate of autodigestion, and RecA-mediated cleavage of MucA was less efficient than that of the LexA repressor protein, buit significantly more efficient than that of the functionally homologous UmuD mutagenesis protein. We propose that the increased rate of MucA cleavage compared to UmuD cleavage under similar conditions may explain the phenotypic differences in tha efficiency of mutagenesis promoted by the mucA,B and umuD,C operons in vivo. 


\section{Cellular Responses to Environmental DNA Damage}

In vitro Replication of H-ras zene catalyzed by Calf Thymus DNA Polymerase- $\alpha$ Ienn-Sebastien Hoffmann ${ }^{1}$, Michael Fry ${ }^{2}$. Kandace J.Williams ${ }^{3}$ and Lawrence A Loeb 1

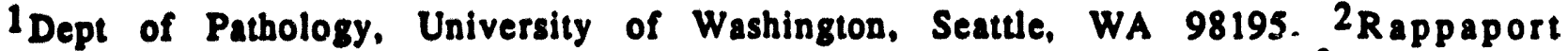
Institute, Technion-Israel Institute of Technology, Haifa, Israel and 3 Biomedical. Program, University of Alaska, Anchorage, Ak 99508.

Mutagenesis of proto-oncogenes is thought to contribute to the initiation and progression of human cancer. Base substitutions in the H-ras gene often seen in human tumors have been found to cluster primarly at codons 12, 13 or 61. DNA polymerases, which consistently generate 'hot spots' of point mutations during DNA synthesis in vitro, are potential endogenous sources of mutations.

Synthesis of DNA by purified DNA polymerases is commonly characterized by discrete pausing sites along the template. To examine whether these sites are hots spots for: nucleotide misincorporation, $5^{32} \mathrm{P}$ labeled primer was annealed to M13mp2 DNA and extended by the calf thymus DNA polymerase- $\alpha$. Pause sites were determained by denaturing polyacrylamide gel electrophoresis and the bands were individually purified. Specific pause sites terminated with a mismatch nucleotide, suggesting that certain hot spots of mutagenesis correspond to DNA template sites that inhibit the progression of pol 0 .

Exon 1 of the bumalm H-ras gene was inseried into M13mp2 and copied in vicro by DNA polymerase-a. A stirong termination site was found in the vicinity of codons 12 and 13. This pausing site is released when the template is mutated at the middle base of codon 12, the same alleration that converts $\mathbf{H}$-ras into an activated oncogene. This termination site could also be a hot spot of mutagenesis. We will investigate the capacity of the enzjme to generate mutations when bypassing this site. 
Cellular Responses to Environmental DNA Damage

Cel1-cycle-dependent induction of chromosome aberrations by ultraviolet light in diploid human fibroblasts. William Ke Kaufmann and Sandra J. Wilson, Department of Pathology and Lineberger Comprehensive Cancer Center, University of North Carolina at Chapel Hi11, Chapel Hill, NC 27599-7295.

The demonstration of frequent allelic deletions in colon cancer has reemphasized the importance of clastogenesis in carcinogenesis. He have investigated the mechanisms of induction of chromosome aberrations in ultravioletirradiated diploid human fibroblasts. Synchronous populations of fibroblasts were irradiated with UV at various phases of the cell cycle and then harvested during the first wave of mitosis that followed irradiation." Metaphase spreads were stained with Gfemsa and the ylelds of chromosome aberrations were quantified. Uitraviolet irradiation induced exclusively chromatid-type chromosome aberrations which included chromatid breaks and exchanges. Fibroblasts that were irradiated when in $G_{0}$ and then immediately replated to stimulate cell division displayed the fewest numbers of aberrations. Cells that were irradiated when at the $G_{1} / S$ border displayed the greatest numbers of aberrations. Cells in the middle of $G_{1}$ when irradiated displayed intermediate levels of aberrations. Irradiation of $G$ cells was shown to produce a fluence-dependent reduction in the rate of entry of cells into the $S$. After $10 \mathrm{~J} / \mathrm{m}^{2}$ of UV, initiation of DNA replication was inhibited by about 66\%. This delay in entry of damaged cells: into the $S$ phase has the beneftcial effect of providing more time for repair of potentialiy clastogenic DNA damage before the onset of DNA replication. These studies confirm that UV is an $\mathrm{S}$-phase-dependent clastogen. The results also imply that interuption of DNA polymerase at UV-induced pyrimidine dimers in template strands may lead to DNA double strand breaks. Supported by PHS grant CA42765. 
"Cellular Responses to Environmental DNA Damage"

Transcription-Induced deletion mutation mediated by a triple-hellx fórming sequence, poly(dG)-poly(dC). Yurij Panchenko, Sergei Malkhosyan, Terumi Kohwi-Shigematsu and Yoshinori Kohwi La Joila Cancer Research Foundation, 10901 North Torrey Pines Rd., La Jolla, CA, USA

The DNA sequences that readily adopt non-B DNA structures under superhelical stress are often found within regulatory regions of DNA. The promoter region of the chicken $\beta^{A}$. globin gene contains a string of $16 \mathrm{dG}$ residues, and this binds specifically to an 6 ythrocyte factor. The G-string provided one of the earliest examples of supercoiling-dependent sensitivity to single-strand specific nucleases. We chose the poly(dG)-poly(dC) sequence as a model system to study unusual physical properties on biological responses. Poly(dG)-poly(dC) sequences adopt an intramolecular dG.dG.dC triplex in the presence of $\mathrm{Mg}^{++}$and dC+.dG.dC triplex in the absence of $\mathrm{Mg}^{++}$(1). The triplex formation depends critically on the sequence's length under given ionic conditions (2). Therefore, poly(dG)-poly(dC) sequences of varying lengths can be used as probe to study whether a non-B DNA structure plays a role in cellular biological function. Kohwi and Kohwi-Shigematsu found a strong enhancing activity by poly (dG)-poly(dC) sequence depending on its length in mouse LTK- cells (3). Recently, the formation of an intramolecular dG.dG.dC triple-helix structure by a poly(dG)-poly (dC) sequence was demonstrated in E.coli cells by in situ chemical probing (4).

Our studies have also been directed towards understanding the molecular mechanisms of spontaneous mutational events, focusing on the possible role of non-B DNA structure. Particular sequence arrangements of DNA, such as direct repeats, inverted repeats or Z-DNA forming sequences, are often hot spots for spontaneous , mutation.

We found that the deletion mutation of poly(dG)-poly(dC) sequence in E.coli cells occurs in a strikingly length-dependent manner; one base-pair difference in length determines whether the sequence deletes or not. These findings show that the deletion is mediated by dG.dG.dC triplex formation in contrast to the sequence slippage mismatching model. We also report that the recombination event triggered by a non-B DNA structure forming sequence is dramatically enhanced by active transcription of a downstream gene.

(1) Kohwi,Y. and Kohwi-Shigematsu,T. (1988) PNAS,USA 85, 3781.

(2) Kohwi-Shigematst', T. and Kohwi,Y. (1991) NAR 19, 4267-4271.

(3) Kohwi,Y. and Kohwi-Shigematsu,T.; submitted.

(4) Kohwi,Y., Malkhosyan,S. and Kohwi-Shigematsu,T.; submitted. 


\title{
Cellular Responses to Environmental DNA Damage
}

\begin{abstract}
Alkylating agents and SCE : Role of Biological and Technical Parameters. Dr. LAUURENT Christian ", Dr. COLligNON Joelle **, JADOT Pascal *, Goens Géraldine *, Rombout Sonia *. * Laboratory of Oncology, Radiobiology and Experimental Mutagenesis. ** Department of Hemato: Oncology University of Liège - Institute of Pathology B23 - B 4000 Sart Tilman - Beigium Europe
\end{abstract}

Recently, the Sister Chromatid Exchange assay has been introduced as a sensitive human monitoring technique for detecting previous human exposure to chemical mutagens. However, interpretation of obtained results may encounter some difficulties due to possible interference of technical and/or biological parameter.

After an in vivo exposure, the rate of increase in the SCE frequency may be correlated with che culture duration and may be dependent of the baseline SCE frequency of the concerned individual. '.

The present study was conducted to evaluate the biological response of lymphocytes - exposed in virro to MMC (which produce unrepaired lesions) and ENU (repaired lesions during G0 stage) - from 2 donors non exposed to rutigens and characterized by a large difference in their baseline SCE frequency (very low \& very high).

We documented a fairly clear difference between the donors induced SCE frequencies. The High SCE donor has significantly fewer induced SCE compared to the low SCE donor. In addition, we have shown that harvest time may affect dramatically the mean SCE frequency and therefore may be responsible for false negative results.

Our observations indicate that the simultaneous study of both parameters may provide an insight into the persistence of the genetic effects and should be taken into account for detection of DNA-lesions expressed cytologically by an increase in the SCE rate. Absence of biological response to a known mutagen might not always be related to absence of induced effects. 
"Cellul ar Responses to Environmentạ DNA Damage

Replication of Acetylaminofluorene Adducted Plasmids in Human Cells: Spectrum of Base Substitutions and Evidence of Excision Repair. M. Chia-Miae Mah, Janet Boldt, Veronica M. Maher, and J. Just in MeCormick, Carcinogenesis Laboratory, Michigan State University, East Lansing, MI 48824

In animals fed the liver carcinogen 2-acetylaminofluorene, the two most abundant types of DNA adducts, are $N$-(deoxyguanos in-8-y1)-2-acetylaminofluorene (dG-C8-AAF), and its deacetylated derivative, $N$-(deoxyguanosin-8-y1)-2aminofluorene (dG-C8-AF) A minor adduct is 3-(deoxyguanosin-N2-y1)-2acetylaminofluorene (dG- $\left.N^{2}-A A F\right)$. To investigate the mechanisms by which this carcinogen induces mutations in human cells, we treated a shuttle vector, pZ189, carrying the supF tRNA gene as target gene, with tritium-labeled $\mathrm{N}$-acetoxy-2: acetylaminofluorene (N-AcO-AAF) and analyzed the plasmid DNA for the initial number and kinds of DNA adducts using 32p-postlabeling, as well as their location in the supF gene, as determined by the DNA polymerase stop assay. The results showed that $85 \%$ of the original adducts were $d G-C 8-A A F$ and $15 \%$ were $d G-N^{2}-A A F$. The plasmids were then transfected into human cell line 293 and allowed to replicate. After $40 \mathrm{~h}$, the progeny plasmids were isolated and examined for the frequency and spectrum of mutations induced. The majority of the mutations were base substitutions (72/84), principally G०C $\rightarrow \rightarrow T \cdot A$ transversions. These mutation results were compared with what we found previousiy using this system : with plasmids treated with $N$-acetoxy-N-trifluoroacety $1-2$-aminofluorene to obtain dG-C8-AF adducts. In the latter study (Mah et al., Carcinogenesis, 10:2321, 1989 ), the majority of the mutations $(49 / 55)$ al so were $G \cdot C$ base substitutions, mainly $G \circ C-D T \cdot A$, but the acetylated adducts were much more mutagenic than the deacetylated adducts. The location of "hot spots". for mutations induced by acetylated adducts differed completely from those found with deacetylated adducts. There was good correlation between the sites of adduct formation and the sites of mutations, indicating that at least in part, the occurrence of mutational "hot spots" reflects the preferential binding of the carcinogen to" DNA. We also investigated the nature of the adducts at various times after: transfection into the human cells, and how many of them had been removed by human cellular DNA repair processes prior to DNA replication, using 32 p. postlabeling analysis. Following transfection of the plasmids into the human cells, there was no deacetylation of AAF adducts, and $85 \%$ of both types of adducts had been removed within $3.5 \mathrm{~h}$ after transfection, most probably by excision repair. The data indicate that the adducts remaining at the time of replication induced mutations with high efficiency. (This research was supported in part by DHHS Grant CA212153 from the National Cancer Institute to V.M.M.; and by scholarships from CAPES, Brazil to C.-M.M., and from the Deutsche Forschungsgemeinschaft of the German Federal Republic to J.B.; and by Contract 87-2 to V.M.M. from the Health Effects Institute.) 
"Cellul ar Responses to Environmental DNA Damage"

Spectra of UV-Induced Mutations Arising in the Coding Region of the Human Hypoxanthine (Guanine) Phosphoribosyltransferase (HPRT) Gene: Evidence for Preferential Repair of the Transcribed Strand. H. Glenn McGregor, Ruey-Hwa Chen, Lubov Lukash, Veronica M. Maher, and J. Just in McCormick, Carcinogenest's Laboratory, Michigan State University, East Lansing, MI 48824

To study the effects of nucleot de excision repair on the spectrum of

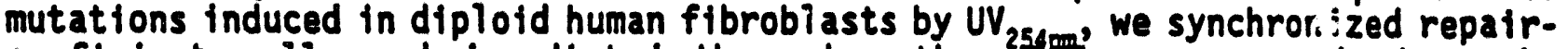
proficient cells and irradiated them when the 35 PfI' gene was about to be replicated (early $S$ phase) so there would be no time for repair in that gene before replication or in $G$, phase $6 \mathrm{~h}$ prior to $S$, and determined the kinds and location (spectrum) of mutations in the coding region of that gene. To control for chromatin accessibility factors during $S$ and $G$, we synchronized and irradiated XP cells from complementation group $A$, which have no ability to repair UV-induced damage, at these same two points in the cell cycle, and determined the spectra of mutations in the coding region of the HPRT gene. Forty-two repairproficient and 42 repair-deficient mutants were sequenced. Among the base substitutions derived, $G \cdot C \rightarrow A \cdot T$ transitions predominated, accounting for $58-$ 68\% of the total in cells that had no time or no ebility to repair. This percentage dropped to $47 \%$ in the repair-proficient cells irradiated in $G_{\text {. }}$-phase. The assumption that the premutagenic photoproducts resfonsible for the mutations involve dipyrimidine lesions allows one to assign ine strand that contained the original photoproduct. This kind of analysis of the mutants from cells which had no time or no ability to carry out excision repair indicates that $74 \%(34 / 4.6)$ of the lesions were located in the transcribed strand. With mutants derived from normal cells irradiated in $G_{1}$, and allowed at least $6 \mathrm{~h}$ for repair prior to onset of S-phase, only $20 \%(3 / 15)$ of the lesions were located in that strand. The data suggest that nucleotide excision repair preferentially removes UV-induced lestons from the transcribed strand of the HPRT gene. No switch in strand bias was seen in excision repair-deficient XP cells, supporting this concluston. Radioimmunnassays indicate that 6-4 photoproducts are removed within $6 h$, but the majority of the cyclobutane dimers remain. The fact that the proportion of G०C $\rightarrow A \circ T$ transitions was lower in the repair-proficient cells that had been allowed $6 \mathrm{~h}$ for repair before $S$ phase suggests that $6-4$ photoproducts preferentially cause such transitions. We are currently investigating strand-specific repair of the HPRT gene in XP cells that have intermediate exciston repair capacity. (This research was supported by Department of Health and Human Services Grant CA21253 from the National Cancer Institute and by a grant to WGM from Chevron/Society for Risk Analysis.) 


\section{Cellular Responses to Environmental DNA Dawage}

Strand-Specific Mutagenesis Linked to Replication. Wilziam B. Melchior, Jr., Laure A. Lindsey, and Prederick A. Beland, National Center Lor Toxicological Research, Jefferson, Arkansas 72079, U.S.A.

Strand-specific mutagenesis has been demonstrated in both bacterial and eukeryotic systems. Typically, more mutations are observed on the nontranscribed strand, a fact that has been attributed to preferential repair of DNA damage on the transcribed strand. Bowever, in pBR322 modified with 1-aminopyrene, mutations occur to a greater extent on the transcribed strand. Th1s suggests that other factors, such as differences in the fidelity of replication between the two strands, may contribute to strand-specific mutagenesis. In order to examine this possibility, mutation induction was examined in the tetracycline-resistance gene of two plasmids modified with 1-aminopyrene. In the first plasmid, PBR322, the gene is transcribed in the direction opposite to leading-strand replication, while the second plasmid, PRT0101, vas created from PBR322 with the entire tetracycline-resistance gene and its promoter in the opposite orientation, so that the gene is transcribed in the same direction as replicktion. Pollowing modification of a defined region of the gene with 1-aminopyrene, the plasmids vere used to transform SOS-Induced E. coll. Tetracycline-sensitive mutants vere then selected and the DNA sequence changes vere determined.

Vith PBR322, the guanine residue, which vas assumed to be the site of DNA: adduction, was located on the transcribed strand in 20 of 31 1-aminopyreneInduced mutants (about 2/3). With pRT0101, 14 of 21 mutants (again 2/3) occurred with the guanine on the nontrainscribed strand. Thus, when the orientation of the gene was changed relative to the direction of replication, the strand preference for mutagenesis also changed.

These results clearly show that in $\mathrm{E}$. coll there can be a coupling between replication and strand-specific mutagenesis. The mechanism of this replication dependence remains to be determined, but it could be due to different fidelities of leading- and lagging-strand replication or to differences in rates of replication-coupled repair between the two strands. Another possibility is that replicative bypass of 1-aminopyrene adducts may occur more easily on the leading strand, which would lead to preferential fixation of mutations on this strand. 

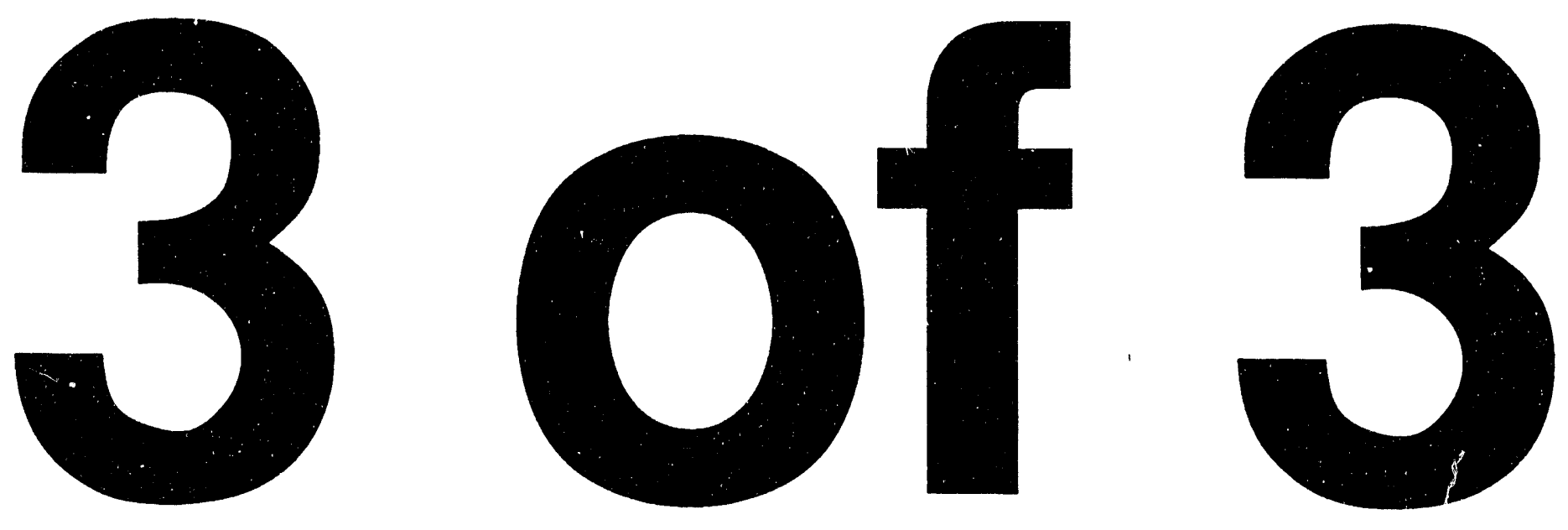
A Single-Stranded Shuttle Vector for Mutagenesis Study in Mammalian Cells: 8Oxodeoxyguanosine Causes G $\rightarrow$ T Transversions in Monkey Kidney Cells, Masaaki Moriya, Department of Pharmacological Sciences, State University of New York at Stony Brook 11794-8651

Cellular DNA is continuously damaged by reactive oxygen species generated by endogenous cellular oxidative processes, ionizing radiation, chemical oxidants and carcinogens. Damage to DNA may be a significant source of mutations, cancer, aging and aging-related diseases. 2'-Deoxy-7,8-dihydro-8-oxoguanosine (8-0xodG), a product of the oxidative DNA damage, is found in DNA of various organs in significant amounts. 8-OxodG has been reported to be miscoding in in vitro DNA synthesis systems and a weakly mutagenic lesion causing $G \rightarrow T$ transversions in $E$. coli. To study the mutagenic potential of this lesion in mammalian cells, a single-stranded shuttle vector system has been developed, in which a single defined lesion is introduced site-specifically. Efficiency of translesional synthesis is determined by the number of neomycin-resistant colonies in experiments using COS cells and of ampicillin-resistant colonies in experiments with $E$. coli. Fidelity of the synthesis is evaluated by analyzing the nucleotide sequence corresponding to the adducted area of progeny plasmid. The system permits us to detect non-mutagenic as well as mutagenic translesional synthesis. 8-OxodG did not inhibit substantially the translesional synthesis in $E$. coli and COS cells. The lesion induced targeted $G \rightarrow T$ transversions at a frequency of $3.1 \%$ in the COS experiments, which was similar to $2.2 \%$ in the $E$. coli experiments carried out simultaneously. 
ABSTRACT Submitted for AACR Special Conference: Cellular Response to Environmental DNA Damage.

EVIDENCE FOR DNFLUENCE OF POSTIRRADIATION CELL PROGRESSION ON HPRT MUTATION LESION SPECTRUM.

Frank Ngo, Jia Xian Li, Indira Kalvakolanu, Mark Galinski, and Sipra Banerjee. Laboratory of Radiation Biology and Department of Molecular Biology, Cleveland Clinic Foundation, Cleveland, Ohio 44195, USA.

We have previously shown that when Chinese hamster cells were irradiated in plateau G1 phase with gamma rays, the HPRT mutation frequency varied depending on the length of incubation time and the associated cell proliferating states postirradiation (Ngo et al. Workshop on Oncogenic Mechanisms in Radiation-Induced Cancer, Fort Collins, Colorado, 1991). In this study, two repair processes were noted. The first occurred within the initial few hrs while cells were in G0 and GI and appeared to be independent of cell proliferation. The second process took place as cell progressed through $\mathbf{S}$ phase. These repair processes were inferred by the reduction of the mutation frequency. Further, the S-phase but not the G1 phase repair was markedly suppressed by treatment of the irradiated cells with aphidicolin, an inhibitor of DNA polymerases $\alpha, 8$, and e, or 6-mercaptopurine ribonucleoside, an inhibitor of 3'-5' exonuclease, during the repair incubation. These findings together with our earlier work on DNA strand breaks and rejoining have prompted us to theorize that the S-phase repair process may reflect the proofreading functions of endogenous DNA polymerases and/or exonuclease. To investigate the types of mutational lesions that the S-phase repair is capable of handling, we have isolated HPRT mutants that are derived from (a) immediately postirradiation, and (b) $6 \mathrm{hrs}$, and (c) $15 \mathrm{hrs}$ of incubation after irradiation at G0/G1. Flow cytometry data indicated that cells in groups $\mathrm{a}, \mathrm{b}$, and $\mathrm{c}$ were at G1, G1/S, and mid or late S, respectively. Using PCR amplification of the nine exons and their associated franking regions in the HPRT gene, we have characterized the mutational lesions in mutants of groups a and $c$. We found that about half $(5 / 11)$ of the mutants in group a exhibited total gene deletion (no detectable exons), whereas in group c most mutants contained point mutations $(8 / 11)$ and the remaining mutants contained single-exon deletions (2/11), and multiple-exon deletions (1/11). Surprisingly, none of the group c mutants, which presumably have had experienced both $G 1$ and $S$ repair processes, contained total gene deletion. This may be attributed to a preferential repair of lesions with large gene deletion. Such a repair would require a post-replication recombinant pathway. The lesions presented in the group b mutants, to be characterized, may help clarify this. Alternatively, this might be explained if potential mutants which contain large deletions could not survive during cell progression, and, if so, a damage fixation mechanism would need to be invoked. These results and other detailed study of the transcriptional function of the mRNA in these mutants will be presented. 
"Cellular Responses to environmental dNa damage"

Role of radical species in the mutagencity of Agaricus bisporus.

Christina Papaparaskeva. Costas Ioannides and Ron Walker, Division of Toxicology, School of Biological Sciences, University of Surrey, Guildford Surrey, GU2 5XH, UK.

The extensively consumed mushroom Agaricus bisponus has been shown to be tumorigenic in mice, when fed raw at high amounts. It gives rise to tumours in the forestomach, bone, lung and liver. Moreover, ethanolic extracts of this mushroom species display a direct-acting mutagenicity in the Ames test using various Salmonella typhimurium strains. Incorporation of an activation system derived from the liver of control and Aroclor 1254-induced rats or control mice did not enhance the mutagenic response. The hydrazide agaritine was considered as the possible mushroom constituent mediating the carcinogenicity and mutagenicity of this fungus. However, agaritine was not carcinogenic when administered to the same strain of mice. Moreover, no correlation was obtained between agaritine content of various types of mushroom and the mutagenicity of their enthanolic extracts (Papaparaskeva et al, 1991). In our studies we observed that of the various Salmonella tynhimurium strains, TA 104 was by far the most sensitive to the mutagenicity of this fungus. TA 104 is sensitive to oxidative mutagens and this raises the possibility that such species may be important contributors to mushroom mutagenicity. Indeed, the radical scavenger DMSO decreased the mutagenicity of mushroom extracts in TA 104 in a concentration-dependant manner. Moreover, the enzymes that detoxicate active oxygens species, catalase and superoxide dismutase, caused a marked decrease in the mushroom mutagenicity. Addition of rat hepatic cytosolic fraction, in the presence of an NADPH-generating system, markedly potentiated the mutagenic response. The cytosol-mediated potentiation of the mutagenicity of mushrooms was not inducible by previous treatment of rats with Aroclor 1254. Finally, the cytosolic-mediated activation of the ethanolic mushroom extract was inhibited by DMSO, catalase, superoxide dismutase and the diaphorase inhibitor dicoumarol. These findings implicate radical species in the mutagenicity of Agaricus bisponus.

C Papaparaskeva, C Ioannides and $R$ Walker (1991). Agaritine does not mediate the mutagenicity of the edible mushroom Agaricus bisporus. Mutagenesis 6: 213:217. 
Cellular Responses to Environmental DNA Damage

Induction of Mutations with Salt in Growing Cells of Yeast, Kenneth R. Parker and R.C. von Borstel, Dept. Genetics, University of Alberta, Edmonton, Canada T6G 2E9

It has been shown that monovalent and divalent salts induce mutations in the yeast Saccharomyces cerevisiae (Parker and von Borstel, 1987). We reported that mutations can be increased by at least a factor of fifty by immersion of logarithmically growing cells into 1 or 2 molar salt solutions. As measured by reversion analysis, both frameshifts and base substitutions are induced. The mutations are induced as a function of molarity.

Now we have found that cells which undergo growth in low concentrations of salt $(0.6 \mathrm{M}$ or less) also mutate, and the mutagenic effect is salt-dependent, not molarity dependent. That is, salts of the same molarity and osmolality do not induce mutations with identical effectiveness. At a concentration of $0.3 \mathrm{M}$ sodium chloride, cells growing in salt have altered mutational spectra in two distinct ways: (1) The types of mutations observed differ, e.g., some suppressor mutations observed in the control do not permit cell replication in the salt, and (2) the mutation spectrum appears to be shifted so that frameshift mutations occupy a higher proportion of the total mutations observed.

\section{Literature Cited}

Parker, K.R., and R.C. von Borstel, 1987, Base-substitution and frameshift mutagenesis by sodium chloride and potassium chloride in Saccharomyces cerevisiae, Mutation Research 189: 11-14. 
Cellular Responses to Environmental DNA Damage

Transgenic Mouse Models to Study Mutagenesis In Vivo. Bradley D. Preston and Sandy Price, Laboratory for Cancer Research, Ruigers University College of Pharmacy, Piscataway, NJ 08855-0789.

Mutations play a critical role in the etiology of cancer, heritable diseases, and possibly aging. Studies in cells in culture demonstrate that DNA damage and repair are important modulators of mutagenesis. However, the action of these processes in vivo and their abilities to modulate disease are not clear. To better characterize cellular responses to DNA damage in whole animals and to understand the contribution of spontaneous and induced mutations to disease, we are studying mutagenesis in transgenic mice. Our approach is to study mutations in $E$. coli replication vectors inserted into the genomic DNA of inbred mice. We have focused on 5 vectors in which mutations can be quantified and sequenced following rescue in E. coli. Two of these vectors (p201 and M13mp2) allow the detection of forward mutations in the thymidine kinase and lac $Z \alpha$ genes, respectively, while three vectors ( 6 X174 am3, M13mp2 A89 and M13G*1) are based on reversion assays in bacteriophage 6 X174 and M13 that detect all 6 possible base-substitution mutations at defined DNA sites. The advantage of these latter vectors is their low spontaneous mutation frequency $\left(<10^{-6}\right)$ and thus high sensitivity for scoring mutations. Six transgenic founder mice harboring the p201, M13mp2, $\varnothing$ X174 am3, $\varnothing$ X174 wild-type or M13mp2 A89 vectors were created by pronuclear microinjection of linearized DNA into fertilized F2 eggs from crosses of (CS7BL/6 $\times$ CBA)F1 mice. The number of transgenes per diploid genome range from about 2 to 30 as determined by Southern blot analyses. Four founder mice ( $\varnothing \mathrm{X} 174 \mathrm{am} 3, \varnothing \mathrm{X} 174$ wild-type and two M13mp2 A89 founders) have been bred and expanded into stable transgenic mouse lines in (C57BL/6 $\times$ CBA)F1 crosses as well as in pure CBA and C57BL/6 genetic backgrounds. A procedure using the polymerase chain reaction and selective hybridization was developed to rescue transgenes for expression in E. coli. Control experiments on the $\phi \times 174$ wild-type mice demonstrate that about 106 independent transgene copies can be rescued from $2.5 \times 106$ somatic cells. These transgenic animals are currently being used to compare the frequencies and types of mutations arising in tissues with different carcinogen susceptibilities and in carcinogen-sensitive and -resistant genetic backgrounds. These studies will help identify carcinogenic DNA lesions and better characterize mechanisms of DNA damage and repair in whole animals. 


\section{"Cellular Responses to Environmental DNA Damage"}

Tissue Specific Mutational Responses to MNO in B6C3/F1 Transgenic Mice. aGeoffrey $s$. Provost, asteven W. Rohler, ARichard T. Bamner, aBrenda J. Rogers, acrystal D. Matthews, bonald I. Putman, and aJay M. Short. astratagene cloning Systems, Ia Jolla, CA. and Microbiological Associates Inc.. Rockville MD.

Transgenic B6C3/F1 mice containing a lambda phage shuttle vector carrying a lacI target gene and alacz reporter gene were developed for in vivo mutagenesis testing. Following chemical treatment of the animals, the DNA is isolated and the shuttle vector is recovered by exposing the genomic DNA to in vitro lambda phage packaging extracts. These extracts package the shuttle vector into viable phage particles capable of infecting E.coli and forming plaques on the bacterial lawn. Mutations in the lacI target gene inactivate the repressor protein allowing transcription and expression of the alacz reporter gene. When plated on agar containing the chromogenic indicator $x$-gal, mutant phage form blue plaques while non-mutant remain colorless. This transgenic system was used to measure the mutant frequency of $N$-methyl-N-nitrosourea (MNU) with respect to time after dosing. Twelve 6 to 8 week old male mice were given IP injections of $100 \mathrm{mg} / \mathrm{kg}$ body weight at 5 consecutive 24 hour intervals. Three additional mice were injected with phosphate buffer as a control. Animals were sacrificed at $1,3,6$, and 12 days after the final injection.: Three animals' were sacrificed at each time point. DNA was prepared from spleen, lung, liver, brain, and a purified population of germinal cells from these animals and assayed for mutations. Mutant frequencies from these animals demonstrated a time dependant and tissue specific response. As much as a 74 fold induction over background was observed in the spleen of animals sacrificed 12 days after final dosing. Conversely, mutations in the brain showed only a 2 to 3 fold induction over control animals regardless of time after dosing. This tissue specific mutagenic effect correlates with the proliferative index of the tissue being tested. Determining the mutational spectra by sequencing a subset of these mutations is facilitated by the use M13 helper phage and partial filamentous phage origins present on the shuttle vector which allows excision of the target gene into a plasmid. The majority of mutations were $G: C$ to A:T transitions occurring at GPG dinucleotides, consistent with the mechanism for MnU mutagenesis. 
The split-end model for homologous recombination at double-strand

\title{
breaks and at Chi
}

\author{
Susan M. Rosenberg*1 and P. J. Hastings \\ Deparment of Genetics, University of Alberta, Edmonton, Alberta T6G 2E9, Canada, 1permanent \\ address: Cross Cancer Instinute, University of Alberta Medical School, 11560 University Avenue, \\ Edmonton, Alberta T6G 1Z2, Canada.
}

Two different styles of model for homologous recombination have been widely used to explain recombination events associated with, or far from, double-strand breaks in DNA. The models of Holliday and Meselson and Radding exemplify those that do not involve a break whereas the model of Szostak et al. is an example of those that do. Recent advances in understanding a recombination system thought to promote exchange distant from DNA ends, at Chi sites, suggest a mechanism of initiation neither like Holliday/Meselson-Radding nor like Szostak et al. In those models, only one strand of DNA may invade a homologous DNA molecule. We propose a model for Chi in which exonuclease degrades DNA from a double-strand break to the Chi site; the exonuclease is converted into a helicase upon interaction with Chi; unwinding produces a recombinagenic split-end, and both 3'- and 5'-ending strands at the splitend are capable of invading a homologue. Different genetic consequences are proposed to result from invasion by each. Genetical and bicchemical evidence for the model is presented, and novel predictions are noted. We suggest that recombination at double-strand breaks in other systems is effected by helicase producing a recombinagenic split-end, either or both strands of which can invade a homologous chromosome. We propose that $3^{\prime}$ overhangs resulting from $5^{\prime}$ to $3^{\prime}$ exonucleases, so common in other recombination systems, exist to enhance the fidelity of recombination and to help direct both strands at the splitend to invade the same molecule. The split-end model provides a possible mechanism for initiation of meiotic and mitotic recombination in fungi. We argue that eukaryotes including mammals possess recombination systems similar to the Rec system and Chi.

* Author presenting paper. 
"Cellular Responses to Environmental DNA Damage"

8-Methoxypsoralen plus UVA-induced mutations in a mammalian gene are highly targeted at sites of photoadducts, Evelyne SAGE, Elliot DROBETSKY, Marc BERNARD and Ethel MOUSTACCHI, CNRS URA 1292, Institut Curie-Biologie, 26 rue d'Ulm, 75005 Paris, France

The probability that DNA damage will be converted into an heritable mutation is influenced by a number of factors related to its DNA context. These include the frequency and distribution of premutagenic lesions, and the relative efficiencies of various DNA repair pathways at particular sites. In order to better understand the respective contribution of these different parameters to mammalian cell mutagenesis, the mutational specificity of 8-methoxypsoralen (8-MOP) plus UVA was determined at the endogenous APRT (adenine phosphoribosyluransferase) locus in CHO cells. 8-MOP reacts mainly with thymine to form furan-side and pyrone-side monocycloadducts as well as biadducts leading to interstrand crosslinks. The distribution of photoadducts induced in vitro in the same target gene was also studied. Photoadducts were detected almost exclusively at sites previously shown to be crosslinkable, i.e. 5'TpA located in AT-rich sequences (Sage \& Moustacchi, Biochemistry 26, 1987, 3307-3314). Of 18 mutant APRT alleles thus far characterized at the DNA sequence level ( $12 \%$ survival level), all occurred at such sites of damage. Only single base substitutions were recovered, exclusively at $T$ residues (10 T->A, $6 \mathrm{~T}->\mathrm{G}, 2 \mathrm{~T}$ $>C$ ). The data are consistent with preferential repair of the transcribed strand, i.e., all of the mutantz could have resulted from damage persisting on the non-transcribed strand. Although this interpretation may certainly be valid in the case of premutagenic monoadducts, the observed strand bias may also be explained in terms of the mechanism of crosslink repair. 


\section{"Cellular Responses to Environmental DNA Damage"}

Nonmutagenic carcinogens indure intrachromosomal recombination in yeast. Robert $\mathrm{H}$. Schiestl, Department of Molecular and Cellular Toxicology, Harvard University, School of Public Health, 665 Huntington Ave. Boston, MA 02115.

A large number of animal and human carcinogens without apparent genotoxic activity exist (nonmutagenic carcinogens) which are difficult or impossible to detect with the currently used short term tests. For instance the Ames assay, has been recently reported to detect only about 50\% of the carcinogens. It is important to find and characterize model systems which can define the biological activity of these nonmutagenic carcinogens.

Carcinogenesis is in many cases associated with genome rearrangement. Because of this association, a system selecting for ir-achromosomal recombination which results in genome rearrangement has been constructed in the yeast Saccharomvces cerevisiae. A plasmid with an internal fragment of the HIS3 gene has been integrated into the HIS3 locus resulting in two copies of the HIS3 gene, each having one terminal deletion. This construct reverts to HTS3+ by recombination of the two his 3 deletion alleles. Plasmid excision and sister chromatid exchange were found not to be involved in reversion of the his 3 disruption. This recombination event deletes the entire integrated plasmid and has been termed deletion (DEL) event.

DEL recombination is under different geretic control than is interchromosomal recombination and meiotic recombination and therefore is probably due to a different mechanism. It has been shown that mutations in the DNA repair genes RAD1 and RADS2 each affect the DEL recombination; interchromosomal and meiotic recombination is only affected by mutations in RADS2, but not by mutations in RAD1.

It has been found that DEL recombination is readily inducible by 10 mutagenic carcinogens and 16 nonmutagenic carcinogens which are not detectable (false negatives) with the Ames assay (Schiestl, R.H. (1989) Nature 337:285-288). In addition, three out of four mutagens which do not cause cancer (false positives in the Ames assay) do not induce the DEL assay.

Further characterization of the miechanism involved in induction of DEL recombination may contributs to the understanding of the biologic activity of these nonmutagenic carcinogens since DEL recombination is the only genotoxic effect some of these agents show. This knowledge may further be used to improve the DEL assay. Since DEL recombination is UV-, EMS- and MMS-inducible in the rad1 mutant but not in the rad52 mutant the RAD52 pathway seems to be required for the induction. Furthermore the inducibility in a radi mutant is better than in the wildtype and therefore allows more sensitive detection of the above agents. DEL recombination is inducible only in the S or G2 phase of the cell cycle but not in the G1 phase. Interchromosomal recombination on the other hand is inducible in G1 but not in G2. Therefore DEL recombination seems to be due to interactions between sister chromatids.

The DEL assay is inexpensive, gives results in as little as four days, is easy to perform requiring only minimal training and equipment, is highly reproducible and avoids the growing concern about animal testing. If after further testing the results obtained with the DEL assay show a high positive correlation with the cancer causing activity of the test agents, the DEL assay should be useful as a short term test to identify mutagenic as well as nonmutagenic carcinogens. 
Cellular Responses to Environmental DNA Damage.

Mechanisms of Radiation-Induced Gern-Cell Mutagenesis as Revealed by the Specific-Locus Test Systen Using the Japanese Medaka. Akihiro Shima, Atsuko Shinada and Yoshiko Kubota, Laboratory of Radiation Biology. Zoological Institute. Faculty of Science, University of Tokyo, Bunkyo-ku, Tokyo 113, Japan.

Te have recently succeeded in developing a nonmamalian test systea to study environmental germ-cell mutagenesis using a flsh, the Japanese Medaka (Shima Shimada, PNAS.. 88:2545-2549, 1991). This system tias first quantitatively demonstrated that, irrespective of maturation stage of the male germ cells. 1.e. sperm, spermatids or spermatogonia, at the time of exposure, alnost $90 *$ of the spontaneous as well as radiation-induced mutants which are phenotypically detectable at early developnent ( "total nutations" ) died during subsequent developaental process. We then named those nutants which can survive to sexual maturity at which they are subjected to test crossing "viable nutations". The Medaka data accumulated by the past 7 years' study on dominant lethals and viable specific-locus mutations are quite comparabie to those established for the mouse. The specific outcome from our Medaka test systen is the finding that a great majority of the total mutants are eliminated during embryonic development, suggesting that the induced specific-locus mutations are associated with wutations more than the specific locus, presumably multilocus deletions, which are primarily responsible for the dosinant lethals. In order to substantiate these basic mechanisns of germ-cell mutagenesis, we first established a nethod to cultivate soatic cells from each embryo when they becone moribund, and to extract genomic DNA. The relatiohship between the Induction of nutations and/or malformations and changes in genomic DNA as revealed by RFLP and/or fingerprints generated by the AP-PCR is presented. 
Cellular Responses to Environmental DNA Damage

Aflatoxin B1 mutagenesis of the pS189 shuttle vector in human cells expressing the rat liver P450IA2 cDNA. Yvon Trottier, William 1. Waithe and Alan Anderson. Centre de recherche en cancerologie de l'Universite Laval, l'Hotel-Dieu de Quebec, Quebec G1R2J6.

Cytochrome $\mathrm{P} 450$ s catalyse the in vitro oxidative conversion of many promutagens and procarcinogens into setive metabolites and are thought to play the same role in vivo. The transient expression of cytochrome P450 CDNAs in mammalian cells provides a new tool to study the role and specificity of individual $\mathrm{P}^{4} 5 \mathrm{O}$ s in the activation of procarcinogens. An example of such a procarcinogen is the occasional food contaminant aflatoxin B1 (AFB1) which can be converted by oxidative mietabolism to a mutagenic metaboiite (2,3-epoxide) which binds preferentially to the N7 position of guanine in DNA. We decided to combine the specificity inherent in transient CDNA expression of an individual cytochrome P450 with the use of a shuttle vector to examine the types of mutations caused by the activation of AFB1 in a human cell line.

Ad293 cells were first transfected with P91-IA2, a rat liver P450IA2 CDNA expression vector, or with P91-IA2(i) (2 control vector having the P450 cDNA in the inverted orientation) and incubated for $24 \mathrm{~h}$ ' to permit P450IA2 accumulation. The presence of active P450IA2 was confirmed by the ability of homogenates of p91-IA2-transfected cells to convert MeIQ (2-amino3,4-dimethylimidazo[4,5-f] quinoline) into mutagenic metabolites in the Ames Salmonella test. p91-IA2-and p91-LA2(i)-transfected cells were transfected with the pS189 shuttle vector plasmid, which carries the Escherichia coli supF gene as a mutational target, and incubated for a further $24 \mathrm{~h}$ in the presence of AFB1 at $0.5,1$ or $2 \mu \mathrm{g} / \mathrm{ml}$ to permit activation of AFB1 and pS189 replication. Marked cytotoxirity was evident in AFB1-treated cells transfected with P91-IA2 but not in those transfected with p91-IA2(i). pS189 was recovered from transfected cells and transformed by electroporation into E. coli MBM7070 (lacZam). Lac colonies (white or light blue) were identified on ampicillin/X-Gal plates and the mutant supF genes of their pS189 plasmids were sequenced. In shuttle vectors replicated in p91-LA2-transfected cells, there was a striking increase in the supF point mutation frequency with increasing concentrations of AFB1. This frequency was 9 to 26 times greater than the background point mutation frequency obtained with AFB1-treated control (p91-IA2(i)-transfected) cells. The large majority (88\%) of AFB1induced supF mutants had base substitutions, most of which were G:C to T:A transversions. This mutagenesis system permits the molecular analysis of mutations induced in human cells by specific P450/promutagen pairs and will permit the investigation of host cell mechanisms involved in the generation of these mutations. 


\section{Cellular Responses to Environmental DNA Damage}

Origin of Hotspots for Mutations Induced by Ultraviolet Radiation in Yeast, R.C. yon Borstel and Grace S.-F. Lee,

. Dept. of Genetics, University of Alberta, Edmonton, Alberta, Canada T6G 2E9

James, Kilbey, and co-workers, by pedigree analysis and mutationinduction kinetics, showed that whole colony mutants induced by ultraviolet radiation in a DNA-repair-proficient strain of yeast require formation of two dimers, both within apposed excision fragments (cf. von Borstel and Hastings, -1985). From these considerations it can be deduced that UV-induced hotspots could arise if more than one opportunity avails for pyrimidine dimer formation in opposite strands of the DNA molecule within the excision-repair framework. Moreover, if there is no opportunity for a pyrimidine dimer to appear in the opposite strand within an excision-repair segment, there will be no UV-induced mutations in a region where either spontaneous or chemically induced mutations do appear. The intermediate situation would be for one or two dimers in each of the strands to be accessible for dimer induction by ultraviolet light.

At exposures to ultraviolet radiation where mutations are induced by two quantum events, there are three major hotspots in the URA3 gene of yeast, one of which is photoreversible, and the other two not (Lee and von Borstel, submitted). The hotspots are located at sites 268, 242, and 701 in the URA3 gene; only the first one is on the transcribed strand. Two "tepid" sites were chosen for comparison because they are similar in base composition to the sites for hotspots, and one of them, at site 22, was induced in a cell during logarithmic growth phase, and the other, at site 769, was induced in a cell in stationary phase. The remaining mutant for this comparison, a coldspot at site 427, was induced by methyl methanesulfonate (Lee et al., in press): therefore we know this region is mutable although no UV-induced mutation has ever been induced there.

The results show that there is no pyrimidine doublet in the opposing excisable fragment for the coldspot, and that there is an increase of pyrimidine doublets and triplets as the chances for mutations increase. Moreover, in the region where the hotspot exists, there are numerous mutations as near neighbors of the hotspot. The hypothesized phenomena leading to hotspots, tepidspots, and coldspots are thus supported by experimental evidence. The results demonstrate the validity of the model of multiple pyrimidine doublets in overlapping excisions as an explanation for UV-inducible mutational hotspots in yeast.

\section{Literature Cited}

Lee, Grace S.-F., and R.C. von Borstel, The base alterations induced in yeast by ultraviolet radiation followed by photoreactivating light, Mutation Res. (submitted).

Lee, G. S.-F. K.S. Blonsky, D. Lee Van On, E.A. Savage, A.R. Morgan, and R.C. von Borstel, Base alterations in yeast induced by alkylating agents with differing Swain-Scott substrate constants, J. Mol. Biol. (in press).

von Borstel, R.C., and P.J. Hastings, 1985, Situation-dependent repair of DNA damage in yeast, In Basic and Applied Mutagenesis (Amir Muhammed and R.C. von Borstel, eds.), Plenum Publishing Corporation, New York, pp. 121-145. 
"Celluilar Responses to Environmental DNA Damage"

DNA sequence analysis of $N$-ethyl-N-nitrosourea-induced hprt mutations arising in vivo in $T$. lymphocytes of B6C3F1 mice. Vemon E. Walker, Judith E. Cochrane, Teresa R. Craft, and Thomas R. Skopek, University of North Carolina, Chapel Hill, NC 27599

An in vivo mutational spectra assay using a native gene of mice could facilitate interpretation of similar studies in humans and lead to improved assessment of human health risk from exposures to genotoxic agents. We have refined the mouse splenic T-lymphocyte cloning assay, as developed by Jones and coworkers (Mutat. Research 147:97-105, 1985), to determine both the quantitative and qualitative nature of mutations induced in hprt of T-cells from B6C3F1 mice. We have isolated hprt lymphocytes resistant to 6-thioguanine following treatmemt of 9-week-old male mice with $40 \mathrm{mg} / \mathrm{kg}$ N-ethyl-N-nitrosourea (ENU) by single intraperitoneal injection. In spleens removed six weeks after treatment, the T-cell mutant frequency was $78 \times 10^{-6}$. We have designed PCR primers which specifically amplify the exon 3 region of hprt in mouse genomic DNA, and are developing new techniques based on denaturing gradient gel electrophoresis (DGGE) a) to recognize which mutants possess mutations in exon 3 and $b$ ) to isolate pure mutant DNA for sequence aralyeis. We are currently using these techniques to determine the mutational spectrum inducei by ENU in T-cells of exposed mice. PCR-amplified DNA from 3 spontaneously-arising and nearly 200 ENU-induced hpri mutants were allowed to form heteroduplexes with wild-type DNA and then run on denaturing gradient gels. DGGE analysis revealed that 30 ENU-induced mutants had mutations in the lowtemperature melting domain of exon 3. So far, the mutant-containing bands from 28 ENU-induced mutants have been excised from gels, PCR amplified, and sequenced. Of these 28 ENU-induced mutations, 7 were GC to AT transitions occurring at base pair 17. These 7 mutations were obtained from several independent mice, suggesting that this site is a true "hotspot" for ENU-induced mutagenesis. All of the other ENU-induced mutations, except one, were at AT base pairs. One GC to TA transversion occurred in tandem with a AT to CG transversion, but may not be an ENU-induced mutation because the transversion at the AT base pair was observed as an independent mutation in a different mouse. A recurring AT to $O G$ transversion that produced a unique $C$ fr101 restriction site was seen in 12/28 ENU-induced mutants. However, 11 of these mutations occurred in the same mouse indicating that they originated from a clonal run. These preliminary results indicate that methods based on DGGE can be used to establish a generic in vivo model for studying the mechanisms and sequence specificity of mutagenesis in a native transcribed gene of experimental animials. 
"Cellular Responses to Environmental DNA Damage"

Xeroderma Pigmentosum Variant Cells Are Less Likely than Normal Cells to Incorporate dAMP Opposite Photoproducts during Replication of UV-Irradiated Plasmids. Yi-Ching Wang, Veronica M. Maher, and J. Justin McCormick, Carcinogenesis Laboratory, Michigan State University, East Lansing, MI 48824

Xeroderma pigmentosum (XP) variant patients show the clinical characteristics of the disease, with increased frequencies of skin cancer, but their cells have a normal, or nearly normal, rate of nucleotide excision repair of UV-induced DNA damage and are only slightiy more sensitive than normal cells to the cytotoxic effect of UV radiation. However, they are significantly more sensitive. than normal cells to the mutagenic effect of UV. Unlike excision repairdeficient XP cells, XP variant cells do not show this hypermutability with the bulky mutagen 7,8-diol-9,10-epoxide of benzo[a]pyrene. One possible explanation for the hypermutability with UV is that when XP variant cells replicate DNA containing UV photoproducts, their polymerases introduce replication errors more frequently than do those of normal cells. To test this hypothesis, we transfected an XP variant cell line with a UV ${ }_{254}$-irradiated shuttle vector, pS189, carrying the supF gene as a target for mutations and allowed replication of the plasmids in the variant cells. After $44 \mathrm{~h}$, we isolated the progeny plasmids and determined the frequency and spectrum of mutations induced. The results were compared with those obtained previously by Bredberg et al. (PNAS, 1986, 83:8273) when similarly-irradiated plasmids carrying the same targ-t gene replicated in a normal human cell line. The frequency of supF mutants increased: linearly as a function of UV dose to the plasmid, with a slope five times steeper ? than that seen with normal cells. DNA sequencing analysis of the supF gene in. mutant plasmids showed that 52 out of 53 independent mutants generated in the XP variant cells contained base substitutions, with some exhibiting more than one substitution per plasmid. The majority $(62 / 64)$ of the substitutions involved a dipyrimidine. $28 \%$ of these mutations involved $A \cdot T$ base pairs, with the majority found at position 136, a site located in the middle of a run of three $A \cdot T$ base if pairs. (In the normal cells, only $11 \%$ involved A०T base pairs.) These data; suggest that XP variant cells are less likely than normal cells to incorporate : dAMP opposite bases involved in photonroducts. This could explain the UV hypermutability if, as assumed, the rate of excision of lesions from the supF gene in the XP variant cell lines is equal to the rate in the normal cell line used by Bredberg et al. Studies are underway to determine if decreased frequency at incorporation of dAMP opposite photoproducts al so occurs during replication of the endogenous HPRT gene following UV irradiation of diploid XP variant cells. If so, this could account for the observed hypermutability of these cells with UV irradiation. (This research was supported in part by Department of Health and Human Services Grant CA21253 from the National Cancer Institute.) 


\section{Cellular Responses to Environmental DNA Damage}

Immuno-detection of Chromosomally Encoded Umu Mutagenesis Proteins in Enterobacteria.

Chao Ho, Arthur S. Levine and Roger Woodgate.

Section on Viruses and Cellular Biology, National Institute of Child Health and Human Development, Bethesda, MD 20892.

SOS mutagenesis in prokaryotes is dependent upon the inducible activity of the chromosomally encoded UmuDC proteins, or functionally homologous proteins such as MucAB or ImpCAB which are found on naturally occurring plasmids. We have utilized standard immuno-detection assays, coupled with a sensitive chemiluminescence detection assay, to probe chromosomally encoded Umu proteins from various strains of enterobacteria. Detection of the chromosomally encoded Escherichia coli Umu proteins has allowed us, for the first time, to directly measure cellular steady-state levels of these proteins under vanous SOS inducing conditions. UmuD was present at $\sim 180$ copies per uninduced cell and was measured at -2400 copies per cell in strains that lacked a functional repressor. Induced levels of UmuC were approximately 12 -fold lower than UmuD, with -200 molecules per cell. These levels of cellular UmuC protein suggest that it functions through specific protein-DNA or protein-protein interactions, possibly as a lesion recognition protein or by interacting with DNA polymerase III.

Relative to $E$. coli, a number of enterobacteria, including Salmonella typhimurium, are much less responsive to the mutagenic effects of DNA-damaging agents. It has previously been hypothesized that the weakly mutable phenotype is due to the absence of Umu proteins. To test this hypothesis, we have used the polyclonal antiserum raised to the $E$. coli UmuD and UmuD' proteins to probe whole-cell extracts from thirteen different strains of enterobacteria. Eleven strains expressed cross-reacting material only after treatment with the DNA damaging agent mitomycin C. It appears, therefore, that these species do possess a umuDC-like operons. Furthermore, they are regulated by mechanisms similar to the $E$. coli umuDC operon.

In $E$ coli, activation of the UmuD mutagenesis protein to UmuD' via RecAmediated proteolysis is a critical step in the mutation fixation pathway. The poor mutability of some strains, such as Klebsiella aerogenes and Citrobacter intermedius, correlates with an absence of UmuD post-translational processing. In others, such as S. typhimurium and Shigella boydii, induced UmuD was processed to UmuD'. In fact, the $S$. typhimurium UmuD protein appeared to be cleaved more efficiently than the $E$. coli UmuD protein under similar conditions. The data suggest that in these strains, conversion of UmuD to the mutagenically active UmuD' is not the rate limiting factor accounting for the weakly mutable phenotype. 
Cellular Response to Environmental DNA Damage

Specificity of In Vitro DNA Synthesis Error by a Single AminoAcid Replaced Rat DNA Polymerase $\beta$

Eumio Yatagai ${ }^{1}$, Magdy Mahmoud Mohamed", Akio Matsukage ${ }^{2}$, Takayasu Date $^{3}$, Fumio Hanaoka ${ }^{1}$, (1 Cellular Physiology Lab., RIKEN, ${ }^{2}$ Biology Div., Aichi Cancer Center Res. Inst., ${ }^{3}$ Dept. Biochemistry, Kanazawa Med. Univ. JAPAN)

To obiain some insights into the mechanisms of DNA replication error in mammalian cells, we started to study the influence of replacement of a single amino-acid in rat DNA pol. $\beta$ on the specificity of in vitro DNA synthesis error. Arg183, recognized as an important residue for primer recognition, was replaced by Gln (RQ183) and similarly neighboring Arg182 by Gln (RQ182) ${ }^{1)}$. M13mp2 single-stranded DNA was used as a template for in vitro DNA synthesis by wild-type and the above two mutant pol. $\beta$. The replicated molecule (RF) was introduced into the competent cells of E. coli S90C (muts ${ }^{+}$) or BMH71-18 (muts $S^{-}$) and the lac $Z_{\alpha}^{-}$mutant phage was selected as colorless or faint blue plaque on lawn of CSH50 (recA). The lac $Z_{\alpha}^{-}$mutation frequency obtained by wild-type pol. $\beta$ was increased from $1.7 \times 10^{-3}$ in mut $S^{+}$host to $8.2 \times 10^{-3}$ in mut $S^{-}$ host. This enhancement demonstrates that more than $80 \%$ of errors produced in this in vitro DNA synthesis can be corrected by mismatch repair systems. Surprisingly, these error rates in both genetic backgrounds were preserved for RF molecules copied by the mutant polymerases. However, the characteristic change in the error spectrum was observed following the transfection of mut $S^{+}$strain with RF molecules copied by the mutant pol. $\beta$. The frameshift error, addition of $C$ base in the run of $5 C$ (position 132 to 136) and $3 C$ (166 to 168), was observed in both cases of RQ182 and RQ183 at relatively high frequency, 3/41 and $7 / 46$, respectively, but none of them was detected in the copy by wildtype pol. $\beta(0 / 56)$. In contrast, $G$ to $T$ transversion was recovered in positions 82 and 149 by wild-type pol. $\beta$ at high frequency (7/56) but only a single recovery was observed with only RQ183 . We are now under investigation whether these kinds of changes in error specificity are unique to these single amino-acid replacements or likely to be occurred through more general effect, for example, reduced speed of DNA replication.

1) T. Date et al., (1990) Biochemistry 29, 5027-5034. 


\section{PROPERTIES OF THE RECOMBINANT XPAC PROTEIN}

Hiroshi ASAHINA, Naoyuki MIURA, Iwai MIYAMOTO, Ichiro SATOKATA, Kiyoji TANAKA

Institute for Molecular and Cellular Biology, Osaka University, 1-3 Yamada-oka, Suita, Osaka, 565, Japan

We have cloned the XPAC (Xeroderma Pigmentosum group A Complementing) gene (Taraka.K., et al., 1990, Nature 348:73-76). It encodes a prr tein of 273 amino acids with a zinc-finger motif. The XPACCDNA was placed in a Escherichia coli expression vector for the synthesis of a xpac protein. The recombinant xpac protein was expressed under the control of 17 promoter and contained 11 residues inherited from the expression vector construction in addition to 273 residues of the XPAC gene product. Its molecular weight is about 39-kDa in SDS-PAGE.

Microinjection of this protein restored unscheduled DNA synthesis (UDS) to the normal level in XP group A cells but not in cells from other complementation groups after UV irradation and treatment with 4-nitroquinoline 1-oxide (4NQO). This protein accumulated in the nucleus rapidly following injection into the cytoplasm. It suggests that the XPAC gene product contains the nuclear localization signal (NLS). Using a gel retardation assay, it was found that this protein had a DNA-binding activity.

We also investigate the role of a zinc-finger motif in the xpac protein on its DNA-binding activety. 
Cellular Responses to Environmental DNA damage

\section{THE CONSTRUCTION OF AN XRCCI CDNA MINIGENE, ITS FUNCTIONALITY IN EM9 CHO CELLS, AND THE PRODUCTION OF XRCCI FUSION PROTEIN IN E. COLI. Keith W. Caldecott, Kerty W. Brookman, and Larry H. Thomyson, Biomedical Sciences Division, Lawrence Livermore National Laboratory, Livermore CA 94550}

The CHO cell line EM9 was isolated from a mutagenized population of AA8 cells on the basis or sensitivity to EMS (1). EM9 is cross-sensitive to $\gamma$-rays, hydrogen peroxide and camptothecin (1-3). This cell line exhibits several interesting biochemical defects, including a reduced ability to rejoin DNA single strand breaks and a reduced frequency of homologous recombination in a plasmid transfection assay $(1,4)$. The primary phenotype of EMO cells is a 10-fold increase in the occurrence of sister-chromatid exchanges (SCEs) in the presence of bromodeoxyuridine (5). A human gene that corrects the EM9 defect and that lies on chromosome 19q13.2 has been identified and cloned as a cosmid. This gene is denoted XRCCl and is the first gene involved in the repair of DNA strand breaks to be isolated. XRCCl is $33 \mathrm{~kb}$ and encodes a $2.2 \mathrm{~kb}$ polyadenylated mRNA. A human cDNA clone has been isolated which encodes all of this message except the 5 t terminal 100 bp. This $\mathrm{cDNA}$ confers $-80 \%$ correction to EM9 cells as determined by the level of SCE (6) and enables EM9 cells to grow in chlorodeoxyuridine, albeit with a doubling time 8-fold greaver than AA8 cells. In order to attain full correction, with the ultimate aim of isolating the XRCC1 protein, we designed an oligonucleotide that provides the missing CDNA sequence. A complete human XRCC1 CDNA has now been constructed, and the sequence spanning the oligonucleotide insert has been verified. Results concerning the ability of the minigene construct to correct EM9 cells will be discussed as well as the results of our attempts to generate and purify MalE fusion protein from $E$. coli, which will be used as antigen for antibody production.

"Zoo" blots suggest that both Saccharomyces cerevisiae and $E$. coll may possess homologs of XRCC1. Hybridization of XRCCI CDNA to EcoRI digested genomic DNAs from these two organisms highlighted single bands under stringent wash conditions $(0.1 x$ SSC, $65^{\circ}$ C). Collaborative experiments are underway with Dr. Mike Crissman to isolate the yeast homolog. Work done under the auspices of the U.S. Dept. of Energy by LLNL under contract No. W-7405-ENG-48)

1. Thompson, L.H., Brookman, K.W. Dillehay, LE., Carrano, A.V., Mazrimas, J.A., Mooney, C.L. and Minkler, JL. A CHO cell strain having hypersensitivity to mutagens, a defect in DNA strandbreak repair and an extraordinary baseline of sister-chromatid exchange. Mutat Res. 95: 427-440, 1982.

2. P.A. Jeggo, unpublished observations.

3. Caldecott, K.W., and Jeggo, P.A. Cross sensitivity of Yray-sensitive hamster mutants to crosslinking agents. Mutat. Res. In press, 1991.

4. Hoy, C.A., Fuscoe. J.C. and Thompson, L.H. Recombination and ligation of transfected DNA in CHO mutant EM9, which has high levels of sister chromatid exchange. Mol. Cell. Biol. 7: 2007$2011,1987$.

5. Pinkel, D., Thompson, L.H., Gray, J.W., and Vanderiaan, M. Measurement of sister chromatid exchanges at very low bromodeoxyuridine substitution levels using a monoclocal antibody in Chinese hamster ovary cells. Cancer Res. 45: 5795-5798, 1985.

6. Thompson, L.H., Brookman, K.W., Jones, NJ., Allen, S.A., and Carrano, A.V. Molecular cloning of a human gene, XRCCI, involved in strand break repair and sister chromatid exchange. Mol. Cell. Biol. 10: 6160-6171, 1990. 
Celiniar Reaponses to Environnental Din Dange

Expression of Jxelelon Ropalr cones in Malignant and Mon-Malignant Fissues Iron cancer Patienta. Keenakshi Dabholkar'. Freida Bostick-Bruton', Charles Eguagu2, and Eddie Reed'. Medicine Branch, National Cancer Institute, Bethesda, Maryland 20892, '2aboratory of Immunology. National Eye Institute, Bethesda, Maryland 20892.

The patterns of expression of three human DNA repair genes (ERCC1, ERCC2, ERCC6) were assessed in 52 bone marrow specimens obtained from cancer patients in preparation for autologous bone marrow transplantation. Marrow was collected prior to the initiation of treatment in patients with sarcoma or testicular cancer: marrow was collected after initial cytoreductive therapy for patients with non-Hodgkin's lymphoma, Hodgkin's disease, and other tumors. Relative expression values of ERCC1, ERCC2, and ERCC6 ranged more than 300 fold. RNA from bone marrows from all disease groups showed a bimodal distribution pattern in the level of expression of the three genes: expression levels were either low or high, and intermediate levels of expression were noticably absent. Expression of the three genes (previously reported to map to Chromosome 19 (ERCC1, ERCC2) and chromosome 10 (ERCC6)) appears to be coordinated within an individual. When relative expression levels of ERCC1 were low, so were relative levels of expression of ERCC2 and ERCC6. Samples with high levels of expression of ERCC1 also exhibited high levels of expression of the ERCC2 and ERCC6 genes. This pattern was seen in all patient groups and thus appears to be independent of whether or not patients had received prior chemotherapy. Southern blot analyses of Pst I digests of DNA from 6 randomly selected bone marrow samples ( 3 high expressors of ERCCl and 3 low expressors), Indicate the absence of ERCCI gene amplification in high expressors, as evidenced by comparable hybridization signal intensities. Pst I digests of these DNAs did not exhibit restriction fragment length polymorphism suggesting the absence of major deletions or rearrangements in this gene in spite of the large range of levels of expression. The coordinated expression pattern seen in normal bone marrow was not seen in RNA obtained from fresh tumor tissues of 15 patients with ovarian or testicular cancer. ERCCI expression was higher in tumor tissue RNA from patients who were clinically resistant to platinum-based chemotherapy as compared to tumor tissues from patients showing a partial or complete response to therapy. FRCC2 levels were similar in RNA from tumor tissues from responders and non-responders. We conclude that expression of these ERCC genes, especially ERCC1, may be important markers for clinically relevant DNA repair capability, and that within an individual, their expression may be linked by a common regulatory mechanism. 
Uracil-DNA glycosylase : Overexpression and Purification. Pallavi R.Devchand and Johan van de Sande, University of Calgary, 3330 Hospital Drive N.W. , Alberta : T2N 4N1. CANADA.

DNA glycosylase enzymes recognise and excise specific damaged or unusual bases from DNA thus initiating the excision repair pathway. The most abundant of these enzymes is uracil-DNA glycosylase (UNG) which catalyses the excision of uracil bases from DNA. Uracil in DNA is the consequence of either the direct misincorporation of dUMP instead of CTMP during replication, or the deamination of cytosine to form uracil. The UNG enzyme is ubiquitous in nature and has been well characterised from a variety of organisms. The first ung gene to be sequenced was from $E$ coli (Varshney,U., Hutcheon,T and van de Sande, J.H. , 1988). This gene encodes a 229 amino acid protein with apparent molecular weight of 25,6 kD. The UNG enzyme does not require a cofactor and is fully functional in EDTA.

Although many DNA glycosylases have been purified and characterised, their conformational structures and reaction mechanisms remain to be solved. We have decided to use UNG as a model system for these glycosylases, and to elucidate the mechanisms by which it locates, recognises and cleaves its substrate from the DNA. In order to facilitate structural studies on the enzyme, the T7 RNA polymerase/promoter system is used to produce a large quantity of UNG (Tabor and Richardson, 1985). This involves the transformation of two plasmids into a DTLIII (rec A) E coli K12 strain : one plasmid contains the T7 RNA polymerase gene under an inducible promoter; and the second plasmid contains the ung gene under a T7 promoter. Transcription of the 77 polymerase gene is induced, resulting in the production of T7 RNA polymerase protein. This polymerase will then selectively transcribe the ung gene to produce large quantities of the UNG protein. The bacteria . are then harvested and lysed. The UNG enzyme is then purified to homogeneity. The overexpression and subsequent purification of the uracil-DNA glycosylase enzyme will Je presented. 
Cellular Responses to Envirómental DNA Damage

Isolation and Characterization of the DNA Repair gene REV2 of Saccharomyces cerevisiae. Robert E. Johnson, Michael Bankmann and Louise Prakash. Deparment of Biophysics, University of Rochester School of Medicine, Rochester, NY 14642.

The REV2 gene of Saccharomyces cerevisiae is required for DNA repair and effects UV induced reversion of certain ochre alleles. The gene has been cloned in our laboratory by complementation of the rev2-1 point mutation and the entire REV2 gene has been sequenced. The REV2 open reading frame is 3,507 nucleotides and predicts a protein of 1,169 amino acids with a calculated molecular weight of $134 \mathrm{kD}$. We have located three structural motifs in the REV2 protein that have been previously characterized in other proteins. First, there is a nucleotide binding site, including the seven domains that have been identified in the superfamilies of DNA and RNA helicases. REV2 also contains a novel zinc finger domain that has been classified as a cysteine-rich motif. This motif has been identified in only eight other proteins. Finally, there is a region of basic arvino acids followed by a potential leucine zipper in REV2 that resembles the DNA binding domains of several other leucine zipper containing proteins. Comparisons of REV2 to proteins found in the Genbank, EMBL and NBRF databases revealed no significant homologies.

Deletion mutarts of rev2 have been generated using the gene replacement method and have been examined for their effects on viability, DNA ref air, UV induced mutagenesis and sporulation. The rev2 deletion mutation does not effect sporulation or viability, and UV sensitivity and UV induced mutagenesis resemble that of the point mutant. A series of double deletion mutants were generated to determine the epistatic relationship of REV2 with other DNA repair genes. While REV2 belongs to the RAD6 epistasis group, there appear to be two pathways within this group since REV2 shows additivity with REV1 and REV3. We believe that $R E V 2$ is involved in error free repair and only plays a minor role in mutagenic repair.

Antibodies against the REV2 protein have been obtained by using a Rho:REV2 fusion protein as antigen in rabbits. These antibodies have been used to detect the REV2 protein on Western blots and also to immunoprecipitate REV2. Overproduction of the REV2 protein using the yeast CUP1 promoter has produced sufficient quantities of the protein for purification. Western analysis using REV2 antibodies will be used to follow the REV2 protein during purification. 


\section{Cellular Responses to Environmental DNA Damage}

- Towards A Model System for Mammalian Excision Repair: Genomic Structure and - Developmental Expression of the Murine ERCC-1 Gene, Jean J. Latimer and Roger A. Pedersen, Laboratory of Radiobiology and Environmental Health, University of California, San Francisco, CA 94143

ERCC-1 is one of several genes involved in the complex process of mammalian DNA excision repair. The ERCC-1 gene product has significant amino acid bomology with the yeast repair protein RAD10 and E. coli uvrA and uvrC proteins. Although it is known that ERCC-1 is involved in UV repair, it does not complement the kown defects in the UV DNA repair disease xeroderma pigmentosum. Therefore to determine the role of the murine ERCC-1 gene, we are attempting to create a mouse mutant for the ERCC-1 protein by gene targeting. For successful targeting it is necessary to know the genomic structure in some detail and the pattem of expression of the gene in the early embryo.

Southern analyses indicate that the murine gene, like its human homologue, appears to be present as a single copy in the genome. The mouse ERCC-1 gene, like its human counterpart, is composed of ten exons spanning an area of approximately $17 \mathrm{~kb}$. Restriction endonuclease and DNA sequence analyses oi the areas encompassing nine of the ten exons of EROC-1 indicate that the locations and organization of these exons are similar to those of the human gene. The CDNA sequences of the human and mouse ERCC. 1 genes have previously been shown to be $85 \%$ identical at the amino acid level. We are currently constructing targeting vectors designed to ablate expression of the ERCC-1 gene using the structural information

In order to determine the pattern of expression of ERCC-1 during development, we have analyzed the expression of ERCC 1 in the mouse embryo and in D3 embryonic stem (ES) cells. During post-implantation stages (12.5 days), the extraembryonic mesoderm and trophectoderm lineages show significantly higher steady state levels of ERCC-1 mRNA than embryonic lineages. Differential expression of this low level constitutive gene also occurs at other stages of development which may suggest that this zene has additional roles other than that which pertains to DNA repair. In contrast, ES cell lines which are derived from the inner cell mass (ICM) of the blastocyst, exhibit consistently low steady state levels of ERCC-1 mRNA. ES cells grown as aggregates in culture can differentiate spontaneously in vitro, modeling early differentiation events in vivo. We have also found that these cell aggregates express low levels of ERCC-1 mRNA regardless of their state of differentiation.

The existence of mutant CHO cell lines has demonstrated that the lack of expression of ERCC-1 is not nocessarily lethal at the cellular level. However, since ERCC-1 is expressed in the early embryo and in ICM derived ES cells, its absence in a embryo may be developmentally deleterious, which could account for the absence of a human disease associated with this gene. The creation of homozygous ERCC-1 mutant mice will allow us to address this question directly. (Supported by the U.S.D.O.E/O.HE.R. Contract No. DE-AC03-76-SF01012.) 
Cellular Responses to Environmental DNA Damage

Expression cloning of a Human DNA Repair Gene: Xeroderna Plgmentosum Complementation Group C. Randy J. Iegerski and Carolyn A. Peterson, Department of Molecular Genetics, The University of Texas M.D. Anderson Cancer Center, Houston, Texas 77030.

We have developed a CDNA expression vector based on the use of an Epstein-Barr virus (EBV) autonomously replicating plasmid for transformation of human cells. This vector, designated pEBS7, has a number of desirable properties including highly efficient transformation of human cultured fibroblast cell iines, rapid rescue of the episome from transformed cells and a simple and efficient method for the preparation of CDNA libraries. We have screened a large scale library prepared in pEBS7 for complementation of the repair defect in xeroderma pigmentosum group C cells. Double selection with hygromycin B (selectable marker present in piBS7) and UV resulted in the isolation of a cell line with normal resistance to $U V$ and normal levels of unscheduled DNA synthesis (UDS). Rescue of EBV episomes from this cell line resulted in the identification of a CDNA Clone that upon reintroduction into various XP-C cell Iines was able to fully complement the repalr defect as determined by colony survival assay and UDS. Sequencing of the DNA repair complementing CDNA insert is underway. 


\section{Cellular Responses to Environmental DNA Damage}

Characterization of XP-A Cells that Display Enhanced DNA Repair Capacities.

B. Stephen Lloud, Michael McCarthy and Temi Bellew, Center in Molecular Toxdcology, Dept. of Blochem., Vanderbilt Univ., Nashuille, TN 37232-0146; Raghbir S. Athwal and Gursurinder P. Kaur, Dept. of Microbiol. and Molec. Genetics, New Jersey Medical School, -Newark, NJ 07103-2757; Veronica M. Maher, Chia-Miau Mah and J. Justin McCormick, Dept. of Microbiol. and Biochem., Michigan State Univ., East Lansing, Ml 48824; Miroslava Protic, Lab. of Develop. and Molec. Immunity, NICHD, Bethesda, MD 20892; Augustinus Rinaldy, Dept. of Med., Univ. of Tennessee, Memphis, TN 38163; Toshio Mori, Nara Med. Univ., Kashihara, Nara 634, Japan, and Osamu Nikaido, Div. of Radiat. Biol., Kanazawa Univ., Kanazawa 920, Japan.

Previously we identfied a portion of the human genome (designated cosmid 2) which when transferred into XP-A ceils yielded cells with enhanced resistance to the cytotoxic effects of UV irradiation (Rinaldy et al., 1990, Proc. Natl. Acad. Sci. USA 87, 6818-6822). We have continued these studies and found that our gene is distinct from that reported by Tanaka and that our partially corrected XP-A cells are able to remove a varlety of bulky lesions but are very poor in the removal of (6-4) photoproducts relative to wild type cells. Specifically:

- It was of significant interest to determine whether cosmid 2, when inserted into GM4312 cells, would be able to enhance the resistance to the cytotoxic effects of ant BPDE and N-AcO-AAF. The results of these experiments showed that there was a very substantial enhancement in the survival of two of our previously characterized clones (2-0-A2 and 2-0-A4) relative to GM4312. The kinetics of removal of N-ACO-AAF adducts (C8-AF-G) ware measured and as expected, no lesions were removed from GM4312 while $-50 \%$ of the adducts were repaired by 2-0-A4 and normal cells at $18 \mathrm{hr}$. At longer repair times, normal cells continued to excise lesions while 2-0-A4 did not.

- The kinetics of (6-4) photoproduct and cyclobutane pyrimidine dimer removal were measured by an ELISA assay using monoclonal antbody 64M-2 and TDM-2, respectively. The rate of removal of the (6-4) photoproduct was extremely rapid in the wild type fibroblasts such that $92 \%$ of all $(6-4)$ lesions were removed at $3 \mathrm{hr}$ while for 2-0-A2 at $3 \mathrm{hr}$ there was no detectable removal of $(6-4)$ lesions, followed by a slow, but linear increase in the percent of lesions removed. The relative rates of (6-4) photoproduct removal in 2-0-A2 were $3 \%$ percent the rate of wild type cells, while the kinetics of dimer removal in 2-0-A2 proceeded at $-50 \%$ the rate of wild type. Thus there is a significant restoration of repair of the cyclobutane dimer without dramatically enhancing the rate of (6-4) photoproduct removal.

- Using CAT expression DNA repair assay we have tested for the restoration of transcription in 2-0-A2 versus the parental GM 4312 cells. Results show a 50-80\% increase in the relative CAT activity of UV-damaged cat vectors in UV-resistant transfectants as compared to GM4312. Since the CAT expression DNA repair assay is based on the reactivation of an actively transcribed gene, our results suggest that preferential repair present in normal human cells might not be exclusively induced in these UV-resistant transfectants by the repair-complementing gene.

- In order to map the new gene to a human chromosome oligonucleotide primers that are complementary to a segment of the repair gene were used to PCR amplify DNAs from a set of 20 different rodent/human hybrid cell lines representing all human chromosomes except chromosome 10. Amplifications occurred only in the hybrid CHH8 that contained normal human chromosome 8. Thus cosmid 2 represents a different gene that maps to human. chromosome 8. 
Analysis of the pronoter region of the human Os-mothylguanine-DKAwothyltranaferase gone. Philfo M. Potter, Linda C. Harr1s, Ke1zo Tano, Suzumu Shiota, Sankar Mitra and Thomas P. Brent. Depertment of Pharmacolog', St Juda Chlldren's Research Hospltal, Momph1s TN 38101 and Blology Division, Oak RIdge National Laboratories, Oak RIdge, TN 37813.

The repair of $0^{\circ}$-alkylgunine in mamalian cells is accomplished by an autoInactivating stolchlonetric reaction which results in the direct transfer of the alkyl group from DNA to a cystoine residue within the active protein, $0^{6}$. methylguanine-DMA-methyltransforase (MGMT). This enzyme is expressed in all normal human tissues al though some tumor derived cell ilnes apparentiy lack this repair activity. In order to understand the regulation of expression of the MGMT gene, the $5^{\circ}$ upatream controlling elements have been characterized. A $2.6 \mathrm{kbp}$ SatI genonic fragent was 1solated, 1157bp subjected to DNA sequencing and the first untranslated exon identified by homology with the GDMA. No obvious 'TATA' or ' CAAT' boxes are present within the sequence although two extensively GC rich areas (89x and 90x) separated by a polypyrimidine reglon are evident, consistent with pronoter sequences of other 'housekeeping' genes. Interestingly ten 'CCcCCC' notifs occur within these GC rich reglons although the relevance of these, at present, is not clear. Primer extension and SI nuclease protection assays Indicate that transcription is inltiated at position 955. In order to confirm these results, constructs containing various regions of the genomic clone and the bacterlal chloramphenlcol acetyltransferase reporter gene were transfected into mouve NIH3T3 cells. Acotyltransferase activity assayed 48 hours post transfection revealed maximal promoter activity in a 1.2kbp BamHI fragment. Minimal activity appears to be located to a 68bp segment immediately upstream of the transcription start site. Numerous consensus sequences for a variety of transcription activating factors are present within this genomic fragment and we are currently assessing thoir Importance in the control of expression of the MGMT gene. 


\section{Cloning and characterisation of a human AP endonuclease gene}

Craig N. Robson, Alison M. Milne and Ian D. Hickson

Imperial Cancer Research Fund Institute of Molecular Medicine John Radcliffe Hospital

Oxford OX3 9DU

United Kingdom

We have isolated cDNA clones encoding the major apurinic/apyrimidinic (AP) endonuclease from both bovine (BAP1) and human (HAP1) cells. The predicted sequences are highly conserved (greater than $90 \%$ identity) and show strong homology to the $E$. coli exonuclease III protein sequence. We have expressed the HAPI cDNA in $E$. coli, both to facilitate HAPl protein purification and to study genetic complementation of xth (exonuclease III) mutants. HAPI protein overexpressed using the $T 7$ polymerase system has been purified to homogeneity in milligram quantities and shown to be enzymatically active. A comparison of the activities of the recombinant protein with those of the HAPI protein purified from HeLa cells and the $E$. coli exonuclease III protein is in progress. HAPI protein expressed from the tac promoter in pKK223 was able to correct DNA repair and mutagenesis defects in E.coli xth mutants, and to rescue an dut $x$ th (ts) double mutant, which at $42^{\circ} \mathrm{C}$ accumulates lethal levels of unrepaired baseless sites. This complementation provides a starting point to analyse key residues in the HAP1 protein essential for AP endonuclease activity. 
Cellular Responses to Environmental DNA Damage.

Characterization of the structure and function of a hamster gene which partially corrects the excision repair defect of XPD cells. Andy Ryan and Janet E. Arrand, Cancer Research Campaign Gray Laboratory, P.O. Box 100, Mount Vernon Hospital, Northwood, Middlesex, U.K.

The existence of many complementation groups in the disease xeroderma pigmentosum may be indicative of various steps in the pathway of excision repair of UV damage in human cells. In an atempt to identify genes in this pathway, we have previously isolated a hamster genomic sequence which confers partial correction of the UV repair defect on XPD/HeLa hybrid cells. (Arrand et al. PNAS 86,6997-7001). The gene was isolated as an overlapping region on 2 cosmids; it was shown that this common sequence was sufficient to confer the partial correction.

The hamster DNA isolated in the cosmids contains more than one protein coding region. Part of the hamster thrombospondin gene has been found adjacent to repair gene sequences. The thrombospondin gene contains regions that are common to other globular proteins; this has caused background problems with northem and Southern analyses and has hampered the isolation of a full length repair gene CDNA. Further analysis of the cosmids has identified a region separate from the thrombospondin sequence that hybridises to human and hamster polyA+ mRNA species. We have sequenced and analysed this genomic region; it shows no significant homology to sequences entered in the EMBL database.

Recently, it has been shown that near complete correction of one XPD cell line and partial correction of our hybrid line is conferred by ERCC2 (C. Weber, personal communication). Our gene is not homologous to ERCC2 and hybridises to a different array of fragments in Southem blots. Further, it has been shown that restriction fragment polymorphisms detected with our hamster probe do not specifically cosegregate with the XPD phenotype (C. Mondello, personal communication). Our cloned gene may therefore be part of a different repair pathway which acts as a backup to the main UV repair pathway in mammalian cells. Such backup pathways have been identified in bacteria.

In order to determine the specificity of action of the cloned hamster gene it is being transfected by electroporation into all available immortalized XP cell lines and into the various rodent excision repair mutants. 
"Cellular Responses to Environmental DNA Damage"

Characterization of alkylating agent-sensitive mutants of mouse cells. Koki Sato*, Riyomi Eguchi-Kasai*, Takeko Odaka* and Tadahiro Shiomi**. Division of Radiation Hazards* and Genetics**, National Institute of Radiological Sciences, 4-9-1 Anagawa, Chiba 260, Japan.

Four mutants hypersensitive to the lethal effect of alkylating agents have been isolated from mouse leukemia I5178Y cells. Two of them have been selected for their sensitivity to methyl methanesulfonate (MMS) and the other two to ethyl methanesulfonate (EMS). They showed wide variations in their sensitivity to different alkylating agents and the order of viability after exposure was not necessarily the same among MMS, gMS and N-methyl-N'-nitroN-nitrosoguanidine (MNNG). The order changed again upon treatment with an alkylating and crosslinking agent, mitomycin $C$ (MMC).

One of the MS-sensitive mutants exhibiced crosssensitivity to $X$ rays. This mutant has reduced capacity in repairing DNA double-strand breaks (Eguchi-Rasai et al.: 1991).

An ultraviolet light (UV)-sensitive mutant had an increased sensitivity to an alkylating agent compared to wild-type cells. This mutant has been shown to be deficient in excision repair (Sato and Setlow, 1981). Sjnce mouse $I 5178 Y$ cells contain no detectable activity of 0 -methylguanine methyltransferase (R.B. Setlow, personal communication). other tolerant mechanisms may be operative in this mouse cell line.

The finding with an excision-repair-deficient mutant indicates involvement of an excision system in the repair of damage caused by an alkylating agent. 
Identification of $R A D 16$, a yeast excision repair gene homologous to transcriptional activator gene SNF2(SWI2) and recombinational repair gene RADS4. David Schild ${ }^{1}$, Brian J. Glassner ${ }^{2}$, Robert K. Mortimer 1,2, Marian Carlson ${ }^{3}$ and Brehon C. Laurent ${ }^{3}$. 1 Div. of Cell and Molec. Biol, Lawrence Berkeley Lab., Berkeley, CA 94720; 2 Graduate Group in Biophysics, and Dept. of Molec. and Cell Biol. Univ. of California, Berkeley, CA 94720; and 3 Dept. of Genetics and Development and Inst. of Cancer Research, Columbia Univ. College of Physicians and Surgeons, New York, NY 10032.

The RAD54 gene of Saccharomyces cerevisioe is involved in the recombinational repair of DNA damage and we have recently published the DNA sequence of this gene (1). The predicted amino acid sequence of the RAD54 protein shows significant homology with that of the yeast SNF2(SWI2) gene (2), a gene involved in the transcriptional activation of a number of yeast genes. In a 492 amino acid region, RAD 54 shares $31 \%$ identical and $40 \%$ conserved amino acids with SNF2, and this region of homology includes presumed nucleotide and $\mathbf{M g}^{++}$binding sites.

Both the RAD54 and SNF2 proteins also share homologies with a previously uncharacterized open reading frame (ORF), part of whose sequence was reported with the sequence of an adjacent, unrelated gene (LYS2) (3). To test whether this ORF is involved in transcriptional activation or DNA repair, yeast strains deleted for part of it have been isolated. These strains do not show a Snf-like phenotype, but they are UV sensitive, indicating a defect in DNA repair. This gene has been identified as the excision repair gene RAD16. Analysis of the rad16 deletion mutations indicate that RADI6 does not encode an essential function, and that this gene is not absolutely required for excision repair. Partial sequence of the RAD16 gene reveals that the homologies to RADS4 and SNF2 encompass only the terminal half of the region shared by RADS4 and SNF2. Outside this region of homology, the predicted RAD16 protein contains a cysteine-rich zinc fingerlike motif which has been found recently in eight other proteins (4), including the yeast RAD18 protein. The homologies between RAD16, RAD54 (genes in two different DNA repair pathways), and $S N F 2$ is also shared by several additional, recently isolated yeast genes.

RAD16 is a particularly interesting yeast DNA repair gene because it is one of only three yeast genes which appears to be involved primarily in repairing nontranscribed regions. The radl6-1 mutation has been shown by Terleth et al. (5) to cause a much stronger defect in the repair of pyrimidine dimers in a transcriptionally inactive region $(H M L \alpha)$, as compared to Mato, a transcribed region; this phenotype is shared by the rad 9 and rad2 4 mutations. The human xeroderma pigmentosum complementation group $C(X P-C)$ cells have likewise been shown by several laboratories to be defective in the repair of non-transcribed regions of the genome ( 6 and references therein). Since the XP-C gene has not yet been sequenced, it is notpossible to determine if it shares homologies with RADI6.

\section{References:}

1. Emery, H. S., Schild, D., Kellogg, D. E. \& Mortimer, R. K. (1991) Gene 104, 103-106.

2. Laurent, B. C., Treitel, M. A. \& Carlson, M. (1991) Proc. Natl. Acad. Sci. USA 88, 2687 2691.

3. Fleig, U. N., Pridmore, R. D. \& Philippsen, P. (1986) Gene 46, 237-245.

4. Freemont, P. S., Hanson, I. M. \& Trowsdale, J. (1991) Cell 64, 483-484.

5. Terleth, C., Schenk, P., Poot, R., Brouwer, J. \& Van De Putte, P. (1990) Mol. Cell. Biol. $10,4678-4684$.

6. Venema, J., Van Hoffen, A., Karcagi, V., Natarajan, A. T., Van Zeeland, A. A. \& Mullenders, L. H. F. (1991) Mol. Cell. Biol. 11, 4128-4134. 


\section{Cellular Responses to Environmental DNA Damage}

The Human Double-strand Break Repair Gene (XRCC5) Is On Chromosome 2 and Complements a peficiency in the Cho Mutant, XRs-6. Y.J. siciliano, M.S. Park, and D.J. Chen", Department of Molecular Cenetics, Qniversity of Texas M.D. Anderson Cancer Center, Houston, IX 77030, 'Iife Sciences Division, Ios Alamos National Iaboratory, Los Alamos, MN 87545.

Identification of human chromosomes carying DNA repair genes that complement deficiencies in rodent cell repair gene mutants has been done by somatic cell genetic techniques. The procedure Involves the fusion of human cells to the rodent mutant cells and hybrids selection at levels of DNA-damaging agent to which the mutant celle are hypersensitive. Concordance of hybrid clone resistance to the selecting agent with a particular human chromosome (or part of a human chromosome) identifies the location of the complementing gene - Excision Repair cross complementing (ERCC) or X-ray Repair cross Complementing (XRCC) . Such studies have mapped ERCC1, BRCC? and XRCC1 onto human chromosome 19913.1q13.3; HRCC3 and BRCC5 onto chromosomes 2 and 13 respectively; and XRCC4 onto chromosome 5. Further, similar preliminary data suggest the locations of BRCC4 on chromosome 16p13.13-p13.3, and XRCC2 and XRCC3 on chromosomes 7 and 14 respectively (reviewed in Thompson et al., 1990, in Genetic Mechanisms in Carcinogenesis and Tumor Progression, Wiley-Liss, Pp.83-95; and Thompson et al.. in press, In Ionizing Radiation Damage to DNA: Molecular Approaches).

In this report we use similar procedures to identify human chromosome 2 as carrying the gene that complements the deficiency of XRS-6 cel1s in repairing DSBs. 17 independent somatic cell hybrids were made between normal human fibroblasts and XRs-6 cells. Each hybrid was tested for $x$-ray resistance and screened for the presence or absence of 42 human isozyme and molecular markers representing every human chromosome arm. The marker for the p-arms of chromosomes 2 (YDHI) showed of discordance with the $x-r a y$ resistance phenotype. Three resistant hybrids were subcloned. An additional $13 x$-ray resistant and $8 x$-ray sensitive subclones were isolated and tested for markers. yinh once again showed of discordancy with the phenotype while markers for all other chromosome regions (Including the g-arm of chromosome 2 -- the location of BRCC3) were randomly present. we name the complementing gene XRCC5.

XRCC5 is therefore genetically distinct from other XRCC genes mapped thus far (they have been all located on different chromosomes) and is now the second repair gene assigned to human chromosome 2 . 
rellular Responses to Environmental DNA Damage

Damage-specific DNA-binding Nuclear Proteins in Human DNA-repair Deficiency Diseases. Sagarika Kanjilal and Milliam D. Taylor, Department of Moiscular and Cell Biology. The Pennsylvania State University, University Park, Pa.. 16802 .

A number of genetic disorders associated with malignancies, mutagenesis and chromosomal instability arise from defects in cellular systems responsible for the repair or tolerance of radiation induced DNA damage. Examples include the UV-sensitivity diseases Xeroderma Pigmentosum(XP), Cockayne's Syndrome(CS), and Bloon's Syndrome(BS). In addition, Fanconl's Anemia(FA) patients demonstrate marked sensitivity to DNA-DNA cross-1inking agents, and Ataxia Telangienctasia(AT) patients are unable to withstand exposure to lonizing radiations such as X-rays. Simultaneous occurrence of two DNA repair disorder diseases has been documented and there are now eight documented cases of CS patients who also belong to various XP complementation groups. Considering the rarity of these disorders, it has been proposed that CS may arise from mutations in the XP-related repair system. Based on the reasoning that a key function of the repair system must be to differentiate between native and damaged DNA, we applied gel-shift electrophoresis to detect damaged-DNA specific nuclear factors. Our results indicate that CS, XPA, BS, and AT may share a coumon biochemical defect as they show very similar changes from normal cells in the pattern of their damaged-DNA specific binding activities. 
Cellular Responses to Environmental DNA Damage

Characterization of the Herpes Simplex Virus Type 2 Uracil-DMA Glycosylase Gene Cluster

Diane H. Worrad and Sal Caradonna

UTDNJ-SOY

401 South Central Plaza

Stratford, NJ 08084

Previous studies from this laboratory have shown that herpes implex virus (HSV) encodes a uracil-DNA glycosylase. Seguence analysis indicates that the uracil-DNA glycosylase gene of HSV is flanked by two open reading frames of unknown Iunction. A characteristic of herpesviruses is that the virus tends to group genes of similar function together within its genome. With this in mind we have attempted to characterize the open reading frames adjacent to the uracil-DNA glycosylase gene in an effort to determine whether these encode associated repair functions. Data presented here characterize the UL3 open reading frame that is located downstream from the uracil-DNA glycosylase gene.

The UL3 region of HSV type 2 was subcloned, sequenced, and shown to encode a 218 amino acid protein with a predicted molecular weight of 28,000. Computer analysis of the protein revealed that it contained properties characteristic of many HSV glycoproteins. These properties include: 1) a hydrophobic N-terminus that codes for a signal peptide, 2) an amino-terminal domain with a site for N-glycosylation, 3) many sites for 0-glycosylation, 4) a hydrophobic transmembrane domain, and 5) a carboxy-terminal domain. In addition, the UL3 open reading frame also contains a nuclear localization signal.

A hydrophilic fragment was subcloned into an expression vector to create a fusion protein used for the generation of polyclonal antibodies in rabbits. Immunoprecipitation of in vitro translated $4 \mathrm{hr}$ postinfected (PI) HSV2 mRNA revealed a 34 kilodalton (kd) protein on a denaturing polyacrylamide gel. However, immunoprecipitation of in vivo [35S]-methionine pulse-labelled HSV2 protein extracts revealed multiple molecular weight forms ranging from 68-72 kd. By 10hr PI, the only molecular weight species immunoprecipitated was a $60 \mathrm{kd}$ protein. To determine where the protein was located during infection, an immunocytochemical analysis was performed using a Iluorescein conjugated secondary antibody. Results from these experiments revealed that, at $9 \mathrm{hr} \mathrm{PI}$, the UL3 protein appears as discrete particulates within the nucleus.

Current work is focused on determining whether this protein has DNA binding properties on native as well as damaged DNA substrates. 
Host Variation in Radiosensitivity among A-bomb Survivors, Sadayuli Ban, ${ }^{2}$ John B. Cologne, ${ }^{2}$ Dept of Genetics' and Statistics, Radiation Effects Research Foundation, Hiroshima 732, JAPAN.

A hypothesis has been raised that the population of A-bomb survivors may not include radiosensitive persons because they died when young of acute infections (the "selection" hypothesis).' If this hypothesis were correct, the surviving population would provide a biased underestimate of the true risk of radiogenic cancer. To test the hypothesis, we have measured the in vitro radiation sensitivities of fibroblast cells and peripheral blood cells. Fibroblasis were established from skin biopsies obtained from 56 individuals with or without exposure to A-bomb radiation. Data on the survival of fibroblasts following exposures to $\mathrm{X}$-rays or neutrons showed large individual differences in $D_{10}$ values. ${ }^{23}$ The $X$-ray sensitivity of blood cells has been evaluated with a micronucleus assay. Results of 937 AHS participants' lymphocytes also show a wide variation in radiosensitivity within the population. Taken together the two studies on different endpoints and different cell types do not provide support for the view that the A-bomb survivors include a disproportionately large number of either radioresistant or -sensitive persons. While it may never be possible to answer this question to everyone's satisfaction, our experimental approaches provide at least some tests of the hypothesis.

(References)

1. A.M. Stewart: Health Physics. 24, 223-240, 1973.

2. S. Ban, R.B. Setlow et al: Cancer Res. 50, 4050-4055, 1990.

3. S. Ban, R.B. Setlow et al: J. Radiat. Res. (Supple.) 32, 330338, 1991.

4. S. Ban, M.P. Donovan et al: J. Radiat. Res. 32, 13-22, 1991. 
Cellular response to eavirormental

DNA damage

TISSUE LEUELS DF AHIDATIUE DNA DAMAGE (B-HYDROHYOEOAYGUANOSINE) IN HUMAN INFLAMMATORY DISERSE

Saber Bashir. Nicola J. Simmonds. Paul G. Winvard. David S. Rampton. David R. Blake. Gilmour Harris. Inflammation Research: Group, London Hospital Medical College, London E1 2AD, UK.

Oxidative DNA damage may contribute to the aetiology of: Inflammatory autoimmune diseases such as rheumatold arthritis (RA) and systemic lupus erythematosus (SLE) as well as to cancer and ageing. A major specific product of oxidative damage to cellular DNA, is 8-hydroxydeoxyguanosine (8-OHdG) formed by the reaction of the hydroxyl radical ( $\mathrm{OH}$ ) at the $\mathrm{C8}$ position of deoxyguanosine in DNA. 8-OHdG can be measured with high sensitivity, at femtomole levels, by high performance liquid chromatography with electrochemical detection.

We have measured the levels of 8-0HdG in the DNA of Iymphocytes and polymorphonuclear leucocytes (PMN's), respectively, from the blood of patients with inflammatory autolmmune diseases, such as RA, SLE, vascullitis and sclerodarma, as well as healthy controls. DNA of blood lymphocytes showed significantly Increased levels of 8-OHdG in RA, SLE and vasculitis but no signiflcant difference from heaithy donors was found in the scleroderma Iymphocyte DNA. In contrast, PMN DNA showed no difference between these groups and also no correlation was found between levels of 8-OHdG in lymphocyte and PMN DNA in Individuals of all the groups tested.

The role of chronic inflammation in determining the level of 8 OHdG in cellular DNA is unknown. DNA from normal and abnormal areas of colon obtained surgically from patients with chronic Intlammatory bowel diseases, ulcerative colltis (UC) and Crohn's disease (CD), has been analysed. The level of 8-OHdG was ralsed in DNA from Inflamed areas of colon compared to non-involved areas in some cases of UC. In contrast, similar studies of CD showed no difference, or even lower levels in diseased areas as compared to unaffected areas. The role of infiltration by inflammatory cells in this respect has to be determined, as well as any other factors regulating the levels of $8-0 \mathrm{HdG}$ in the cellular DNA of target tissues. Repair proflclency is obviously a major process for study, since evidence for repair of 8-OHdG in cellular DNA has been reported (Tchou et al Proc Natl Acad Scl. USA 1991; 88: 4690). 


\section{Cellular Responses to Environmental DNA Damage}

Variability in Background Somatic Mutation in a Normal Human Population - Incidence of 'Outlier' Individuals with Stably Elevated Frequencies Increases with Age. William L. Bigbee', Martha M. Moore ${ }^{2}$, Irene P. Jones', Ronald H. Jensen'1, Richard G. Langlois', and Stephen G. Grant'1 ' ${ }^{1}$ Biomedical Sciences Division, Lawrence Livermore National Laboratory, Livermore, CA and 2Health Effects Research Laboratory, U.S. Environmental Protection Agency, Research Triangle Park, NC.

The glycophorin A (GPA) buman in vivo somatic mutation assay enumerates rare erythrocytes of GPA allele-loss variant phenotypes in peripheral blood samples. Two independent populations of variants are observed corresponding to conversion of cells heterozygous for the 2 GPA alleles to cells of hemizy gous and homozygous phenotypes. Hemizy gous variants may arise by point mutation, deletion/insertion, inactivation of one GPA allele, or chromosome loss. Homozygous variants, characterized by loss of one GPA allele and expression of the remaining allele at twice the heterozygous level, may arise by chromosome loss and duplication, gene conversion, or somatic recombination. Both classes of variant erythrocytes are observed in normal individuals with typical background frequencies of $\sim 10^{-6}-10^{-5}$. A study of a large number of individuals was undertaken to investigate the range of inter-individual variation present in a normal human population and to identify potential factors contributing to the observed variability. Assays were performed on blood samples from 377 individuals, ages 8 to 77 years, who are Lawrence Livermore National Laboratory employees, retirees, or family members. As observed previously with this and other in vivo somatic mutation assays, donor age and environmental exposures such as smoking contribute to the overall variation observed in both hemizygous and homozygous variant cell frequencies. These data also reveal 27 individuals with elevated frequencies of at least 4 fold and as great as $\sim 50$-fold over typically observed levels. The 'outlier' variant cell frequencies observed in these individuals are reproducible in blood samples obtained at intervals exceeding one red cell lifetime ( -120 days) indicating that these levels are a stable feature of erythropoiesis in these donors. Analysis of the incidence of these 'outlier' individuals with age shows a statistically significant increase with age from a level of $\sim 4 \%$ in young adults to $-30 \%$ in individuals over 60 years of age. Thus it appears these 'outlier' frequencies develop in an age-dependent fashion in some individuals within the normal population. Data from a longitudinal study of 2 normal donors sampled 26 and 31 times, respectively, over the last 3 years also support this observation. In one of these donors, a 32 year old female, with an unremarkable homozygous variant frequency of $\sim 5 \times 10^{-6}$, no change was observed over this period. In contrast the homozygous variant frequency in the second donor, a 44 year old female, initially observed to be slightly elevated at $\sim 12 \times 10^{-6}$ has gradually increased to $-20 \times 10^{-6}$ over this period. Finally, the HPRT lymphocyte cloning assay has been applied to a sub-set of these 'outlier' individuals. In an initial study of 8 of these donors, 2 displayed markedly elevated mutant frequencies of 54 and $78 \times 10^{-6}$, a level $\sim 10-$ fold higher than typical values. Thus the GPA assay appears to have identified some individuals with markedly elevated levels of somatic mutation evidenced at different loci in different cell types. This apparent heterogeneity of somatic mutation within a normal population has important implications for differential effects of aging and pre-disposition to disease.

(Work performed under the auspices of the US DOE Contract W-7405-ENG-48 with the : support of NIH Grant CA48518) 
Mutagenic Erfects of Advanced Glycosylation Endproducts (AGEs) in Eukaryotic Cells. Richard Bucala, Annette T. Lee, Linda Chiu, and Anthony Cerami. Laboratory of Medical Biochemistry, The Rockefeller University, 1230 York Avenue, New York, NY 10021.

Reducing sugars such as glucose react non-enzymatically with the free amino groups of proteins to form a group of protein-bound moieties with fluorescent and cross-linking properties. These compounds, called advanced glycosylation endproducts (AGEs), accumulate with age and have been implicated in the structural and functional alterations of proteins that occur during normal aging. Recent studies have shown that the primary amino groups of nucleotides also can serve as substrates for advanced glycosylation. In vitro, the incubation of either DNA or single nucleotides with glucose produces absorbance and fluorescence changes similar to those observed for AGE compouads bound to protein. Incubation of phage or plasmid DNA with glucose leads to an inactivation of phage function and to an increase in plasmid mutations. In bacteria, glucoseinduced mutations result in part from the mobilization and insertion of specific host transposable elements, such as IS-1 and $7 \delta .2,2$

We sought to investigate the possibility that the accumulation of DNA-AGE adducts in eukaryotic cells might contribute to age-related genotoxicity and oncogenesis. To approach this question, we studied mutagenesis in a DNA shuttle vector transfected into cultured murine tymphoid cells (X63Ag8.653). This shuttle vector contained the lacI mutagenesis marker, the gene for neomycin resistance, and prokaryotic and eukaryotic origins for DNA replication. Shuttle vector DNA was incubated for 1 hour at $37^{\circ}$ with an AGE-reactive intermediate (AGE-RI) prepared by incubating $1 \mathrm{M}$ glucose-6-phosphate with $10 \mathrm{mM}$ lysine (pH 8) at $37^{\circ}$ for 4 days. These conditions previously have been shown to induce DNA transposition in a bacterial, model system. ${ }^{2}$ Transfected cells were selected for growth in neomycin, cultured for 2-3 weeks, and episomal plasmid DNA then recovered for lact screening in E coli (MC1061 F 150 kan). After reaction of AGE-RI with shuttle vector DNA, the lacl mutagenesis rate increased logarithmically in a dosedependent fashion.

$\begin{array}{cccc}\text { AGE-RI (lysine equiv.) } & \text { cexperiments } & \text { Mutation Rate (Mean \%) } & \text { Range } \\ 0 \mathrm{mM} & 6 & 0.1 & 0.03-0.2 \\ 5 \mathrm{mM} & 5 & 5.2 & 0.15-14 \\ 6.5 \mathrm{mM} & 6 & 14.4 & 1.4-26 \\ 7.5 \mathrm{mM} & 6 & 28.0 & 4.0-68\end{array}$

Restriction digest analysis revealed that the majority of the AGE-induced mutations were the result of DNA insertions or deletions (> $90 \%$ ). Mutant clones were analyzed by Southern hybridization and DNA sequence analysis. The inserted DNA was found to be of murine genomic origin. The ability of advanced glycosylation products to induce such extensive DNA damage and rearrangements suggests that these reactions represent a potential source of age-related cellular mutations in vivo.

2.Bucala, R., Model, P., and Cerami, A. (1984). Proc Natl Acad Sci USA 81, 105-109.

${ }^{2}$ Lee, A T., and Cerami, A (1991). Mutation Research 249, 125-133. 
Cellular Responses to Environmental DNA Damage

CALORIC RESTRICTION DECREASES THE AGE-RELATED DECLINE IN BOTH DNA EXCISION REPAIR AND LOSS OF DNA POLYMERASE a FIDELITY. David I. Busbee, Vinod K. Srivastava, and Susan D. Miller. Faculty of Toxicology, Department of Anatomy and Public Health, College of Veterinary Medicine, Texas A\&M University, College Station, TX 77843.

DNA excision repair was examined in fibroblasts from young vs old human donors and in bepatocytes and fibroblasts from young vs old and ad libitum vs calorie restricted female C57BL/6N mice and F-344 rats. DNA polymerase $\alpha$ expressiōn and fidelity were examined in bepatocytes from young vs old ad libitum and calorie restricted female C57BL/6N mice. Excision repair was evaluated by ${ }^{3} \mathrm{H}$-thymidine incorporation, BrdUrd incorporation with detection using fluor-labeled monoclonal anti-BrdUrd and scanning laser cytometry, and alkali lability of DNA as determined by single cell gel electrophoresis with detection using scanning laser cytometry. Lung fibroblast cell lines were established from ad libitum and calorie restricted female F.344 rats ages 6 mo, $16 \mathrm{mo}$, and $26 \mathrm{mo}$. Both UV-and MMS-initiated excision repair declined as a function of increased age in fibroblasts from ad libitum rats. The age-related decline in excision repair seen in cells from ad libitum rats was not seen in cells from calorie restricted animals. Human fibroblasts from young vs old donors were examined for UV-and MMS-initiated DNA repair. Excision repair initiated nicks and gaps in the fibroblast DNA, proliferating cell nuclear antigen (PCNA) was elaborated in response to mutagen treatment, and repair-associated DNA synthesis was detected as ${ }^{3} \mathrm{H}$-thymidine incorporation; however, while DNA excision repair was completed in cells from young donors restoring the genomic integrity, it was not completed in cells from old human donors, resulting in fragmentation of the genome. An age-related change in expressed hepatic DNA polymerase isozymes and a decline in DNA polymerase a total activity, specific activity, and fidelity of synthesis was noted for ad libitum C57BL/6 mice. Specific polymerase isozymes which were age affected in ad libitum animals were significantly less affected in calorie restricted animals. Treatment of some, but not all, of the pol isozymes with inositol-1,4-bisphosphate increased the enzyme total and specific activity and the fidelity of synthesis. These data support the hypothesis that DNA repair declines as a function of increased age, and that the repair decline can be slowed by caloric restriction. Supported in part by grants AG06347, AG07739, and a COVM research enhancement award. 


\section{"Cellular Reoponses to Indronmental DNA Damage"}

Acetylntor Phenotype Influences Colonic Prollerntion in Uninvolved Mncoan in Pattents with Colorectni rieoplanil Bose N Butler. Wendy J Butler. Wheong $K$ Khoo and lan C Roberts-Thomson. Department of Gastroenterology. The Queen Elizabeth Hospital. Woodville SA 5011. Australla

The cause of colorectal cancer remains unclear in most patients although epidemiological studies have found assoclations with high dietary intakes of fat. meat and calories. Two studies from other centres have raised the possibility that fast acetylators have a higher than expected rals for the development of colorectal cancer. This has been corroborated by our own study ahowing that the frequency of fast acetylators in pattents with colon cancer (51\%) was algnificantly higher $(p<0.05)$ than that in appropriate control subjects $(34 \%)$. One posstble mechanism for this association may involve the activation of arylamines found in meat to intermediates which initiate or promote carcinogenesis. The atm of the present study was to compare proliferative activity in uninvolved mucosa from patients with colorectal neoplasta who were identibed as being fast or slow acetylators. Acetylator status was determined by the relative concentrations of acetylated and non-acetylated sulfamethaxine in blood (HPLC). one and four hours after oral administration $(20 \mathrm{mg} / \mathrm{kg})$. Colonic blopsies were obtained from uninvolved mucosa in patients with adenoma or adenocarcinoma undergoing colonoscopy or surgery. Proliferattve activity was assessed by flow cytometry and the results were expressed as the percentage of cells in phases S+G2M. The mean $( \pm S E)$ proliferative activity in uninvolved mucosa from patients with neoplasia was significantly higher $(p<0.02)$ in fast acetylators $(9.25 \pm 1.0 \%, n=23)$ when compared to slow acetylators $(6.5 \pm 0.5$ $\% . n=27)$. The enhanced proliferative activity seen in fast acetylators raises the posslbility of links between fast-acetylation. enhanced proliferation and susceptibility to colonic neoplasta. This could be mediated by higher concentrations of acetylated carcinogens. 
CHARACTERIZATION OF A N-METHYL-N-NITRO-N-NITROSOGUANIDINE TRANSFORMED CEU LINE DERIVED FROM SYRIAN HAMSTER TRACHEA Ming J.W. Chang and Ching C. Tsai, Toxicology/Pharmacology Lab, Chang Gung Medical College, Tao-Yuan, Taiwan, ROC

In order to understand the molecular mechanism of pulmonary carcinogenesis, an in vitro transformation was done on a tracheal cell strain which was derived from a young female Syrian hamster. The cells were cultured in F-12 medium supplemented with $10 \%$ FBS, $20 \mathrm{ng} / \mathrm{mL}$ EGF, $10 \mu \mathrm{g} / \mathrm{mL}$ insuline, $1.8 \mu \mathrm{g} / \mathrm{mL}$ hydrocortisone, $100 \mathrm{U} / \mathrm{mL}$ penicillin, $100 \mu \mathrm{g} / \mathrm{mL}$ streptomycin, and $2.5 \mu \mathrm{g} / \mathrm{mL}$ amphotericin B and subcultured (1 to 3) every 4 days. The trancformation was done by the technique of focal transformation assay involving one dose of $25 \mu M$ MNNG on the plated cells $\left(2 \times 10^{4} / \mathrm{cm}^{2}\right)$. After stimulation of proliferation by one subculturing, the morphologically transformed foci were piled up on the normal looking monolayer cultures. Three cell lines were derived from these foci. They were tested for ability to form colonies in soft agar. All three showed positive response. One of them, designated as HT-MNNG-1b, was studied for its growth characteristics, in vivo tumorigenicity, and response to sodium butyrate. Our results showed that (1) its growth in culture dish was no longer contact-inhibited, (2) it grew faster during further subculture not only in dish but also in soft

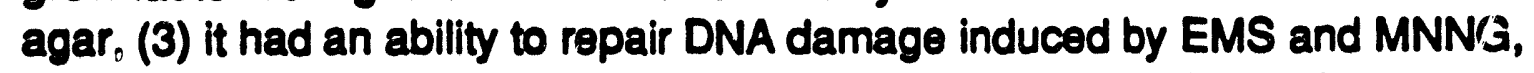
but the repair capacity decayed after many subculturings, (4) its colony formation efficiency increased from $41 \pm 6 \%$ to $77 \pm 4 \%$ in about ten subculturings, (5) its karyotyping indicated an instability of the genome as less cells possessed a chromosomal number of 44 after multiple subculturings, (6) it produced a malignant fibrosarcoma three and half months after an injection of $4.2 \times 10^{6}$ cells into the cheek pouch of a syngenetic woanling hamster, and (7) its growth was significantly suppressed by sodium butyrate at $80 \mu \mathrm{g} / \mathrm{mL}$. Currently, the interaction of the cells with sodium butyrate is being characterized.

(Supported in part by a research grant of Chang Gung Medical College, CMRP 279 and by grant NSC-80-0412-B182-63.) 


\section{Cellular Responses to Environmental DNA Damage}

Prognosis factors in myelodysplasic syndromes (MDS) : a biological and cytogenetical study in a cohort of 33 patients.

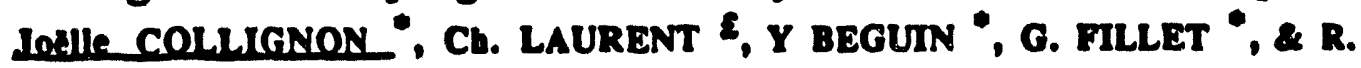
PARIDAENS \&. " Dept. of Haematology : Dept. of Oncology and Radiotherapy University of Litge - CHU $\$ 000$ Sart Tilman - Belgium.

33 cases of MDS have been diagnosed between 1985 and 1990. For each of them, bone marrow smears and bone marrow cytogenetics have been analyzed. Followup study concerns only 29 patients because for 4 were no more available.

Subtypes of MDS were classified according to FAB classification : data are as follow : 9 - refractory anemia (RA ); 4 - RA with ring sideroblasts (RARS); 7 - RA with excess of blasts (RAEB); 8 - RAEB in transformation (RAEBt); and 5 - chronic myelomonocytic leukemia (CMMI).

Among these 33 patients, 4 presented secondary MDS: 2 have been previously treated by radiotherapy and 2 by radio- and chemotherapy.

Survival curves have been calculated for the group, considered as a whole; and ; for each sub-group. The median survival for the groups has been estimated to be: 712 days for the group; RA - 662; RAEB - 712; RAEBt - 225; CMML - 840. ; All patients classified in the RARS subgroup were still alive at time of the study.

From our results, it appears that bone marrow fibrosis was associated with MDS in 12 patients $( \pm 30 \%$ ). This fibrosis has been found essentially associated with RAEB \& CMML subtypes; respectively 5 in RAEB, 5 in CMML; 1 in RA \& 1 in RARS.

Overall incidences of chromosomal aberrations was $66 \%$ with complex caryotypes, trisomy 8, monosomy 7, loss of Y chromosome, del 20q, del 5q, del 11q, del $13 \mathrm{q}$, del 7q, the latter being the less frequently found. Although no specific chromosomal aberrations have been related with subtypes of MDS, the lowest frequency of abnormalities was observed in the RA subtype. Our results will be discussed with : respect of the literature 


\section{Cellular Responses to Environmental DNA Damage}

A TRANSGENIC MODEL TO TEST THE ROLE OF DNA REPAIR IN PREVENTION OF NITROSOUREA INDUCED T- CELL LEUKEMIA/LYMPHOMA. LL Dumenco, E All ay, JC Mol fman, K Norton and SL Gerson. Ireland Cancer Center, University Hospital of Cleveland and - Case Western Reserve University, Cleveland $\mathrm{OH}$

Nitrosoureas induce secondary lymphomas in mice and leukemias in humans by causing DNA damage which, if unrepaired, may lead to mutational activation of one or more oncogenes. These mutational events may occur at high levels in hematopoietic cells due to an inability to repair specific sites of nitrosourea-induced DNA damage. The highly mutagenic DNA adduct, $0^{6}$ al kylguanine, is formed by nitrosoureas and is repaired by the enzyme, $0^{6}$ alkylguanine-DNA aikyltransferase (06AT). In previous studies, we found low levels of this enzyme in human and murine hematopoietic and lymphoid cells and hypothesized that these cells were targets for persistent DNA damage. He used our mouse model of secondary lympmoma/leukemia to test the role of 06AT in protection from carcinogenesis. In this model, 67\% of C57Bi/6xSJL FI mice develop a Tcell 1ymphoma/leukemia within $7 \mathrm{mo}$ of receiving $50 \mathrm{mg} / \mathrm{kg}$ methylnitrosourea (MNU) ip. Therefore, we developed a transgenic mouse line expressing high levels of 06AT targeted to $T$ lymphocytes. A chimeric gene was constructed consisting of the 702 bp entire coding region of the human 06AT gene (MGMT) [isolated from human VACO6 cells by PCR cloning], linked to the 340 bp avian Bact in promoter, the 710 bp bovine growth hormone poly $A$ sequences, and the 2 $\mathrm{kb} 3^{\prime}$ locus control region from the human $\mathrm{CD2}$ gene, which directs expression of linked heterologous genes to $T$ lymphocytes. Of 23 mice born after microinjection, three founders contained the entire chimeric gene of which two (Fo11 \& Fo22) transmitted to Fl offspring in a Mendelian fashion, and one (F09) as a mosaic. Approximate gene copies per founder were: Fo9: 5, Foll: 10, F021: 150 and consisted primarily of head to tail concatimers. A consistent pattern of tissue-specific MGMT mRNA and 06AT protein expression was found in the Fl offspring of Foll, with thymic expression $>$ muscle $>$ bone marrow > spleen > brain and no detectable expression in liver or kidney. 06AT levels in thymus were 2340-13900 fmol/mg protein or 54-125 fmol/ug DNA in transgenic mice, compared to only $29-74 \mathrm{fmol} / \mathrm{mg}$ protein or $0.5-0.8 \mathrm{fmol} / \mathrm{ug}$ DNA in nontransgenic mice, an increase of about 100 fold and a higher level of 06AT expression than ever reported in endogenous tissies of any species. These mice should establish whether high levels of the 06AT DNA repair enzyme protects thymic lymphocytes from the development of nitrosourea-induced lymphoma/leukemia and could provide insight into the mechanism and prevention of human secondary leukemias. 
Expression of DNA excision repair genes in human tumor cell lines in relation to drug resistance. Johan Hansson and Stig Linder, Department of General Oncology, Radiumhemet, Karolinska Hospital, S-104 01 Stockholm, Sweden.

Resistance to cytostatic drugs is the major problem encountered in chemotherapy of malignant diseases. Several of the most active and frequently used cytostatic agents, such as the bifunctional alkylating agents and the platinum derivatives, cause DNA lesions that are repaired by nucleotide excision repair. Differences in DNA excision repair capacity may contribute to resistance of human tumor cells to such drugs. We are at present studying the expression of the human DNA nucleotide excision repair genes ERCC-1 and ERCC-3/XPB-C in human tumor cell lines with different sensitivities to DNA damaging cytostatic drugs. Materials and methods: DNA and RNA is extracted from cultured human tumor cell lines. Analyses. of the amounts of specific mRNAs are made with Northern blots, and analyses of gene amplification with Southern blots. Probes for the ERCC-1 and ERCC-3/XPB-C genes were made from vectors. containing complete CDNA inserts, which were generously donated by Dr. J.H.J. Hoeijmakers 1,2. Drug sensitivities of tumor cell lines are de' srmined by clonogenic assays.

Besults: We have measured the sensitivities of several human tumor cell lines to bifunctional alkylating agents (melphalan and nitrogen mustard) and to cisplatin. In initial experiments we have been able to detect varying levels of expression of ERCC-1 and ERCC-3/XPB-C MRNA in human melanoma and lung cancer cell lines. Further studies are under way to determine whether the expression of the excision repair genes is related to differences in drug sensitivity.

Cenclusion: Expression of DNA excision repair genes can be detected in human tumor cell lines. Further investigations are performed to relate drug sensitivity to repair enzyme expression. The present study is the first phase of a larger investigation of the possible importance of differences in DNA excision repair for the response of human tumors to clinical chemotherapy. Beferences:

1. van Duin M. ot al. Cell, 44: 913-923, 1986

2. Weeda G. et al. Cell, 62: 777-791, 1990 
Cellular Responses to Environmental DNA Damage

Variation in ADP-ribose Transferase Activities in Human Monomuclear Leukocytes (HMIL) Jennifer J. Hu, Marianne Berwick, Neil Dubin, *July Powell, *Ronald W. Pero, and George C. Roush. Cancer Prevention Research Institute, NNew York University Medical Center, New York, NY.

Previous studies by different laboratories have suggested that human NAD-dependent ADPribose transferase (ADPRT) is involved in a variety of important biological functions: DNA replication, DNA repair, cell transformation, and differentiation. DNA excision repair involves several enzymes, such as endonuclease, exonuclease, polymerase and ligase activities; ADPRT also plays a role among these. Quantitative estimates of ADPRT activities can be used as an endpoint for assessing oxidatively induced DNA damage and for assessing DNA repair modulated by oxidant status. The measurement of ADPRT activity induced by hydrogen peroxide in human monomuclear leukocytes (FMILs) has been implicated in cancer risk assessment. Decreased ADPRT activities have been associated with cancer of the colon, lung and breast. Our laboratory has focused its application on human risk assessment and possible intermediate biomarkers for cancer intervention studies. We have studied the factors which may contribute to inter-individual variation in ADPRT activities. Preliminary data suggest that interindividual variation of ADPRT activities is closely correlated with the difference from HMIL but not from the plasma; however, plasma contributes some variation to the enzyme assay. Whether the factors present in HMLs or plasma may reflect cancer susceptibility requires further investigation. We have also evaluated a more direct measurement of ADPRT by stimulating the cells with a short double stranded oligonucleotide, namely EcoRI linker. The newly developed assay can eliminate the problem of an individual differential responses to $\mathrm{H}_{2} \mathrm{O}_{2}$ due to varying levels of endogenous antioxidant systems (eg. catalase, and cellular peroxidases). Preliminary results have demonstrated a 2-3 fold difference in ADPRT activities among normal individuals. Whether this variation is important in cancer susceptibility is under investigation. The comparison of ADPRT activities measured by the newly developed method as opposed to the routing measurement by $\mathrm{H}_{2} \mathrm{O}_{2}$ activation should be useful in determining which is the more valuable biomarker for breast cancer susceptibility. 


\section{CELlular Responses to enVironmental dNA DAMAge}

Investigation of the role of DNA repair in the cisplatin resistance phenotype of two human neuroblastoma cell lines.

Christine M. Irelanda, Sally M. Pittmana, Deborah Strickland ${ }^{a}$ and Louise H. Lutzeb.

a Children's Leukaemia and Cancer Research Unit, Prince of Wales Children's Hospital, Randwick 2031 NSW, Australia.

b Laboratory of Radiobiology and Environmental Health, University of Califomia, San Franciso, CA, 94143 USA.

It is generally accepted that the cytotoxicity of the anti-tumour agent cis-diammine dichloroplatinum (II) (cisplatin) results from binding to cellular DNA with attendant interference in transcription and replication. Continued cell survival is thus dependent on recognition and efficient repair of the lesions. Several lines of eviflence suggest a role for increased repair of DNA damage in the development of acquired resistance to cisplatin, including hypersensitivity to the drug in repair-deficient lines and enhanced expression, in cisplatin resistant cells, of genes putatively involved in DNA repair such as DNA polymerases $\alpha$ and $\beta$. To date, studies on the relationship between DNA repair capacity and cisplatin resistance have been performed in cells or cell lines derived from tumours in adults. In contrast, little is known of comparable processes in paediatric malignancies such as neuroblastoma, in which cisplatin is an important component of treatment regimens.

We have derived two unique cisplatin-resistant neuroblastoma cell lines with the aim of investigating the phenotypic and molecular characteristics of DNA repair processes in cell lines derived from this tumour type. The IMR-32 and SK-N-SH cell lines have been treated with escalating doses of cisplatin over a two year period. Cytotoxicity studies performed using the microculture tetrazolium ar sy (NTA) demonstrate that the IMR32/CP.18 and SK-N-SH/CP.15 lines are significinitly more resistant (five fold and three fold, respectively) to cisplatin than their parent cell lines. The parental SK-N-SH line is intrinsically seventeen-fold more resistant to cisplatin than IMR-32. Cytogenetic analysis revealed abnormalities of chromosome $\# 11$ in association with the resistant phenotype. The breakpoint in the SK-N-SH/CP.15 cells coincides with the mapped position of the glutathione-S-transferase 3 gene (11q13-qter), which codes for an enzyme implicated in detoxifying cisplatin. Both cisplatin resistant lines were cross-resistant to aphidicolin, which is known to inhibit DNA polymerase a, a finding suggestive of involvement of this enzyme in the resistant phenotype. The effect of damage induced by cisplatin treatment on replication and mutgenesis in the shuttle vector pZ189 is being examined using both parental and resistant neuroblastoma cell lines. Undamaged pZ189 has been successfully transfected into all lines using ele roporation. Preliminary results using the parent lines indicate a dose-dependent inhibitun of replication, and an increase in the observed mutation frequency following cisplatin treatment of the vector. Studies are currently in progress to examine the possible involvement of the enzymes glutathione-Stransferase 3 and DNA polymerase $\alpha$ in the drug resistance phenotype of these cells, and to determine, using the shuttle vector assay, the relative DNA repair capabilities of the drug sensitive and resistant populations. 
"Collular Rosponses to Envirormental Dun Damage"

Evidence for Defective Repair of Apurinic/Apyrimidinic Sites in Alzhoimer's Disease and swyotrophic Lateral sclerosis. N.C. Iambert, H.-R. Nuo, N.I. Ramos, G.J. Trangrilis, A.O. Okorodudu, M.8. Tan and X.K. Lambert. Dapartment of

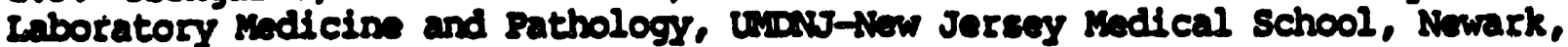
INew Jersey 07103

Wh examinad lymphoblastoid cells derived frcm patients with sporadic (2 cases) (SND) and familial (3 cases) (IAD) Alabeimer's disease for sensitivity to exposure to 0.3 to $2.25 \mathrm{myl}$ methyl methanesulfonate (buss), which produces apurinic/apyrimidinic (AP) sites in DN. Both SAD cell lines showed decreased viability and less than 208 of normal levels of unschechuled DNA synthesis (UDS) over the entire range of doses of kiss; IAD cells showed a lesser, dose-depandent deficiency in their response to sus. By contrast, no Nizheimer's cell Iine showed increased sensitivity to bleomycin, which produces strand breaks in DNM. Introduction, by electroporation, of either of two normal human chronatin-associated AP lyase complexes, PIs 9.2 and 9.8, restored Ievels of WDS in riss treated SAD and FAD cells to normal levels. The complex, pI 9.2, was are effective than the couplex, pI 9.8, in producing this effect.

Treatment of lyuphoblastoid cells derived from two typical (1.e.. elderly onset) cases of sporadle amyotrophic lateral sclerosis (ALS) and from two typical cases of AIS from an Ars-prone family with shs revealed only relatively subtle increases in $108 s$ of viability, as measured by trypan blue exclusion, requiring normalization of data for differences to be readily appreciated. Bowever, all four Ars cell lines failed to decrease their rates of replicative DN synthesis and of cell division following wys exposure, whereas in lymphoblastoid cells derived ercm normal subjects both rates decreased markedly. Thus all four ALS lyuphoblastoid cells showed marked damage-resistant un synthesis (DRDS) following exposure to MYS. A fifth lymphoblastoid cell 1ine, derived from a patient with onset of AIS in the fourth decade (atypical AIs), failed to show any of thyse abnormalities following rys exposure. Pulsing these Ars cell lines with (B)-thymidine following Ius exposure and subsequent processing of cells by autoradiography confirmed that the four Ars cell Iines showing DiDS were contiming to synthesize DNA at rates similar to those of untreated cells following exposure to Mis, whereas normal lymphoblastold cells showd reduced replicative DNA synthesis following wiS exposure as determined by autoradiography. In addition, normal lymphoblastoid cells not in 8 phase thowed lower levels of uDs following viss exposure, whereas in all four typical AIs cell lines uns was reduced. Introduction, by electroporation, of either of the two normal DN AP Iyase complexes Into these Aus cells rechced their rates of replicative DN synthesis and raised their us to normal levels following yis exposure. In contrast to results obtained with ALS lymphoblastoid cell Iinew, however, the complex pI 9.8, was more effective than the complex, PI 9.2. in restoring these responses of ALS cells to vars exposure to normal.

since AP sites in DN are selectively generated by wh exposure, these renults indicate that certain neurodegenerative diseases may be associated with defective repair of AP sites in cellular DN. These deficiencies appear to differ between Alaheimer's disease and ArS and between cell lines of different Individuals affected by these diseases. Whether these deficiencies are che to abnormal proteins in the chromatin-associated AP lyase complexes wh have isolated is currently under investigation. 
Cellular Responses to Environmental DNA Damage

Heterogeneity of DNA Double-strand Break Induction and Repair in Human Iymphocytes Entails Age and Gender Differences. Peter J. Mayer, Christopher s. Iange?, Matthews 0 . Bradiey and warren $w$. Nichols

'Department of Radiation Oncology, Box 1212, suny Health Science Fenter at Brookdyn, 450 Clarkson Ave, Brooklyn, NY 11203, USA

Synthecell Corp., 9620 Medical Ctr. Dr.. Rockville, MD 20850, USA Department of Safety Assessment, Merck, Sharp Dohme Research. Iaboratories, West Point, PA 19486, USA

Individual differences in the induction and repair of DNA were shown to be age-related in unstimulated human lymphocytes (Mayer, Iange, Bradley, and Nichols 1989,1990$)$ " In that work peripheral lymphocytes isolated from whole blood donated by 20 normal, healthy subjects aged 23-78 yr, were $x$-irradiated ( 30 Gy) on ice and incubated at $37^{\circ} \mathrm{C}$ for repair times of 15,30 , and $120 \mathrm{~min}$, and neutral Eilter elution (PH 9.6) was used to assay DNA damage (nominally DSBS) induction and the completeness of repair (DSB rejoining). Further analysis reveals that the decrease in DSB rejoining appears to be more pronounced in older women than in: older men (and may begin after age $65 \mathrm{yr}$ ). Moreover the reported age-related decline in DSB induction occurs more rapidly (by a. factor of $\mathrm{ag}$. 2) in women than in men. We had previously demonstrated that, independently of in vivo age, cel2s with lower radiosensitivity (i.c., lesser DSB induction) appear to be 2 ese repair-proficient (Mayer et al. 2990). The present analysis reveals a gender-specific pattern in this correlation between extent of DSBB induced and percentage of DSBs rejoined: at comparable levels: of DSB induction, cells from men rejoin a higher percentage of DSBs than cells from women. This preliminary study suggests the following hypothesis: age-related DSB effects (i.e., Induction and? rejoining) are due to changes in chromatin structure and males are less sensitive than females to the influence which age-related alterations in chromatin exert on DNA damage and repair.

References:

Mayer, P.J., Lange, C.S., Bradley, M.O. and Nichols, W.W. . 1989, Age-dependent decline in rejoining of $x-r a y-i n d u c e d ~ D N A ~ d o u b l e-$ strand breaks in normal human iymphocytes. Uutation Research 229: 95-100.

Mayer, P.J., Iange, C.S., Bradley, M.O., and Nichols, W. H. , 1990, Rejoining of $\mathrm{x}$-ray-induced DNA double-strand breaks declines in unstimulated human iymphocytes aging in yivo. In Biomedical Advances in Aging, edited by A.L. Goldstein (New York: Plenum), Pp. 195-206.

This work was supported in part by the Merck Institute for Therapeut $C^{C}$ Research, the Harold $\sigma$. and Leila $Y$. Mathers Charitable Foundation, and Blomedical Research Support Grant $2507 R R 0540228$ Irom U.S.P.H.S. 
Proliferin Transcript Induction by structurally Diverse Tumour promoters. Graic I.J. Parfett: Division of Environmental and Occupational Toxicology, Health Protection Branch, Bealth and Welfare Canada; Environmental Health Centre, Tunney's Pasture, ottawa, Ontario, Canada KLA OL2.

several environmental contaminants promote morphological transformation in C3HIOT1/2 cell cultures. It is not known if these chemicals induce those genes characterized as being regulated by well-studied phorbol ester tumour promoters, such as TPA. In an investigation designed to determine whether there is any significant overlap between TPA-regulated and chemicallyregulated gene expression, it was discovered that cytoplasmic mRNA levels of the TPA- and growth factor-responsive proliferin gene family were increased up to 40 - fold following 3 to $5 \mathrm{~h}$ exposure to those chemicals promoting the appearance of foci in monolayer C3HIOTI/2 cultures. Promoters of transformation eliciting induction were: 1) the phenolics anthralin and butylated hydroxytoluene, 2) the sulfhydryl reactor lodoacetic acid and 3) the detergent Tween 60 . In contrast, the nonpromoters methanol and formic acid did not elevate proliferin transcript levels. Much lower, physiologlcally relevant concentrations of the promoters were effective inducers of proliferin when the exposure perlod was increased. Proliferin mRNA was also induced in C3H1OT1/2 cells by various polycyclic aromatic hydrocarbons (PAi), nickel chloride, benzoyl peroxide and tert-butyl hydroperoxide, which are chemicals that have been identifled as promoters of tumourigenesis and morphological transformation in animals and/or other cell lines. Several TPAresponsive genes were not induced by treatment with PAH. The proliferin gene family is hypothesized to be especially sensitive to derangement of signal transduction mechanisms or chromatin structure within treated cells. The results suggest that the response of proliferin mRNA, following chemical exposure of C3H10T1/2 cells, might be employed as a marker predicting the potential for promotion of focus formation in an in vitro morphological transformation assay. 


\section{Cellular Responses to Environmental DNA Damage}

\section{Platinum-DNA Damage in Leukocyte DNA is Directly Related to the Magnitude of Tumor Response in Patients Receiving Carboplatin and Cisplatin} Chemotherapy. Ricardo J. Parker, Justine A. Vionnet, Annette Bicher, Robert Tarone, and Eddie Reed National Cancer Institute, Bethesda, Maryland 20892.

Platinum-DNA adduct level in leukocytes of human cancer patients receiving platinum drug therapy is directly related to disease response. Recently, this correlation was demonstrated in a blinded study of a 21 patient cohor comprised of is different tumor types who received carboplatin (day 1) and cisplatin (day 3). This study demonstrated that the relationship between adduet level and disease response is independent of tumor histology (Parker et al, Carcinogenesis 12:1253-1258, 1991). Here, we update our report to include all evaluable patients to date on this phase I trial. This includes 30 individuals and 19 different types of tumors. Atomic absorption spectrometry with Zeeman background correction was used to measure DNA-bound platinum in leukocyte DNA 24 hours after drug therapy during cycle 1 (C1) and cycle 2 (C2). For each of these two cycles, most patients developed measurable levels of adduct after carboplatin, and adduct levels increased further after cisplatin, often in a supra-additive fashion. Whereas total mg dose levels varied by less than 2-fold, individual adduct levels differed by more than 102 after $\mathbf{C l}$ and after $\mathrm{C2}$ of therapy. In the subset of patients who were studied on each of $\mathbf{3}$ days in both cycle 1 and cycle 2, adduct accumulation and persistence were prominent features of the DNA adduct profile. Disease response analyses of 27 evaluable patients showed that adduct levels were higher in patients with favorable response status. Median adduct levels after the first dose of carboplatin were higher in 7 responders ( $42.3 \mathrm{fmol}$ Pt/Mg DNA) than in 6 stable patients (21.2 fmol Pt/Mg DNA) whose adduct levels were higher than 14 patients with progressive disease (14.6 fmol Pt/ $/ \mathrm{g} D \mathrm{DN}$ ); Jonckheere-Terpstra (rank test for trend) two-sided $p=0.011$. Summary stratified analyses of all days studied for adduct level show that adduct levels were consistently higher in responders, with a two-sided p value of 0.0018 . These data indicate that the correlation between the levels of platinum-DNA adduct and disease response is independent of tumor type, and that the magnitude of the tumor response is directly related to leukocyte adduct level. This suggests that clinical resistance to DNA damaging agents may be primarily dependent upon pharmacogenetic processes, and may be independent of the process of conversion of non-malignant cells to the malignant state. 


\section{Cellular Responses to Environmental DNA Damage}

MEASUREMENT OF ADPRT ACTIVITY IN HUMAN MONONUCLEAR LEUKOCYTES WTTH AND WITHOUT PLASMA. Berwick M, Hu J, Pero R, Roush GC. Cancer Prevention Research Institute, NY, NY 10010

Variations in the DNA repair process could lead to cancer susceptibility in humms. Adenosine diphosphate ribosyl transferase (ADPRT) in human monomuclear leukocytes reflects DNA repair and has been reported as inversely related to cancer $(1,2)$. In a study designed to distinguish the effects of plasma solutions on levels of ADPRT, samples of blood were obtained from 26 women 55 years of age or older with breast cancer, benign breast disease, or with no complaint related to the breast. Standard assays for both activated and constitutive ADPRT were conducted on duplicate samples using both 1 percent and 0 percent plasma. In every instance, the ADPRT at 1\% plasma was higher than the ADPRT at 0\% plasma. The mean of the activated ADPRT at 1\% plasma was 4061 (s.e. 2130), while the mean at $0 \%$ plasma was 2737 (s.e. 2020). Data were then analyzed for inter-individual variation using analysis of variance, calculating the intra-class correlation coefficient (ICC).

Table 1. Inter-individual variation of activated and constiturtive ADPRT in $0 \%$ and $1 \%$ added plasma.

\begin{tabular}{|l|r|r|r|}
\hline \multicolumn{1}{|c|}{ Measure } & ICC & F value & P value \\
\hline Activated ADPRT, 1\% plasmat & $94 \%$ & 38.08 & 0.0001 \\
\hline Constitutive ADPRT, 1\% plasmat & $76 \%$ & 7.50 & 0.0001 \\
\hline Activated ADPRT, 0\% plasma & $98 \%$ & 126.80 & 0.0001 \\
\hline Constitutive ADPRT, 0\% plasma & $87 \%$ & 14.69 & 0.0001 \\
\hline Activated ADPRT plasma effects & $68 \%$ & 5.25 & 0.0001 \\
\hline Constitutive ADPRT plasma effects & $57 \%$ & 3.68 & 0.0001 \\
\hline
\end{tabular}

- This can be understood as the percentage of variation in the ADPRT measure due to differences among persons.

+ This is the measure used in reports in references 1 and 2.

- ADPRT at 1\%-ADPRT at 0\%.

The plasma effect on ADPRT was highly significant statistically. Compared to ADPRT values for either $0 \%$ or $1 \%$ plasma, the plasma effect of ADPRT explained nearly as much of the differences among the 26 participants (e.8., 68\% vs. 98\% and 94\% for activated ADPRT).

While Pero has published data showing that plasma affects ADPRT levels, this is the first time that the effects of plasma on individual differences have been quantitated, suggesting an important plasma effect on this DNA repair enzyme.

(1) Pero RW, Johnson DB, Miller DG \& al. Adenosine diphosphate ribosyl transferase responses to a standardized dose of hydrogen peroxide in mononuclear leukocytes in patients with a diganosis of cancer. Carcinogenesis 1989; 10:1657-64.

(2) Roush GC; Lund-Pero M, Powell J, Pero RW. Family history of cancer and adenosine diphosphate ribosyl transferase (ADPRT). 1990. (unpublished manuscript). 
Activated neutrophils induce unscheduled DNA synthesis in murine B lymphocytes. Siegfried Janz and Emily Shacter, Laboratory of Genetics, National Cancer Institute, National Institutes of Health, Bethesda, MD

Activated neutrophils induce DNA damage in neighboring cells by secreting reactive oxygen compounds into the extracellular milieu. Insufficient repair of this damage can lead to mutations and neoplastic transformation. Conditions: were established to measure the activation of excision repair pathways (stimulated thymidine uptake, unscheduled DNA synthesis,. UDS) in target B lymphocytes exposed to activated neutrophils. Paraffin oil-elicited murine neutrophils were cocultured in serum-free medium with a mouse plasmacytoma cell line $\left(5 \times 10^{5} \mathrm{cells} / \mathrm{ml}\right)$ for $2 \mathrm{~h}$ in the presence of [ $\left.{ }^{3} \mathrm{H}\right]$-thymidine (3H-TdR) and 10 mM hydroxyurea (HU), an inhibitor of replicative DNA synthesis. Cytotoxicity was determined by carrying out assays in the absence of HU. It was found that UDS in the tumor cells was stimulated significantly at effector:target cell ratios of 1:1 to 4:1 when the neutrophils were activated with phorbol myristate acetate. UDS was completely inhibited when catalase was added to remove $\mathrm{H}_{2} \mathrm{O}_{2}$. Under these assay conditions, reagent $\mathrm{H}_{2} \mathrm{O}_{2}$ alone $(2.10 \mu \mathrm{M})$ also induced UDS efficiently. This occurred under conditions of lower cytotoxicity than observed with other UDSinducing agents such as 4-nitroquinoline-1-oxide (4-NQO) or $\gamma$-radiation. Induction of UDS by neutrophils was also examined in primary splenic B " lymphocytes stimulated with lipopolysaccharide. In contrast to the results obtained with the plasmacytoma cell line, induction of UDS in normal B lymphocytes was dependent upon the proliferative and differentiative state of the cells with maximum UDS being observed after $48 \mathrm{~h}$ of culture. Finally, no UDS was observed within the neutrophils themselves, suggesting that these cells are deficient in some repair enzymes. The results demonstrate that an in vitro, excision repair assay can be employed to assess the contribution of different cellular parameters to the repair of neutrophil-induced DNA damage. 
ACQUIRED LOSS OF GLUTATHIONE S-TRANSFERASE Yb2 EXPRESSION DURING PROGRESSION OF HEPATOCELLULAR CANCER IN FISCHER 344 RATS Margaret J. Stalker Trudy E. Kocal and M. Anthony Hayes. Department of Pathology, University of Guelph, Guelph, Ontario, Canada N1G 2W1.

There is accumulating evidence that species and individual susceptibility to a variety of carcinogens is directly related to the ability to detoxify DNA-damaging metabolites. Glutathione S-transferases (GSTs) are an important group of multifunctional isoenzymes which catalyze the conjugation of glutathione to a variety of exogenous and endogenously produced carcinogenic compounds, and form a major component of the normal cytoprotective system. In humans, genetic deficiency of a GST $\mu$ class isoenzyme subunit has been linked to increased risk for lung, stomach and colon cancer. We have hypothesized that in species which are constitutively resistant to particular carcinogens by virtue of their GST phenotype, loss of this resistance mechanism might render preneoplastic cells more susceptible to DNA damage and facilitate malignant progression. To address this question, we examined the expression of immunoreactive GST subunits in altered foci and liver neoplasms produced in male Fischer 344 rats at two time periods after initation by a modified Solt-Farber protocol. At 6 months after initiation, histological sections of altered foci and persistant nodules displayed increased staining for GST subunits $\mathrm{Yf}, \mathrm{Ya}, \mathrm{Yb} 1$ and Yc relative to surrounding liver, as determined by peroxidase anti-peroxidase (PAP) immunohistochemistry using polyclonal rabbit antibodies to the major GST subunits. However, while most altered foci exhibited little change in GST Yb2 subunit expression, 4\% of the Yf positive foci and nodules were partially or completely deficient in Yb2 expression. At 12 months post-initiation, the great majority of grossly visible hepatocellular adenomas and carcinomas retained induced expression of GST subunits $\mathrm{Yf}, \mathrm{Ya}, \mathrm{Yb1}$ and $\mathrm{Yc}$, but $83 \%$ of the advanced tumors were deficient in GST Yb2 expression. This pattern of GST subunit expression was also found in lung metastases of hepatocellular carcinomas. While the mechanism and role of the reduction or loss of this $\mu$ class GST Yb2 subunit during malignant progression are unknown, it might be important in increasing susceptibility of some preneoplastic populations of hepatocytes to further DNA damage by environmental or endogenous chemicals such as 4-hydroxyalkenals, highly cytotoxic and mutagenic products of lipid peroxidation, that are normally detoxified by GST isoenzymes containing this subunit. 


\section{Cellular Responses to Environmental DNA Damage}

Is mutation time, rather than generation, dependent in developing tumors? BernardSS Strauss, ICRF Clare Hall Laboratories, U.K. and Dept. of Molecular Genetics and Cell Biology. The University of Chicago

The idea that point mutation is central to carcinogenesis is an old one. Until recently however, specific genetic changes had not been observed in tumors and the keystone of the belief that genetic change is central to carcinogenesis was what appeared to be a close correlation between mutagenicity and carcinogenicity. The situation is almost completely reversed today. The class of non-mutagenic carcinogens has been shown to be very large. On the other hand, so many genetic changes have been observed in individual cancers that the measured mutation rates in somatic. cells seem unable to account for their appearance. For example, single tumors may contain both ras and 053 point mutations along with chromosomal changes. Consequently, it is plausible to postulate special hypermutability mechanisms in tumors. However, it may be that no special mechanisms are required, but rather that the estimates of mutation rate so far reported in somatic mammalian cells and for neutral mutations in the genome do not reflect the rates in developing tumors. Such measurements most often use Luria-Delbruck conditions to estimate preexisting mutations. The unit in which mutation is measured is the cell generation. Such conditions are not applicable to the situation in tumors. Rather, developing tumors are similar to Escherichia coli kept under selective conditions as described by Shapiro, by Caims ot al., and by Hall. Mutation in such cases is time, rather than replication dependent, and continues in the absence of cell proliferation. The mutations observed in bacteria result in a selective advantage and the particular mutations observed in tumors also appear to give the cells in which they occur a selective advantage. The mechanism by which these time-dependent mutations occur is unknown, but the specificity of the mutations observed in tumors indicates that some are induced as a result of alterations in the DNA. It is not yet clear how the rate of mutation is to be expressed in quiescent cells held under selective conditions.

The support of a Fogarty Senior International Fellowship from the National Institutes of Health is gratefully acknowledged. 
The Contribution of Aging to DNA Repair and to Basal Call Carcinoma When Studied in over 400 Human Subjects. Q.Wei12, M. Hedayatil. E. Farmer, G. Matanoskj and $2 L$ Grossmani. 'Departments of Biochemistry and 2Epldemiology, The Johns Hopkins University School of Hygiene and Public Health and J Department of Dermatology. Johns Hoplins School of Medicine, Baltimore, MD 21205

A method for measuring DNA excision repair in response to ultraviolet imadiation and chemical-induced DNA damage has been deveisped, validated, and "field-tested in cultured human lymphocytes. The methodology is amenable to population-based screening and should faciltate tuture epidemiologic studies seeking to investigate associations between DNA repair proficiency and cancer susceptiblity.

For the assay, damaged non-replicating recombinant plasmid DNA harboring a chloramphonicol acotyltransforase (cai) reporter gene is introduced into lymphocytes using a DEAE-dextran/DNA complex short-term transfection conditions. Excision repair of the damaged bacterial cat gene is monitored proportionately as a function of reactivated CAT enzyme activity following a $40 \mathrm{~h}$ repair/expression incubation period.

The validity of the approach was indicated by the assay's ablity to discriminate XP virus-transformed lymphocyte cell lines of both severe (complementation groups $A$ and $D$ and moderate (complementation group $C$ ) excision: repair deficiencies from repair-proficient cell lines. Similar results were observed when a mitogen-stimulated peripheral blood lymphocyte (PBL) culture from an XP-A (homozygous) patient was assayed concurrently with mitogen stimulated PBLS obtained from healthy individuals. The sensitivity of the assay was demonstrated with PBLs from putative heterozygotes. (Athas, W.F., Hedayatl, M.A., Matanoski , G.M., Farmer, E.R., and Grossman, L. (Cancer Research, 50, in press)

Adaption of this DNA repair assay of UV-damaged DNA as a field-test in a group of 454 subjects in which an approximate equal distribution of basal coll carcinoma (BCC) patients and cancer-iree controls were examined. It was found that the DNA repair capacity of the controls declined linearly $32 \%$ during a thirty year increase in age, whereas the DNA repair capacity of BCC patients remained essentially constant over this same period of aging. Young BCC patients showed the same lovel of repair as control patients thity years their senior. It is suggested that a causal factor in basal cell carcinoma may be the premature "aging" of such an individual's DNA repair capacity. 

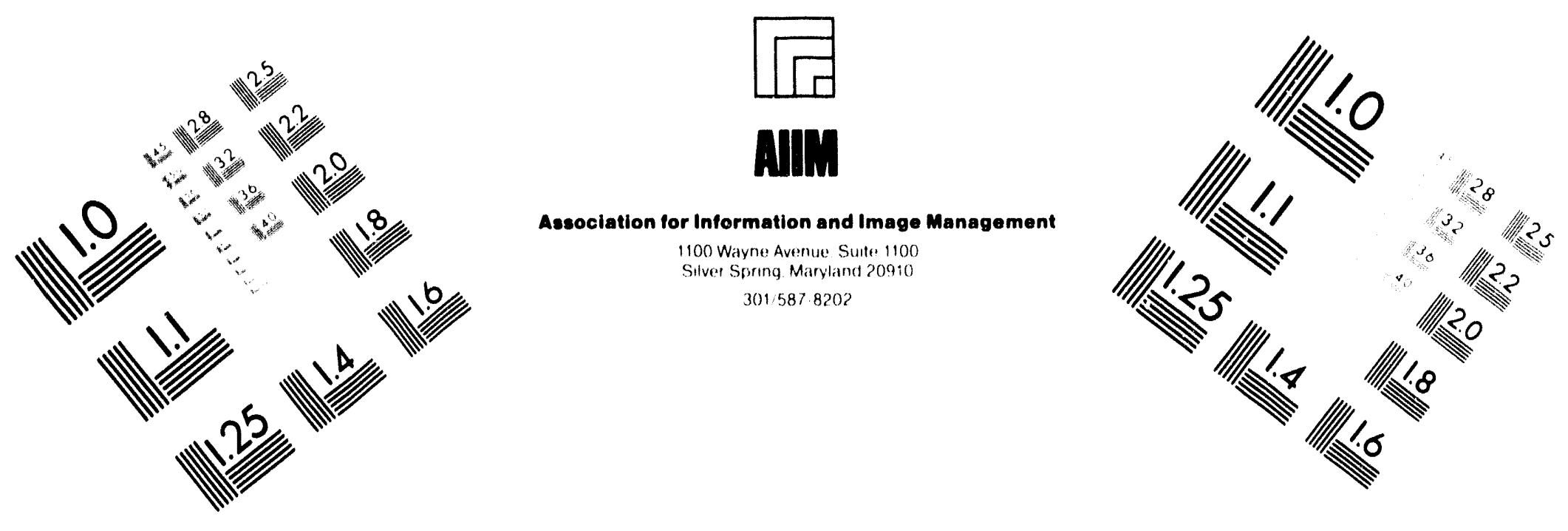

\section{Centimeter}

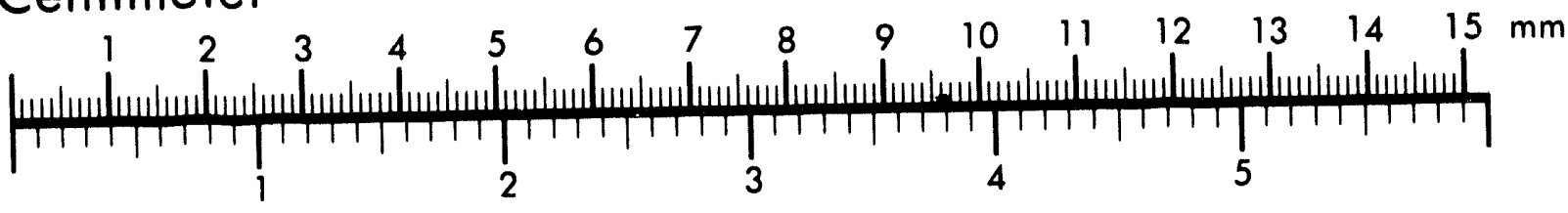
Inches
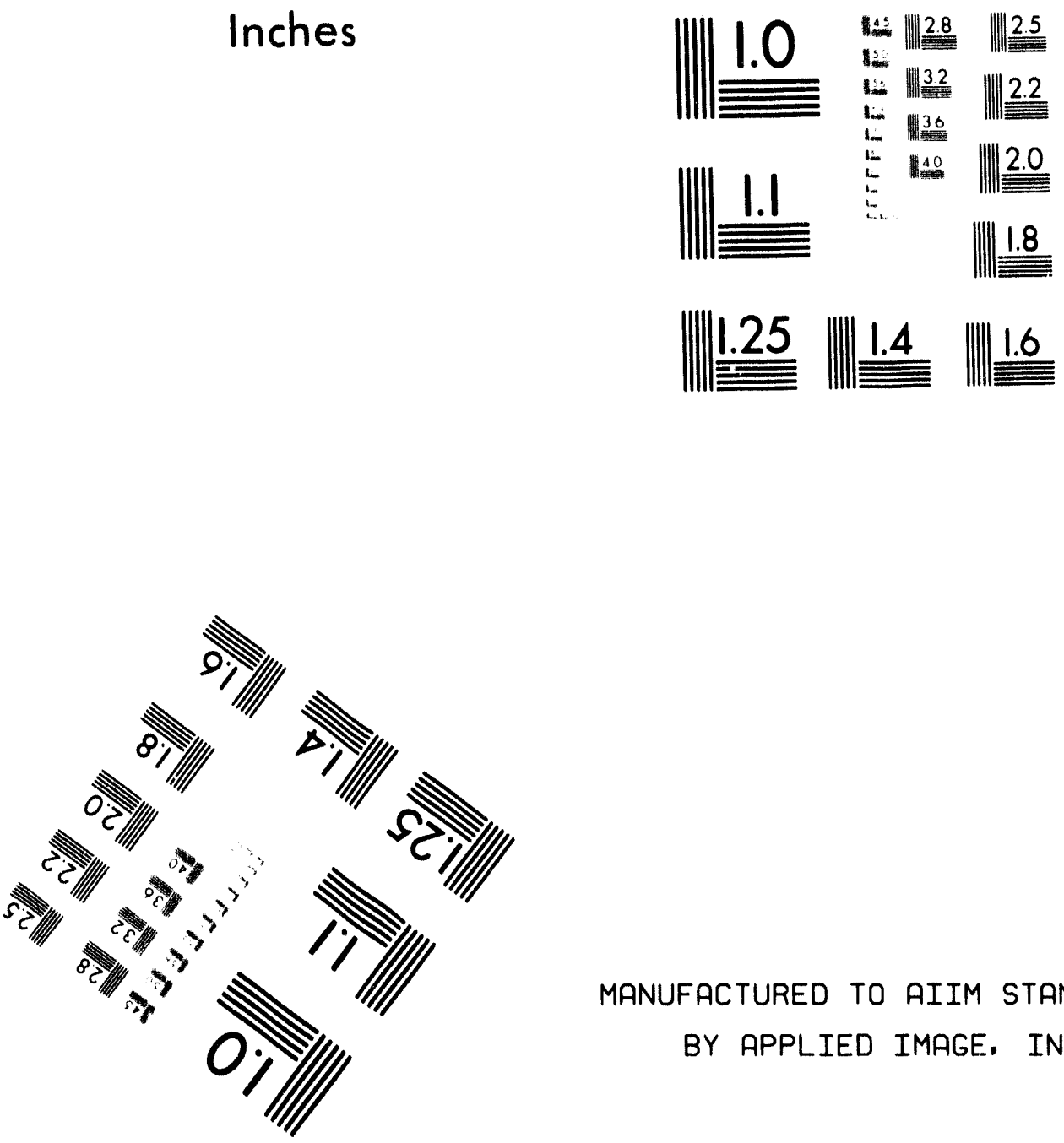

MANUFACTURED TO AIIM STANDARDS

BY APPLIED IMAGE, INC.

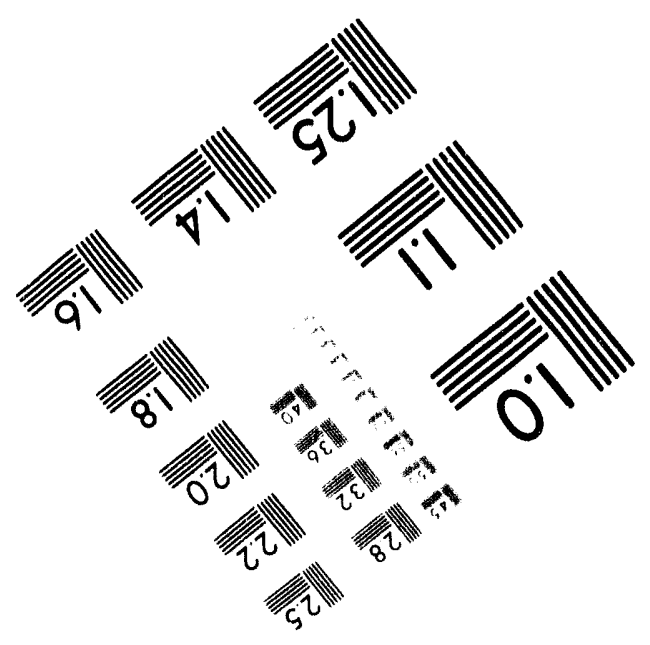




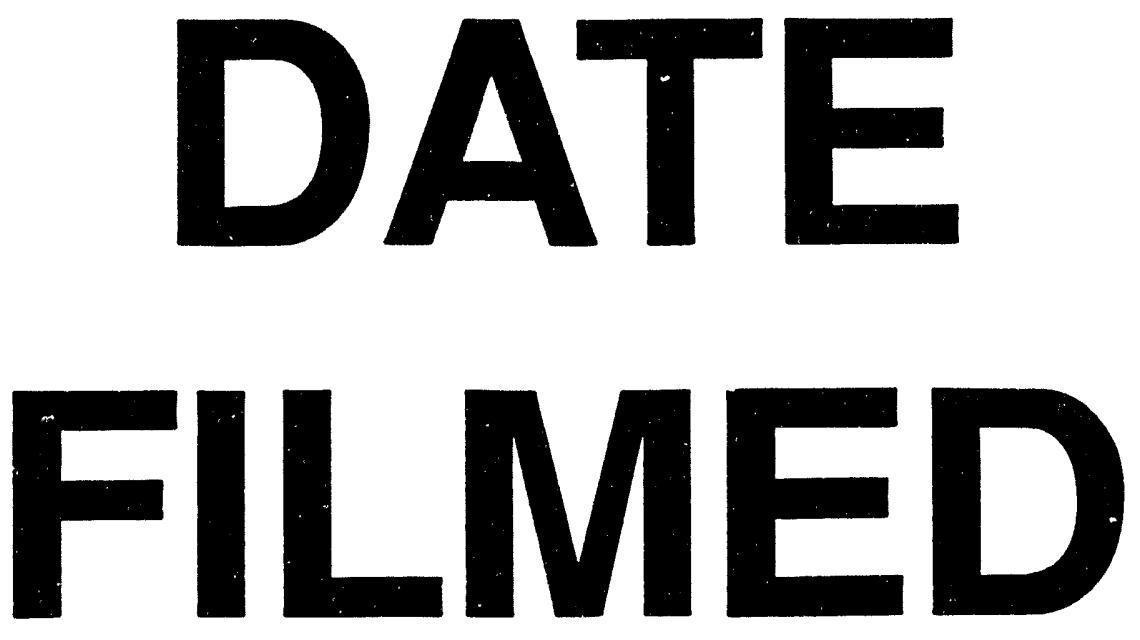

$12 / 15 / 94$
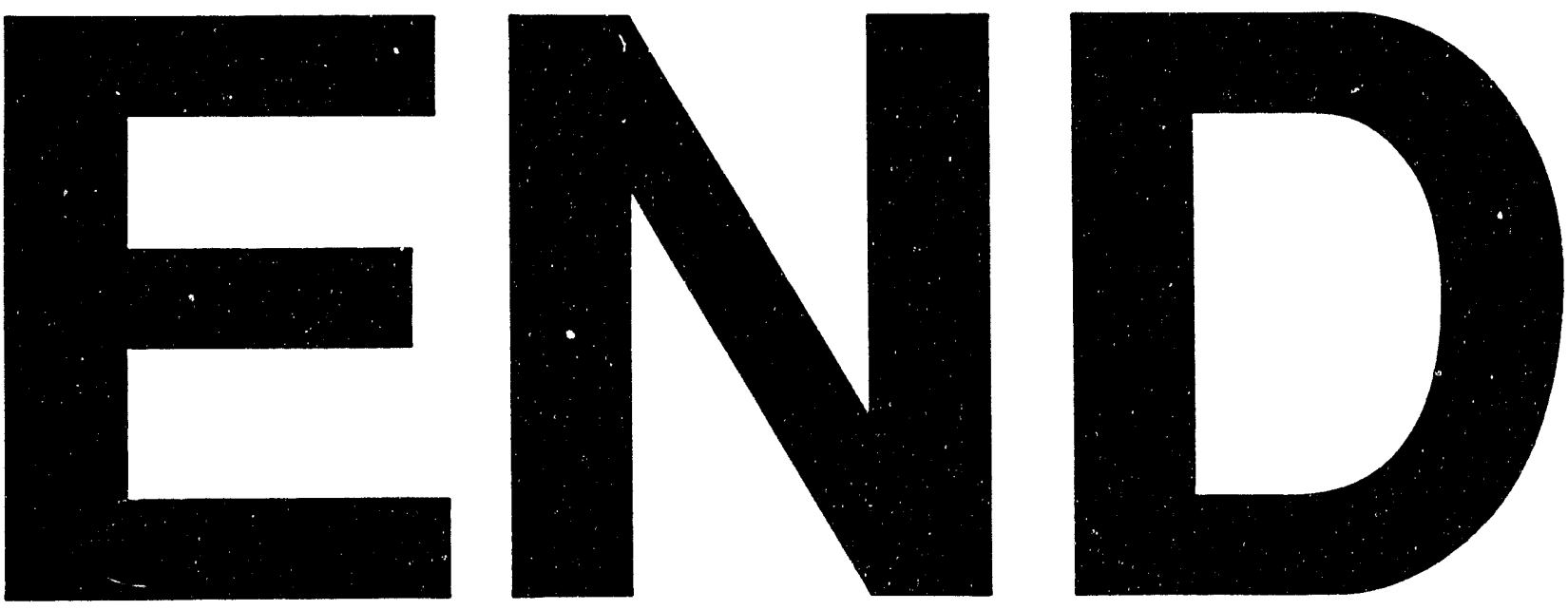